US Army Corps of Engineers.

Prepared for the U.S. Army Corps of Engineers, Portland District

Under an Interagency Agreement with the U.S. Department of Energy

Contract DE-AC05-76RL01830

\title{
Evaluating Cumulative Ecosystem Response to Restoration Projects in the Lower Columbia River and Estuary, 2009
}

\section{FINAL ANNUAL REPORT}

Prepared by:

Pacific Northwest National Laboratory National Marine Fisheries Service Columbia River Estuary Study Taskforce University of Washington

October 2010

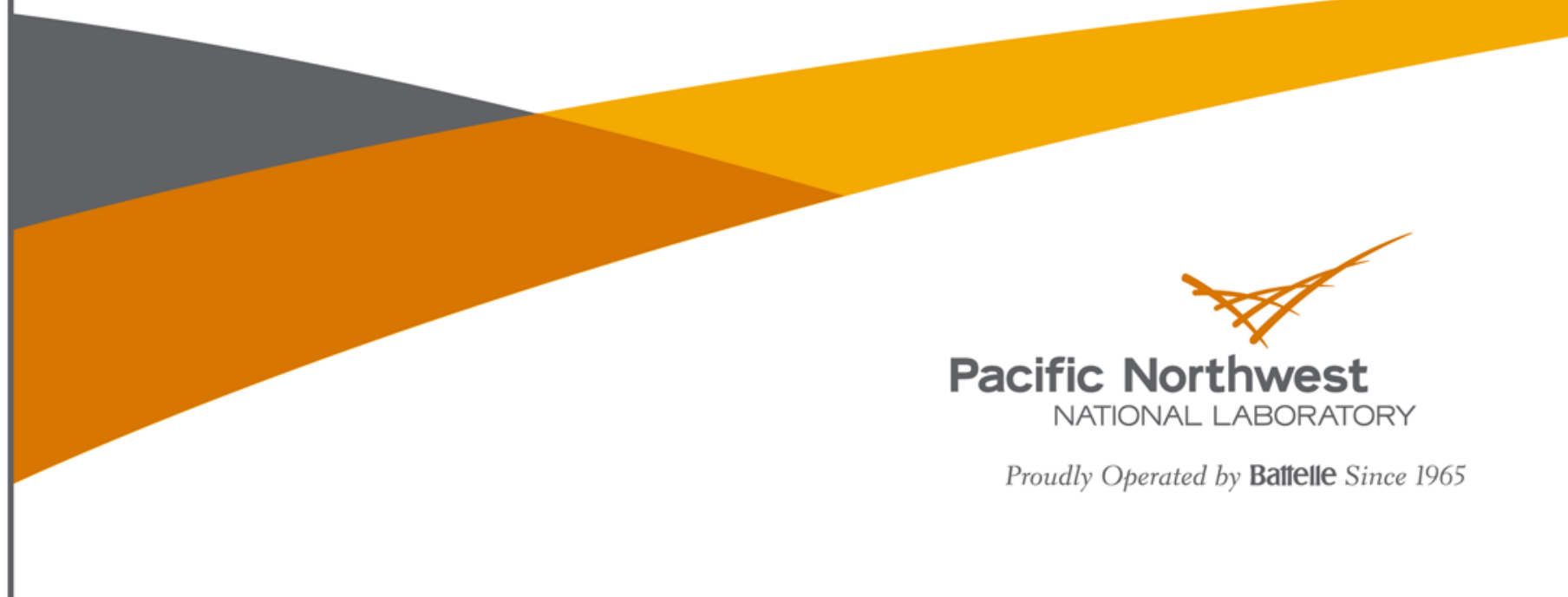




\title{
DISCLAIMER
}

This report was prepared as an account of work sponsored by an agency of the United States Government. Neither the United States Government nor any agency thereof, nor Battelle Memorial Institute, nor any of their employees, makes any warranty, express or implied, or assumes any legal liability or responsibility for the accuracy, completeness, or usefulness of any information, apparatus, product, or process disclosed, or represents that its use would not infringe privately owned rights. Reference herein to any specific commercial product, process, or service by trade name, trademark, manufacturer, or otherwise does not necessarily constitute or imply its endorsement, recommendation, or favoring by the United States Government or any agency thereof, or Battelle Memorial Institute. The views and opinions of authors expressed herein do not necessarily state or reflect those of the United States Government or any agency thereof.

\author{
PACIFIC NORTHWEST NATIONAL LABORATORY \\ operated by \\ BATTELLE \\ for the \\ UNITED STATES DEPARTMENT OF ENERGY \\ under Contract DE-AC05-76RL01830
}

Printed in the United States of America

Available to DOE and DOE contractors from the

Office of Scientific and Technical Information,

P.O. Box 62, Oak Ridge, TN 37831-0062;

ph: (865) 576-8401

fax: $(865) 576-5728$

email: reports@adonis.osti.gov

\footnotetext{
Available to the public from the National Technical Information Service, U.S. Department of Commerce, 5285 Port Royal Rd., Springfield, VA 22161 ph: (800) 553-6847 fax: $(703) 605-6900$

email: orders@ntis.fedworld.gov

online ordering: http://www.ntis.gov/ordering.htm
}

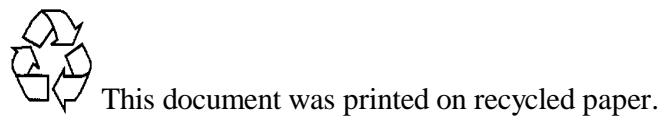


PNNL-19440

\section{Evaluating Cumulative Ecosystem Response to Restoration Projects in the Lower Columbia River and Estuary, 2009}

Edited by Gary E. Johnson ${ }^{1}$ and Heida L. Diefenderfer ${ }^{1}$

$\begin{array}{ll}\text { Amy B. Borde }^{1} & \text { Amanda Bryson } \\ \text { April Cameron }^{6} & \text { André M. Coleman }^{1} \\ \text { Catherine Corbett }^{2} & \text { Earl M. Dawley }^{3} \\ \text { Blaine D. Ebberts }^{4} & \text { Ron Kauffman }^{1} \\ \text { G. Curtis Roegner }^{5} & \text { Micah T. Russell }^{6} \\ \text { April Silva }^{6} & \text { John R. Skalski }^{7} \\ \text { Ronald M. Thom }^{1} & \text { John Vavrinec III }^{1} \\ \text { Dana Woodruff }^{1} & \text { Shon A. Zimmerman }\end{array}$

FINAL ANNUAL REPORT

October 2010

Prepared for the

U.S. Army Corps of Engineers, Portland District

Under a Government Order with the U.S. Department of Energy

Contract DE-AC05-76RL01830

Prepared by:

Pacific Northwest National Laboratory, Marine Sciences Laboratory National Marine Fisheries Service, Pt. Adams Biological Field Station Columbia River Estuary Study Taskforce University of Washington, Columbia Basin Research

\footnotetext{
${ }^{1}$ Pacific Northwest National Laboratory, Richland, Washington

${ }^{2}$ Lower Columbia River Estuary Partnership, Portland, Oregon

${ }^{3}$ National Marine Fisheries Service (retired), Astoria, Oregon

${ }^{4}$ U.S. Army Corps of Engineers, Portland District, Portland, Oregon

${ }^{5}$ NOAA Fisheries, Hammond, Oregon

${ }^{6}$ Columbia River Estuary Study Taskforce, Astoria, Oregon

${ }^{7}$ University of Washington, Seattle, Washington
} 



\section{Executive Summary}

This is the sixth annual report of a 7-year project (2004 through 2010) to evaluate the cumulative effects of habitat restoration actions in the lower Columbia River and estuary (LCRE). The project, called the Cumulative Effects Study, is being conducted for the U.S. Army Corps of Engineers Portland District (USACE) by the Marine Sciences Laboratory of the Pacific Northwest National Laboratory (PNNL), the Pt. Adams Biological Field Station of the National Marine Fisheries Service (NMFS), the Columbia River Estuary Study Taskforce (CREST), and the University of Washington.

The goal of the Cumulative Effects Study is to develop a methodology for evaluating the cumulative effects of multiple habitat restoration projects intended to benefit ecosystems supporting juvenile salmonids in the 235-km-long LCRE. Literature review in 2004 revealed no existing methods for such an evaluation and suggested that cumulative effects could be additive or synergistic. From 2005 through 2009, annual field research involved intensive, comparative studies paired by habitat type (tidal swamp versus marsh), trajectory (restoration versus reference site), and restoration action (tide-gate replacement vs. culvert replacement vs. dike breach).

During 2009, the specific objectives for the Cumulative Effects Study were as follows:

1. Support the cumulative effects assessment at pilot and estuary-wide scales through field work to document selected higher-order metrics, develop a time series, and expand the spatial and temporal diversity of sites for cumulative effects analysis, as follows:

a. At Crims Island, Kandoll Farm, and Vera Slough restoration and reference sites, sample all core metrics.

b. At selected historical breach and created sites, sample hydrology, morphology, vegetation, and fish abundance.

c. Perform an intensive material-exchange study at the Kandoll Farm culvert over 48-hr periods during a spring- and a neap-tide series.

2. Test estuary-wide the cumulative effects methodology developed in previous years, including geographic information system (GIS) assessments of wetted area, discrete hydrodynamic modeling, and meta-analyses of effectiveness data.

The 2009 results may be summarized as follows:

- Fish and Hydrography - Large numbers of juvenile chum salmon were sampled in the tidal channels at the Kandoll Farm restoration site, implying the sampling covered the main outmigration. Juvenile Chinook salmon were present in the trap-net samples in low numbers, as in previous years. Coho salmon sampling included fry, subyearling, and yearling fishes. Marked fish from the Grays hatchery were captured at the Kandoll Farm.

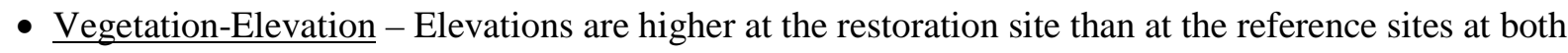
Kandoll Farm and Vera Slough. At Crims Island, the elevations are the same between restoration and reference sites. As a corollary, accretions rates are higher at restoration sites than at reference sites. All tidal wetlands examined in this study exist within a 3-m vertical range, which increases as longitudinal distance upstream from the Columbia River mouth increases. Channel density is not likely a good indicator of habitat development where preexisting channels are present, but it may be a 
useful indicator for constructed wetlands. Channel cross-sectional area typically changes most at the mouth proximal to the restoration action. Reed canary grass has become the dominant plant at the Kandoll Farm restoration site. At Crims Island, the proportion of reed canary grass is increasing (30\% in 2009). At the Vera Slough restoration site, on the other hand, bare ground has the highest percent cover. The four swamps studied have the same dominant tree species: Sitka spruce, red alder, Western red cedar, western hemlock. Line-intercept data from Kandoll Farm during 2009 show 26 herbaceous plant species that were not present in 2005-2006.

- Material Exchange - During the intensive material-exchange study at Kandoll Farm during April 2009, inorganic suspended sediments were the predominant component of total suspended sediments (TSSs) during both spring- and neap-tides series. There was a higher ( 30\%) maximum TSS concentration during spring tides than during neap tides. TSS concentration was also more variable during spring tides than neap tides. The concentration of organic suspended sediment during neapebb tides was $32 \%$ of the total TSSs compared to the neap-flood tide at $23 \%$ of total TSSs. The largest flux of neuston macrodetritus was during an ebb tide $\left(90 \mathrm{~g} / \mathrm{m}^{3}\right)$; typical concentrations were 20 to $30 \mathrm{~g} / \mathrm{m}^{3}$. Fish captured with the neuston-net included chum and stickleback during both ebb and flood tides. The highest concentration for stickleback was on a flooding tide; chum had comparable concentrations during ebb and flood. During the neap-tide series, water velocities were too low to collect neuston data.

- Action Effectiveness Meta-Analysis - The seven restoration actions studied are generally producing favorable results in terms of the photo point, water temperature, sediment accretion, and juvenile salmon presence. Meta-analysis of Site Evaluation Cards (SECs), which are succinct summaries of project actions and monitoring results, revealed that preparing the SECs requires time and dedicated and knowledgeable staff. The process is not trivial; it should be started early in the restoration planning process and updated as new information becomes available.

- Wetted Area Modeling - Habitat opportunity can be evaluated by quantifying wetted area, frequency, and duration of inundation using a GIS-based time-area inundation index. The methods developed in this study provide a means to evaluate habitat opportunities at proposed restoration sites, monitor change on existing restoration sites, understand inundation impacts under representative/altered flow regimes, determine trade-offs between water-surface elevation and habitat opportunity, and provide a standardized functional metric for site comparisons. Restored diked sites tend to be subsided and therefore have a greater frequency of inundation than the corresponding reference sites.

- Vegetation-Elevation Estuary-Wide - There is higher plant species richness in tidal freshwater areas in the mid-LCRE (river kilometer [rkm] 60 to 100) than elsewhere up or downstream.

- Historical Breaches and Created Sites - Juvenile Chinook salmon were found at all historical breaches and created sites and, overall, were second in abundance to stickleback. Size frequency distributions of juvenile salmon were similar between sites inside and outside the breach. Based on size data, all Chinook salmon sampled were subyearling fishes. Both wild and hatchery-reared salmon were using the historical breaches and created sites.

When the Cumulative Effects Study concludes in the 2010-2011 project year, we will provide three main deliverables to the USACE: a peer-reviewed, scientific method to evaluate the cumulative effects of multiple habitat restoration projects in the LCRE; an adaptive management framework and specific recommendations for infrastructure to periodically implement a comprehensive LCRE cumulative effects evaluation; and an initial cumulative effects evaluation for the LCRE based on available data and 
information. Data sources for the cumulative effects evaluation will include monitoring and GIS analysis performed by state and federal agencies and non-governmental organizations. Conversely, regional entities will be able to use GIS layers developed or improved by the Cumulative Effects Study and the levels-of-evidence approach to synthesize and evaluate their restoration effectiveness monitoring data. In total, these efforts will advance the mission of ecosystem restoration in the LCRE. 



\section{Preface}

This research was performed under the auspices of the U.S. Army Corps of Engineers Anadromous Fish Evaluation Program (study code EST-P-02-04). The study was funded by the U.S. Army Corps of Engineers Portland District (USACE) (Ref. No. AGRW66QKZ80031101) under agreements with the U.S. Department of Energy and the U.S. Department of Commerce for work by Pacific Northwest National Laboratory (PNNL) and the National Marine Fisheries Service (NMFS), respectively. Subcontractors to PNNL included the Columbia River Estuary Study Taskforce, the University of Washington, and Mr. Earl Dawley (National Marine Fisheries Services-retired). Mr. Blaine D. Ebberts was the USACE's technical lead for the study.

Technical reports and peer-reviewed publications, essential mechanisms for disseminating scientific findings, are products of this project. The project's publications and pending publications include the following:

- Diefenderfer HL and DR Montgomery. 2008. "Pool Spacing, Channel Morphology, and the Restoration of Tidal Forested Wetlands of the Columbia River, U.S.A.” Restoration Ecology 17:158-168.

- Diefenderfer HL, AM Coleman, AB Borde, and IA Sinks. 2008. “Hydraulic Geometry and Microtopography of Tidal Freshwater Forested Wetlands and Implications for Restoration, Columbia River, U.S.A.” International Journal of Ecohydrology and Hydrobiology 8:339-361.

- Roegner, GC, EW Dawley, M Russell, AH Whiting, and DJ Teel. 2010. “Juvenile Salmonid Use of Reconnected Tidal Freshwater Wetlands in Grays River, Lower Columbia River Basin.” Transactions of the American Fisheries Society 139:1211-1232

- Diefenderfer HL, RM Thom, GE Johnson, JR Skalski, KA Vogt, BD Ebberts, GC Roegner, and EM Dawley. In Press. "A Levels-of-Evidence Approach for Assessing Cumulative Ecosystem Response to Estuary and River Restoration Programs.” Ecological Restoration.

- Diefenderfer HL, GE Johnson, JR Skalski, SA Breithaupt, and AM Coleman. In Revision. "Diminishing Returns of Dike Breaching in the Restoration of Tidal Floodplain Habitat Area." Restoration Ecology.

Scientific conferences, symposia, and workshops are also important ways to transfer knowledge gained from this research. Project scientists presented papers concerning various aspects of the study at the following events during 2009:

- National Conference on Ecosystem Restoration, July 2009, Los Angeles, California.

- Coastal and Estuarine Research Federation Biennial Conference, November 2009, Portland, Oregon.

- Anadromous Fish Evaluation Program Annual Review, December 2009, Walla Walla, Washington.

Recommended citation for the entire report: Johnson GE and HL Diefenderfer (eds.). 2010. "Evaluating Cumulative Ecosystem Response to Restoration Projects in the Lower Columbia River and Estuary, 2009.” PNNL-19440, prepared by Pacific Northwest National Laboratory, Richland, Washington for the U.S. Army Corps of Engineers, Portland District, Portland, Oregon. 
Recommended citation for a chapter in the report: Borde, AB, HL Diefenderfer, SA Zimmerman, and RM Thom. 2010. "Wetland Vegetation Community Distribution and Inundation Patterns in the TidallyInfluenced Columbia River, USA.” Appendix B, pp. B1-B10, in: Evaluating Cumulative Ecosystem Response to Restoration Projects in the Lower Columbia River and Estuary, 2009, GE Johnson and HL Diefenderfer (eds.). PNNL-19440, prepared by Pacific Northwest National Laboratory, Richland, Washington for the U.S. Army Corps of Engineers, Portland District, Portland, Oregon. 


\section{Acknowledgments}

We appreciate the cooperation and collaboration on this study from the Bonneville Power Administration, the Columbia Land Trust, and the Lower Columbia River Estuary Partnership. We are grateful to the following people for their contributions to the 2009 study:

- Alejandro Bancke and Harry Rectenwald of Columbia River Estuary Study Taskforce

- Ian Sinks, Nadia Gardner, and Scott McEwen of the Columbia Land Trust

- Allan Whiting of PC Trask and Associates

- Jeni Smith, Kenneth Ham, Nikki Sather, Kate Hall, Rhonda Karls, Susan Ennor, and Mike Parker of Pacific Northwest National Laboratory

- Keith Marcoe of the Lower Columbia River Estuary Partnership

- Dave Nichols of the Illwaco Fuel Dock

- Mike Balch and Dan Bardsley of the Wahkiakum County Sheriff's office

- Poul Toftemark, Wahkiakum County resident. 



\section{Acronyms and Abbreviations}

7-DAM

ACFM

ArcGIS

BG

BiOp

BPA

${ }^{\circ} \mathrm{C}$

CFR

cfs

CLT

$\mathrm{cm}$

CNEI

CPUE

CREST

d

D $\infty$

D8

dbh

DW

ESA

EP

FCRPS

FGA

g

GIS

$\mathrm{g} / \mathrm{m}^{2}$

$\mathrm{g} / \mathrm{m}^{3}$

GPS

hr

H' 7-day average maximum daily temperature

Ash Creek Forest Management

ArcInfo Geographic Information System

bare ground

Biological Opinion

Bonneville Power Administration

degrees Celsius

Code of Federal Regulations

cubic feet per second

Columbia Land Trust

centimeter(s)

cumulative net ecosystem improvement

catch per unit effort

Columbia River Estuary Study Taskforce

day

deterministic infinity (method)

deterministic-8 (method)

diameter at breast height

debris wrack

Endangered Species Act

Estuary Partnership

Federal Columbia River Power System

filamentous green algae

gram(s)

geographic information system

gram(s) per square meter

gram(s) per cubic meter

global positioning system

hour(s)

Shannon-Wiener species diversity index 


\begin{tabular}{|c|c|}
\hline ind. $/ \mathrm{m}^{2} / \mathrm{s}$ & individual per square meter per second \\
\hline ind. $/ \mathrm{m}^{3}$ & individual(s) per cubic meter \\
\hline IRI & index of relative importance \\
\hline $\mathrm{km}$ & kilometer(s) \\
\hline $\mathrm{L}$ & liter(s) \\
\hline LCRE & lower Columbia River and estuary (rkm 0-235) \\
\hline LiDAR & light detection and ranging \\
\hline LWD & large woody debris \\
\hline $\mathrm{m}$ & meter(s) \\
\hline MG & mixed grass \\
\hline$m g L^{-1}$ & milligram(s) per liter \\
\hline $\mathrm{mL}$ & milliliter(s) \\
\hline $\mathrm{mm}$ & millimeter(s) \\
\hline $\mathrm{mm} / \mathrm{d}$ & millimeter(s) per day \\
\hline MS-222 & tricaine methane sulfonate \\
\hline $\mathrm{m}^{3} / \mathrm{s}$ & cubic meter(s) per second \\
\hline NA & not applicable \\
\hline NAVD88 & North American Vertical Datum of 1988 \\
\hline NCWA & North Coast Watershed Association \\
\hline ND & no data available \\
\hline NEI & net ecosystem improvement \\
\hline NEPA & National Environmental Policy Act of 1969 \\
\hline NMFS & National Marine Fisheries Service \\
\hline NOAA & National Oceanic and Atmospheric Administration \\
\hline NOAA Fisheries & NOAA National Marine Fisheries Service (formerly NMFS) \\
\hline $\mathrm{NO}_{2}$ & nitrate \\
\hline $\mathrm{NO}_{3}$ & nitrite \\
\hline OPUS & Online Positioning User Service \\
\hline PNNL & Pacific Northwest National Laboratory \\
\hline $\mathrm{PO}_{4}$ & phosphate \\
\hline ppt & parts per thousand \\
\hline rkm & river kilometer \\
\hline RMS & Root Mean Square(d) \\
\hline RTK & real-time kinematic \\
\hline
\end{tabular}


$\mathrm{S}$

SBWC

s.d.

SEC

$\mathrm{SiO}_{4}$

SS

TGO

TN

TN1, TN2

TOC

TSS

UID

USACE

yr second(s)

Scappoose Bay Watershed Council

standard deviation

Site Evaluation Card

silicate

Seal Slough

Trimble Geomatics Office

trap net

trap-net site 1 , trap-net site 2 , etc.

total organic carbon

total suspended sediment

unidentified

U.S. Army Corps of Engineers

year(s) 



\section{Contents}

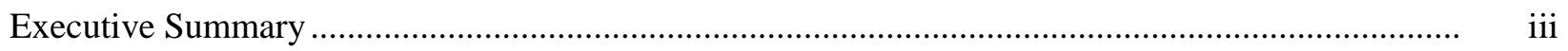

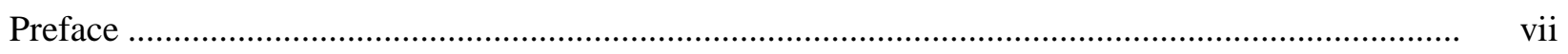

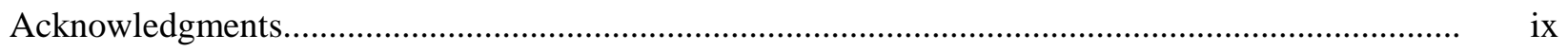

Acronyms and Abbreviations .............................................................................................. xi

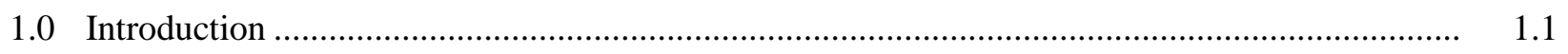

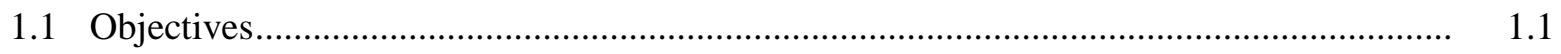

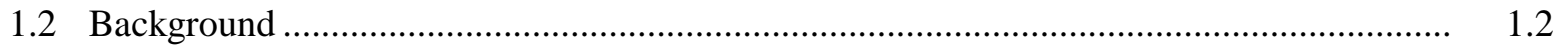

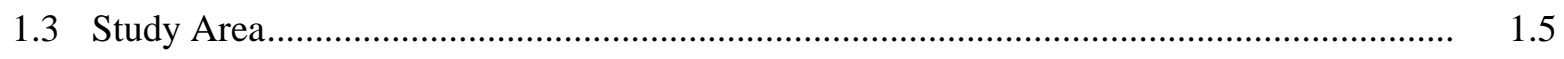

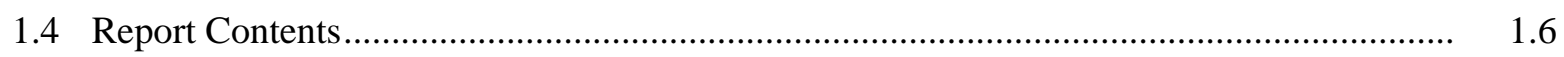

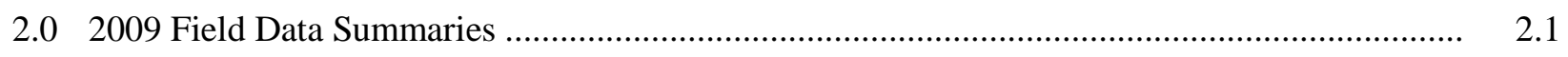

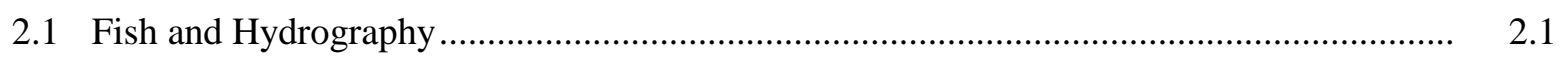

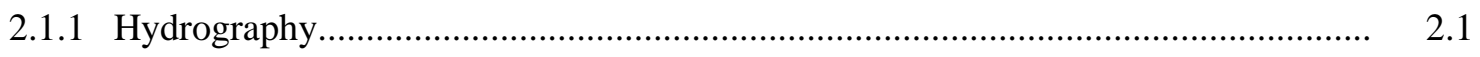

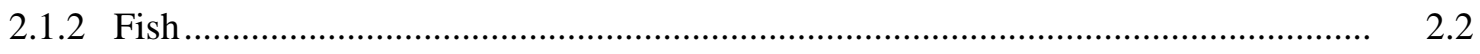

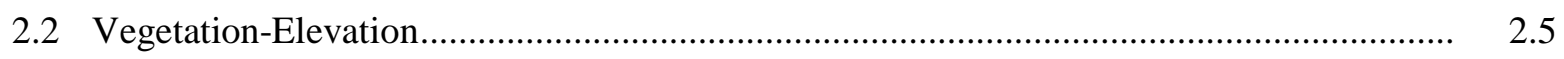

2.2.1 Plant Cover and Elevation...................................................................................... 2.6

2.2.2 Sediment Accretion ..................................................................................... 2.10

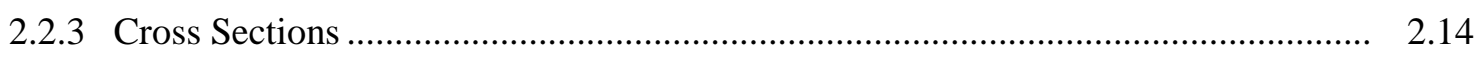

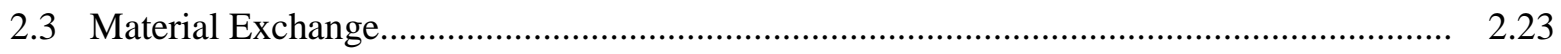

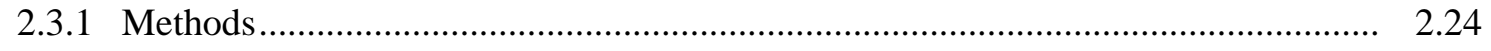

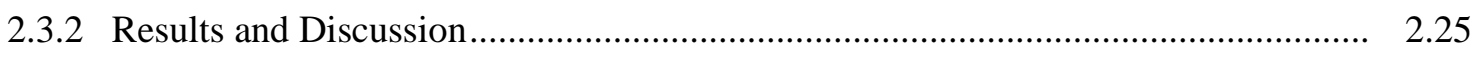

3.0 Action Effectiveness Meta-Analysis ............................................................................. 3.1

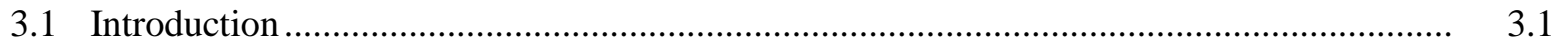

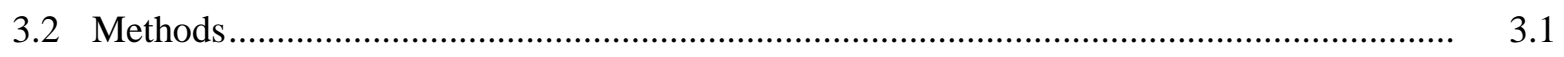

3.2.1 Project Sites.................................................................................................

3.2.2 Site Evaluation Cards …............................................................................... 3.3

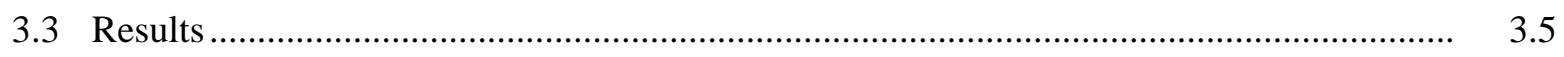

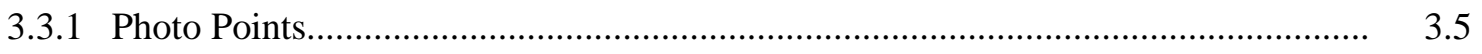

3.3.2 Water Temperature..................................................................................... 3.8

3.3.3 Sediment Accretion Rate............................................................................. 3.8

3.3.4 Juvenile Salmon Presence ..................................................................................... 3.10

3.3.5 Site Evaluation Cards .................................................................................... 3.11

3.3.6 Summary and Recommendations ................................................................. 3.11

4.0 Conclusions and Recommendations ................................................................................. 4.1

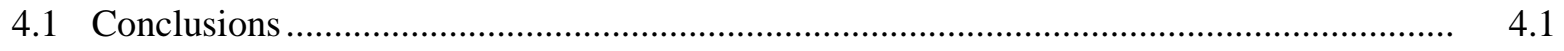

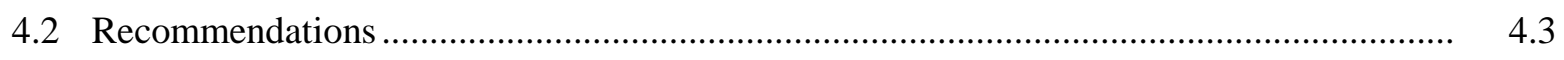

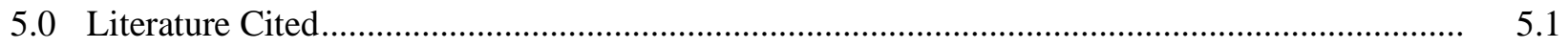


Appendix A - Spatially Based Area-Time Inundation Index Model Applied in Tidal

Wetlands of the Lower Columbia River and Estuary

Appendix B - Wetland Vegetation Community Distribution and Inundation Patterns

in the Tidally Influenced Columbia River, USA.

Appendix C - Ecological Trajectories and Salmon Habitat Functions of Historical Dike

Breaches and Created Islands in the Columbia River Floodplain, USA

C.1

\section{Figures}

1.1 The Lower Columbia River and Estuary - Bonneville Dam to the Pacific Ocean.....

1.2. Assessment of the Cumulative Effects of Ecosystem Restoration by a Levels-ofEvidence Approach.

1.3 Field Sites for the Cumulative Effects Study

2.1 Hydrography at Kandoll Farm During 2009 Fish Sampling.

2.2 Time Series of Salmon CPUE at Paired Kandoll Farm Trap-Net Sites 2007-2009.

2.3 Combined Size Frequency Histograms of Salmonids at Kandoll Farm Trap-Net Sites in 2009 Showing Life-History Stages .....

2.4 Diet of Coho Salmon at Kandoll Farm Restoration Sites in 2009.

2.5 Salmon Relative Annual Abundance Versus 7-DAM Temperature, 2009

2.6 Herbaceous Vegetation Cover and Species Elevation Ranges at Vera Slough Restoration and Reference Sites During 2009

2.7 Herbaceous Vegetation Cover and Species Elevation Ranges at Kandoll Farm Restoration and Reference Sites During 2009

2.8 Herbaceous Vegetation Cover and Species Elevation Ranges at Crims Island Restoration and Reference Sites During 2009

2.9 Comparison of Sediment Accretion Rates at Reference Swamps and Restoration Sites.

2.10 Channel Cross Sections Before and After Tide-Gate Replacement at the Vera Slough Restoration Site.....

2.11 Channel Cross Sections at the Vera Slough Reference Site

2.12 Cross Sections at a Reference Channel Before and After Nearby Restoration and Enhancement Actions at Kandoll Farm

2.13 Three Dike Breaches on the Grays River at Kandoll Farm, 2005-2009.

2.14 Channel Cross Sections on One Channel on the Grays River at Kandoll Farm, Before and After the Dike at Its Mouth Was Breached

2.15 Cross Sections at Five Locations on Upper Seal Slough in Kandoll Farm

2.16 Channel Cross Sections at Crims Island Restoration Site for 1, 2 and 4 Years after Restoration

2.17 Total, Inorganic, and Organic Suspended Sediment Concentration: Kandoll Farm through Time during a Spring Tide.

2.18 Total, Inorganic, and Organic Suspended Sediment Concentration: Kandoll Farm through Time during a Neap Tide. 
2.19 Average Concentration of Total, Inorganic, and Organic Suspended Sediments During Various Tidal Stages of a Spring-Tide Series at Kandoll Farm.

2.20 Average Concentration of Total, Inorganic, and Organic Suspended Sediments During Various Tidal Stages of a Neap-Tide Series at Kandoll Farm

2.21 Instantaneous Concentration of Stickleback and Chum Salmon During the Spring Sampling Period..... 2.28

2.22 Instantaneous Concentration of Macrodetritus During the Spring-Tide Sampling Period

2.23 Abundance of Chum Salmon and Stickleback at Trap-Net Sites During Spring and Neap Sampling Periods.

2.24 Time Series of Mean Daily Temperature and Light Intensity.....

3.1 Pre- and Post-Restoration Photo Points for the Seven Restoration Projects Included in the Meta-Analysis

3.2 Temperature Data Pre- and Post-Restoration......

\section{Tables}

1.1 Summary of Accomplishments in the Cumulative Effects Study

2.1 Summary of 2009 Shrub Stem Frequency, Density, and Elevation at the Kandoll Reference Swamp.

2.2 Summary of 2009 Tree Cover at the Kandoll Reference Swamp

2.3 Plant Species on a Line-Intercept Transect in Five Fields at Kandoll Farm in 2005, 2006, and 2009.

2.4 Summary of Sediment Accretion Rates at Paired Restoration and Reference Sites

2.5 List of Fish Species Observed During the Intensive Material-Exchange Study

2.6 Abundance of Fish Captured at Trap-Net Sites During the Spring and Neap Periods of the Intensive Material-Exchange Study .....

3.1 Descriptive Data about Restoration Sites

3.2 Data Availability at the Seven Sites Selected for Meta-Analysis

3.3 Two-Part Template for a Site Evaluation Card....

3.4 Sediment Accretion Rates at Paired Restoration and Reference Sites

3.5 Pre- and Post-Restoration Juvenile Salmon Presence 



\subsection{Introduction}

This is the sixth annual report of a seven-year project (2004-2010) to evaluate the cumulative effects of habitat restoration actions in the 235-km-long lower Columbia River and estuary (LCRE; ${ }^{1}$ Figure 1.1). The project, called the Cumulative Effects Study, is being conducted for the U.S. Army Corps of Engineers Portland District (USACE) by the Marine Sciences Laboratory of the Pacific Northwest National Laboratory, the Pt. Adams Biological Field Station of the National Marine Fisheries Service (NMFS), the Columbia River Estuary Study Taskforce (CREST), and the University of Washington (UW).

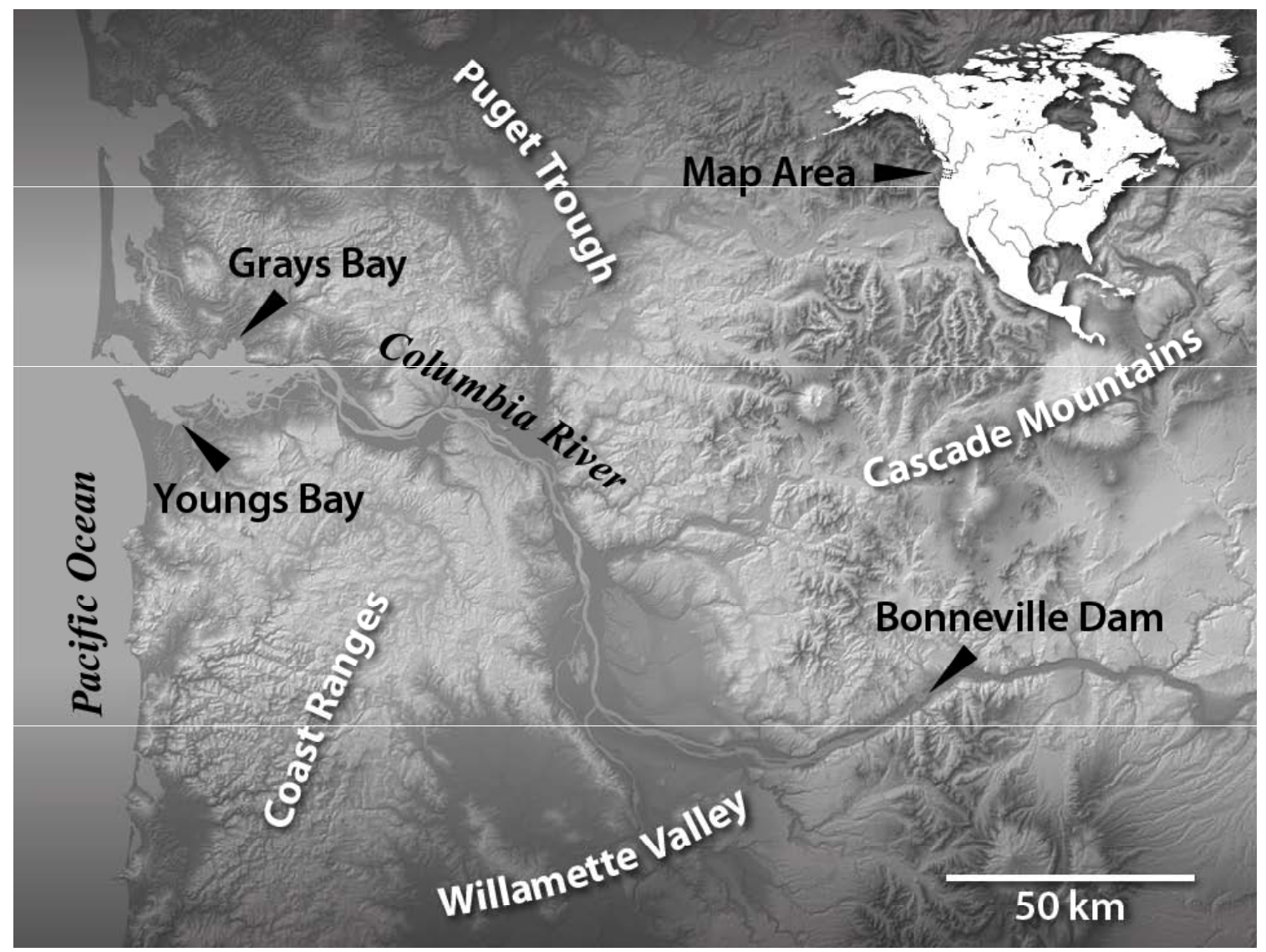

Figure 1.1. The Lower Columbia River and Estuary - Bonneville Dam to the Pacific Ocean

\subsection{Objectives}

The overall objectives of this multi-year (2004-2011) study are as follows:

- Develop standard monitoring protocols and methods to prioritize monitoring activities that can be applied to LCRE habitat restoration activities for listed salmon.

\footnotetext{
${ }^{1}$ By definition, the LCRE includes the river and its floodplain from Bonneville Dam to the mouth of the river.
} 
- Develop the empirical basis for a cumulative assessment methodology, together with a set of metrics and a conceptual model depicting the cumulative effects of LCRE restoration projects on key major ecosystem functions supporting listed salmon.

- Design and implement field evaluations of the cumulative effects methodologies by applying standard methods, a geographic information system (GIS) database ${ }^{1}$ of habitat types and land ownership (private, federal, state, local), hydrodynamic model, and meta-analyses to assess through-ecosystem response of the cumulative effects of multiple habitat restoration projects.

- Develop an adaptive management framework that coordinates and compares the diverse restoration efforts in the LCRE, including data management and dissemination, to support decisions by the USACE and others regarding LCRE habitat restoration activities.

The 2009 Cumulative Effects Study involved a large-scale field effort 4 years after the baseline work at the Crims Island, Kandoll Farm, and Vera Slough (also referred to as Crims, Kandoll, and Vera) restoration sites. During 2009, the specific objectives were to accomplish the following:

1. Support the cumulative effects assessment at pilot and estuary-wide scales through field work to document selected higher-order metrics, develop a time series of monitored indicators, and expand the spatial and temporal diversity of sites for cumulative effects analysis, as follows:

a. At Crims, Kandoll, and Vera restoration and reference sites, sample all core metrics.

b. At selected historical breach and created sites, sample hydrology, channel morphology, vegetation, and fish abundance.

c. Perform an intensive material-exchange study at Kandoll over 48-hour periods during a spring and a neap-tide series.

2. Test estuary-wide the cumulative effects methodology developed in previous years, including GIS assessments of wetted area, discrete hydrodynamic modeling, and meta-analyses of effectiveness data.

\subsection{Background}

The USACE is working with federal, state, and local agencies and non-governmental organizations to restore estuarine habitats in the LCRE. The restoration effort, herein called the Federal Columbia River Estuary Restoration Program, is driven by various Water Resources Development Acts and the Biological Opinion (BiOp) on operation of the Federal Columbia River Power System (FCRPS) (NOAA 2008). Overall, the goal of the program is to understand, conserve, and restore the estuary ecosystem to improve the performance of listed salmonid populations (Johnson et al. 2008).

Many LCRE restoration activities involve the hydrologic reconnection of portions of the estuarine system currently isolated by dikes, tide gates, culverts, and other barriers. The intent is to improve the functionality of the LCRE ecosystem through habitat restoration efforts (Johnson et al. 2003). This will aid in rebuilding salmonid stocks of the Columbia River basin that are currently listed under the Endangered Species Act (ESA) (NOAA 2008). In addition, cumulative effects methodology will be

\footnotetext{
${ }^{1}$ The GIS database is a collaborative, coordinated effort among multiple parties, including the Columbia River Estuary Study Taskforce, the Lower Columbia River Estuary Partnership, the Pacific Northwest National Laboratory, the University of Washington, and the U.S. Geological Survey.
} 
useful in guiding the design and monitoring of individual LCRE habitat restoration projects, fulfilling actions authorized in Water Resources Development Acts, implementing offsite mitigation measures called for in the FCRPS BiOp, and evaluating the success of the Estuary Restoration Program. Essentially, managers want to know the following:

- Are protection and restoration resulting in continued loss, no net loss, or net ecosystem improvement in the context of continuing land conversion?

- What suite of projects results in an increase in habitat opportunity and capacity for juvenile salmon?

- What suite of projects produces increased habitat connectivity, maximum flood attenuation, sediment trapping, nutrient processing, return of marsh macrodetritus, and other ecosystem functions?

- What are the survival benefits to juvenile salmonids from LCRE habitat restoration actions?

Understanding the cumulative effects of ecological restoration projects in the LCRE is a formidable task because of the size and complexity of the LCRE landscape (Small 1990). Despite the challenges presented by this system, developing and implementing appropriate indicators and methods to evaluate cumulative effects is possible and will enable estuary managers to assess and improve the overall effectiveness of investments in estuary restoration projects. This study is intended to both develop methods for quantifying the effects of restoration projects and lay a foundation for future effectiveness, ${ }^{1}$ evaluation, and validation ${ }^{2}$ of cumulative restoration activities in the LCRE.

Since 2004, the Cumulative Effects Study has helped further restoration science in the LCRE (Table 1.1). A significant advance was the development of the levels-of-evidence approach for assessing the cumulative effects of restoration projects on the LCRE ecosystem (Figure 1.2; Diefenderfer et al. In Revision). Johnson and Diefenderfer (2009) summarized the results of annual studies up to and including 2008.

Table 1.1. Summary of Accomplishments in the Cumulative Effects Study

\begin{tabular}{|c|c|c|}
\hline $\begin{array}{l}\text { Study- } \\
\text { Year }\end{array}$ & Accomplishments & Citation \\
\hline \multirow[t]{4}{*}{2004} & $\begin{array}{l}\text { Performed a comprehensive literature review that found no published formal methods } \\
\text { to quantify the cumulative effects of multiple restoration projects across one estuary. }\end{array}$ & $\begin{array}{l}\text { Diefenderfer } \\
\text { et al. (2005) }\end{array}$ \\
\hline & $\begin{array}{l}\text { Initiated development of protocols for monitoring restoration activities with a meeting } \\
\text { open to all estuary restoration project managers, which is an important step toward } \\
\text { achieving a cumulative assessment of restoration effects. }\end{array}$ & \\
\hline & $\begin{array}{l}\text { Adopted the following definition of cumulative effects: “The impact on the } \\
\text { environment which results from the incremental impact of the action when added to } \\
\text { other past, present, and reasonably foreseeable future actions regardless of what } \\
\text { agency (Federal or non-Federal) or person undertakes such other actions" (Title } 40 \\
\text { of the Code of Federal Regulations [CFR] § 1508.7). }\end{array}$ & \\
\hline & $\begin{array}{l}\text { Proposed a levels-of-evidence approach (Downes et al. 2002) to evaluate cumulative } \\
\text { effects. }\end{array}$ & \\
\hline
\end{tabular}

\footnotetext{
${ }^{1}$ Effectiveness monitoring involves activities designed and undertaken to assess how well a particular restoration project performs relative to reference site(s).

${ }^{2}$ Validation monitoring involves activities directed at testing cause-and-effect relationships between management activities and monitoring indicators (Busch and Trexler 2003).
} 
Table 1.1. (contd)

\begin{tabular}{|c|c|c|}
\hline $\begin{array}{l}\text { Study- } \\
\text { Year }\end{array}$ & Accomplishments & Citation \\
\hline \multirow[t]{4}{*}{2005} & $\begin{array}{l}\text { Developed hypotheses regarding the effects of hydrological-reconnection } \\
\text { restoration methods; refined the selection of measurable metrics. }\end{array}$ & \multirow[t]{4}{*}{$\begin{array}{l}\text { Diefenderfer et al. } \\
\text { (2006) }\end{array}$} \\
\hline & $\begin{array}{l}\text { Tested restoration effectiveness monitoring protocols; continued to develop a } \\
\text { sampling design supporting an estuary-wide cumulative effects analysis. }\end{array}$ & \\
\hline & $\begin{array}{l}\text { Initiated development of an adaptive management framework for the LCRE } \\
\text { Restoration Program. }\end{array}$ & \\
\hline & $\begin{array}{l}\text { Applied effectiveness monitoring methodology before construction restoration } \\
\text { actions at two restoration sites and two reference sites in the Columbia River } \\
\text { estuary_-Vera Slough and Kandoll Farm—as paired site studies of marsh and } \\
\text { swamp habitats, respectively. }\end{array}$ & \\
\hline \multirow[t]{2}{*}{2006} & $\begin{array}{l}\text { Conducted post-restoration research at the selected study sites to support the } \\
\text { ongoing development of a technical approach for assessing the cumulative effects of } \\
\text { multiple aquatic habitat restoration projects in the LCRE. }\end{array}$ & \multirow[t]{2}{*}{$\begin{array}{l}\text { Johnson (ed.) } \\
\text { (2007) }\end{array}$} \\
\hline & $\begin{array}{l}\text { Collected data for cumulative effects analysis from three sources using the levels- } \\
\text { of-evidence approach (2005 and } 2006 \text { combined): in-depth paired site studies } \\
\text { (marsh and swamp), selected core indicators at all monitored restoration project and } \\
\text { reference sites, and cumulative effects indicators. }\end{array}$ & \\
\hline \multirow[t]{4}{*}{2007} & Released draft monitoring protocols and conducted a regional workshop about them. & \multirow{4}{*}{$\begin{array}{l}\text { Johnson and } \\
\text { Diefenderfer } \\
\text { (eds.) (2008) }\end{array}$} \\
\hline & $\begin{array}{l}\text { Developed a detailed adaptive management framework for the LCRE Restoration } \\
\text { Program. }\end{array}$ & \\
\hline & $\begin{array}{l}\text { Continued development of the scientific approach for cumulative effects } \\
\text { assessment. }\end{array}$ & \\
\hline & $\begin{array}{l}\text { Provided monitoring data summaries for Julia Butler Hanson, Crims Island, } \\
\text { hydrology, material flux, and the natural breach assessment. }\end{array}$ & \\
\hline \multirow[t]{3}{*}{2008} & $\begin{array}{l}\text { Applied results from 2005-2008 field research and modeling to develop predictive } \\
\text { structure/function relationships as indicators of fundamental processes. }\end{array}$ & \multirow{3}{*}{$\begin{array}{l}\text { Johnson and } \\
\text { Diefenderfer } \\
\text { (eds.) (2009) }\end{array}$} \\
\hline & $\begin{array}{l}\text { Conducted hydrodynamic modeling to test for synergies in wetted area resulting } \\
\text { from various dike breach scenarios. }\end{array}$ & \\
\hline & $\begin{array}{l}\text { Acquired intensive and extensive effectiveness monitoring data from restoration and } \\
\text { reference sites and performed a preliminary meta-analysis of effectiveness } \\
\text { monitoring data, in cooperation with the Lower Columbia River Estuary Partnership } \\
\text { and CREST. }\end{array}$ & \\
\hline
\end{tabular}




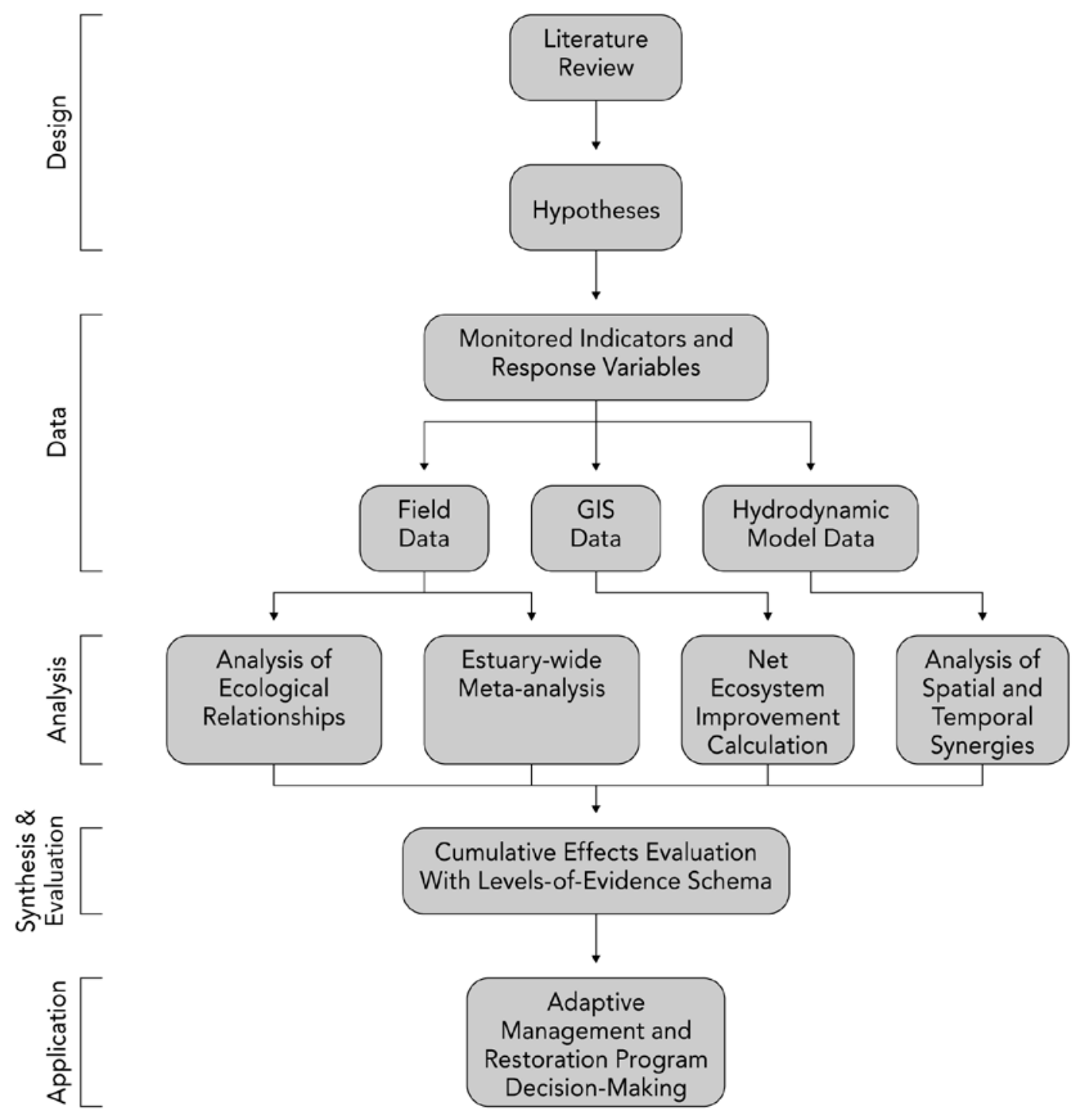

Figure 1.2. Assessment of the Cumulative Effects of Ecosystem Restoration by a Levels-of-Evidence Approach (GIS stands for geographic information system)

\subsection{Study Area}

For the general purposes of the Cumulative Effects Study, Diefenderfer et al. (2005) describe the LCRE study area. A number of publications also provide useful descriptive information about the study area, including Salmon at River's End (Bottom et al. 2005), Role of the Estuary in the Recovery of Columbia River Basin Salmon and Steelhead (Fresh et al. 2004), and Ecosystem-Based Approach to Habitat Restoration Projects (Johnson et al. 2003).

During 2005-2009, field studies for the Cumulative Effects Study occurred at selected sites in the LCRE: Vera Slough, Kandoll Farm, Julia Butler Hanson Wildlife Refuge, and Crims Island (Figure 1.3). 
Two plant communities representing the salmon habitat types that were historically most common at each of these sites and most likely to be restored today were chosen for field studies: tidal freshwater swamps in the tidal freshwater region and tidal brackish marsh in the brackish water region. Within each of the habitat types, at least one natural reference site and at least one restoration site were studied. Site selection was based in part on the timing of planned restoration, because the monitoring protocols recommend collecting data before and after implementation of restoration actions.

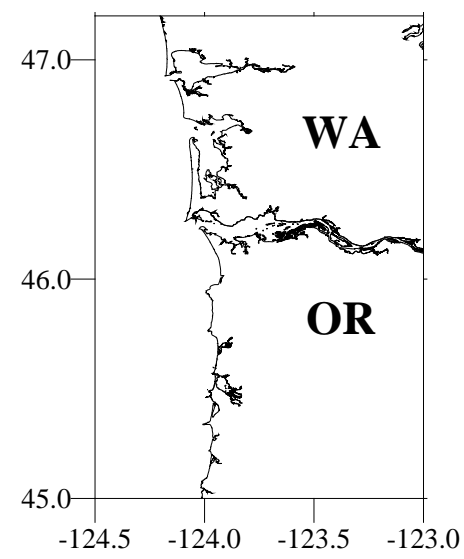

\section{Tide gate removal}

Kandoll Farms Grays River

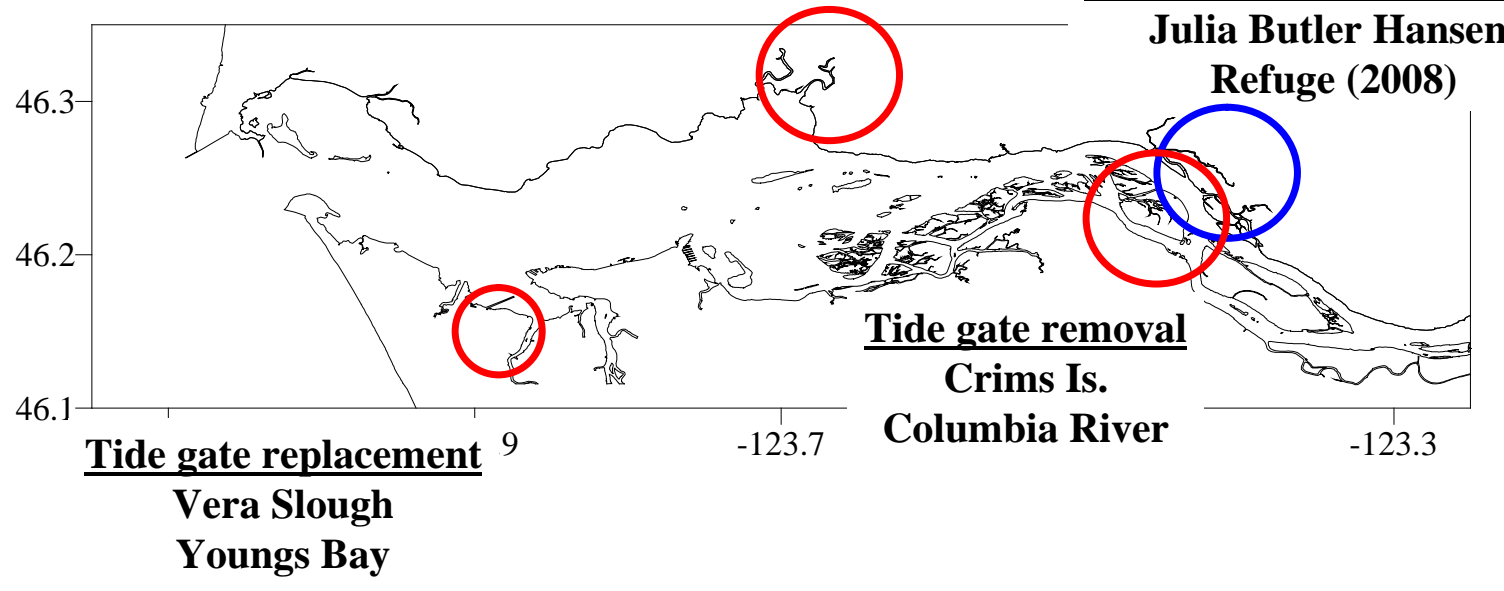

Figure 1.3. Field Sites for the Cumulative Effects Study

\subsection{Report Contents}

This report contains five main sections and three appendices. Section 2.0 provides field data summaries for fish, vegetation-elevation, and flux. Section 3.0 builds on the meta-analysis begun in 2008 of effectiveness monitoring data. Section 4.0 contains conclusions and recommendations, including lessons learned to date from restoration monitoring data. Section 5.0 lists the literature cited. Appendices contain draft manuscripts on wetted area modeling (Appendix A), vegetation-elevation (Appendix B), and natural breach and habitat creation sites (Appendix $\mathrm{C}$ ). The discrete hydrodynamic modeling we performed to supplement results reported for the 2008 study is not reported herein because it will be included in the paper titled "Diminishing Returns of Dike Breaching in the Restoration of Tidal Floodplain Habitat Area.” 


\subsection{Field Data Summaries}

This section contains data summaries for three discrete field efforts during 2009: fish, vegetationelevation, and intensive flux. By design, the data summaries are light on methods and discussion and heavy on results. Write-ups for these and other data will be thoroughly developed in the 2010 synthesis report.

\subsection{Fish and Hydrography}

\section{Prepared by Curtis Roegner, April Cameron, April Silva, Micah Russell, and Earl Dawley}

The goal of the 2007-2009 fish sampling was to explore the spatial-temporal distribution of salmonid habitat use in the Kandoll Farm restoration site. During 2009, the final field season, we continued the biweekly trap-net sampling for fish species, abundance, and size at two adjacent intertidal channels. The study was initiated in May 2007, and sampling during 2008 and 2009 extended from early February through the end of June. We have collected 3 years of data from trap-net site 1 (TN1) and 2.5 years of data from trap-net site 2 (TN2). In addition, a third trap-net site (TN3) was operated during the Intensive Material Exchange Study (see Section 2.3). Data on salmon habitat use among Kandoll Farm and Johnson Farm restoration sites and Grays River reference sites collected during 2005-2007 are under review (Roegner et al. 2010). For this annual report, we present our initial findings for the 2009 data, with some comparisons to previous years.

\subsubsection{Hydrography}

\subsubsection{Methods}

We continued to monitor system hydrography with a network of pressure/temperature sensors (HOBO ${ }^{\circledR}$ model U20-001-04, Onset Corp) and temperature-light sensors (HOBO model U20-001-04, Onset Corp) established at stations within and surrounding the restoration sites. At each station, instruments were secured to vertical poles or on bottom weights. The temperature-light sensors monitored temperature at the Kandoll trap-net sites. The time series is used to evaluate periods of suitable water-quality conditions for rearing salmonids. To achieve this, we calculated the 7-day average maximum daily temperature (7-DAM or 7-DAM temperature) and refer to a critical threshold of $16^{\circ} \mathrm{C}$ as the upper criterion for optimum thermal conditions (EPA 2003; Richter and Kolmes 2005). Here we compare the temperature time series from the various Kandoll trap-net sites.

\subsubsection{Results}

The 7-DAM temperature time series in the three trap-net tidal channels were remarkably similar among sites from February through May (Figure 2.1a). Temperature was lower in TN1 during late June and July, likely as a result of sensor burial. All 7-DAM temperature time series exceeded the $16^{\circ} \mathrm{C}$ criterion during late April through August, and exceeded $19^{\circ} \mathrm{C}$ for most of June and July. Temperatures above $19^{\circ} \mathrm{C}$ can be stressful for salmonids. Spectral analysis of light intensity showed typical periodicities based on day length (Figure 2.1b). Spectral analysis of the temperature time series shows strong periodicity at semidiurnal tidal time periods (Figure 2.1c), indicating tidal flux is responsible for much of the temperature variation. 


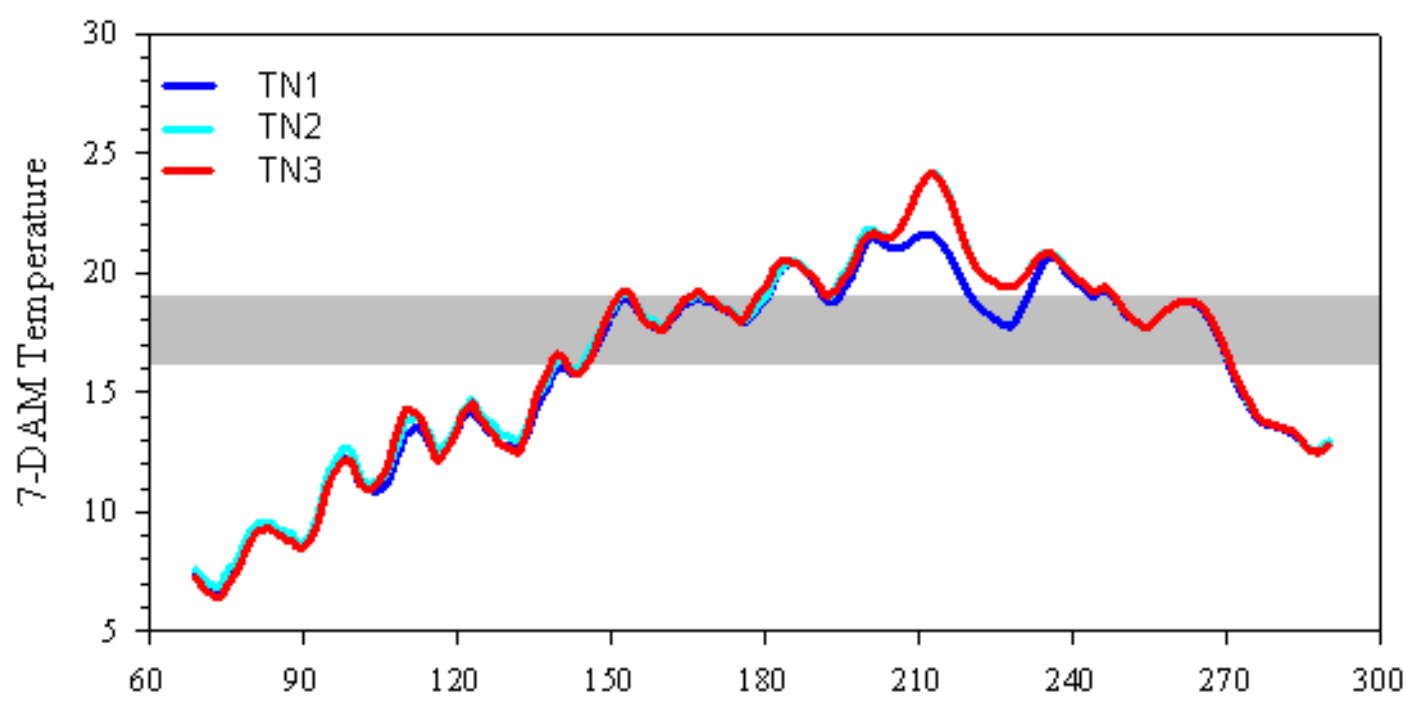

Day in 2009
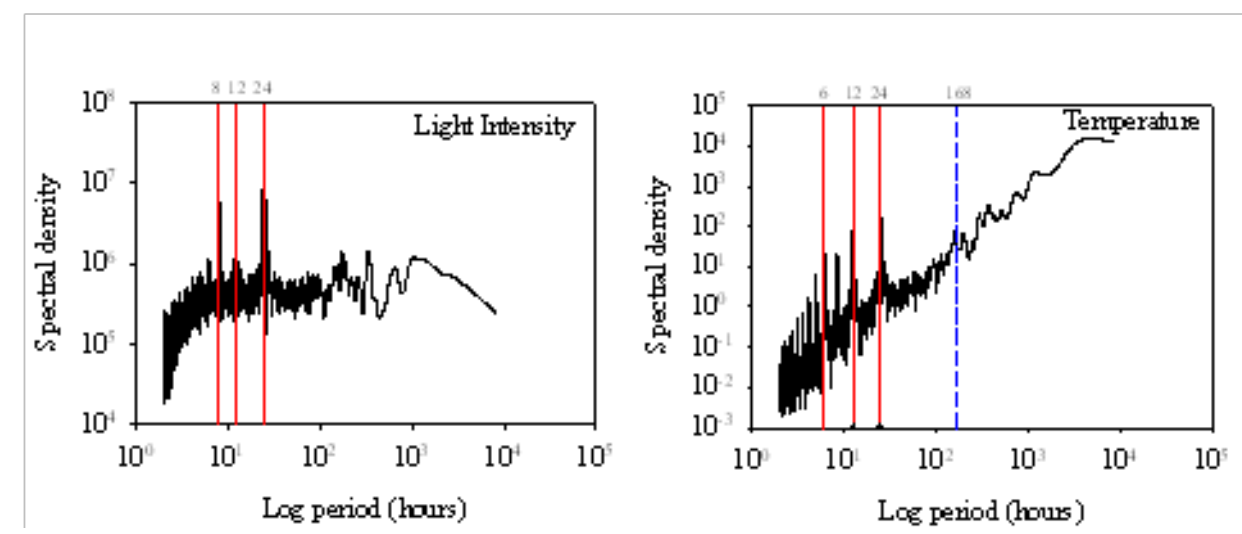

Figure 2.1. Hydrography at Kandoll Farm During 2009 Fish Sampling. A) 7-DAM Temperature at Kandoll Farm trap-net sites in 2009 (top). B) Spectral density of light intensity (bottom left). C) Spectral density of temperature (bottom right).

\subsubsection{Fish}

\subsubsection{Methods}

The 2009 fish data continue the spatio-temporal assessment of salmon habitat use at Kandoll Farm. We deployed paired trap (fyke) nets in developing intertidal channels. TN1 was located at our long-term sampling site and extends that time series to 3 years. TN2 was located approximately $100 \mathrm{~m}$ from TN1 in an adjacent tidal channel. The trap nets were composed of two 15-x-2.4-m net leads connected to a $0.75 \mathrm{~m}^{2}$ throat and 1.8-m-long cod end. The nets were set at high water and fished for 4 to 5 hours during the outgoing (ebb) tide to catch fish moving toward the river as the water within the channel drained.

All fish were identified to species, enumerated, and measured to the nearest millimeter. Salmonids were anesthetized with a $50-\mathrm{mg} \mathrm{L}^{-1}$ solution of tricaine methane sulfonate (MS-222) before measurement. We closely examined salmon for any external marks indicating hatchery production. We used gastric lavage to sample the stomach contents of suitably sized juvenile coho and Chinook salmon (chum being 
too small) to determine prey use. This non-lethal method uses filtered water flushed into the stomach to evacuate the contents into a sample jar fixed with $10 \%$ formalin.

\subsubsection{Results}

We plotted salmon catch per unit effort (CPUE) by day of year to generalize temporal trends and to compare the CPUE with the 2007 and 2008 abundances (Figure 2.2). The timing of salmon use varied among sites and years. During 2009, Chinook salmon continued to be present at low abundances from February through June. In contrast, very large catches of chum salmon were made April 2009 in conjunction with the spring-tide sampling for the Intensive Material Exchange Study (Section 2.3). In general, patterns of abundance among years for chum salmon were similar, with highest wetland use in March-April and a sharp decline in early May. Coho salmon were moderately abundant and had a more variable pattern extending from March through June with peak abundance usually in May or June.

Comparisons of CPUE among sites will require standardization by area.

Chinook
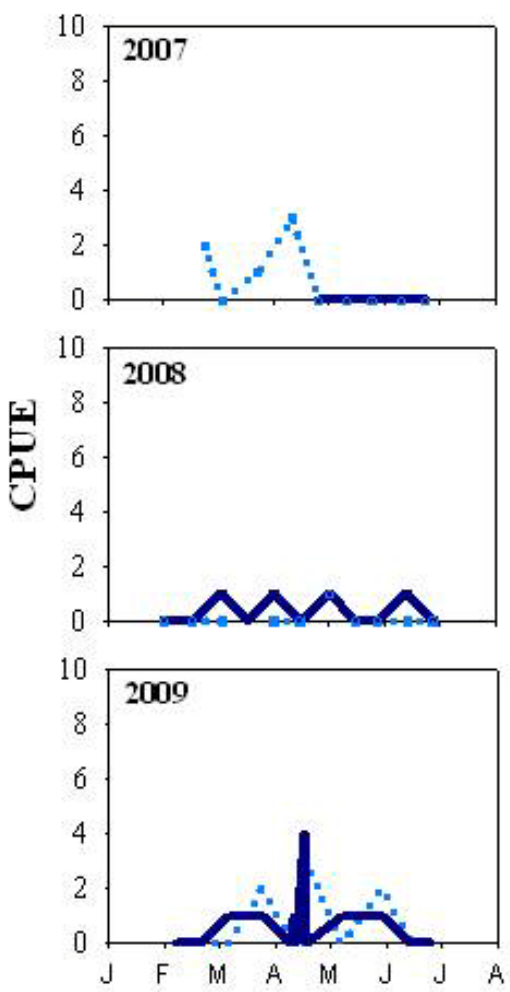

Chum
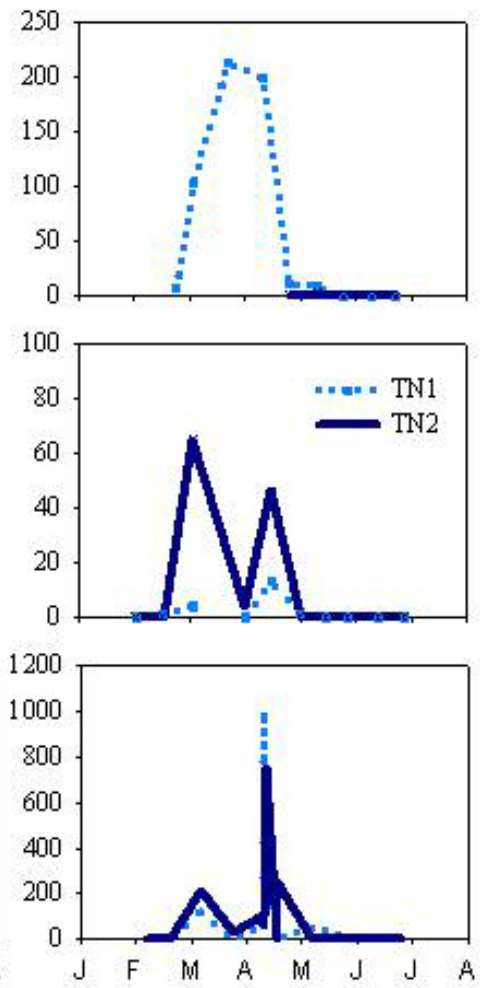

Coho
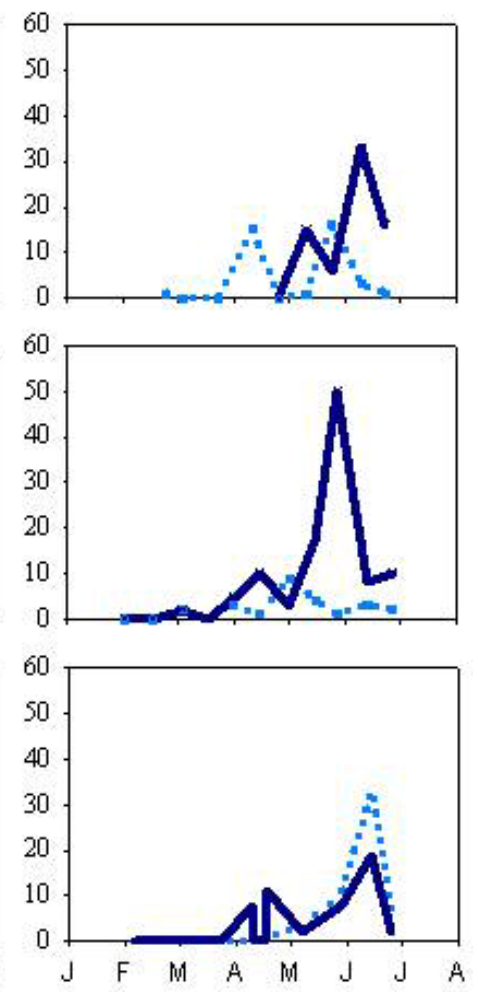

Figure 2.2. Time Series of Salmon CPUE at Paired Kandoll Farm Trap-Net Sites 2007-2009. During 2007, the second trap-net time series was initiated in May.

Size-frequency histograms (Figure 2.3a) and size-at-date plots (Figure 2.3b, c) reveal the life-history stages present in the system. The Chinook salmon population was composed mostly of fry with a few fingerling and yearling fish. The size-at-date plot for 2009 was similar to data collected for the years 2005-2007 (Roegner et al. 2010), and the adipose-fin-clipped fish were likely migrants from outside the Grays River system (Figure 2.3b, c). Non-clipped and especially fry-sized Chinook salmon were likely of natural origin. The chum salmon were all fry and exhibited no increase in size with time. A batch in early May was of hatchery-release size (Figure 2.3c), but to our knowledge chum hatchery production in 
the Grays River has ceased. These late fish may have had an extended growing period in the wetlands. The coho salmon population using the restored wetlands was composed of fry, fingerling, and yearling fish. The subyearling size-at-date trajectory was very similar to that of the composite from 2005-2007, with an inferred growth rate of $0.38 \mathrm{~mm} / \mathrm{d}$ (Figure 2.3b, c). In contrast to previous years, we detected no wild yearling fish during 2009; the yearlings were almost all adipose-fin-clipped and all were captured just after the date of the hatchery release.

a)
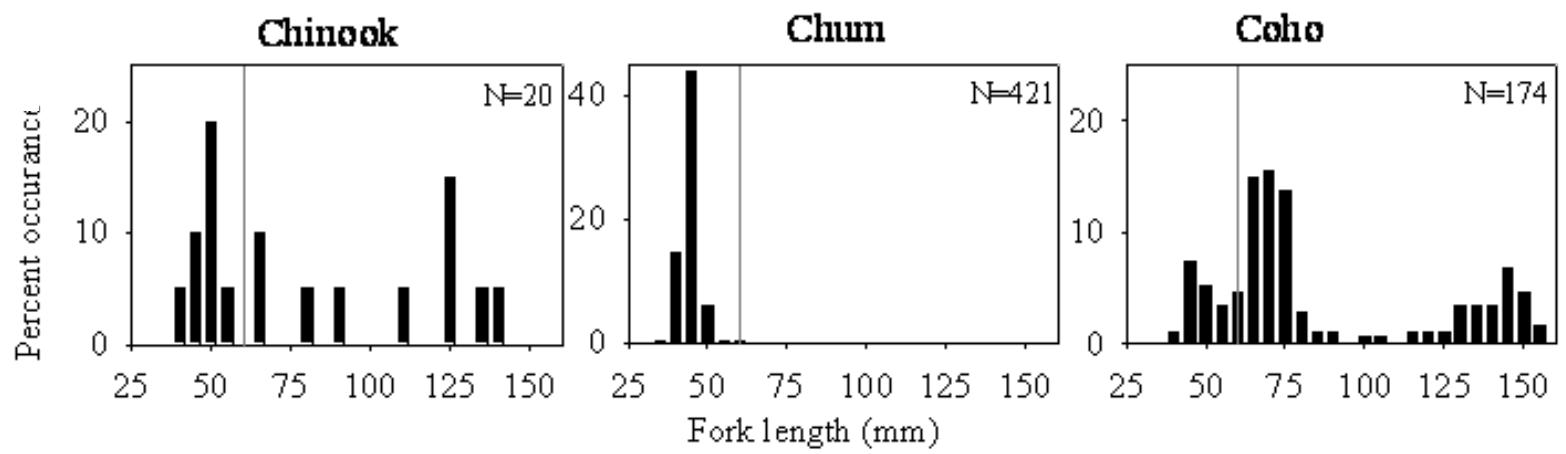

b)
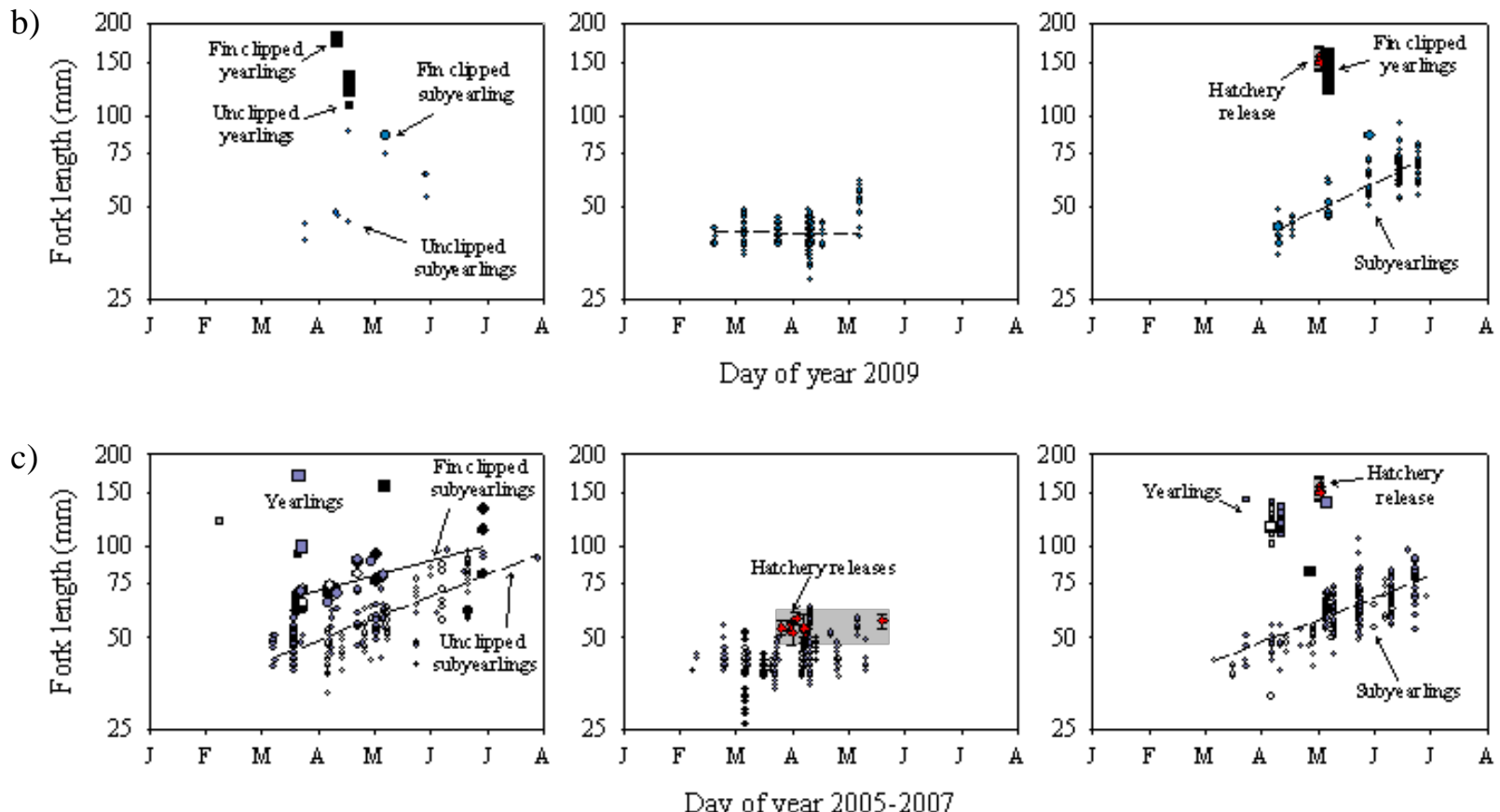

Figure 2.3. A) Combined Size Frequency Histograms of Salmonids at Kandoll Farm Trap-Net Sites in 2009 Showing Life-History Stages. Vertical line at $60 \mathrm{~mm}$ delineates fry from fingerlingsized individuals. Numbers indicate the quantity of fish comprising the frequency distribution. B) and C) Salmon size (log10 scale) by time during 2009 (B) and as a composite from 2005-2007 (C). Life-history is denoted by symbol type (square = yearlings; circle $=$ subyearlings). Hatchery status is denoted by symbol size (large symbol $=$ adiposefin clip; small symbol = unclipped fish). In B, all samples were collected from trap-net sites. In $\mathrm{C}$, sample location is denoted by color (white = Grays River seine stations $1-3$; blue = Grays River mouth; black = Kandoll and Johnson trap-net sites). Red symbols show the mean size \pm s.d. of hatchery releases. 
Coho were the only salmonid large and abundant enough for diet analysis (Figure 2.4). The coho were mainly feeding on insects (high abundance) and annelids (high weight).
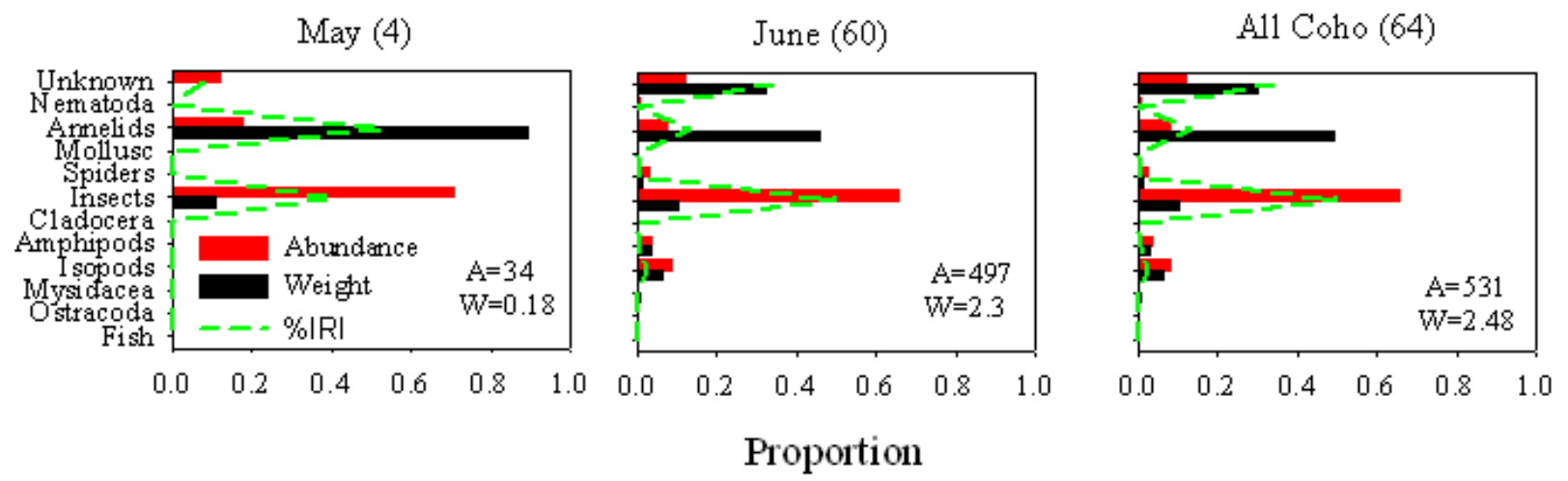

Figure 2.4. Diet of Coho Salmon (number in parenthesis) at Kandoll Farm Restoration Sites in 2009. $\mathrm{A}$ = number of prey items; $\mathrm{W}$ = wet weight of prey items (g); IRI = index of relative importance.

We plotted salmon relative annual CPUE by 7-DAM temperature for each trap-net site to investigate salmon distribution based on thermal regime (Figure 2.5). Note that TN3 was only sampled for five tides. Chinook salmon had a relatively wide thermal distribution around 9 to $17^{\circ} \mathrm{C}$, but recall that the overall abundance of Chinook salmon was low. Chum salmon had a sharp peak at around $12^{\circ} \mathrm{C}$, whereas in the past peak abundances were in a wider range of about 9 to $12^{\circ} \mathrm{C}$. Coho salmon were also widely distributed with 7-DAM temperature, and abundances were higher at the upper range of about $18^{\circ} \mathrm{C}$.
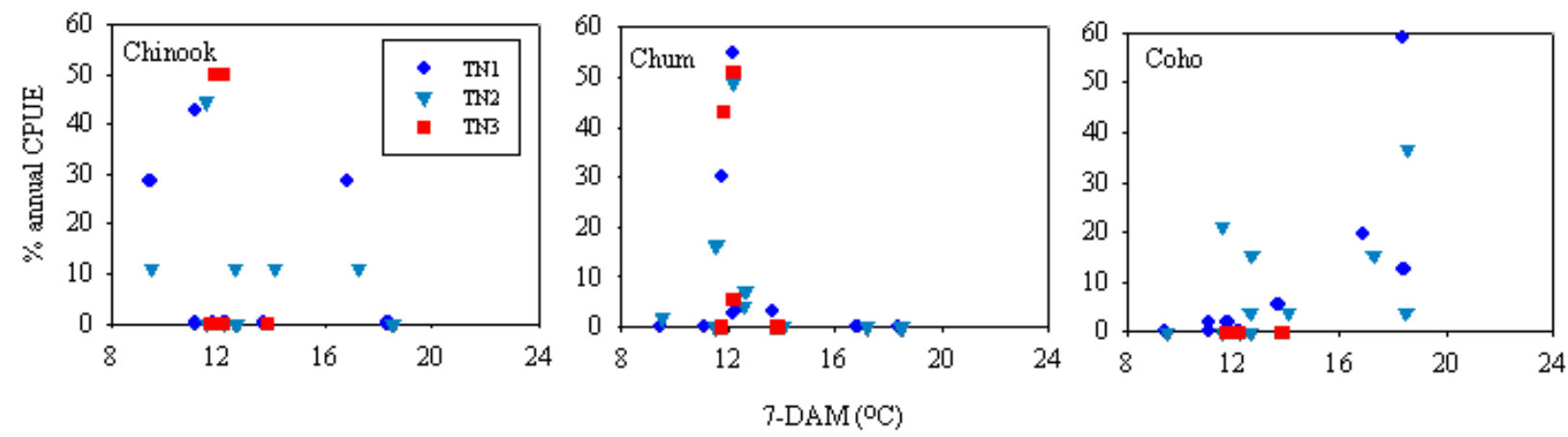

Figure 2.5. Salmon Relative Annual Abundance Versus 7-DAM Temperature, 2009 (TN = trap net)

\subsection{Vegetation-Elevation}

\section{Prepared by Heida Diefenderfer, Amy Borde, Shon Zimmerman, Ron Kauffman, and Amanda Bryson}

This section summarizes 2009 field work to collect data on vegetation and elevation at the Kandoll, Vera, Crims restoration sites and their associated reference sites. Four categories of data are included: plant cover, plant species elevations, sediment accretion rates, and channel cross sections. The methods are described by Roegner et al. (2009a), and additional information about channel cross-section and elevation surveys at these sites can be found in the article by Diefenderfer et al. (2008). 


\subsubsection{Plant Cover and Elevation}

\subsubsection{Herbaceous Cover}

Herbaceous plant cover and elevation were sampled at all sites. The plant species cover and elevation range are grouped for each restoration and reference pair, for the purpose of comparison, in Figures 2.6, 2.7, and 2.8. At Vera Slough, the wetland behind the tide-gate replacement was substantially lower than the reference site and it was dominated by bare ground, while the reference site was dominated by Carex lyngbei (Lyngbye's sedge). Kandoll restoration and reference sites also showed little similarity between cover, with plant species in the reference site typically located at higher elevations than the restoration site, with some notable exceptions. Kandoll Farm was dominated by Phalaris arundinacea (reed canarygrass). At the reference site (a swamp), there was relatively more bare ground, litter, and moss, and Lysichiton americanus (Western skunk cabbage). Crims restoration and reference sites have very similar elevations. Crims Island was graded, whereas Kandoll Farm and Vera Slough are in transition toward a new plant community with sediment accretion still occurring (see "Sediment Accretion" section below). Plant communities are very different at the Crims restoration and reference sites. The restoration site is dominated by Phalaris arundinacea and Juncus effuses (common rush). The reference site is dominated by Carex obnupta (slough sedge) and Myosotis species (forget-me-not).

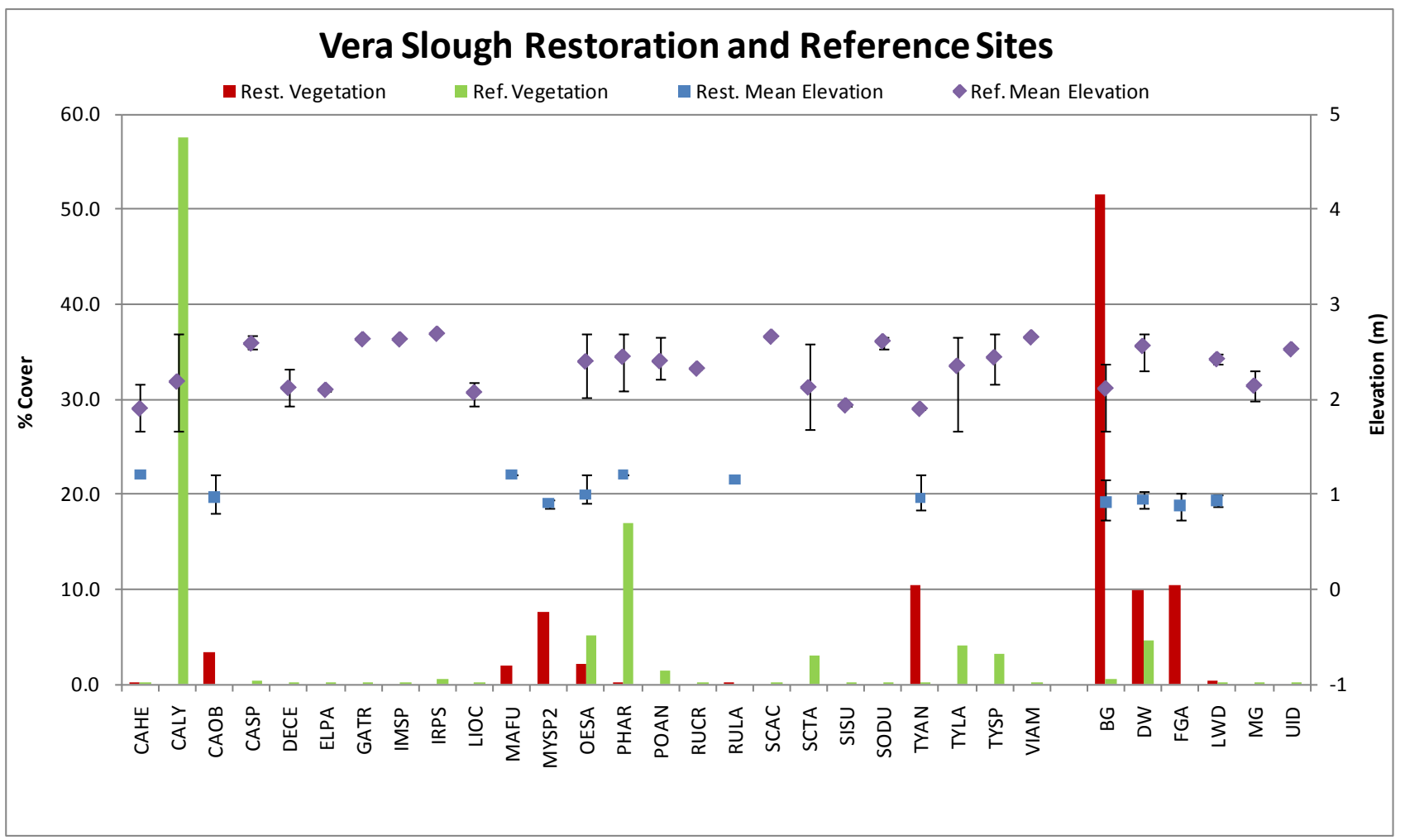

Figure 2.6. Herbaceous Vegetation Cover and Species Elevation Ranges at Vera Slough Restoration and Reference Sites During 2009. BG = bare ground, DW = debris wrack, FGA = filamentous green algae, LWD = large woody debris, MG = mixed grass, UID = unidentified. Four-letter species codes in these figures represent the first two letters of the genus and species. 


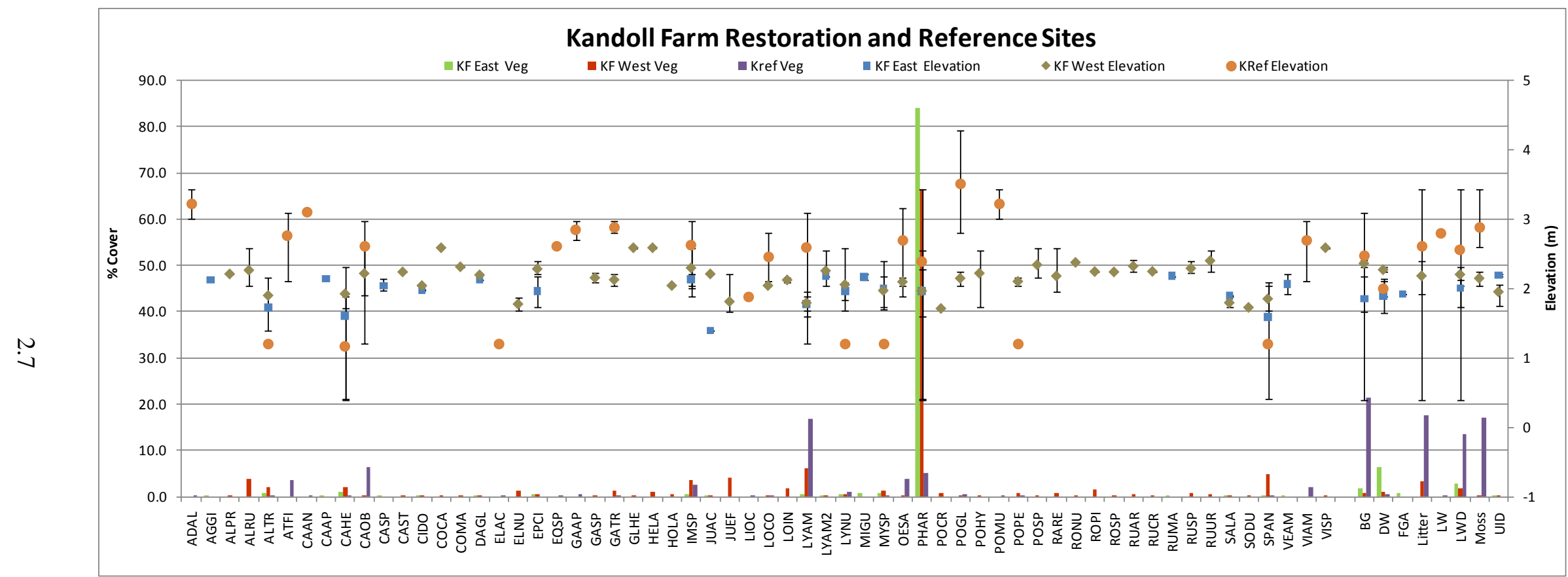

Figure 2.7. Herbaceous Vegetation Cover and Species Elevation Ranges at Kandoll Farm Restoration and Reference Sites During 2009. $\mathrm{BG}=$ bare ground, $\mathrm{DW}=$ debris wrack, $\mathrm{FGA}=$ filamentous green algae, $\mathrm{LWD}=$ large woody debris, $\mathrm{MG}=$ mixed grass, UID = unidentified. 


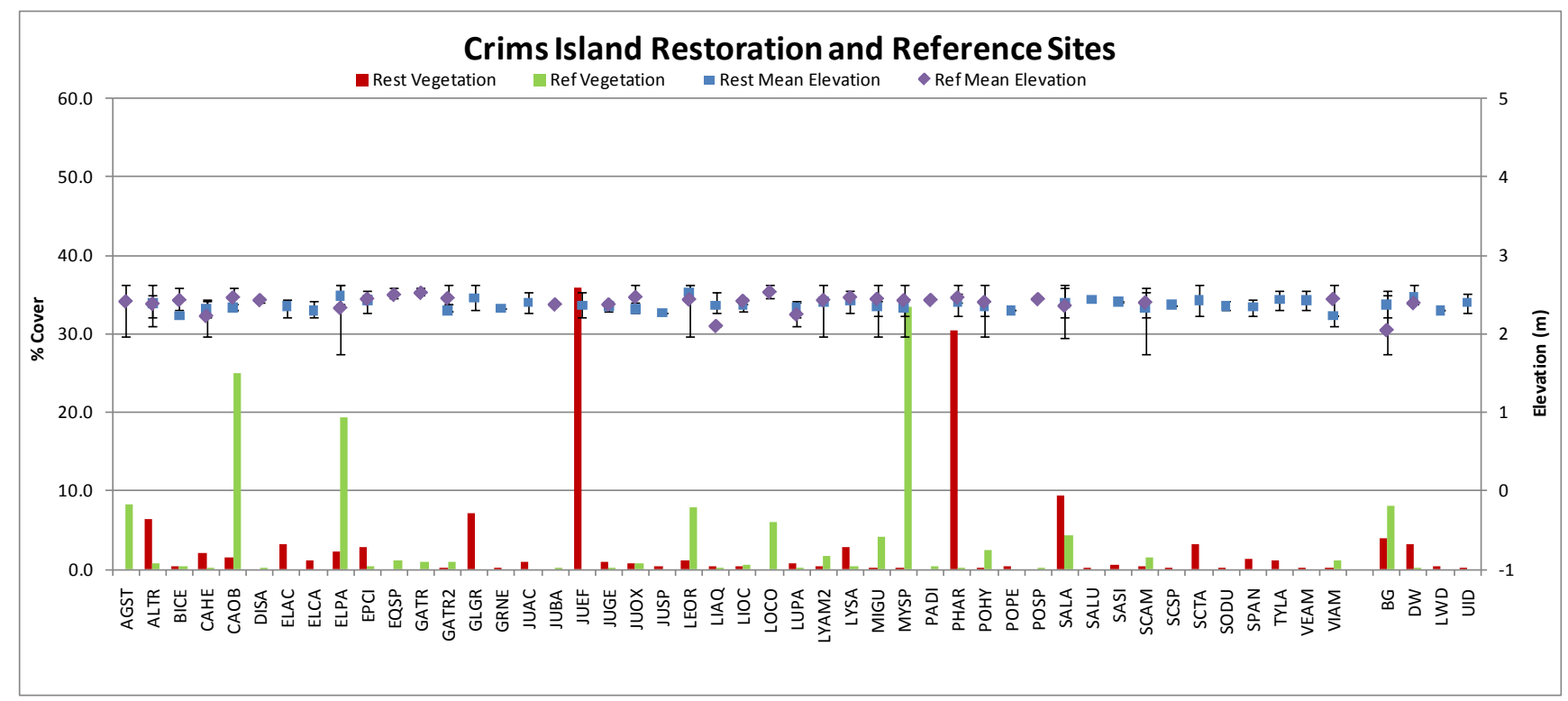

Figure 2.8. Herbaceous Vegetation Cover and Species Elevation Ranges at Crims Island Restoration and Reference Sites During 2009. BG = bare ground, DW = debris wrack, FGA = filamentous green algae, LWD = large woody debris, MG = mixed grass, UID = unidentified.

\subsubsection{Shrub Density}

Of the three restoration sites and their associated reference sites, shrubs were sampled only at the Kandoll reference site (Table 2.1). Following Peet et al. (1998) as described by Roegner et al. (2009a), stems were counted at 1.4-m height and identified to species and size class in a $1 \times 10$-m belt, and individual stems were defined as follows: "Multiple stems arising from a common root system are recorded separately if they branch below $0.5 \mathrm{~m}$ above ground level (stems branching above $0.5 \mathrm{~m}$ and below $1.4 \mathrm{~m}$ are measured at the narrowest point below the branch).” The most frequently present species were Rubus spectabilis (salmonberry), Rubus ursinus (trailing blackberry), and Corus sericea L. ssp. sericea (red osier dogwood, formerly Cornus stolonifera). Two shrubs had higher densities greater than 18\%, substantially higher than any others: Rubus spectabilis and Gaultheria shallon (salal); the latter is typically associated with mounds around Picea sitchensis (Sitka spruce) trees. Three shrubs are typically associated with the higher hummocks of the swamp, where Picea sitchensis trees also occur, as seen by their elevations (Table 2.1): Acer circinatum (vine maple), Gaultheria shallon (salal), and Vaccinium parvifolium (red huckleberry).

To compare the abundance of different shrub species, relative frequency percent and relative density percent are reported in Table 2.1. Relative frequency percent is the ratio of the proportion of plots in which a species occurs to the overall frequency (sum of frequencies of all species); similarly, relative density percent is the ratio of the density of one species to the sum of densities of all species (McCune and Grace 2002). While frequency is a useful descriptor of the spatial distribution of a species, it is dependent on the size of the sample unit; density, the number of individuals per unit area, is not dependent on the size of the sampling unit (McCune and Grace 2002). Both ways of looking at abundance can be useful for shrubs. 
Table 2.1. Summary of 2009 Shrub Stem Frequency, Density, and Elevation at the Kandoll Reference Swamp

\begin{tabular}{lcccc}
\hline \multicolumn{1}{c}{ Species } & $\begin{array}{c}\text { Density (stems } \\
\text { per hectare) }\end{array}$ & $\begin{array}{c}\text { Relative } \\
\text { Frequency } \%\end{array}$ & $\begin{array}{c}\text { Relative } \\
\text { Density \% }\end{array}$ & $\begin{array}{c}\text { Mean Elevation } \\
\text { (m, NAVD88) }\end{array}$ \\
\hline Acer circinatum & 200 & 2.8 & 0.3 & 3.99 \\
Amelanchier alnifolia & 2400 & 1.4 & 3.8 & ND \\
Cornus sericea & 6200 & 12.7 & 9.8 & 3.00 \\
Gaultheria shallon & 11500 & 9.9 & 18.1 & 3.30 \\
Lonicera involucrata & 3700 & 8.5 & 5.8 & 2.85 \\
Oemleria cerasiformis & 100 & 1.4 & 0.2 & ND \\
Physocarpus capitatus & 5600 & 9.9 & 8.8 & 3.13 \\
Ribes divaricatum & 1500 & 1.4 & 2.4 & 2.75 \\
Ribes lacustre & 1000 & 2.8 & 1.6 & 2.82 \\
Rosa nutkana & 2400 & 11.3 & 3.8 & 2.87 \\
Rubus parviflorus & 8300 & 8.5 & 13.1 & 3.27 \\
Rubus spectabilis & 11600 & 14.1 & 18.3 & 3.06 \\
Rubus ursinus & 6900 & 12.7 & 10.9 & 3.07 \\
Spiraea douglasii & 2100 & 2.8 & 3.3 & 2.70 \\
Vaccinium parvifolium & 600 & 4.2 & 0.9 & 3.45 \\
Unidentified & 200 & 1.4 & 0.3 & ND \\
\hline NAVD88 = North American Vertical Datum of 1988 ND $=$ No data available. & & \\
\hline
\end{tabular}

\subsubsection{Tree Cover}

The swamp at the Kandoll reference site is characterized by Sitka spruce as the dominant tree (Table 2.2), and Thuja plicata (Western redcedar) as the subdominant. Dominance is the aggregate basal area of trees in a stand, and is the measure of species abundance that is most closely proportional to leaf area and foliage mass (McCune and Grace 2002). Malus fusca (Pacific crabapple) exhibits the highest relative frequency percent and relative density percent (these metrics are defined in the previous section). The $0.9 \%$ relative dominance of Malus fusca illustrates the less useful aspect of the density metric for trees because of their great size variability (McCune and Grace 2002). Another small tree, Frangula purshiana (Pursch's buckthorn), has low dominance despite its frequency and density. Very similar roles in the overstory composition are played by Alnus rubra (red alder) and Fraxinus latifolia (Oregon ash). The abundance of Tsuga heterophylla (Western hemlock) is low and plots with no trees have a relative frequency percent of 4.7 .

\subsubsection{Mini-Mega Transect}

The mini-mega transect across the Kandoll restoration site was surveyed using a line-intercept method in 2005, 2006, and 2009. Table 2.3a shows the number of points in each of the five fields that were occupied by each species, using the four-letter species codes described above. If more than one layer of vegetation, that is more than one species, was present at a given point then all layers were recorded; thus, the number of points in a given row does not necessarily add up to the total number of points in that field. Table 2.3b shows the presence of 25 new species in the 2009 survey. This substantial increase in species richness occurred since the dike breaches and culvert replacements in 2005. 
Table 2.2. Summary of 2009 Tree Cover at the Kandoll Reference Swamp

\begin{tabular}{|c|c|c|c|c|c|c|c|c|}
\hline Species & $\begin{array}{c}\text { Relative } \\
\text { Frequency } \\
\% \\
\end{array}$ & $\begin{array}{c}\text { Relative } \\
\text { Density } \\
\% \\
\end{array}$ & $\begin{array}{c}\text { Relative } \\
\text { Dominance } \\
\% \\
\end{array}$ & $\begin{array}{l}\mathrm{dbh} \\
\mathrm{min} \\
(\mathrm{cm})\end{array}$ & $\begin{array}{l}\mathrm{dbh} \\
\max \\
(\mathrm{cm})\end{array}$ & $\begin{array}{l}\text { Mean } \\
\text { dbh } \\
(\mathrm{cm})\end{array}$ & $\begin{array}{l}\text { Median } \\
\text { dbh } \\
(\mathrm{cm})\end{array}$ & $\begin{array}{c}\text { Mean } \\
\text { Elevation } \\
\text { (m, NAVD88) }\end{array}$ \\
\hline Alnus rubra & 10.9 & 9.8 & 10.7 & 1.0 & 60.5 & 20.3 & 13.9 & 3.01 \\
\hline $\begin{array}{l}\text { Fraxinus } \\
\text { latifolia }\end{array}$ & 10.9 & 7.0 & 11.0 & 1.0 & 78.3 & 19.5 & 11.5 & 3.35 \\
\hline Malus fusca & 23.4 & 38.5 & 0.9 & 1.0 & 11.0 & 3.1 & 2.2 & 3.02 \\
\hline $\begin{array}{l}\text { Picea } \\
\text { sitchensis }\end{array}$ & 20.3 & 22.4 & 57.3 & 1.0 & 79.9 & 28.9 & 21.2 & 3.74 \\
\hline $\begin{array}{l}\text { Frangula } \\
\text { purshiana }\end{array}$ & 15.6 & 12.6 & 1.3 & 1.0 & 14.7 & 6.4 & 5.1 & 3.68 \\
\hline Thuja plicata & 10.9 & 7.0 & 16.9 & 6.9 & 96.3 & 27.8 & 16.5 & 3.65 \\
\hline $\begin{array}{l}\text { Tsuga } \\
\text { heterophylla }\end{array}$ & 3.1 & 2.8 & 2.0 & 17.2 & 29.0 & 20.4 & 17.7 & 3.77 \\
\hline No trees & 4.7 & NA & NA & NA & NA & NA & NA & \\
\hline
\end{tabular}

\subsubsection{Sediment Accretion}

Sediment accretion rates at Vera Slough were high $(3.2 \mathrm{~cm} / \mathrm{yr})$ after tide-gate replacement (between 2005 and 2007) and decreased by 2009 to a cumulative rate of $1.2 \mathrm{~cm} / \mathrm{yr}$ (Table 2.4). Rates at the Vera reference sites were substantially less, and while one showed a decline of about half between 2007 and 2009 assessments, the other increased slightly. These reference rates serve as an environmental control for the restoration site. They indicate that the extreme initial sediment accretion rate and the declining but still high rate after 4 years are caused by the tide-gate replacement.

At Crims Island, where restoration actions were completed in 2005, the restoration site also exhibited higher accretion rates than the reference site, but there was little difference between the assessments conducted from 2006 through 2009 and 2008 through 2009 (1.4 versus $1.5 \mathrm{~cm} / \mathrm{yr}$ ). Accretion rates assessed at the reference site were $1.0 \mathrm{~cm} / \mathrm{yr}$ from 2006 to 2009 and $0.4 \mathrm{~cm} / \mathrm{yr}$ from 2008 to 2009 at a different set of stakes.

Figure 2.9 contrasts the accretion rate at swamp reference sites with restoration sites. The mean 2008-2009 sediment accretion rate from 12 pairs of sediment accretion stakes at 4 swamp sites (including 3 in the vicinity of Grays Bay and one on a main stem Columbia River island) was $0.5 \mathrm{~cm} / \mathrm{yr}$ (s.d. 0.6). The mean sediment accretion rate from five pairs of sediment accretion stakes at two restoration sites on the Grays River - three monitored between 2005 and 2007 and two monitored between 2005 and 2009_was $2.3 \mathrm{~cm} / \mathrm{yr}$ (s.d. 0.3). In interpreting this finding, it must be cautioned that these restoration sites are located on the Grays River system, which has an unnatural sediment load (May and Geist 2007), although as described above, the rates at the Vera restoration site on Youngs Bay were even higher than these rates. In contrast to Vera Slough, uniform decline in accretion rates between the 2007 and 2009 assessments were not seen in the swamp restoration sites. 
Table 2.3a. Plant Species on a Line-Intercept Transect in Five Fields at Kandoll Farm in 2005, 2006, and 2009

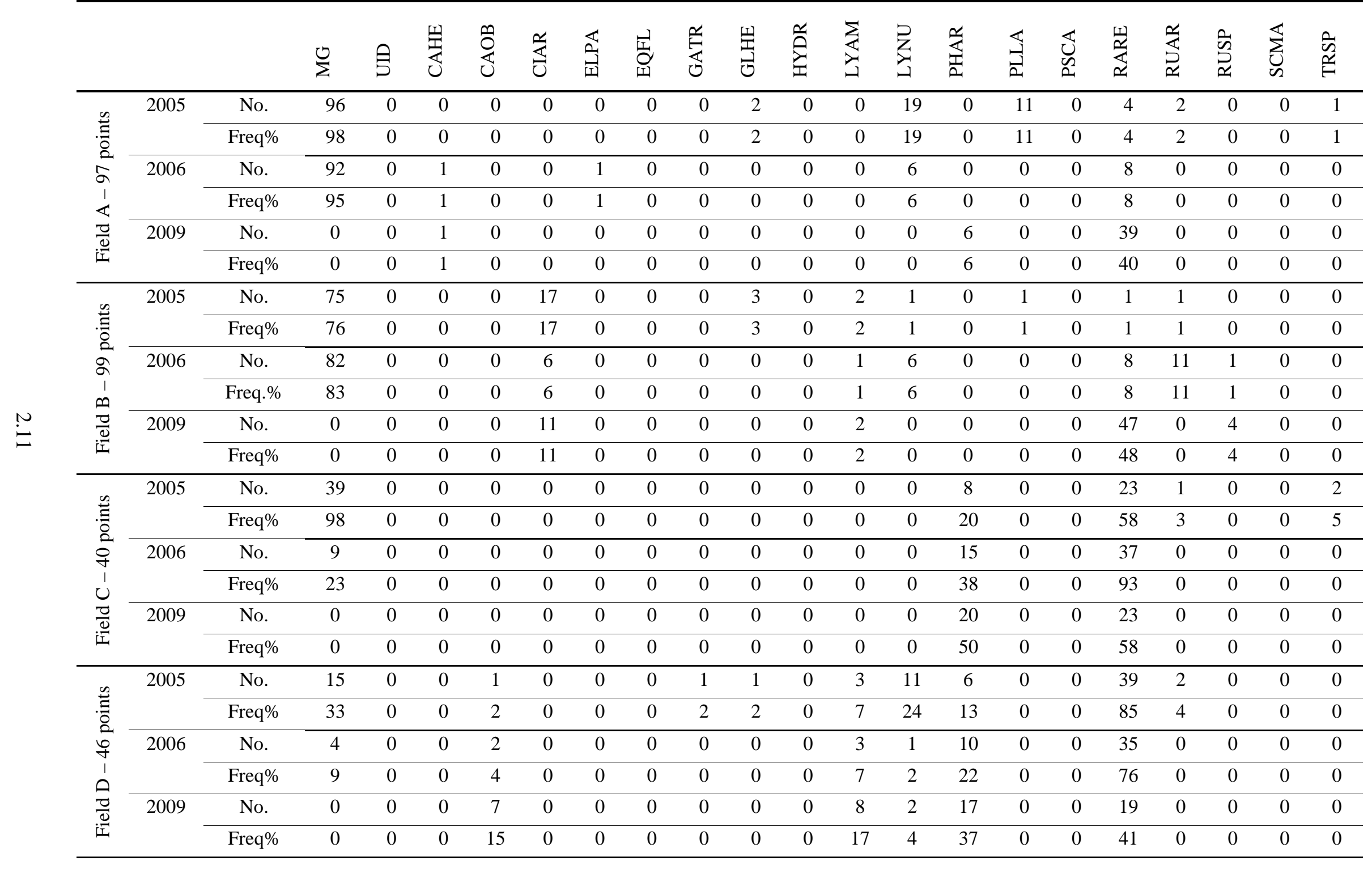


Table 2.3a. (contd)

\begin{tabular}{|c|c|c|c|c|c|c|c|c|c|c|c|c|c|c|c|c|c|c|c|c|c|c|}
\hline & & & $\sum_{\Sigma}^{U}$ & 合 & 岕 & 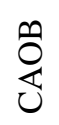 & 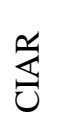 & 吕 & 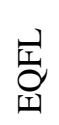 & 岕 & 㳫 & 只 & 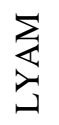 & 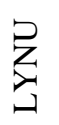 & 蛋 & 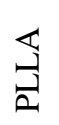 & $\begin{array}{l}\mathbb{U} \\
\mathscr{n}\end{array}$ & 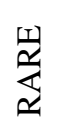 & 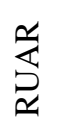 & $\begin{array}{l}\text { صे } \\
\text { 足 }\end{array}$ & 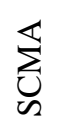 & 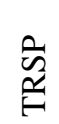 \\
\hline \multirow{6}{*}{ 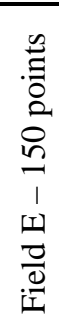 } & \multirow{2}{*}{2005} & No. & 103 & 0 & 0 & 0 & 0 & 0 & 0 & 0 & 1 & 0 & 8 & 16 & 57 & 0 & 0 & 25 & 0 & 0 & 0 & 2 \\
\hline & & Freq.\% & 68 & 0 & 0 & 0 & 0 & 0 & 0 & 0 & 1 & 0 & 5 & 11 & 38 & 0 & 0 & 17 & 0 & 0 & 0 & 1 \\
\hline & \multirow[t]{2}{*}{2006} & No. & 20 & 4 & 0 & 0 & 0 & 1 & 1 & 1 & 0 & 8 & 3 & 0 & 95 & 0 & 1 & 22 & 0 & 0 & 8 & 0 \\
\hline & & Freq\% & 13 & 3 & 0 & 0 & 0 & 1 & 1 & 1 & 0 & 5 & 2 & 0 & 63 & 0 & 1 & 15 & 0 & 0 & 5 & 0 \\
\hline & \multirow[t]{2}{*}{2009} & No. & 2 & 0 & 0 & 0 & 0 & 0 & 0 & 0 & 0 & 0 & 11 & 2 & 120 & 0 & 0 & 8 & 2 & 0 & 0 & 0 \\
\hline & & Freq\% & 1 & 0 & 0 & 0 & 0 & 0 & 0 & 0 & 0 & 0 & 7 & 1 & 80 & 0 & 0 & 5 & 1 & 0 & 0 & 0 \\
\hline
\end{tabular}

Table 2.3b. Presence of Previously Unrecorded Species in Five Fields on a Line-Intercept Transect at Kandoll Farm in 2009

\begin{tabular}{|c|c|c|c|c|c|c|c|c|c|c|c|c|c|c|c|c|c|c|c|c|c|c|c|c|c|c|c|}
\hline 프 & & \begin{tabular}{l}
0 \\
Dू \\
\multirow{2}{*}{}
\end{tabular} & $\begin{array}{l}\text { 点 } \\
\text { 娄 }\end{array}$ & 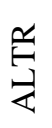 & 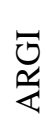 & $\underset{\mho}{\mathbb{U}}$ & 足 & 家 & 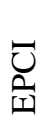 & 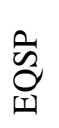 & 芯 & 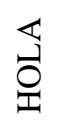 & $\sum_{i}^{\tilde{n}}$ & 导 & 妄 & 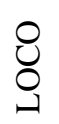 & 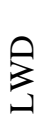 & 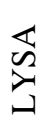 & 岕 & $\begin{array}{l}\text { 空 } \\
\text { ○ }\end{array}$ & $\begin{array}{l}\text { थे } \\
\text { ญे }\end{array}$ & 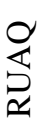 & 号 & 离 & $\sum_{\mathcal{W}}$ & 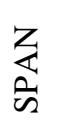 & $\sum_{\substack{5 \\
>}}$ \\
\hline \multirow{2}{*}{$A$} & No. & 0 & 71 & 4 & 0 & 1 & 0 & 4 & 2 & 0 & 0 & 5 & 0 & 2 & 13 & 4 & 1 & 0 & 0 & 0 & 0 & 0 & 1 & 2 & 3 & 10 & 0 \\
\hline & Freq\% & 0 & 73 & 4 & 0 & 1 & 0 & 4 & , & 0 & 0 & 5 & 0 & 2 & 13 & 4 & 1 & 0 & 0 & 0 & 0 & 0 & 1 & 2 & 3 & 10 & 0 \\
\hline \multirow{2}{*}{ B } & No. & 2 & 19 & 0 & 21 & 2 & 0 & 0 & 0 & 1 & 2 & 11 & 11 & 0 & 0 & 36 & 1 & 0 & 3 & 0 & 2 & 1 & 0 & 1 & 0 & 0 & 0 \\
\hline & Freq\% & 2 & 20 & 0 & 22 & 2 & 0 & 0 & 0 & 1 & 2 & 11 & 11 & 0 & 0 & 37 & 1 & 0 & 3 & 0 & 2 & 1 & 0 & 1 & 0 & 0 & 0 \\
\hline \multirow{2}{*}{ C } & No. & 0 & 4 & 0 & 0 & 0 & 0 & 0 & 0 & 0 & 0 & 3 & 0 & 0 & 2 & 0 & 0 & 0 & 0 & 0 & 0 & 0 & 0 & 0 & 0 & 0 & 0 \\
\hline & Freq\% & 0 & 10 & 0 & 0 & 0 & 0 & 0 & 0 & 0 & 0 & 8 & 0 & 0 & 5 & 0 & 0 & 0 & 0 & 0 & 0 & 0 & 0 & 0 & 0 & 0 & 0 \\
\hline \multirow{2}{*}{ D } & No. & 0 & 0 & 0 & 0 & 0 & 0 & 0 & 0 & 0 & 9 & 0 & 10 & 0 & 22 & 4 & 0 & 0 & 0 & 0 & 0 & 0 & 0 & 0 & 0 & 0 & 0 \\
\hline & Freq\% & 0 & 0 & 0 & 0 & 0 & 0 & 0 & 0 & 0 & 20 & 0 & 22 & 0 & 48 & 9 & 0 & 0 & 0 & 0 & 0 & 0 & 0 & 0 & 0 & 0 & 0 \\
\hline \multirow{2}{*}{ E } & No. & 0 & 9 & 0 & 0 & 0 & 2 & 0 & 0 & 0 & 5 & 0 & 20 & 0 & 14 & 1 & 0 & 1 & 0 & 1 & 0 & 0 & 4 & 1 & 15 & 0 & 2 \\
\hline & Freq\% & 0 & 6 & 0 & 0 & 0 & 1 & 0 & 0 & 0 & J & 0 & 13 & 0 & 9 & 1 & 0 & 1 & 0 & 1 & 0 & 0 & 3 & 1 & 10 & 0 & 1 \\
\hline
\end{tabular}


Table 2.4. Summary of Sediment Accretion Rates at Paired Restoration and Reference Sites. Blank space implies no data.

\begin{tabular}{|c|c|c|c|c|}
\hline Site Code & $\begin{array}{l}\text { 2005-2009 Rate } \\
(\mathrm{cm} / \mathrm{yr})\end{array}$ & $\begin{array}{l}\text { 2005-2007 Rate } \\
\text { (cm/yr) }\end{array}$ & $\begin{array}{l}\text { 2006-2009 Rate } \\
(\mathrm{cm} / \mathrm{yr})\end{array}$ & $\begin{array}{l}\text { 2008-2009 Rate } \\
\text { (cm/yr) }\end{array}$ \\
\hline $\mathrm{CC}$ & & & & 0.0 \\
\hline CI & & & 1.4 & 1.5 \\
\hline GI (new) & & & & 0.4 \\
\hline GI (old) & & & 1.0 & \\
\hline GRD & 2.7 & 3.5 & & \\
\hline $\mathrm{J} 1$ & & 2.2 & & \\
\hline $\mathrm{J} 2$ & & 2.3 & & \\
\hline $\mathrm{J} 3$ & & 1.8 & & \\
\hline KFE & $2.4^{(\mathrm{a})}$ & 1.3 & & \\
\hline KFW & $0.7^{(\mathrm{b})}$ & 3.1 & & \\
\hline KIS & & & & 0.3 \\
\hline KR 1-1 & & & 0.1 & 0.2 \\
\hline KR 1-2 & & & 0.7 & 0.4 \\
\hline KR 1-3 & & & & -0.1 \\
\hline KR 2A & & & 1.0 & 1.5 \\
\hline KR 2B & & & & 0.1 \\
\hline KR 2C & & & & 0.4 \\
\hline KR 3A & & & & 1.7 \\
\hline KR 3B & & & & 0.2 \\
\hline KR 3C & & & & 1.2 \\
\hline SR & & & & 0.5 \\
\hline VRN & 0.3 & 0.6 & & \\
\hline VRS & 0.6 & 0.5 & & \\
\hline VS & 1.2 & 3.2 & & \\
\hline \multicolumn{5}{|c|}{$\begin{array}{l}\text { (a) In 2009, the stake had been battered by large woody debris and lost; measurement was estimated from only on } \\
\text { stake. } \\
\text { (b) The data are unusable for comparison with other results, because of measurement in a mat of Phalaris } \\
\text { arundinacea. }\end{array}$} \\
\hline
\end{tabular}




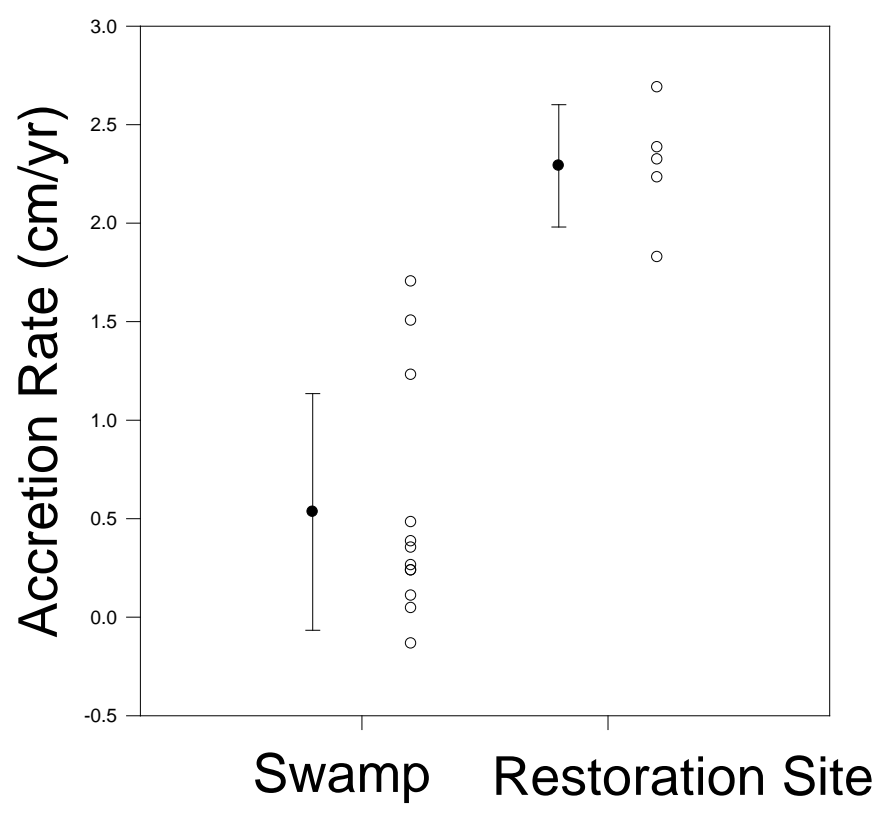

Figure 2.9. Comparison of Sediment Accretion Rates at Reference Swamps and Restoration Sites. The open circles are the data point and the black circles are the mean with error bars for the standard deviation.

\subsubsection{Cross Sections}

The figures in this section document the 2009 cross-sectional area, shape, and depth relative to surveys before restoration and enhancement actions and in some intervening years. Figure 2.10 and Figure 2.11 show Vera restoration and reference sites, respectively; Figure 2.12 shows Kandoll Reference site; Figure 2.13 and Figure 2.14 show dike breaches along the Grays River at Kandoll Farm; Figure 2.15 shows Seal Slough above the culvert replacement on Kandoll Farm; and Figure 2.16 shows Crims Island.

As described by Diefenderfer et al. (2008), several trends have remained consistent throughout the 2009 surveys:

- The largest rate of change is seen in the cross sections located most proximal to the restoration action (e.g., Figure 2.10, Vera Slough Dike Outside and Figure 2.15, Seal Slough Inside).

- A general pattern of accretion, with two of three cases having very small incisions at the thalweg, are seen at dike breach cross sections with very small contributing channel areas (Figure 2.13).

- The small incisions and/or increases in cross-sectional areas seen up-channel from restoration actions in some cases (e.g., Figure 2.10, Figure 2.14, Figure 2.15) most likely are morphological responses to the need to convey increased flow volumes associated with subsidence of the sites during diked years, but these flows are expected to lessen as the sites accrete (see preceding section) and the tidal prism correspondingly decreases.

- Reference sites trend toward accretion, and explanations accounting for this include the beaver activity at the upper Kandoll reference site (Figure 2.12) and the closing of the tide gate and subsequent stagnation of the Vera Slough reference site (Figure 2.11).

- It is unknown why the central transect at the Kandoll reference site is accreting (Figure 2.12). 

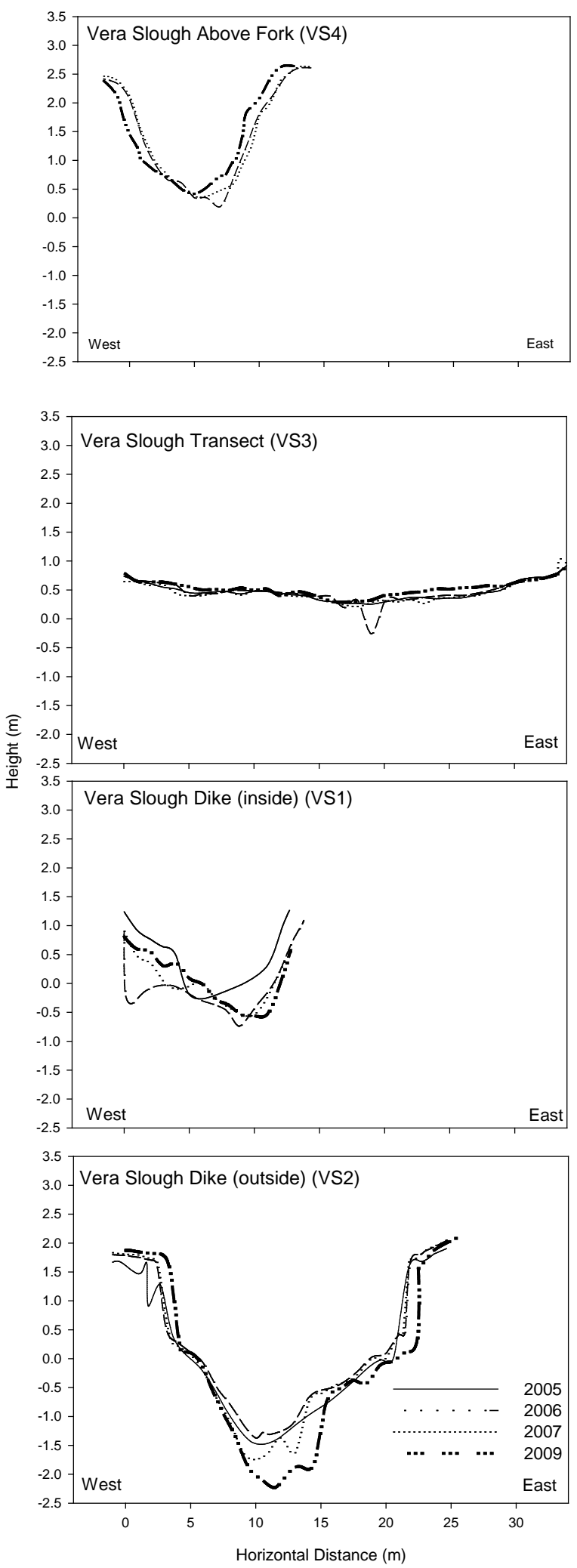

Figure 2.10. Channel Cross Sections Before and After Tide-Gate Replacement at the Vera Slough Restoration Site 


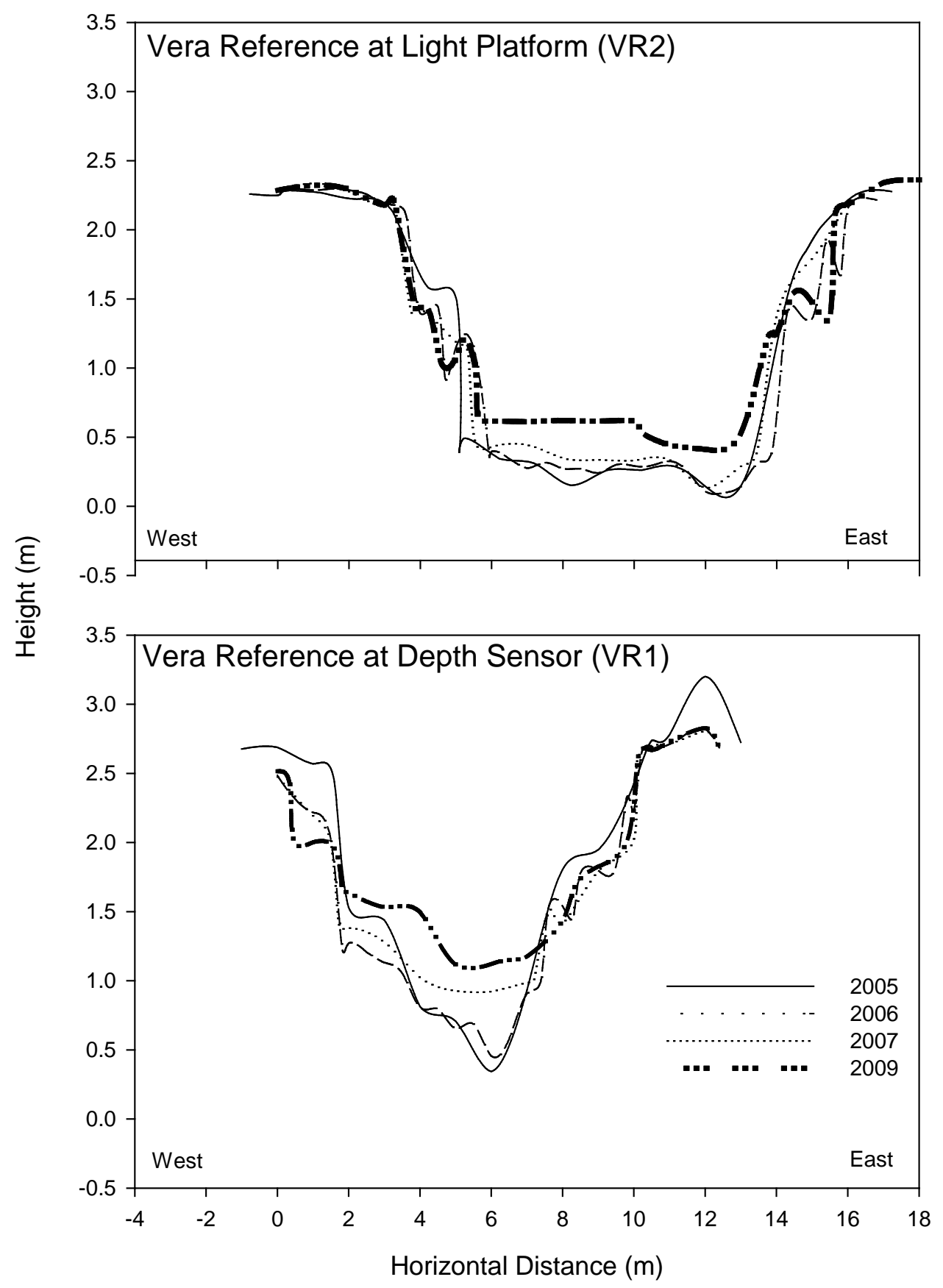

Figure 2.11. Channel Cross Sections at the Vera Slough Reference Site 


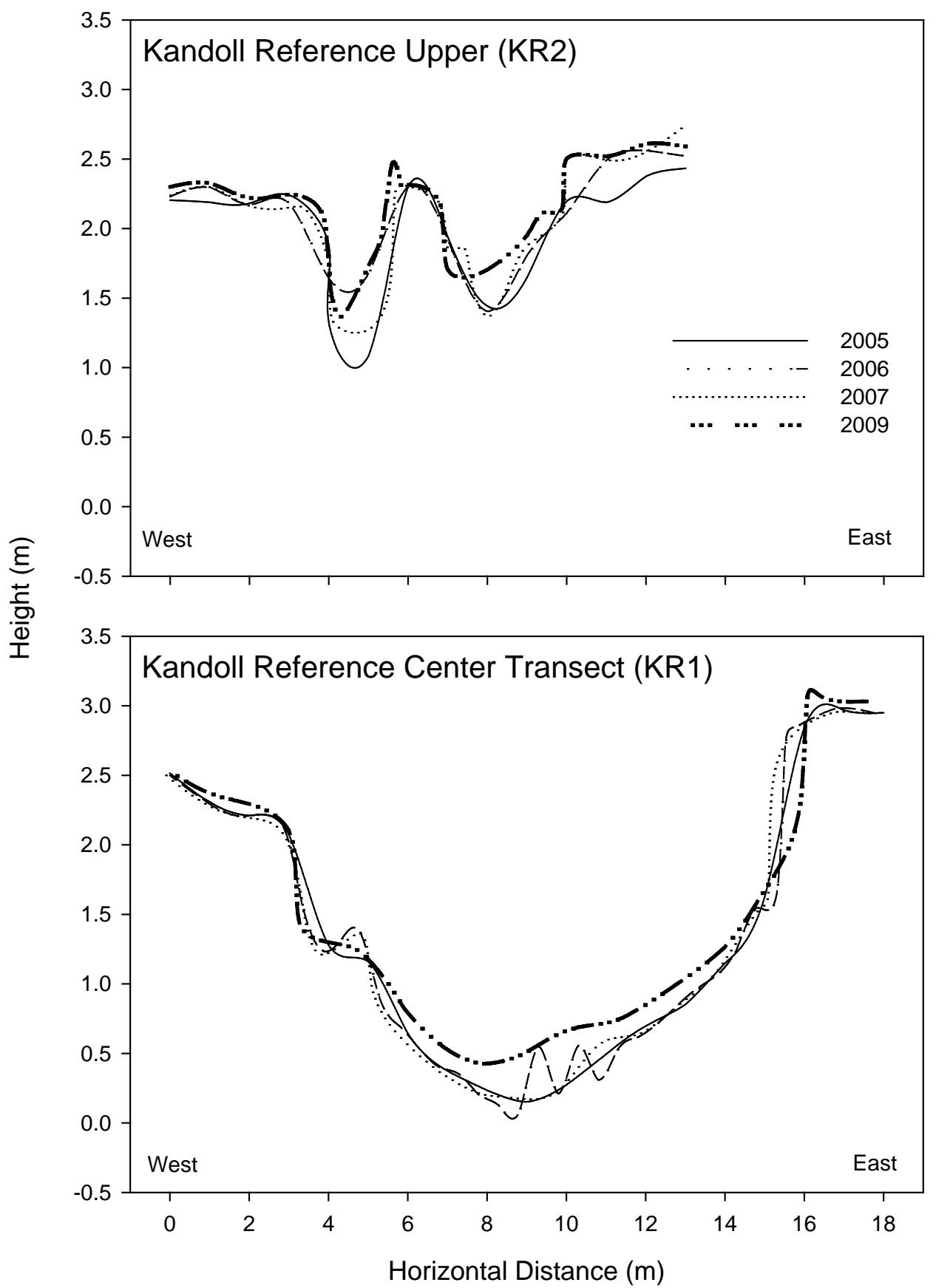

Figure 2.12. Cross Sections at a Reference Channel Before and After Nearby Restoration and Enhancement Actions at Kandoll Farm. Note: The KR2 channel is split by a hummock. 

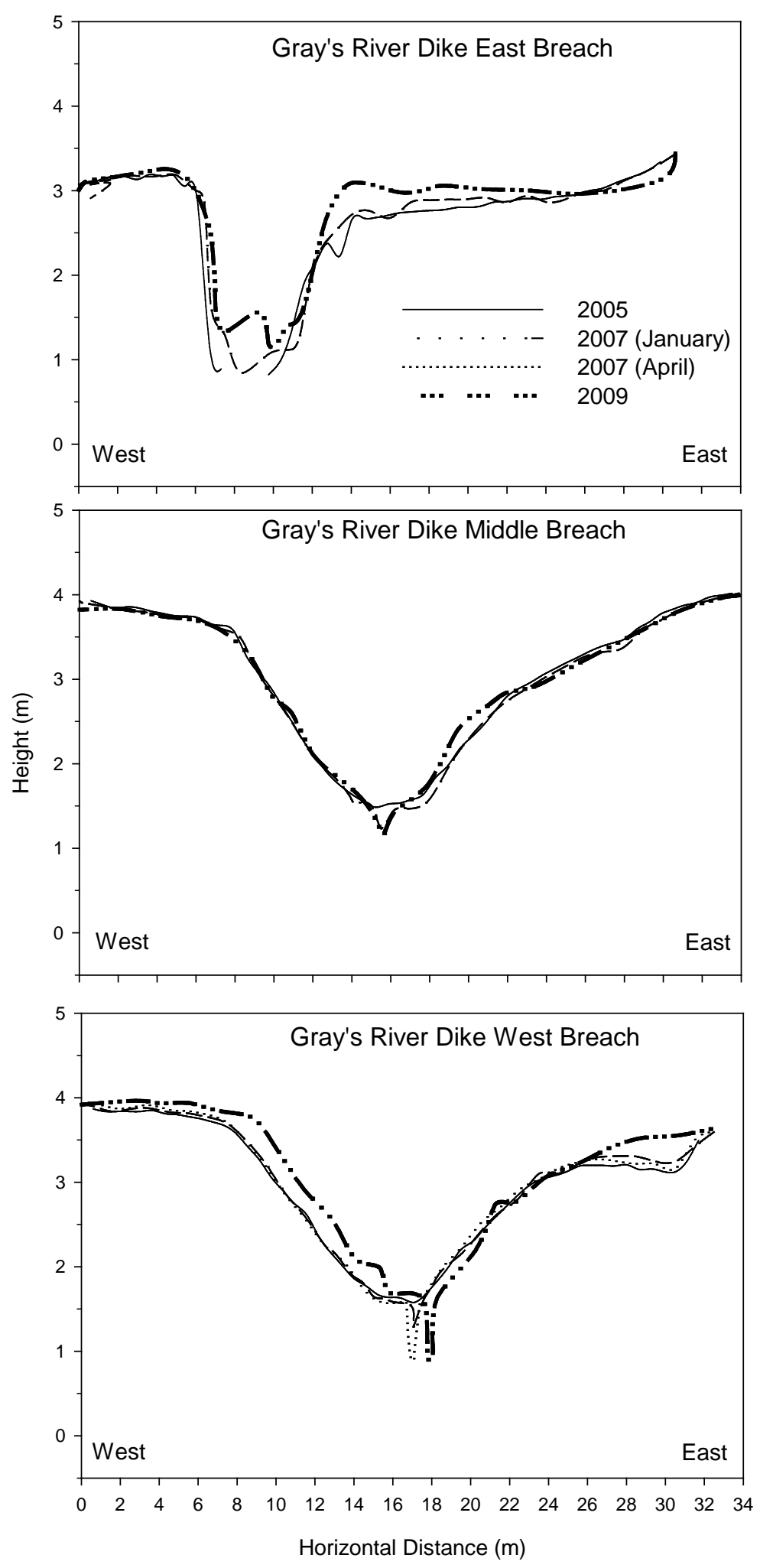

Figure 2.13. Three Dike Breaches on the Grays River at Kandoll Farm, 2005-2009. Data in 2005 are from as-built surveys after excavation of the breaches. 

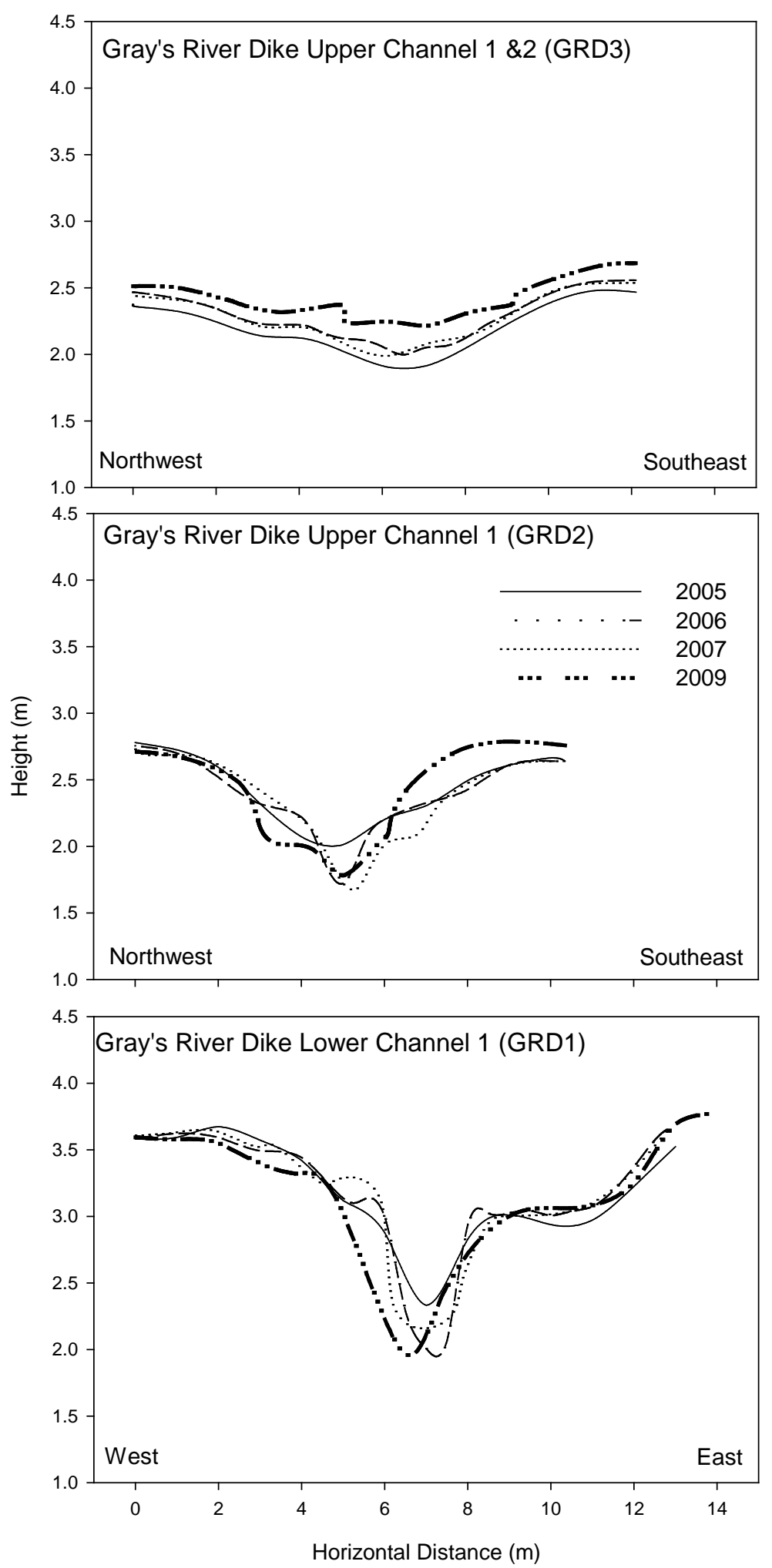

Figure 2.14. Channel Cross Sections on One Channel on the Grays River at Kandoll Farm, Before and After the Dike at Its Mouth Was Breached 

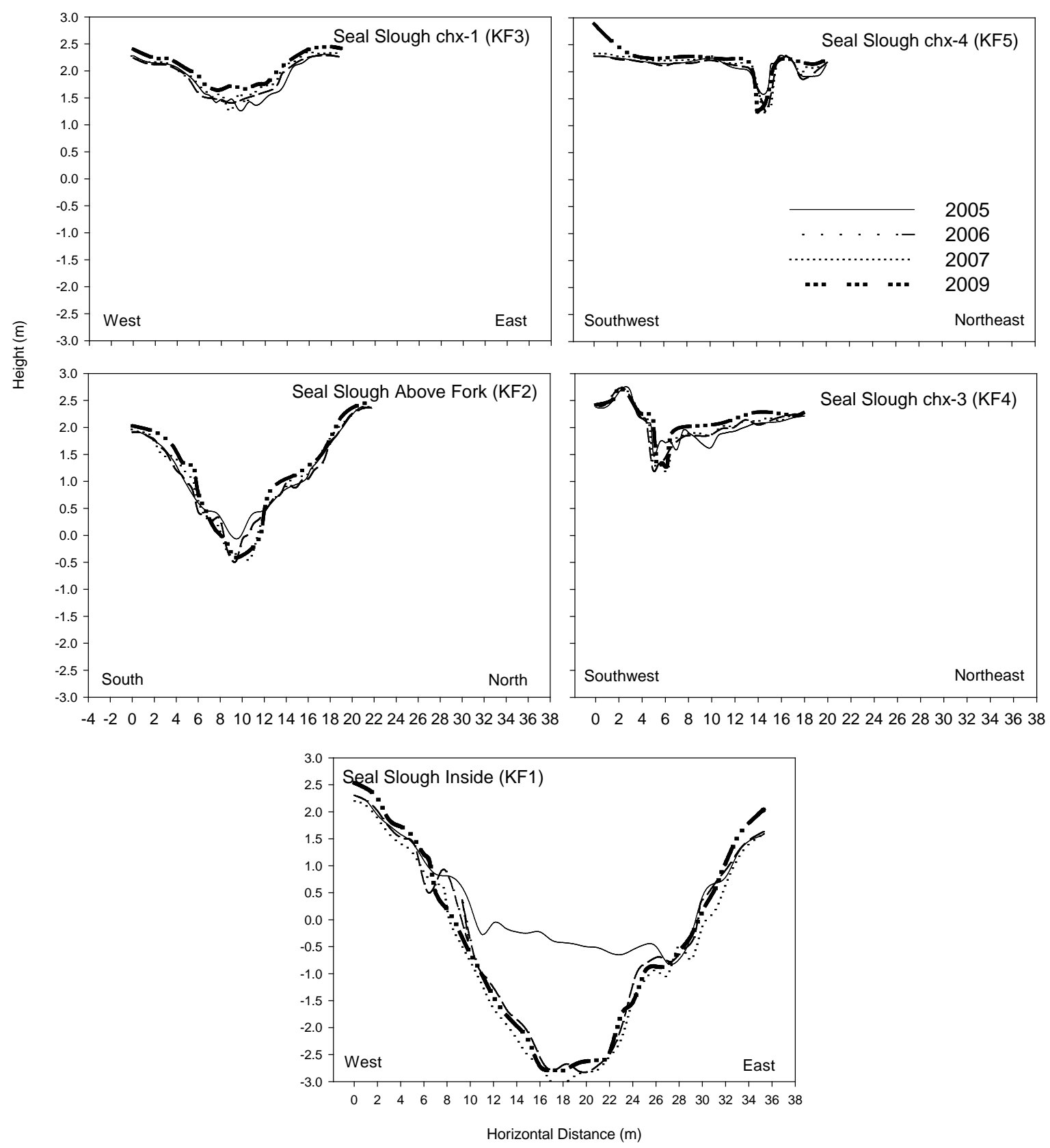

Figure 2.15. Cross Sections at Five Locations on Upper Seal Slough in Kandoll Farm. Cross sections are oriented such that the most downstream survey at the culvert replacement is in the lowest position, with the two main forks of Seal Slough above that to the right and left. 


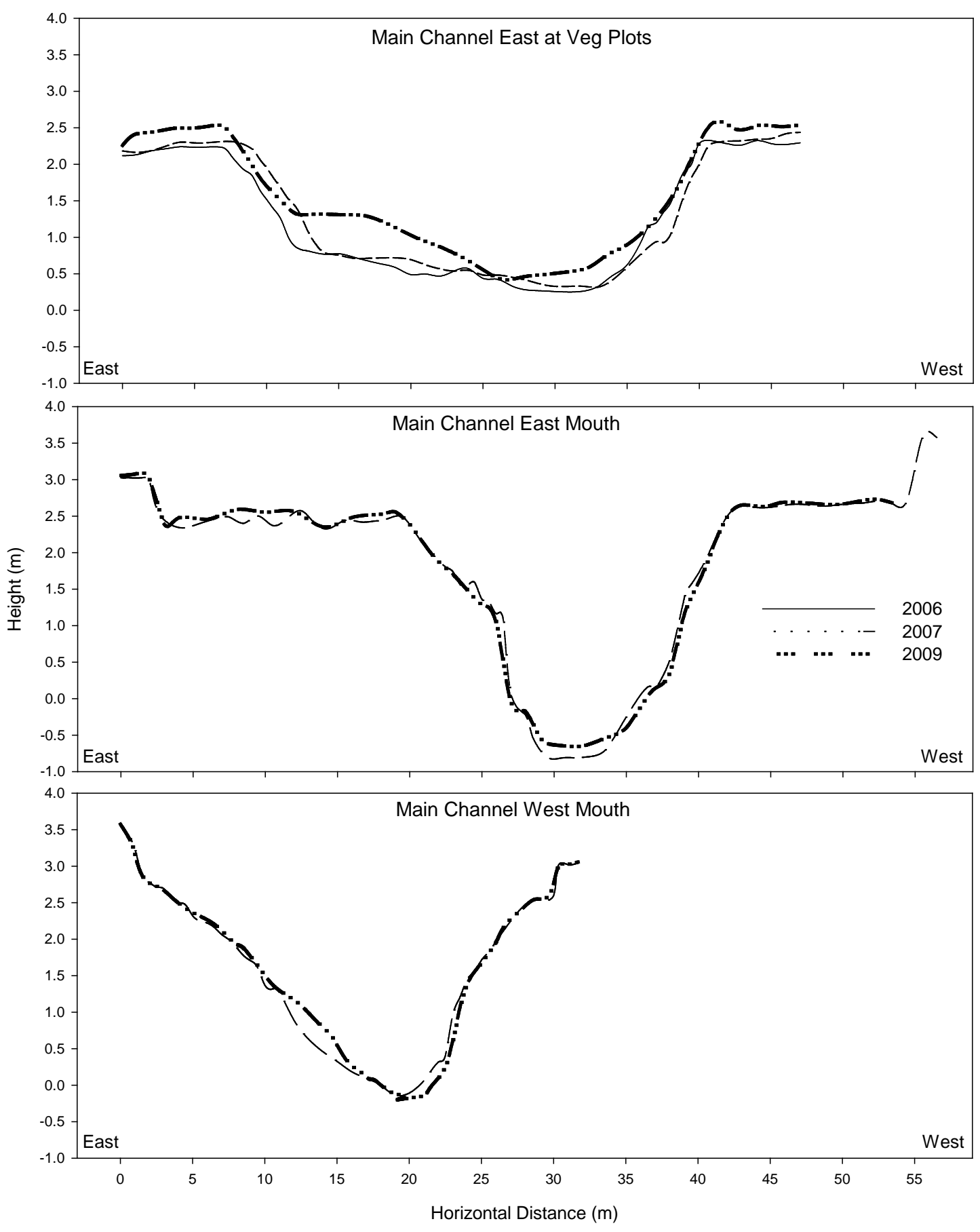

Figure 2.16. Channel Cross Sections at Crims Island Restoration Site for 1,2 and 4 Years after Restoration 

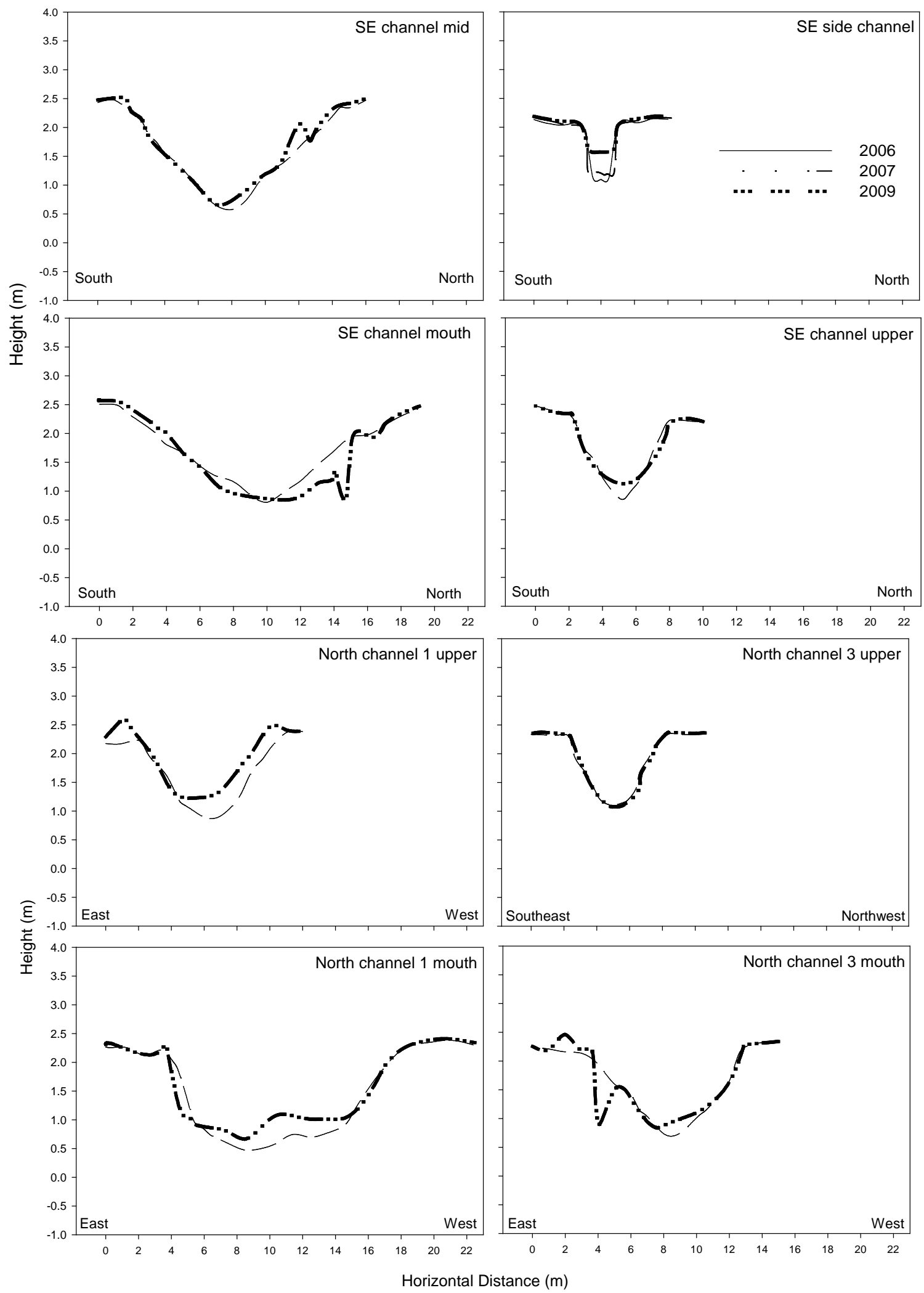

Figure 2.16. (contd) 
Although some trends are clear at each restoration and reference site, each channel cross section must to some degree be interpreted individually. For example, the Seal Slough location designated "above fork" (Figure 2.15) was just upstream of a large beaver dam in 2005, which was broken up and moved out by 2006, accounting for the incision that has occurred there to convey flows.

Like the dike breaches on the Grays River (Figure 2.13), the channels excavated at Crims Island were to some degree built to convey flows greater than they in fact do (Figure 2.16). Most channels at Crims Island are accreting, indicating that the flows they convey are insufficient to further incise or erode the channels.

\subsection{Material Exchange}

\section{Prepared by Dana Woodruff, Curtis Roegner, Ron Thom, Earl Dawley, April Silva, John Vavrinec, and Gary Johnson}

Among the key functions of tidal wetland systems is their ability to trap, process, and export various materials (Mitsch and Gosselink 2000). These materials include suspended sediments, organic matter, organisms, and nutrients. In this role, tidal wetlands contribute to the overall trophic conditions and productivity of the broader estuary, while supporting their own productivity and support for wetlandassociated wildlife. Diking and levee construction, with subsequent conversion of tidal wetlands into pastures and agricultural production, have removed approximately $70 \%$ of the tidal wetland area from the estuary (Thomas 1983). Loss of tidal wetlands is believed to have resulted in a significant loss of marsh macrodetritus input to the estuary (Simenstad et al. 1990). This loss coupled with the enhanced production of plankton in the reservoirs has resulted in a shift in the food web structure in the estuary from marsh-based to a plankton-based (Bottom et al. 2005; Maier and Simenstad 2009). It is generally thought that restoration of sources of macrodetritus and the processing of nutrients, trapping of sediments, and export of invertebrate fish prey can be achieved through restoration of tidal exchange and subsequent re-development of productive tidal wetland systems. So far this outcome has not been tested in the Columbia River, and there are minimal studies throughout the world that focus on exchange from restored tidal wetland systems.

One of the ways to understand the effects of restoration actions on tidal wetland systems is to measure the exchange of water and its associated constituents (e.g., macrodetritus, dissolved organic matter, nutrients, suspended sediments, invertebrate prey, and fish) in and out of a restored tidal wetland site. A comparison of exchange differences of these constituents before a site restoration and after a site restoration, or comparison to a reference site provides the most useful information regarding the effects of restoration actions. Our goal is to develop these types of data sets that can be used to predict the cumulative effect of multiple restoration actions on the flux of ecosystem-relevant materials from the restored sites to the estuary. To extrapolate results from our study sites to broader areas, we are developing and collecting data that relate straightforward metrics about aspects of the wetland (e.g., average daily wetted area) to the broader estuary through mass flux of materials to the estuary. Ultimately, we hope to answer the question "At what point do restoration actions for tidal wetlands have a detectable effect on the broader estuarine ecosystem?”

Our primary focus in this section is to report preliminary results from an intensive material-exchange study that was conducted during April 2009 spring and neap tides at the Kandoll restoration site in Grays 
River (Figure 1.2, previous section). This work is part of a larger body of exchange data that was collected between 2005 and 2008 at Vera Slough, the Julia Butler Hansen Refuge, and Kandoll Farm restoration sites, before and after tide-gate removal/replacement (Figure 1.2). Constituents that were measured during the April 2009 study included the following biogeochemical water properties: total organic carbon (TOC), total suspended solids (TSSs) including inorganic and organic fractions, chlorophyll a concentration, and nutrients $\left(\mathrm{NO}_{3}, \mathrm{NO}_{2}, \mathrm{NH}_{4}+, \mathrm{PO}_{4}, \mathrm{SiO}_{4}\right)$. In addition, neuston-net samples were collected for macrodetritus and fish, and fish trap-net samples were collected. Flux estimates and nutrient data are still being analyzed.

\subsubsection{Methods}

Water property, neuston-net, and fish-trap samples were collected during a spring tidal cycle from April 8 through 10, 2009. Samples were collected during two semidiurnal tidal periods (four ebb and four flood tides) over an approximate 48-hr time period. Similar samples were collected during a neap tidal cycle between April 15 and 16, covering a single semidiurnal period.

\subsubsection{Water-Property Sampling}

We collected surface-water samples (to $\sim 0.2 \mathrm{~m}$ ) approximately every 1 to 2 hours at the Kandoll replacement culvert. Subsamples were taken for various dissolved and particulate constituents. Water $(50 \mathrm{~mL})$ was syringe-filtered onsite through a Whatman GF/C filter for later chlorophyll- $a$ analysis and stored on ice in the dark. Samples were analyzed by following standard protocols (Parsons et al. 1984). Unfiltered water $(20 \mathrm{~mL})$ was collected in acid-cleaned vials for TOC analysis. Water $(60 \mathrm{~mL})$ was syringe-filtered through a Surfactant-Free Cellulose Acetate filter for nutrient analysis. All samples were stored frozen until analysis. Approximately $1 \mathrm{~L}$ of water was collected for total, organic, and inorganic suspended sediment analysis and kept refrigerated until samples were filtered within several days of collection. Samples were analyzed using Standard Methods 2540 C and E (APHA 1998) protocols.

\subsubsection{Neuston-Net Sampling}

Fish, insects, and macrodetritus moving through the culvert were collected with a Manta-style neuston-net $(1.5 \times 0.5 \mathrm{~m}$ mouth dimensions, 300- $\mu \mathrm{m}$ mesh net). The net was deployed to passively fish the ambient current into and out of the culvert. Two or three casts per ebb or flood tide were made, depending on current velocity. The volume of water filtered through the net was measured with a General Oceanics flowmeter and was used to compute the concentration of material (\# ind. $/ \mathrm{m}^{3}$ for fish and insects, $\mathrm{g} / \mathrm{m}^{3}$ for macrodetritus). The instantaneous flux (\# ind. $/ \mathrm{m}^{2} / \mathrm{s}$ or $\mathrm{g} / \mathrm{m}^{2} / \mathrm{s}$ ) will be computed as $\mathrm{C} * \mathrm{U}$, where $\mathrm{U}$ is the horizontal velocity $(\mathrm{m} / \mathrm{s})$. Flux is integrated over each tide to estimate total tidal transport of material. Exchange and transport measurements in this study are shown as positive in the landward direction (import) and negative in the river direction (export). The fish and macrodetritus concentration results are reported here. The insect data are currently being analyzed, and will be reported in the 2010 synthesis report. Exchange and transport results will be reported in 2010 as well.

\subsubsection{Fish-Trap Sampling}

Habitat use by fish at the Kandoll restoration site was measured by deploying trap nets in the developing intertidal channels. The trap nets were composed of two net leads connected to a net throat and live box. Traps were set at high water and fished for 4 to 5 hours during the outgoing (ebb) tide to 
catch fish moving toward the river as water within the restoration site drained, and thus measured fish that entered the channel during the previous flood-tide period. During the intensive material-exchange study, we simultaneously fished three tidal channels. The first two trap nets (TN1 and TN2) fished tidal channels that continued a monitoring study initiated in 2007 (Johnson and Diefenderfer 2008, 2009). The third channel (TN3) was added during this study. The purpose of the three nets was to ascertain spatial heterogeneity of habitat use by fish. During the spring-tide sampling period, we fished two semidiurnal tidal periods (four ebb tides), which included two predominately day and two predominately night floodtide periods. During the subsequent neap tide, we fished a single semidiurnal period (one day, one night).

All captured fish were identified by species, enumerated, and measured to the nearest millimeter (fork length). Salmonids were anesthetized with a $50-\mathrm{mg} / \mathrm{L}$ solution of MS-222 before measurement. When catches were large, a subset of 100 fish was measured. We closely examined all salmon for adipose-fin clips or other external marks indicating hatchery origin. Fish were allowed to recover before being released downstream of the net.

\subsubsection{Calculation of Exchange and Net Transport}

The general approach and equations for calculation of mass flux and total and net transport of material imported to and exported from the restoration sites is described by Thom et al. (2008). The instantaneous measurements described above were augmented with several additional data sources. A time series of water level and temperature data was collected inside the culvert with an underwater pressure/temperature sensor (HOBO model U20, Onset Corporation). HOBO temperature/light sensors were also deployed near the trap nets in each tidal channel. From these sensor data, time series of mean daily temperature and hourly light intensity data were plotted.

\subsubsection{Results and Discussion}

To date, the instantaneous concentration data for TSSs and inorganic and organic fractions, fish and macrodetritus neuston-net sampling, and fish trap-net sampling have been analyzed and are reported in this data summary. The insect, nutrient, and TOC data are still being analyzed. Additional data are being processed or will be modeled to finalize calculations of the instantaneous mass flux (F), instantaneous mass transport (Q), total mass transport, and volume exchange and transport.

\subsubsection{Total, Inorganic, and Organic Suspended Sediments}

Instantaneous TSS concentration ranged from $4.1 \mathrm{mg} / \mathrm{L}$ to $17.0 \mathrm{mg} / \mathrm{L}$ during the spring tidal cycle (Figure 2.17). During the neap tidal cycle, TSS ranged from $4.1 \mathrm{mg} / \mathrm{L}$ to $13.1 \mathrm{mg} / \mathrm{L}$ (Figure 2.18). The average concentration of TSSs was slightly higher during the spring tides (mean $8.96 \pm 3.40 \mathrm{mg} / \mathrm{L}$ ) (Figure 2.19) than during the neap tides (mean $6.19 \pm 1.91 \mathrm{mg} / \mathrm{L}$ ) (Figure 2.20). This may be correlated with higher flow velocities, but additional analysis is needed to make this comparison. During both the spring and neap tidal cycles, inorganic suspended sediments dominated the TSS fraction concentration; however, there was a slightly higher percentage of organic matter present during the neap tidal series (26\%) compared to the spring-tide series (21\%). The concentration of organic matter during the neap-ebb tides was $32 \%$ compared to $23 \%$ during the neap flood tides, indicating a possible export of organic matter, but volume-exchange calculations are needed to make that determination. 


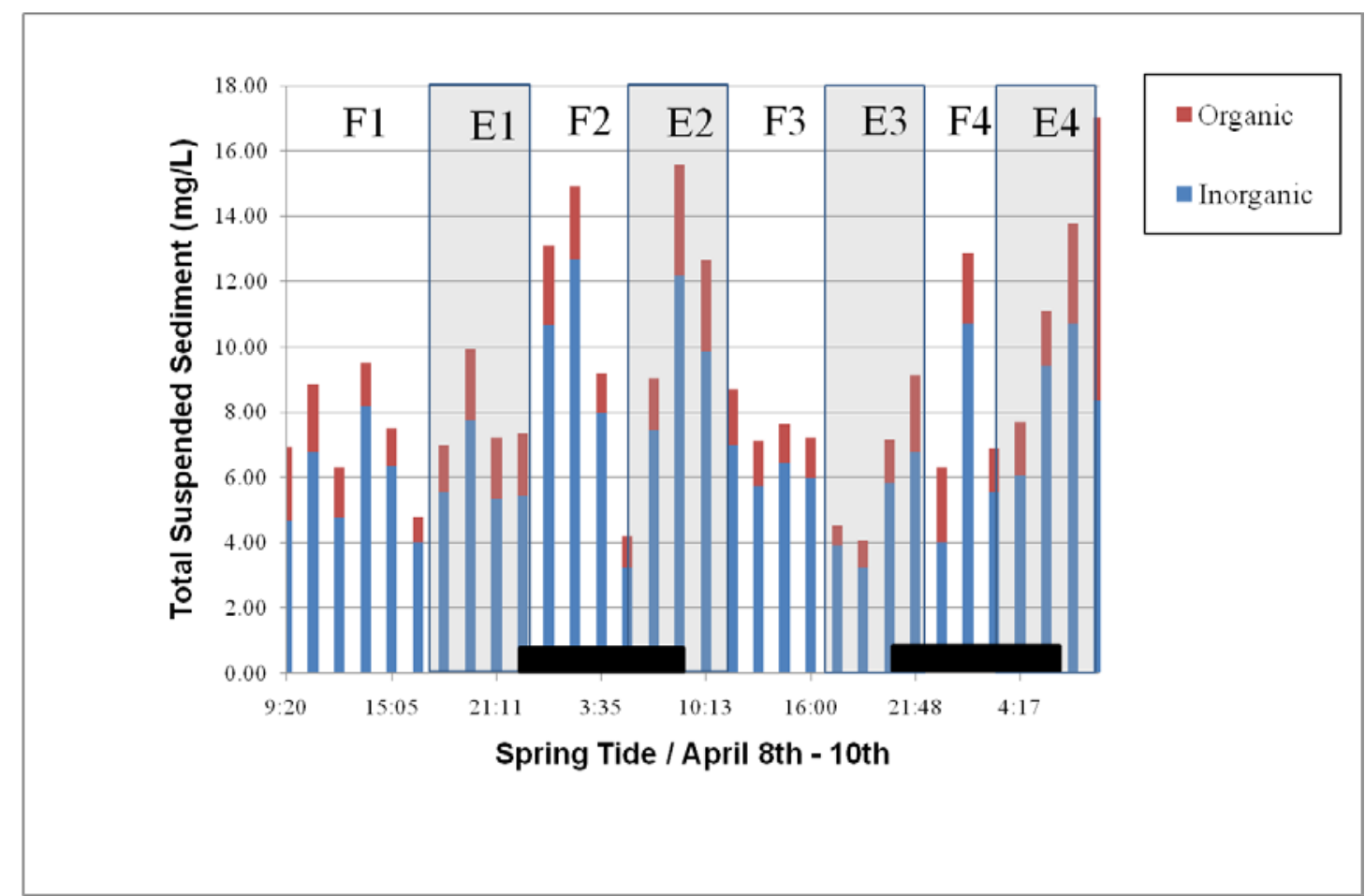

Figure 2.17. Total, Inorganic, and Organic Suspended Sediment Concentration: Kandoll Farm through Time during a Spring Tide. E denotes ebb tide and F denotes flood tide.

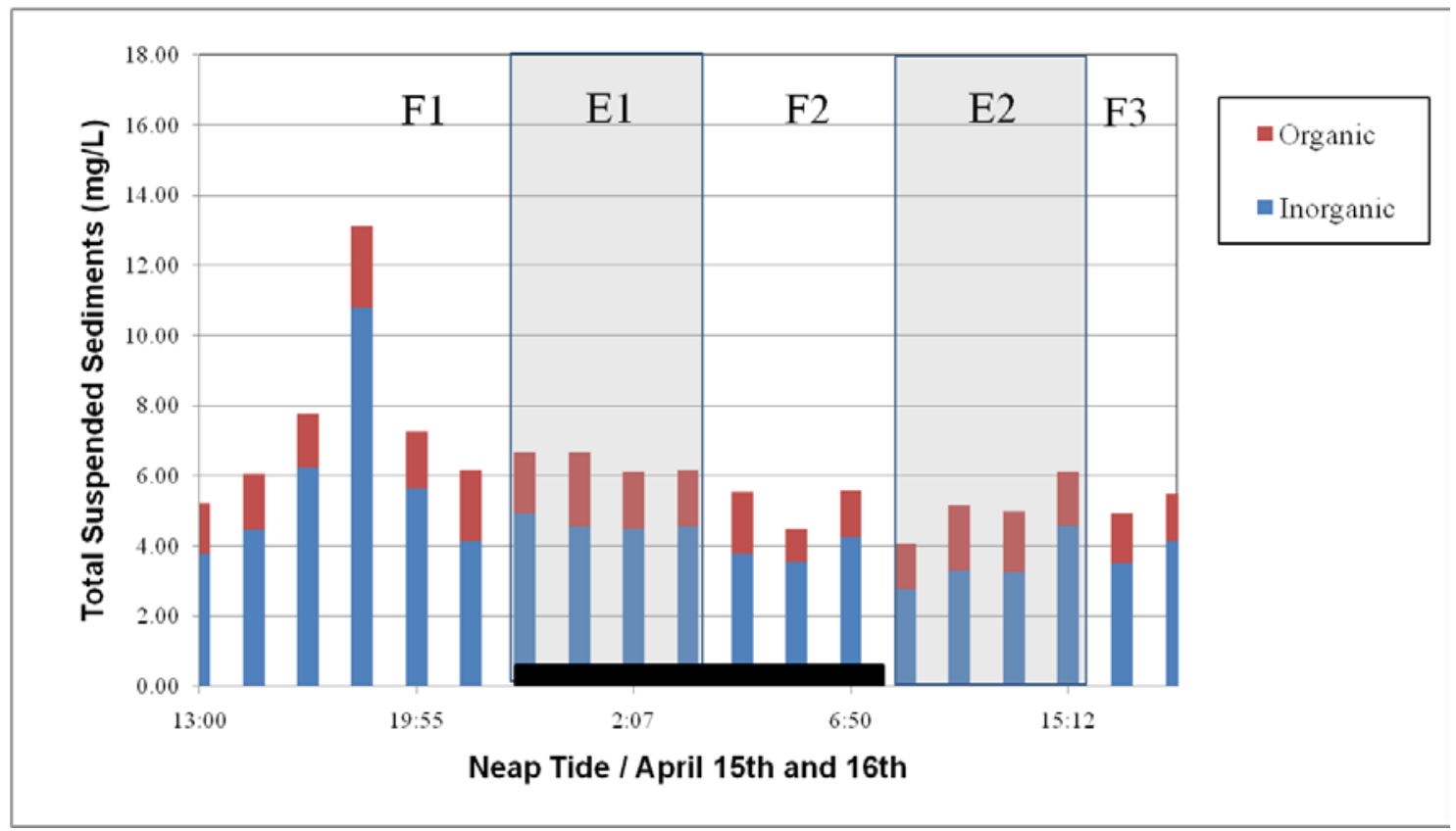

Figure 2.18. Total, Inorganic, and Organic Suspended Sediment Concentration: Kandoll Farm through Time during a Neap Tide. E denotes ebb tide and F denotes flood tide. 


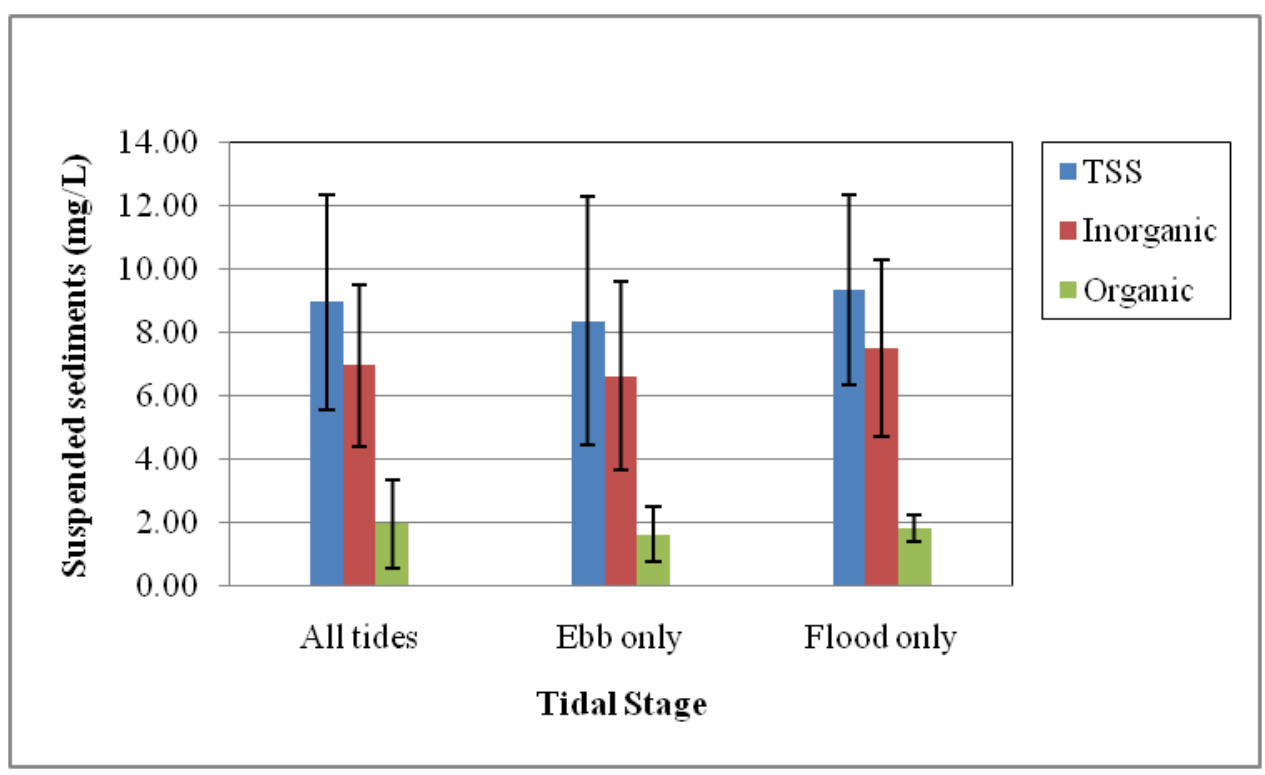

Figure 2.19. Average Concentration ( \pm s.d.) of Total, Inorganic, and Organic Suspended Sediments During Various Tidal Stages of a Spring-Tide Series at Kandoll Farm

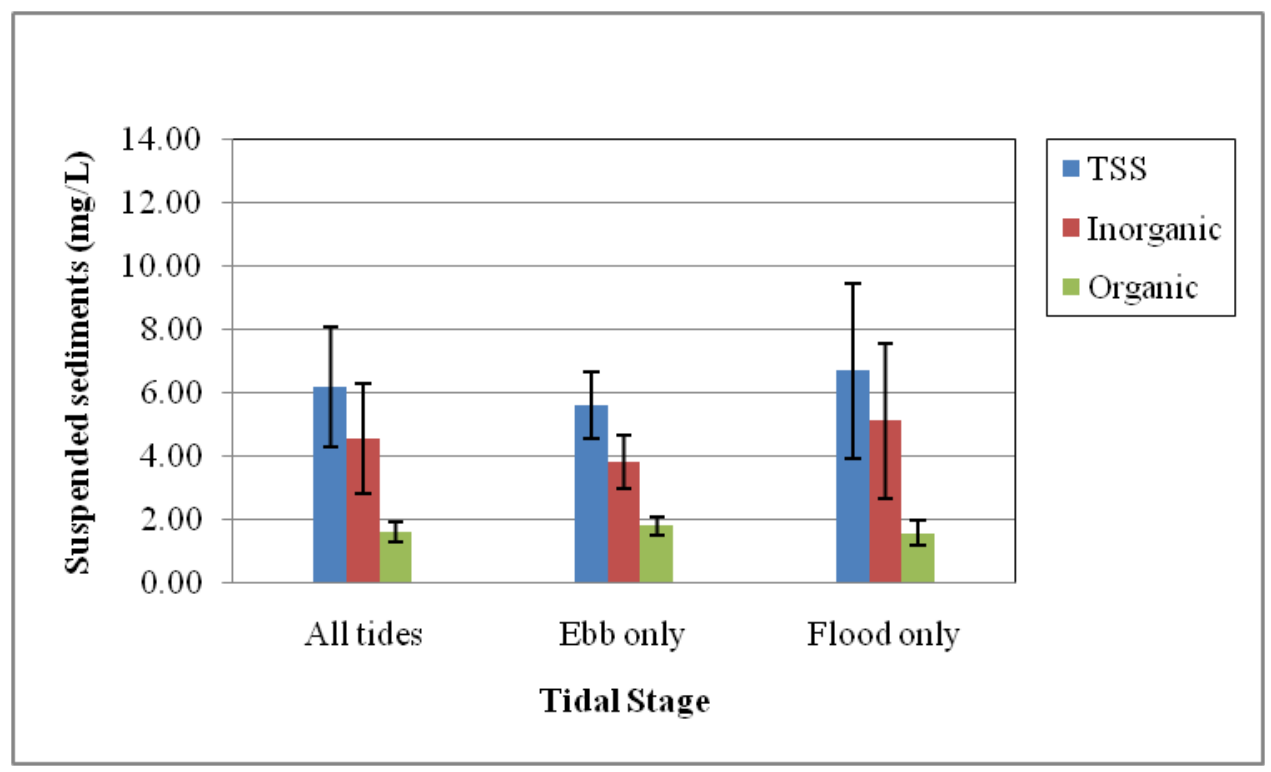

Figure 2.20. Average Concentration ( \pm s.d.) of Total, Inorganic, and Organic Suspended Sediments During Various Tidal Stages of a Neap-Tide Series at Kandoll Farm

\subsubsection{Neuston}

The instantaneous concentration of fish collected with the neuston-net during the spring tidal cycle sample period is shown in Figure 2.21. Low horizontal velocities limited sampling capability during the neap tidal cycle, so concentrations could not be accurately determined then. Stickleback and chum salmon were collected during both ebb and flood tides. Maximum concentrations occurred during flood tide and were 2.8 individuals $/ \mathrm{m}^{3}$ for stickleback and 1.0 individuals/ $\mathrm{m}^{3}$ for chum. The mean size of each species was similar across sample times. These preliminary data indicate that small fish were routinely transiting through the culvert (Figure 2.21). 

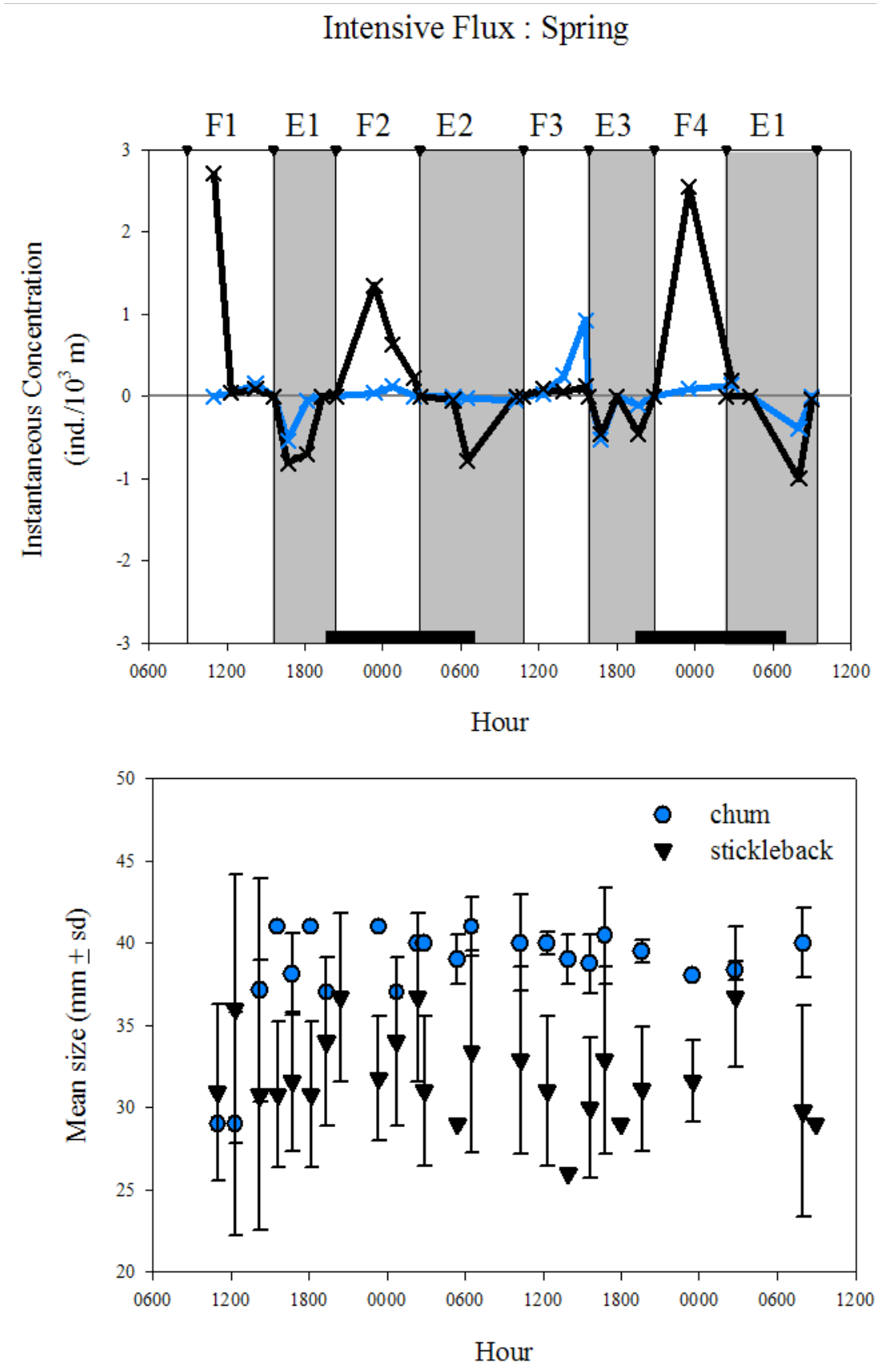

Figure 2.21. Instantaneous Concentration of Stickleback (black) and Chum Salmon (blue) During the Spring Sampling Period (upper plot). Negative concentrations denote ebb periods (gray bands). Black bars indicate periods of darkness. The mean size ( \pm s.d.) of stickleback (black) and chum salmon (blue) and shown in the lower plot.

Macrodetritus concentration exhibited regular peaks corresponding to the periods of (presumed) maximum velocity (Figure 2.22). The highest concentration of macrodetritus ( $\left.90 \mathrm{~g} / \mathrm{m}^{3}\right)$ occurred during a large ebb tide; otherwise maximum concentrations were of similar magnitude during flood and ebb periods (20 to $30 \mathrm{~g} / \mathrm{m}^{3}$ ). 


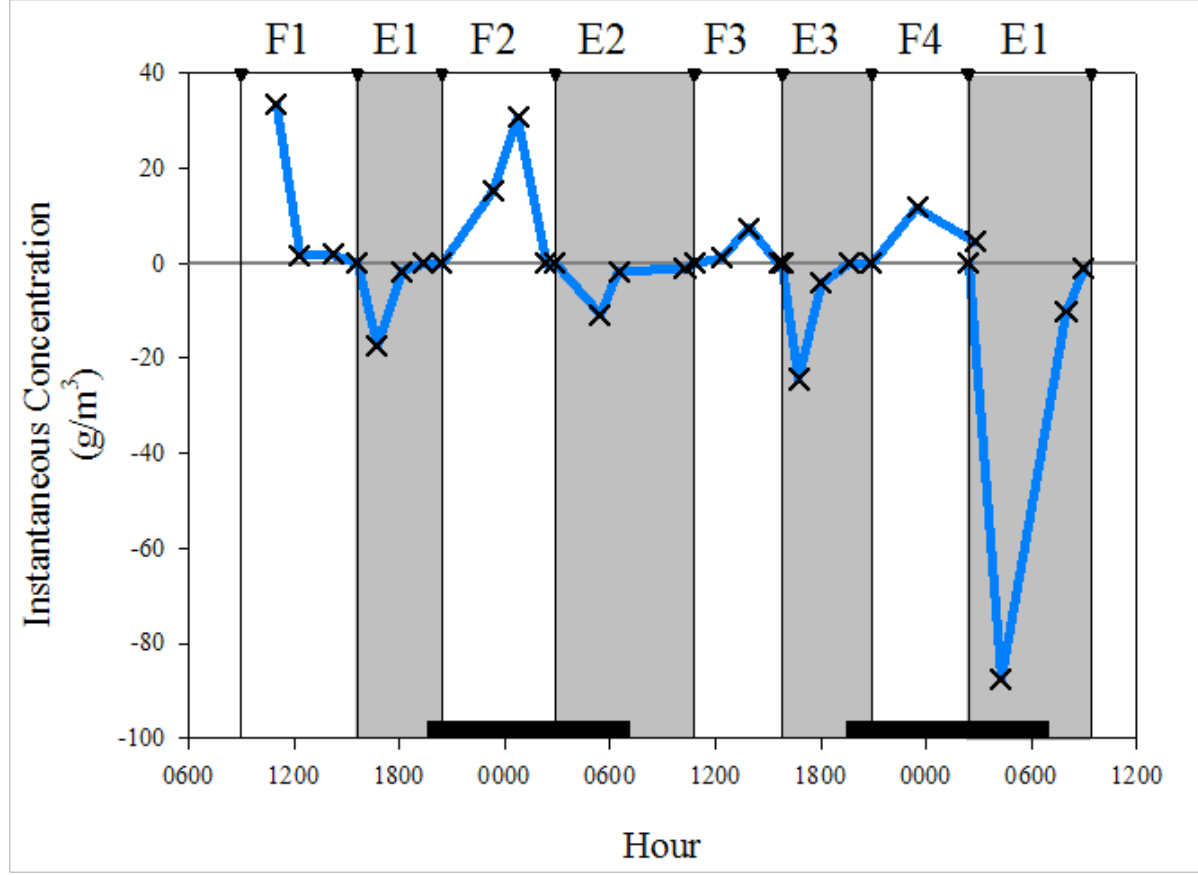

Figure 2.22. Instantaneous Concentration of Macrodetritus During the Spring-Tide Sampling Period. Negative concentrations denote ebb periods (gray bands where material is moving out). Black bars indicate periods of darkness.

\subsubsection{Fish}

Fish species sampled during the trap-net deployments are shown in Table 2.5. Ten species including three salmonids were collected, although only chum salmon and stickleback were abundant.

Table 2.5. List of Fish Species Observed During the Intensive Material-Exchange Study

\begin{tabular}{lll}
\hline Code & Species Common Name & \multicolumn{1}{c}{ Species } \\
\hline Stick & Threespine stickleback & Gasterosteus aculeatus \\
Chin & Chinook salmon & Oncorhynchus tshawytscha \\
Chum & Chum salmon & Oncorhynchus keta \\
Kill & Banded killifish & Fundulus diaphanus \\
Coho & Coho salmon & Oncorhynchus kisutch \\
Suck & Largescale sucker & Catostomus macrocheilus \\
Cott & Prickly sculpin & Cottus asper \\
Peam & Peamouth & Mylocheilus caurinus \\
Lamp & River lamprey & Lampetra ayresi \\
Dace & Dace & Unidentified \\
\hline
\end{tabular}

During the spring-tide series sampling, chum abundance greatly exceeded all previous observations in the Grays River system, and we likely sampled the peak of the migration period. Comparison of chum catches between the three trap nets suggests that the higher catches generally followed a nocturnal flood tide (i.e., movement into the marsh at night), while stickleback abundance was more uniform over time 
(Figure 2.23). Note that absolute abundances between tidal channels cannot be reliably compared without standardization by channel area. Observations during the neap sampling were confined to two tides (Table 2.6, Figure 2.23), and chum salmon abundance was both greatly reduced overall and also limited to TN2, indicating spatial differences in habitat use during neap periods (Figure 2.23).

Table 2.6. Abundance of Fish Captured at Trap-Net (TN) Sites During the Spring and Neap Periods of the Intensive Material-Exchange Study. Species codes are defined in Table 2.5.

\begin{tabular}{ccccccccccccc}
\hline \multirow{2}{*}{$\begin{array}{c}\text { Tide } \\
\text { Cycle }\end{array}$} & Net & Number & \multicolumn{10}{c}{ Species Code } \\
\cline { 3 - 14 } & of Tides & Chin & Coho & Chum & Stick & Kill & Cott & Peam & Suck & Dace & Lamp \\
\hline \multirow{5}{*}{ Spring } & TN1 & 4 & 0 & 1 & 1657 & 1795 & 3 & 0 & 1 & 1 & 0 & 2 \\
& TN2 & 4 & 1 & 10 & 1035 & 1153 & 1 & 0 & 0 & 0 & 0 & 0 \\
& TN3 & 3 & 2 & 0 & 2480 & 952 & 0 & 0 & 0 & 1 & 1 & 0 \\
& Total & 11 & 3 & 11 & 5172 & 3900 & 4 & 0 & 1 & 2 & 1 & 2 \\
\hline \multirow{5}{*}{ Neap } & TN1 & 2 & 3 & 1 & 3 & 209 & 0 & 2 & 0 & 0 & 0 & 0 \\
& TN2 & 2 & 4 & 11 & 250 & 2436 & 0 & 20 & 0 & 0 & 0 & 0 \\
& TN3 & 2 & 0 & 9 & 2 & 1047 & 0 & 3 & 0 & 0 & 0 & 0 \\
& Total & 6 & 7 & 21 & 255 & 3692 & 0 & 25 & 0 & 0 & 0 & 0 \\
\hline
\end{tabular}
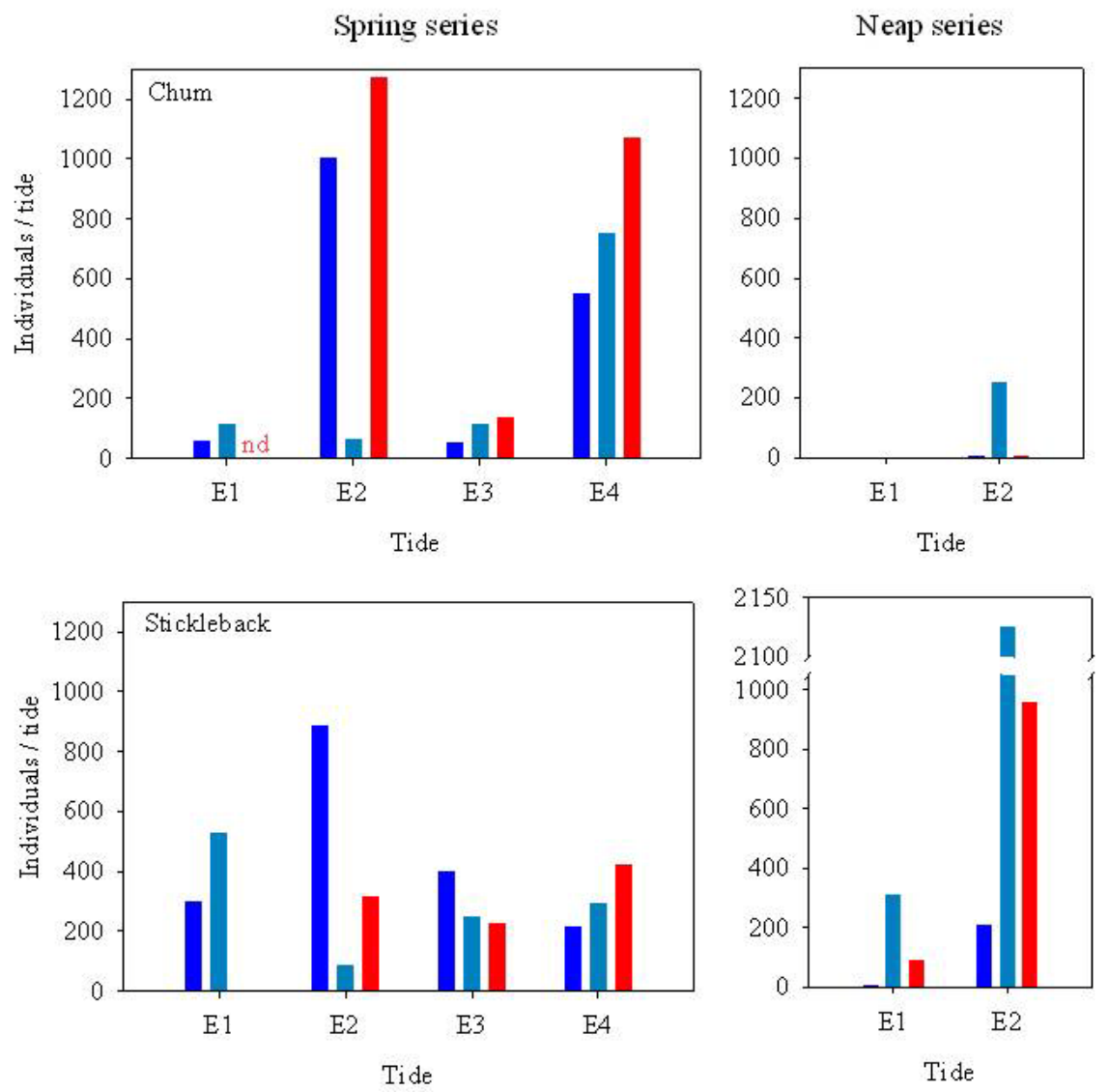

Figure 2.23. Abundance of Chum Salmon (upper plots) and Stickleback (lower plots) at Trap-Net Sites (colored bars) During Spring (left) and Neap (right) Sampling Periods. The abscissa code designates ebb-tide number. 
The time series of mean daily temperature exhibit few differences among trap-net sites or between sample periods (Figure 2.24 upper plot). Temperatures were well below critical values (grey band, Figure 2.24). However, light intensity differed among sites and sample times (Figure 2.24 lower plot). TN3 experienced lower intensities than the other sites, which may have been due to sensor orientation, and the spring tidal period was darker than the neap tidal period. It is unknown whether brighter daylight periods affected the lower catch rates during the neap tidal series.
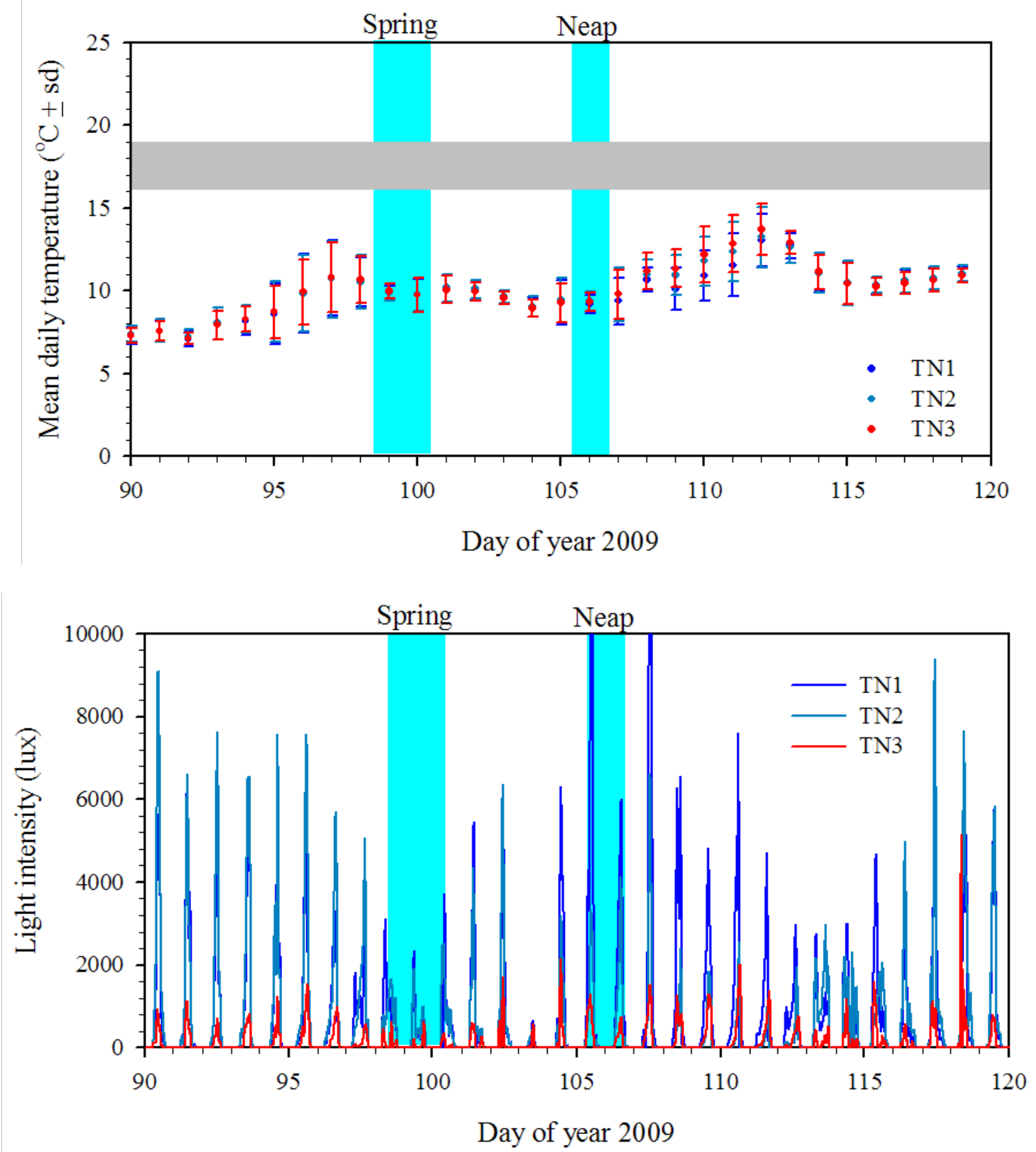

Figure 2.24. Time Series of Mean Daily Temperature (upper plot) and Light Intensity (lower plot). Measured in trap nets in the days surrounding the neap-tide sampling periods (turquoise band). 



\title{
3.0 Action Effectiveness Meta-Analysis
}

\author{
Prepared by Gary Johnson, April Cameron, Catherine Corbett, and Ron Thom
}

\subsection{Introduction}

Compiling, merging, and analyzing data derived from monitoring the effectiveness of various restoration projects (hereafter called effectiveness monitoring ${ }^{1}$ ) is fundamental to the evaluation of success or failure of ecosystem restoration. The challenge is to integrate multiple site-scale monitoring results to make inferences at an estuary-wide scale. Pre- and post-restoration monitoring data have been collected at restoration and associated reference sites in the LCRE. These data were used in a descriptive, non-statistical meta-analysis to gauge the success to date of tidal reconnection restoration. Lessons learned in the meta-analysis process are described in this section. The methods and results from this analysis will help inform decision-makers in the Federal LCRE Habitat Restoration Program. The objective was to perform a meta-analysis of effectiveness data from tidal reconnection restoration projects in the LCRE to determine the proportion of projects that were successful ${ }^{2}$. This meta-analysis builds on the one conducted by Johnson et al. (2009).

\subsection{Methods}

The method for the meta-analysis was to 1 ) review literature and contact monitoring practitioners, 2) identify and select study sites, 3) determine response variables, and 4) compile data. The response variables of interest were water temperature, sediment accretion rate, and juvenile salmon presence. We also compared photo points before and after the restoration action at several sites. The effectiveness data were collected using the protocols developed by Roegner et al. (2009a). This particular meta-analysis is descriptive, not statistical.

\subsubsection{Project Sites}

Eighteen projects were considered for inclusion in the meta-analysis of effectiveness monitoring data (Table 3.1). The 18 projects were identified from knowledge by the authors of various tidal reconnection actions in the LCRE. The list covers a wide range of projects, although it is not exhaustive. The project sites were located from Columbia river kilometer (rkm) 18 to rkm 227. Restoration project implementation ranged from 1995 to present and was performed by multiple entities. Restoration actions included dike breaches, culvert replacements, and riparian improvements.

Projects were selected for the meta-analysis if they had sufficient pre- and post-restoration effectiveness monitoring data, were proximal to the main stem Columbia River or a major tributary in tidal waters, and involved tidal reconnection. Based on these criteria, seven projects were selected for the meta-analysis: Crims Island, Fort Clatsop, Johnson Property, Kandoll Farm, Lewis and Clark, Mirror Lake, and Vera Slough. The monitoring data available for these projects are listed in Table 3.2.

\footnotetext{
${ }^{1}$ Effectiveness monitoring specifically pertains to monitoring at restoration and reference sites for the purpose of evaluating the effects of the restoration action.

${ }^{2}$ By definition, success is when the response variable(s) trend in the desired direction when compared between preversus post-restoration conditions or between restoration versus reference site conditions.
} 
Table 3.1. Descriptive Data about Restoration Sites. Shading indicates sites used in the preliminary meta-analysis.

\begin{tabular}{|c|c|c|c|c|c|}
\hline Site & $\begin{array}{l}\text { Col. River } \\
\text { Kilometer }\end{array}$ & Year & Implementers & Restoration Type & Comment \\
\hline Big Creek & 68 & 2006 & NCWA/CREST & $\begin{array}{l}\text { Creek re-direction around a } \\
\text { man-made velocity barrier }\end{array}$ & Intensively monitored \\
\hline Crims Island & 88 & 2005 & USGS/PNNL & Dike breach and excavation & Intensively monitored \\
\hline Ft. Clatsop & $\begin{array}{l}24 \text { (Lewis \& } \\
\text { Clark River) }\end{array}$ & 2007 & EP/CREST & Culvert replacement & Ibid. \\
\hline Ft. Columbia & 21 & 2010 & EP/CREST & Culvert replacement & $\begin{array}{l}\text { Pre-restoration data } \\
\text { collection }\end{array}$ \\
\hline Haven Island & $\begin{array}{l}15 \text { (Youngs } \\
\text { River) }\end{array}$ & 2011 & CLT/CREST & Dike breaches & $\begin{array}{l}\text { Pre-restoration data } \\
\text { collection }\end{array}$ \\
\hline $\begin{array}{l}\text { Johnson } \\
\text { Property }\end{array}$ & $\begin{array}{l}35 \text { (Grays } \\
\text { River) }\end{array}$ & 2004 & CLT/CREST/ UW & Dike breach & $\begin{array}{l}1 \text { year pre-restoration and } \\
3 \text { years post; completed }\end{array}$ \\
\hline $\begin{array}{l}\text { Julia Butler } \\
\text { Hanson }\end{array}$ & 55 & 2009 & USFWS/PNNL/NMFS & Tide-gate replacement & $\begin{array}{l}\text { Further construction } \\
2010\end{array}$ \\
\hline $\begin{array}{l}\text { Kandoll } \\
\text { Farm }\end{array}$ & $\begin{array}{l}36 \text { (Grays } \\
\text { River) }\end{array}$ & 2005 & PNNL/NMFS/CREST & Culvert replacement & Intensively monitored \\
\hline $\begin{array}{l}\text { Lewis and } \\
\text { Clark }\end{array}$ & $\begin{array}{l}26 \text { (Lewis \& } \\
\text { Clark River) }\end{array}$ & 2006 & NFWF/CREST & Dike breaches & $\begin{array}{l}\text { Intensively monitored; } \\
\text { pre and post- monitoring; } \\
\text { completed }\end{array}$ \\
\hline $\begin{array}{l}\text { Megler } \\
\text { Creek }\end{array}$ & 23 & 2010 & EP/CREST & Culvert replacement & $\begin{array}{l}\text { Pre-restoration data } \\
\text { collection }\end{array}$ \\
\hline Mirror Lake & 205 & 2007 & EP/NMFS/ Parametrix & $\begin{array}{l}\text { Culvert, stream, and } \\
\text { riparian habitat } \\
\text { improvements }\end{array}$ & $\begin{array}{l}\text { Intensively monitored but } \\
\text { not a tidal reconnection }\end{array}$ \\
\hline Otter Point & $\begin{array}{l}25 \text { (Lewis } \\
\text { \&Clark } \\
\text { River.) }\end{array}$ & 2010 & $\begin{array}{l}\mathrm{EP} / \mathrm{BPA} / \mathrm{NCWA} / \\
\mathrm{CREST}\end{array}$ & Dike breach & $\begin{array}{l}\text { Pre-restoration data } \\
\text { collection; construction } \\
2010\end{array}$ \\
\hline $\begin{array}{l}\text { Perkins } \\
\text { Creek }\end{array}$ & $\begin{array}{l}14 \text { (Skipanon } \\
\text { River) }\end{array}$ & 2009 & NCWA/CREST & Culvert replacement & $\begin{array}{l}\text { No post-restoration } \\
\text { monitoring }\end{array}$ \\
\hline $\begin{array}{l}\text { Sandy River } \\
\text { Delta }\end{array}$ & 123 & $\begin{array}{l}\text { 2004- } \\
\text { present }\end{array}$ & EP/ACFM/BPA/USFS & $\begin{array}{l}\text { Invasives removal and } \\
\text { plantings }\end{array}$ & $\begin{array}{l}\text { No baseline; Post } \\
\text { restoration monitoring } \\
\text { since } 2008\end{array}$ \\
\hline $\begin{array}{l}\text { Scappoose } \\
\text { Bottoms }\end{array}$ & 142 & $\begin{array}{l}2005, \\
2007 \text { to } \\
\text { present }\end{array}$ & EP/SBWC/CREST & $\begin{array}{l}\text { Riparian improvements } \\
(2007+) \text { and cattle } \\
\text { exclusion (2005) }\end{array}$ & $\begin{array}{l}\text { No pre-restoration } \\
\text { monitoring for fish }\end{array}$ \\
\hline $\begin{array}{l}\text { Skipanon } \\
\text { River } \\
\text { Floodplain }\end{array}$ & $\begin{array}{l}14 \text { (Skipanon } \\
\text { River) }\end{array}$ & 2008 & NCWA/CREST & $\begin{array}{l}\text { Alcove excavation and } \\
\text { riparian planting }\end{array}$ & No pre-restoration data \\
\hline Trestle Bay & 11 & 1995 & $\begin{array}{l}\text { PNNL/NMFS/ } \\
\text { CREST/EP }\end{array}$ & Dike breach & No pre-restoration data \\
\hline $\begin{array}{l}\text { Vera } \\
\text { Slough }\end{array}$ & 19 & 2005 & $\begin{array}{l}\text { PNNL/NMFS/ } \\
\text { CREST }\end{array}$ & Tide-gate replacement & Intensively monitored \\
\hline $\begin{array}{l}\text { Waluski } \\
\text { River }\end{array}$ & & 2010 & CLT/CREST & Dike Breaches & No pre-restoration data \\
\hline $\begin{array}{l}\text { Willow } \\
\text { Grove }\end{array}$ & 104 & 2011 & CLT/CREST & Habitat enhancement & $\begin{array}{l}\text { Pre-restoration } \\
\text { monitoring postponed }\end{array}$ \\
\hline \multicolumn{6}{|c|}{$\begin{array}{l}\text { ACFM = Ash Creek Forest Management; BPA = Bonneville Power Administration; CLT = Columbia Land Trust; } \\
\text { CREST = Columbia River Estuary Study Taskforce; EP = Estuary Partnership; NCWA = North Coast Watershed } \\
\text { Association NMFS = National Marine Fisheries Service; PNNL = Pacific Northwest National Laboratory; SBWC = } \\
\text { Scappoose Bay Watershed Council; UW = University of Washington }\end{array}$} \\
\hline
\end{tabular}


Table 3.2. Data Availability ( $\mathrm{Y}=$ yes; $\mathrm{N}=$ no) at the Seven Sites Selected for Meta-Analysis

\begin{tabular}{|c|c|c|c|c|c|c|c|c|c|}
\hline & & $\begin{array}{l}\text { Photo } \\
\text { Point }{ }^{(a)}\end{array}$ & $\begin{array}{l}\text { Water } \\
\text { Depth }\end{array}$ & $\begin{array}{c}\text { Water } \\
\text { Temp. }{ }^{(a)}\end{array}$ & $\begin{array}{c}\text { Sediment } \\
\text { Accretion }^{(\mathrm{a})}\end{array}$ & $\begin{array}{l}\text { Vegetation } \\
\text { Similarity }\end{array}$ & $\begin{array}{c}\text { Fish } \\
\text { Presence }^{(a)}\end{array}$ & $\begin{array}{l}\text { Fish } \\
\text { Diet }\end{array}$ & $\begin{array}{l}\text { Biomass } \\
\text { Flux } \\
\end{array}$ \\
\hline \multirow[t]{3}{*}{ Crims Is. } & Pre & $\mathrm{Y}$ & $\mathrm{N}$ & $\mathrm{N}$ & NA & $\mathrm{N}$ & $\mathrm{Y}$ & $\mathrm{N}$ & $\mathrm{N}$ \\
\hline & Post & Y & $\mathrm{N}$ & $\mathrm{N}$ & $\mathrm{Y}$ & $?$ & Y & Y & $\mathrm{N}$ \\
\hline & Ref & Y & $\mathrm{N}$ & $\mathrm{N}$ & $\mathrm{Y}$ & $\mathrm{Y}$ & Y & $\mathrm{N}$ & $\mathrm{N}$ \\
\hline \multirow{3}{*}{$\begin{array}{l}\text { Ft. } \\
\text { Clatsop }\end{array}$} & Pre & $\mathrm{N}$ & $\mathrm{Y}$ & $\mathrm{Y}$ & NA & $\mathrm{N}$ & $\mathrm{Y}$ & $\mathrm{N}$ & $\mathrm{N}$ \\
\hline & Post & $\mathrm{Y}$ & $\mathrm{Y}$ & $\mathrm{Y}$ & $\mathrm{Y}$ & $\mathrm{N}$ & $\mathrm{Y}$ & $\mathrm{Y}$ & $\mathrm{N}$ \\
\hline & Ref & Y & Y & Y & $\mathrm{Y}$ & $\mathrm{N}$ & Y & Y & $\mathrm{N}$ \\
\hline \multirow{3}{*}{$\begin{array}{l}\text { Johnson } \\
\text { Property }\end{array}$} & Pre & $\mathrm{N}$ & $\mathrm{N}$ & $\mathrm{N}$ & NA & $\mathrm{N}$ & $\mathrm{N}$ & $\mathrm{N}$ & $\mathrm{N}$ \\
\hline & Post & Y & Y & Y & Y & $\mathrm{N}$ & Y & $\mathrm{Y}$ & $\mathrm{N}$ \\
\hline & Ref & Y & $\mathrm{Y}$ & Y & $\mathrm{N}$ & $\mathrm{N}$ & Y & Y & $\mathrm{N}$ \\
\hline \multirow{3}{*}{$\begin{array}{l}\text { Kandoll } \\
\text { Farm }\end{array}$} & Pre & Y & $\mathrm{Y}$ & $\mathrm{Y}$ & NA & $\mathrm{Y}$ & Y & $\mathrm{N}$ & $\mathrm{N}$ \\
\hline & Post & Y & $\mathrm{Y}$ & $\mathrm{Y}$ & Y & Y & Y & Y & $\mathrm{Y}$ \\
\hline & Ref & Y & $\mathrm{Y}$ & $\mathrm{N}$ & $\mathrm{Y}$ & $\mathrm{N}$ & $\mathrm{N}$ & $\mathrm{N}$ & Y \\
\hline \multirow{3}{*}{$\begin{array}{l}\text { Lewis \& } \\
\text { Clark }\end{array}$} & Pre & Y & $\mathrm{Y}$ & Y & NA & Y & Y & $\mathrm{Y}$ & $\mathrm{N}$ \\
\hline & Post & Y & Y & Y & $\mathrm{N}$ & Y & Y & Y & $\mathrm{N}$ \\
\hline & Ref & Y & $\mathrm{N}$ & $\mathrm{N}$ & $\mathrm{N}$ & Y & $\mathrm{N}$ & $\mathrm{N}$ & $\mathrm{N}$ \\
\hline \multirow{3}{*}{$\begin{array}{l}\text { Mirror } \\
\text { Lake }\end{array}$} & Pre & Y & $\mathrm{Y}$ & $\mathrm{Y}$ & NA & $\mathrm{N}$ & $\mathrm{N}$ & $\mathrm{N}$ & $\mathrm{N}$ \\
\hline & Post & Y & $\mathrm{Y}$ & $\mathrm{Y}$ & NA & $\mathrm{N}$ & $\mathrm{Y}$ & $\mathrm{Y}$ & $\mathrm{N}$ \\
\hline & Ref & $\mathrm{N}$ & $\mathrm{N}$ & $\mathrm{N}$ & $\mathrm{N}$ & $\mathrm{N}$ & $\mathrm{N}$ & $\mathrm{N}$ & $\mathrm{N}$ \\
\hline \multirow{3}{*}{$\begin{array}{l}\text { Vera } \\
\text { Slough }\end{array}$} & Pre & Y & Y & Y & NA & $\mathrm{Y}$ & Y & $\mathrm{N}$ & $\mathrm{N}$ \\
\hline & Post & Y & $\mathrm{Y}$ & $\mathrm{Y}$ & $\mathrm{Y}$ & Y & Y & $\mathrm{Y}$ & Y \\
\hline & Ref & $\mathrm{Y}$ & Y & Y & Y & Y & Y & $\mathrm{N}$ & Y \\
\hline
\end{tabular}

(a) Variable used in the meta-analysis.

Note: Availability is only for the purposes of this meta-analysis. A "no" does not necessarily mean data were not collected. Pre, post, and ref are abbreviations for the existence of data pre- and post- restoration and at reference sites, respectively. The response variables included are not necessarily exhaustive of all data collected at the sites.

\subsubsection{Site Evaluation Cards}

The purpose of Site Evaluation Cards (SECs) is to succinctly summarize the proposed restoration project and its performance relative to key response variables, as shown in the SEC template (Table 3.3). Part 1 of the SEC provides a succinct summary of the problem at the site, the restoration action(s), and the structural and functional conditions prior to restoration. Part 2 of the SEC reports short-term performance of restored sites, from which data can be easily summarized and extracted, and often represents the basic set of information needed to report back to project sponsors and supporting programs. The concept is to use the SEC to report information in support of the cumulative effects analysis, including direct input into the calculation of the net ecosystem improvement (NEI) and cumulative net ecosystem improvement (CNEI). Critical to the meta-analysis is clearly identifying the linkage between the metrics used to assess performance at individual sites and the metrics used for extensive sampling and the higher-order metrics. Future work will include a meta-analysis of the data in the SECs. The overall report card for the projects will prove to be a simple way to communicate basic effectiveness data. However, this would only be useful if practitioners faithfully prepare the report cards based on their monitoring results. 
Table 3.3. Two-Part Template for a Site Evaluation Card. (From the Expert Regional Technical Group for Estuary Habitat Actions: Project Information Template; version 3/25/10.)

\section{PART 1: PROJECT SUMMARY}

\begin{tabular}{|c|c|}
\hline \multicolumn{2}{|l|}{ Header: } \\
\hline \multicolumn{2}{|l|}{$\begin{array}{l}\text { Summary prepared by/date/phone } \\
\text { and email }\end{array}$} \\
\hline \multicolumn{2}{|l|}{$\begin{array}{l}\text { Sponsoring agency/contact/phone } \\
\text { and email }\end{array}$} \\
\hline \multicolumn{2}{|l|}{$\begin{array}{l}\text { Funding agency/contact/phone and } \\
\text { email }\end{array}$} \\
\hline \multicolumn{2}{|l|}{ Site name/location/river/RM } \\
\hline \multicolumn{2}{|l|}{ Current status or stage of the project } \\
\hline \multicolumn{2}{|l|}{ Proposed Project: } \\
\hline Problem statement & $\begin{array}{l}\text { Summarize the site-specific problem(s) the proposed restoration(s) is intended to } \\
\text { address. What is the cause of the problem? }\end{array}$ \\
\hline Vision/goal & $\begin{array}{l}\text { Describe what the site would look like if restoration is successful, i.e., state the expected } \\
\text { outcome. Describe the logic chain from the problem (symptoms) to the proposed } \\
\text { restoration (treatment) to benefits to salmon. }\end{array}$ \\
\hline Objectives & State the project's objectives \\
\hline Project elements(s)/phases by Year & List the proposed restoration ${ }^{(a)}$ action(s) and phase(s) (by year) to meet the objectives. \\
\hline Pre-Assessment: & Whenever possible, provide summary data. \\
\hline Photo Point & $\begin{array}{l}\text { Provide a digital photograph(s) of the site; note the point and orientation of the } \\
\text { photograph, time of year, and tide stage. }\end{array}$ \\
\hline Aerial image & $\begin{array}{l}\text { Provide an aerial image from a satellite or plane. Annotate the image to convey } \\
\text { information about e project. }\end{array}$ \\
\hline Condition of physical metrics & $\begin{array}{l}\text { Describe the major stressors and physical controlling factors. Basically summarize the } \\
\text { existing condition of the site. }\end{array}$ \\
\hline Condition of habitat metrics & Describe the key results of a vegetation survey. \\
\hline Condition of functional metrics & Assess or sample whether juvenile salmonids are present in the area. \\
\hline Performance Anticipated: & If possible, provide target values for various monitored indicators. \\
\hline Physical change & Describe how the action(s) will affect physical controlling factors. \\
\hline Habitat change & Describe the expected condition of habitat. \\
\hline Function change & Describe the expected functional change. \\
\hline Linkage to Estuary Module: & $\begin{array}{l}\text { Present the following information in a table: columns=subactions, rows=module goal, } \\
\text { total project goal, method. }\end{array}$ \\
\hline Estuary Module Action Subaction(s) & See Attachment 1 \\
\hline Subaction Restoration Goal & See Attachment 1 ; note the units (acres or miles) \\
\hline Total Project Goal & $\begin{array}{l}\text { State the acreage or mileage affected by the project as a whole. Document the method } \\
\text { for how the value was obtained. }\end{array}$ \\
\hline Limiting Factors & Summarize the limiting factor(s) identified in the Estuary Module. \\
\hline \multicolumn{2}{|l|}{ Certainty of Success: } \\
\hline Landowner willingness and support & Describe the willingness and support of the landowner. \\
\hline Constraints or show-stoppers & Describe potential issues that could inhibit or prevent execution of the project. \\
\hline Restoration technique & $\begin{array}{l}\text { Describe the level of acceptance and maturity of the restoration technique; e.g., tried } \\
\text { and true or experimental. }\end{array}$ \\
\hline Natural processes & Explain the extent to which natural processes would be restored. \\
\hline Self-maintenance & Explain how well the restoration action(s) are anticipated to be maintained. \\
\hline \multicolumn{2}{|l|}{ Potential Survival Benefits: } \\
\hline $\begin{array}{l}\text { Distance of the project to the main } \\
\text { stem Columbia River }\end{array}$ & State river miles \\
\hline Connectedness to main stem & $\begin{array}{l}\text { Describe how well the project site will be connected to the main stem after the } \\
\text { restoration. }\end{array}$ \\
\hline Adjacent lands & Describe the condition of adjacent lands. \\
\hline Comments & Include comments or other pertinent information. \\
\hline
\end{tabular}


Table 3.3. (contd)

\section{PART 2: PROJECT REPORT CARD}

Construction Date(s)

Was the construction performed as planned? If no, why not?

Actual physical changes realized

\begin{tabular}{|c|c|c|c|c|}
\hline \multicolumn{5}{|l|}{ Monitoring Practitioner(s)/contacts(s) } \\
\hline Post-Construction Assessment & $\begin{array}{c}1 \text { - Yr } \\
\text { Results }\end{array}$ & 1-yr Grade & $\sim 5$-Yr Results & 5-yr Grade \\
\hline \multicolumn{5}{|l|}{ Photo point } \\
\hline \multicolumn{5}{|l|}{ Condition of physical metrics } \\
\hline \multicolumn{5}{|l|}{ Condition of habitat metrics } \\
\hline \multicolumn{5}{|l|}{ Condition of functional metrics } \\
\hline \multicolumn{5}{|l|}{ Actions for adaptive management } \\
\hline \multicolumn{5}{|l|}{ Final assessment ( $\sim 10$ year) } \\
\hline \multicolumn{5}{|l|}{ Was the project successful in meeting its goals? } \\
\hline \multicolumn{5}{|l|}{$\begin{array}{l}\text { If not, what should be changed for future projects of this } \\
\text { type? } \\
\text { Final Performance Grade }\end{array}$} \\
\hline
\end{tabular}

(a) As used here, the term "restoration" refers to conservation, protection, enhancement, restoration, or creation

\subsection{Results}

\subsubsection{Photo Points}

Pre- and post-restoration photo points show changes in vegetation and inundation of water (Figure 3.1). The photo points indicate the sites became more inundated after restoration than before. 


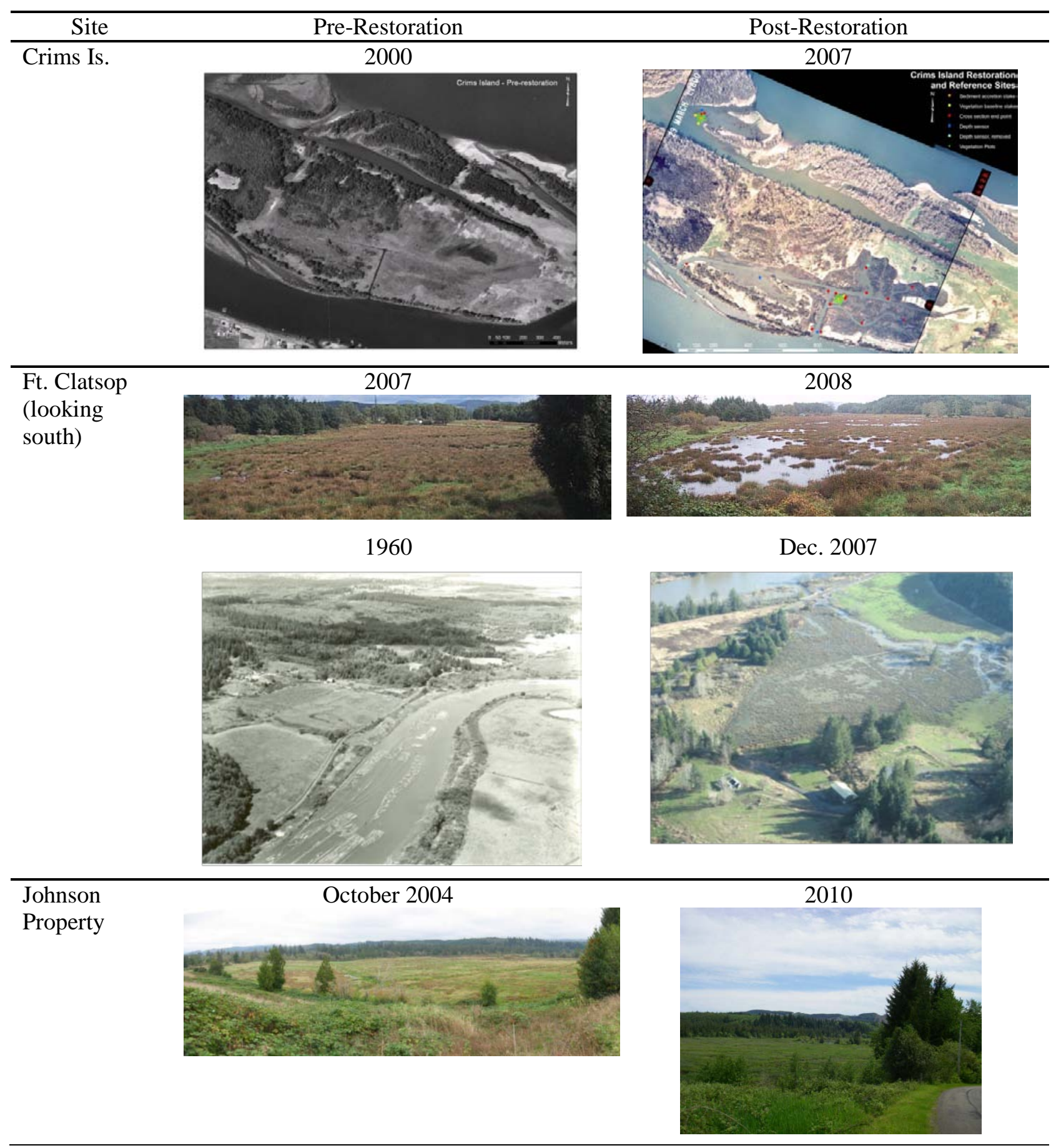

Figure 3.1. Pre- and Post-Restoration Photo Points for the Seven Restoration Projects Included in the Meta-Analysis 

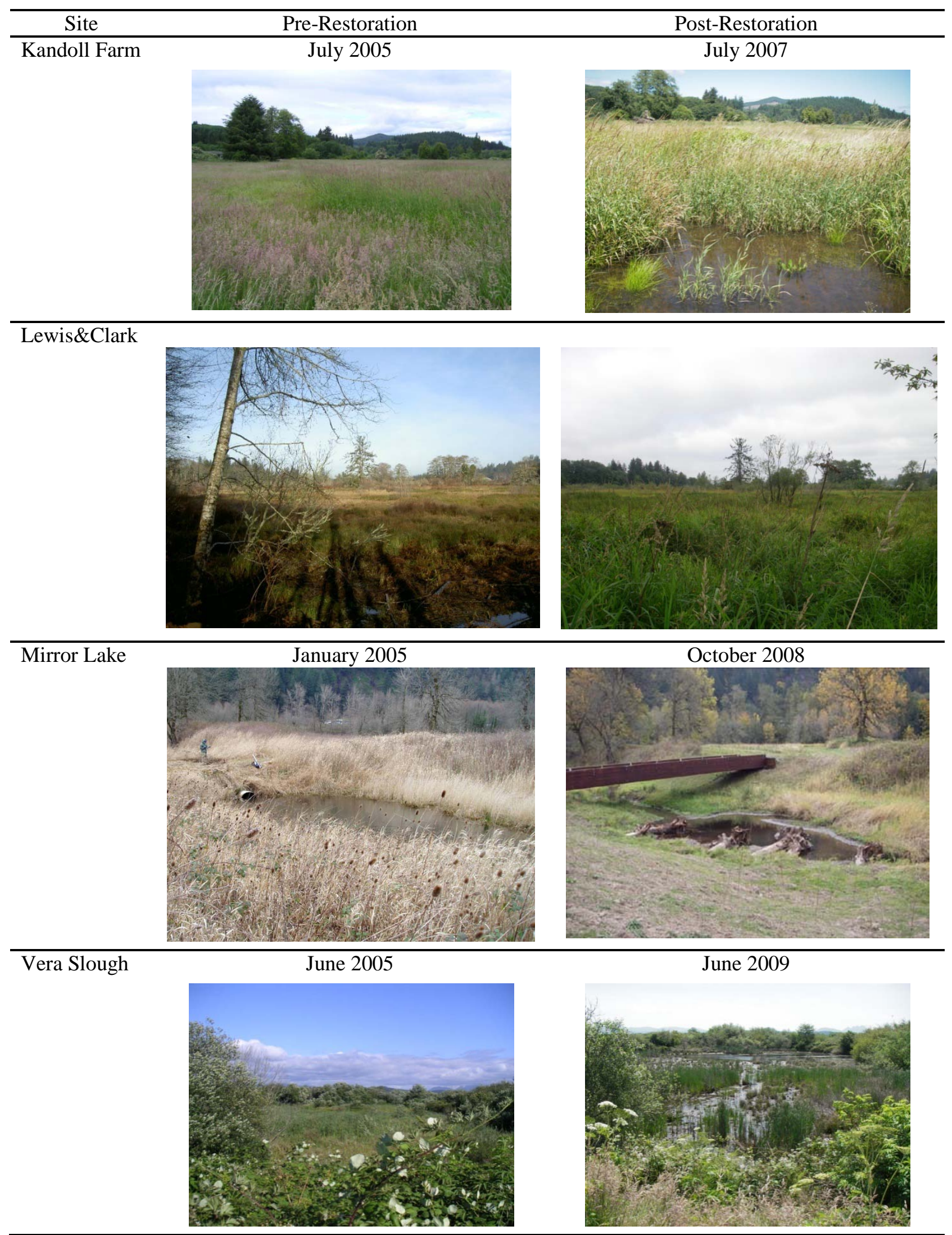

Figure 3.1. (contd) 


\subsubsection{Water Temperature}

Providing cooler water is a key goal for many tidal reconnection activities in the LCRE. Water temperature is an important variable affecting the capacity of restored wetlands to support juvenile salmon. For example, juvenile salmon were rarely captured in trap nets at Kandoll Farm when the water temperature was above $19^{\circ} \mathrm{C}$ (Roegner et al. 2009b).

At Fort Clatsop, water temperatures during June were lower after the restoration action (June 2008) than before (June 2007) (Figure 3.2), but such a comparison should account for changes in the ambient water temperature in adjacent reference site(s). Because no temperature data were available from the reference site for Fort Clatsop, we used temperature data from the Tansy Point sensor in the CORIE network (http://www.ccalmr.ogi.edu/CORIE/) as a comparison for the results at the restoration site. On average, water temperatures were cooler in Columbia River at Tansy Point in June $2008\left(12.73^{\circ} \mathrm{C}\right)$ than in June $2007\left(14.1^{\circ} \mathrm{C}\right)$. Therefore, water temperatures at the restoration site and surrogate reference site at Tansy Point showed the same trend from June 2007 to June 2008.

At Kandoll Farm, $10 \%$ of the water temperature observations were greater than $18.2^{\circ} \mathrm{C}$ in the prerestoration period in August-September 2005, whereas $10 \%$ were greater than $19.7^{\circ} \mathrm{C}$ during the same period 2007 post-restoration (Figure 3.2). At the reference site, mean water temperatures for the August-September period were $17.6^{\circ} \mathrm{C}$ before tidal reconnection in 2005. After tidal reconnection, mean water temperatures were $17.2^{\circ} \mathrm{C}$ in 2006 and $17.1^{\circ} \mathrm{C}$ in 2007 . Water temperatures tended to be cooler following restoration than before restoration. For example, $80 \%$ of temperatures were at or below $20^{\circ} \mathrm{C}$ in pre-restoration as compared to $80 \%$ of temperatures at or below $18^{\circ} \mathrm{C}$ post-restoration. This is probably explained by the greater water exchange with Seal Slough afforded by the open culverts.

Water temperature data were collected at multiple sites within the Mirror Lake restoration site in 2005. Subsequently, annual seasonal water temperature data has been collected since 2008 when intensive action effectiveness monitoring began.

\subsubsection{Sediment Accretion Rate}

Documentation that sediment accretion is occurring verifies that a critical process for rebuilding and maintaining the tidal marshes has been restored or improved. In the year(s) following the restoration activity of hydrologic reconnection, sediment was actively accreting at restoration sites (Table 3.4). At some reference sites, however, sediment was not accreting, or was accreting very slowly (Table 3.4). For example, the Kandoll reference site showed a net loss. Although this site contains some emergent wetland plants and shrubs, the surface of much of the swamp is unvegetated; this condition limits sediment-trapping capacity. 
Ft. Clatsop

Kandoll

Farm
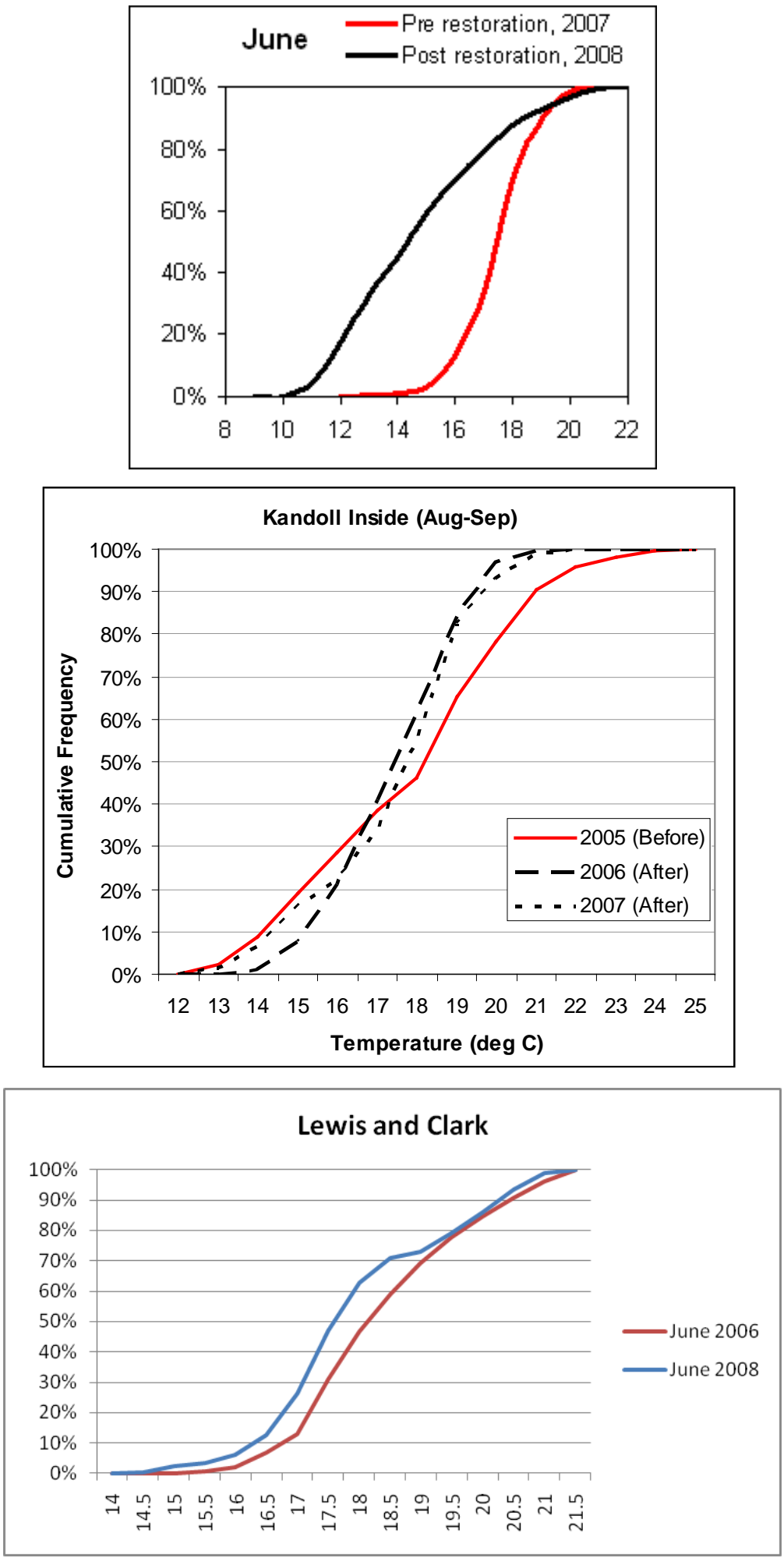

Figure 3.2. Temperature Data Pre- and Post-Restoration 
Table 3.4. Sediment Accretion Rates (cm/y) at Paired Restoration and Reference Sites

\begin{tabular}{|c|c|c|}
\hline & Restoration Site & Reference Site \\
\hline Crims Island ${ }^{(\mathrm{a})}$ & 1.1 & 0.1 \\
\hline Fort Clatsop $^{(b)}$ & -0.2 & 1.0 \\
\hline Johnson Property ${ }^{(\mathrm{c})}$ & 2.1 & NC \\
\hline Kandoll Farm ${ }^{(\mathrm{d})}$ & 2.6 & -0.1 \\
\hline Lewis \& Clark & NC & NC \\
\hline Mirror Lake & NC & NC \\
\hline Vera Slough $^{(\mathrm{e})}$ & 1.2 & 0.45 \\
\hline \multicolumn{3}{|c|}{$\begin{array}{l}\text { NC = data not collected } \\
\text { (a) Crims Island measurements were taken September } 2006 \text { and February } 2007 \text { (Table A.2; Borde et al. } \\
\text { 2008). } \\
\text { (b) Ft. Clatsop reference measurements taken 8/15/08 and 6/25/09; restoration 7/24/08 and spring } 2009 . \\
\text { (c) Johnson Property measurements taken } 2005 \text { and } 2007 \text { (reported in Diefenderfer et al. 2008). } \\
\text { (d) Kandoll Farm measurements taken } 2005 \text { and } 2007 \text { (reported in Diefenderfer et al. 2008). } \\
\text { (e) } 2005-2009 \text { rate from Table } 2.4 \text { of this report. }\end{array}$} \\
\hline
\end{tabular}

\subsubsection{Juvenile Salmon Presence}

At three of the five sites, juvenile salmon were not present before the restoration action but were present after it (Table 3.5). At Fort Clatsop, small numbers of juvenile salmon were present before restoration. In contrast, numbers of salmon increased by an order of magnitude after construction. Vera Slough is located on the west side of Young's Bay. Our sampling at the Vera reference site indicated that few fish seemed to migrate into this area along the western shoreline of the bay. We suspect that this factor may explain the lack of fish presence at the Vera Slough site.

Table 3.5. Pre- and Post-Restoration Juvenile Salmon Presence

\begin{tabular}{lcc}
\hline & Pre-Restoration & Post-Restoration \\
\hline Crims Island & No & Yes \\
Ft. Clatsop & Yes (sparse) & Yes (abundant) \\
Johnson Property & No & Yes \\
Kandoll Farm & No & Yes \\
Lewis \& Clark River & No & Yes \\
Mirror Lake & Unk. & Yes \\
Vera Slough & No & No \\
\hline
\end{tabular}

At the Mirror Lake site, juvenile salmonids have been detected since seasonal effectiveness monitoring began in 2008. Sampling occurs April through September, while juvenile Chinook are only found at the site until May, although very low numbers have been found in June and July. Oregon Department of Fish and Wildlife spawning surveys list the creeks above the restoration site as spawning areas for lower Columbia River coho, and Estuary Partnership/NMFS/Bonneville Power Administration monitoring have found wild coho in the creeks throughout the summer months. 


\subsubsection{Site Evaluation Cards}

Completion of Site Evaluation Cards for the seven sites in the meta-analysis has been attempted. The cards include two parts: a project summary and a project report card. The main lesson learned is that SECs should be filled out by project sponsors during the project development phase. Post-hoc work on the SECs is problematic because other work has higher, immediate priority.

\subsubsection{Summary and Recommendations}

In summary, the seven restoration actions studied are generally producing favorable results in terms of the photo point, water temperature, sediment accretion, and juvenile salmon presence. From lessons learned during this process, we make the following recommendations:

- Photo points need to be collected diligently and purposefully for pre- and post-restoration conditions.

- Water temperature data need to be normalized to ambient river conditions.

- Sediment accretion rates, while relatively easy to sample, should be a priority in the monitoring plan.

- Juvenile salmon presence provides compelling evidence for the success or failure of a tidal reconnection restoration. Data on estimates of genetic stock identification will further elucidate restoration effectiveness at selected sites.

- Preparing the SECs requires time and dedicated and knowledgeable staff. The process is not trivial; it should be started early in the restoration planning process and updated as new information becomes available. 



\subsection{Conclusions and Recommendations}

This section contains conclusions about the 2009 work related to fish and hydrography, vegetation elevation (site-specific and estuary-wide), material exchange, action effectiveness meta-analysis, and historical breaches and created sites and recommendations for 2010 study.

\subsection{Conclusions}

The following conclusions are based on 2009 results reported in Sections 2 and 3 and Appendices A through C.

\section{Fish and Hydrography}

- Large numbers of juvenile chum salmon were sampled in the tidal channels at the Kandoll restoration site, implying that the sampling covered the main outmigration.

- As in previous years, juvenile Chinook salmon were present in the trap-net samples in low numbers.

- Coho salmon sampling included fry, subyearling, and yearling fishes. Marked fish from the Grays hatchery were captured at Kandoll Farm.

\section{Vegetation Elevation}

- The elevations of vegetation are higher at the restoration site than at the reference site at both Kandoll Farm and Vera Slough. At Crims Island, the elevations are the same between restoration and reference sites.

- As a corollary, accretions rates are higher at restoration sites than at reference sites.

- All tidal wetlands examined in this study exist within a 3-m vertical range, which increases as longitudinal distance upstream from the Columbia River mouth increases.

- Channel density is not likely a good indicator of habitat development where preexisting channels are present, but it may be a useful indicator for constructed wetlands.

- Channel cross-sectional area typically changes most at the mouth proximal to the restoration action.

- Reed canary grass has become the dominant plant at the Kandoll restoration site. At the Crims Island restoration site, the proportion of reed canary grass is increasing (30\% in 2009). At the Vera Slough restoration site, on the other hand, bare ground has the highest percent cover.

- The four swamps studied have the same dominant tree species: Sitka spruce, red alder, Western red cedar, western hemlock.

- Line-intercept data from Kandoll Farm during 2009 show 26 herbaceous plant species that were not present in 2005-2006.

\section{Exchange}

- At the intensive material-exchange study site at Kandoll Farm during April 2009, inorganic suspended sediments were the predominant component of TSSs during both spring- and neap-tides series sampling. 
- There was a higher ( 30\%) maximum TSS concentration during spring tides than during neap tides. TSS concentration was also more variable during spring than neap tides. The concentration of organic suspended sediment during neap-ebb tides was 32\% of the total TSS compared to the neapflood tide at $23 \%$ of total TSS.

- The largest flux of neuston macrodetritus was during an ebb tide $\left(90 \mathrm{~g} / \mathrm{m}^{3}\right)$; typical concentrations were 20 to $30 \mathrm{~g} / \mathrm{m}^{3}$.

- Fish captured with the neuston-net included chum and stickleback during both ebb and flood tides. Highest concentration for stickleback was on a flooding tide; chum had comparable concentrations during ebb and flood.

- During the neap-tide series, water velocities were too low to collect neuston-net data.

\section{Action Effectiveness Meta-Analysis}

- The seven restoration actions studied are generally producing favorable results in terms of the photo point, water temperature, sediment accretion, and juvenile salmon presence.

- Preparing the SECs requires time and dedicated and knowledgeable staff. The process is not trivial; it should be started early in the restoration planning process and updated as new information becomes available.

\section{Wetted Area Modeling}

- Habitat opportunity can be evaluated by quantifying wetted area, frequency, and duration of inundation using a GIS-based time-area inundation index.

- The methods developed in this study provide a means to evaluate habitat opportunities at proposed restoration sites, monitor change in existing restoration sites, understand inundation impacts under representative/altered flow regimes, determine trade-offs between water-surface elevation and habitat opportunity, and provide a standardized functional metric for site comparisons.

- Restored diked sites tend to be subsided and therefore have a greater frequency of inundation than the corresponding reference sites.

\section{Vegetation Elevation Estuary-Wide}

- There is higher plant species richness in tidal freshwater areas in the mid-LCRE (rkm 60-100) than elsewhere up or downstream.

\section{Historical Breaches and Created Sites}

- Juvenile Chinook salmon were found at all historical breaches and created sites and, overall, were second in abundance to stickleback.

- Size frequency distributions of juvenile salmon were similar between sites inside and outside the breach. Based on size data, all Chinook salmon sampled were subyearling fishes. Both wild and hatchery-reared salmon were using the historical breaches and created sites. 


\subsection{Recommendations}

Recommendations for the 2010 study, the final year of the project, are to do the following:

1. Summarize the ecological relationships established during the course of the study and identify remaining critical uncertainties.

a. Evaluate the effectiveness of the three, paired sets of restoration and reference sites monitored since the outset of the study, representing dike breaching, tide-gate replacement, and culvert installation methods at the Crims Island, Kandoll Farm, Vera Slough sites.

b. Perform estuary-wide meta-analysis of cumulative net ecosystem improvements using effectiveness monitoring data from estuary habitat restoration projects collected following the protocols developed by the project and completing data gaps wherever possible.

c. Project the cumulative net ecosystem effect in GIS using values from the literature and the project monitoring data for a set of estuary-wide restoration scenarios developed in collaboration with the USACE and its partners.

d. Assuming appropriate estuary-wide model data are available from others, examine the potential for synergistic effects of restoration project spatial configuration and temporal sequencing on critical response variables (e.g., wetted habitat area).

2. Synthesize the levels of evidence for a cumulative effects assessment based on 2005-2010 study results and an updated state-of-the-science literature review.

3. Support the USACE to implement an adaptive management framework including the cumulative effects method, specific recommendations for infrastructure, and the 2005-2009 data package to support periodic evaluations of LCRE cumulative effects.

a. Draft a cumulative effects implementation manual including topics such as a sampling design to conduct intensive and extensive monitoring, data-management guidelines, and a responsibilities matrix.

b. Convene technology-transfer and outreach meetings with LCRE restoration practitioners to seek input on their requirements and needs to implement cumulative effects methodology.

c. Conduct a cumulative effects methodology workshop at the 2011 National Conference on Ecosystem Restoration. 



\subsection{Literature Cited}

American Public Health Association (APHA). 1998. 20th Edition, Washington, D.C.

Bottom, DL, CA Simenstad, J Burke, AM Baptista, DA Jay, KK Jones, E Casillas, and MH Schiewe. 2005. Salmon at River's End: the Role of the Estuary in the Decline and Recovery of Columbia River Salmon. National Oceanic and Atmospheric Administration (NOAA) Technical Memorandum. NMFS-NWFSC-68, NOAA National Marine Fisheries Service, Seattle, Washington.

Busch, DE and JC Trexler, eds. 2003. Monitoring Ecosystems-Interdisciplinary Approaches for Evaluating Ecoregional Initiatives. Island Press, Washington, D.C.

Diefenderfer, HL and DR Montgomery. 2008. "Pool spacing, channel morphology, and the restoration of tidal forested wetlands of the Columbia River, U.S.A.” Restoration Ecology 17:158-168.

Diefenderfer, HL, GC Roegner, RM Thom, EM Dawley, AH Whiting, GE Johnson, KL Sobocinski, MG Anderson, and BD Ebberts. 2005. Evaluating Cumulative Ecosystem Response to Restoration Projects in the Columbia River Estuary, Annual Report 2004. PNNL-15102, prepared by Pacific Northwest National Laboratory, Richland, Washington, for the U.S. Army Corps of Engineers, Portland District, Portland, Oregon.

Diefenderfer, HL, AM Coleman, AB Borde, and IA Sinks. 2008. "Hydraulic geometry and microtopography of tidal freshwater forested wetlands and implications for restoration, Columbia River, U.S.A.” Ecohydrology and Hydrobiology 8:339-361.

Diefenderfer, HL, GE Johnson, JR Skalski, RM Thom, SA Breithaupt and AM Coleman. In Revision. "Diminishing Returns of Dike Breaching in the Restoration of Tidal Floodplain Habitat Area." Restoration Ecology.

Diefenderfer, HL, RM Thom, AB Borde, GC Roegner, AH Whiting, GE Johnson, EM Dawley, JR Skalski, J Vavrinec, and BD Ebberts. 2006. Evaluating Cumulative Ecosystem Response to Restoration Projects in the Columbia River Estuary, Annual Report 2005. PNNL-15934, prepared by Pacific Northwest National Laboratory, Richland, Washington, for the U.S. Army Corps of Engineers, Portland District, Portland, Oregon.

Downes, BJ, LA Barmuta, PG Fairweather, DP Faith, MJ Keough, PS Lake, BD Mapstone, and GP Quinn. 2002. Monitoring Ecological Impacts: Concepts and Practice in Flowing Waters. Cambridge University Press, Cambridge, United Kingdom.

Endangered Species Act. 16 USC 1531 et seq.

Fresh, KL, E Casillas, LL Johnson, and DL Bottom. 2004. Role of the Estuary in the Recovery of Columbia River Basin Salmon and Steelhead: An Evaluation of Selected Factors on Population Viability. National Oceanic and Atmospheric Administration (NOAA) Technical Memorandum, Northwest Fisheries Science Center, National Marine Fisheries Service, NOAA, Seattle, Washington (May 2004). 
Johnson, GE (ed.). 2007. Evaluating Cumulative Ecosystem Response to Restoration Projects in the Columbia River Estuary, Annual Report 2006. PNNL-16561, prepared by Pacific Northwest National Laboratory, Richland, Washington, for the U.S. Army Corps of Engineers, Portland District, Portland, Oregon.

Johnson, GE and HL Diefenderfer (eds.). 2008. Evaluating Cumulative Ecosystem Response to Restoration Projects in the Columbia River Estuary, Annual Report 2007. PNNL-17437, prepared by Pacific Northwest National Laboratory, Richland, Washington, for the U.S. Army Corps of Engineers, Portland District, Portland, Oregon.

Johnson, GE and HL Diefenderfer (eds.). 2009. Evaluating Cumulative Ecosystem Response to Restoration Projects in the Lower Columbia River and Estuary, 2008. PNNL-18677, prepared by Pacific Northwest National Laboratory, Richland, Washington, and the National Marine Fisheries Service, Seattle, Washington, for the U.S. Army Corps of Engineers, Portland District, Portland, Oregon.

Johnson, GE, HL Diefenderfer, BD Ebberts, C Tortorici, T Yerxa, J Leary, and J Skalski. 2008. Research Monitoring and Evaluation for the Federal Columbia River Estuary Program. PNNL-17300, final report by the Pacific Northwest National Laboratory, Richland, Washington, for the Bonneville Power Administration, Portland, Oregon.

Johnson, GE, RM Thom, AB Borde, HL Diefenderfer, K Jones and C Corbett. 2009. "Effectiveness Monitoring Data—Preliminary Meta-Analysis.” Appendix H, in: Evaluating Cumulative Ecosystem Response to Restoration Projects in the Lower Columbia River and Estuary, 2008, eds. GE Johnson and HL Diefenderfer. PNNL-18677, prepared by Pacific Northwest National Laboratory, Richland, Washington, and the National Marine Fisheries Service, Seattle, Washington, for the U.S. Army Corps of Engineers, Portland District, Portland, Oregon.

Johnson, GE, RM Thom, AH Whiting, GB Sutherland, T Berquam, BD Ebberts, NM Ricci, JA Southard, and JD Wilcox. 2003. An Ecosystem-Based Approach to Habitat Restoration Projects with Emphasis on Salmonids in the Columbia River Estuary. PNNL-14412, prepared by Pacific Northwest National Laboratory, Richland, Washington for the Bonneville Power Administration, Portland, Oregon.

Maier, GO and CA Simenstad. 2009. "The role of marsh-derived macrodetritus to the food webs of juvenile Chinook salmon in a large altered estuary.” Estuaries and Coasts 32:984-998.

McCune, B and JB Grace. 2002. Analysis of Ecological Communities. Gleneden Beach, Oregon: MJM Software Design. www.pcord.com

Mitsch, WJ and JG Gosselink. 2000. "The value of wetlands: Importance of scale and landscape setting.” Ecological Economics 35(1):25-33.

May, C and D Geist. 2007. Grays River Watershed and Biological Assessment, 2006 Final Report. Project No. 200301300, 551 electronic pages, BPA Report DOE/BP-00000652-38, Bonneville Power Administration, Portland, Oregon. 
National Oceanic and Atmospheric Administration (NOAA) Fisheries. 2008. Biological OpinionConsultation on Remand for Operation of the Federal Columbia River Power System, 11 Bureau of Reclamation Projects in the Columbia Basin and ESA Section 10(a)(1)(A) Permit for Juvenile Fish Transportation Program. National Marine Fisheries Service (NOAA Fisheries) - Northwest Region. Seattle, Washington.

Parsons, TR, Y Maita, and CM Lalli. 1984. A Manual of Chemical and Biological Methods for Seawater Analysis. Pergamon Press, New York.

Peet, RK, TR Wentworth, and PS White. 1998. “A flexible, multipurpose method for recording vegetation composition and structure.” Castanea 63:262-274.

Richter, A and SA Kolmes. 2005. "Maximum temperature limits for Chinook, coho, and chum salmon, and steelhead trout in the Pacific Northwest.” Reviews in Fisheries Science 13:23-49.

Roegner, GC, HL Diefenderfer, AB Borde, RM Thom, EM Dawley, AH Whiting, SA Zimmerman, and GE Johnson. 2009a. Protocols for Monitoring Habitat Restoration Projects in the Lower Columbia River and Estuary. NOAA Technical Memorandum NMFS-NWFSC-97, prepared by NOAA Fisheries and Pacific Northwest National Laboratory for the U.S. Army Corps of Engineers, Portland District. Seattle, Washington.

Roegner, GC, M Russell, and EM Dawley. 2009b. Hydrology and Fish - Monitoring Data Summary.” Appendix E, in: Evaluating Cumulative Ecosystem Response to Restoration Projects in the Lower Columbia River and Estuary, 2008. GE Johnson and HL Diefenderfer (eds.). PNNL-18677, prepared by Pacific Northwest National Laboratory, Richland, Washington, and the National Marine Fisheries Service, Seattle, Washington, for the U.S. Army Corps of Engineers, Portland District, Portland, Oregon.

Roegner, GC, EW Dawley, M Russell, AH Whiting, and DJ Teel. 2010. “Juvenile Salmonid Use of Reconnected Tidal Freshwater Wetlands in Grays River, Lower Columbia River Basin.” Transactions of the American Fisheries Society 139:1211-1232

Simenstad, CA, CD MacIntire, and LF Small. 1990. "Consumption processes and food web structure in the Columbia River estuary.” Progress in Oceanography 25:271-297.

Small, LF. 1990. “Columbia River: Estuarine System.” Special Issue. Progress in Oceanography 25:1-4.

Thom, RM, GC Roegner, J Vavrinec, and BD Ebberts. 2008. “Material Flux - Monitoring Data Summary.” Appendix D, in: Evaluating Cumulative Ecosystem Response to Restoration Projects in the Lower Columbia River and Estuary, Annual Report 2007. GE Johnson and HL Diefenderfer (eds), PNNL-17437, prepared by Pacific Northwest National Laboratory, Richland, Washington, for the U.S. Army Corps of Engineers, Portland District, Portland, Oregon.

Thomas, DW. 1983. “Changes in the Columbia River estuary habitat types over the past century.” Columbia River Estuary Data Development Program, Columbia River Estuary Study Task Force, Astoria, Oregon. 
U.S. Environmental Protection Agency (EPA). 2003. EPA Region 10 Guidance for Pacific Northwest State and Tribal Temperature Water Quality Standards. EPA 910-B-03-002, Region 10 Office of Water, Seattle, Washington. 


\section{Appendix A}

\section{Spatially Based Area-Time Inundation Index Model Applied in Tidal Wetlands of the Lower Columbia River and Estuary}





\title{
Appendix A - Spatially Based Area-Time Inundation Index Model Applied in Tidal Wetlands of the Lower Columbia River and Estuary
}

\author{
Prepared by André M. Coleman, Heida L. Diefenderfer, Duane L. Ward, and Amy B. Borde
}

\section{A.1 Abstract}

The hydrodynamics of floodplain areas in the lower Columbia River and estuary (LCRE) directly impact habitat quality and opportunity for endangered salmonids. Inundation patterns throughout the estuary are primarily influenced by tidal cycles, hydro system operations, climate, and physical barriers such as dikes and tide gates. These patterns are controlling factors in the development of physical and biological structure, including fluxes through the terrestrial and aquatic systems. Ongoing wetland/riparian restoration efforts are intended to increase available habitat opportunity through hydrologic reconnection between main stem river channels and diked areas of the historical river floodplain. The habitat opportunity can be evaluated by quantifying wetted area, frequency, and duration of inundation. A geographic information system (GIS)-based area-time inundation index model was developed that integrates 1) advanced terrain processing of Light Detection and Ranging (LiDAR) data to reveal the microtopography of floodplain zones, 2) continuously collected and elevation-surveyed water level sensor data, and 3) a wetted area algorithm to determine areal inundation extent. The area-time inundation index is calculated as the number of hectare-hours of inundation, including both in-channel and floodplain area, summed at 10-cm increments and divided by the total possible hectare-hours for each site. These methods provide a means to evaluate habitat opportunities at proposed restoration sites, monitor change in existing restoration sites, understand inundation impacts under representative/altered flow regimes, determine trade-offs between water-surface elevation and habitat opportunity, and provide a standardized functional metric for site comparisons. Results of this modeling effort are presented for seven areas in the LCRE including tidal marsh, forested wetland, and restoration sites.

\section{A.2 Introduction}

Riparian zones represent a biodiverse and dynamic ecotone possessing specific processes attributable to the interface between terrestrial and aquatic ecosystems (Naiman and Décamps 1997). The hydrologic regime of riparian zones has been altered by flow regulation, changes in available snowpack, and channel fragmentation, which have strongly affected many large river systems and fisheries of the world (Dynesius and Nilsson 1994; Mote et al. 2005; Battin et al. 2007). Although a large number of river restoration projects have been initiated in an attempt to recover the values associated with riparian zones, monitoring and evaluation of the outcome of these efforts is often negligible (Bernhardt et al. 2007).

Recommendations for wetland restoration monitoring typically include sampling biological metrics such as vegetation type and mass combined with physical metrics such as soils, water quality, topography, and hydrology (Callaway et al. 2001). In river floodplain wetlands, the flow regime is a major determinant of the physical and, in turn, biotic components of the ecosystem (Bunn and Arthington 2002). The flora and fauna are adapted to a complicated suite of spatiotemporal interactions between the land and the water (Welcomme 1979; Junk 1999), and the reestablishment of something like this natural 
disturbance regime is necessary for ecosystem restoration to succeed (Poff et al. 1997). The strategic reconnection of rivers and floodplains at large scales has been recommended to regain the values associated with floodplain ecosystems (Opperman et al. 2009). Thus, practitioners of ecological restoration in these transitional ecosystems need tools to measure the effects of actions on various existing and predicted hydrologic regimes.

The total area and time of water inundation over a restoration site or entire riverscape can provide a simple index of habitat opportunity and improve our understanding of potential rates of ecosystem subsidies such as nutrients that flux between the floodplain and channel network (Polis et al. 1997; Welcomme 2008). However, disturbance regimes may also be more carefully described using additional parameters (e.g., frequency and magnitude) (White and Pickett 1985). The fluctuations in water level are controlling factors in the development of physical and biological community structures, but they may have predictable and unpredictable components that are challenging to measure (Toth 1995; Junk 1999).

The characterization of inundation patterns is yet more complex in managed lower river floodplains where tidal influences are mixed with hydro system operations and the dynamics of seasonal and climate influenced flows, such as in the case of the lower Columbia River on the West Coast of North America (see Figure A.1). In the LCRE, juvenile salmonids use shallow wetted areas to rear, feed, and rest, but the managed hydrograph and passage barriers diminish the opportunities for fish to enter tidal wetlands (Bottom et al. 2005). Diking and a more than $40 \%$ reduction in flow during the spring freshet (May-July) has reduced the shallow water habitat area available to juvenile salmonids in the LCRE by approximately $62 \%$ according to modeled estimates (Kukulka and Jay 2003). Thus, the reconnection of lateral floodplain habitats with the mainstem river by breaching dikes and removing/replacing culverts and tide gates is an important element of landscape-scale restoration programs currently underway on the river (Johnson et al. 2008).

A variety of methods for the quantification of the inundation regime of floodplain wetlands have been reported in the literature, with typical examples including direct measurement of water levels onsite using data-logging pressure gauges for surface water and piezometers for groundwater, and the construction of stage-discharge curves relating river discharge to water elevation (e.g., Siebentritt et al. 2004). The hydrologic parameter developed from such measurement methods depends on the purpose of the study. For example, patterns of discharge and recharge in groundwater flow have been assessed using piezometers and paired shallow wells to characterize reference wetland hydrologic conditions (Ehrenfeld et al. 2003). To predict sediment transport events, Florsheim et al. (2006) calculated flow-duration curves because the process depends on both magnitude and duration of overbank flooding. Welcomme (2008) advocates the use of maximum area flooded over the course of a year as the best predictor of fish production, which for very large rivers such as the Amazon can be quantified using remote sensing methods. The coefficient of variation of mean monthly water depth over the 8-month growing season, which indicates the relative fluctuation of water levels and ponding duration, was a good predictor of vegetation type in coastal depressional wetlands (De Steven and Toner 2004). Methods range from the complex and expensive, e.g., hydrodynamic modeling (Silvestri et al. 2004), to the simple, e.g., the number of months per year during which standing water is present, as observed during monthly visits to the site (Meyer et al. 2008). 


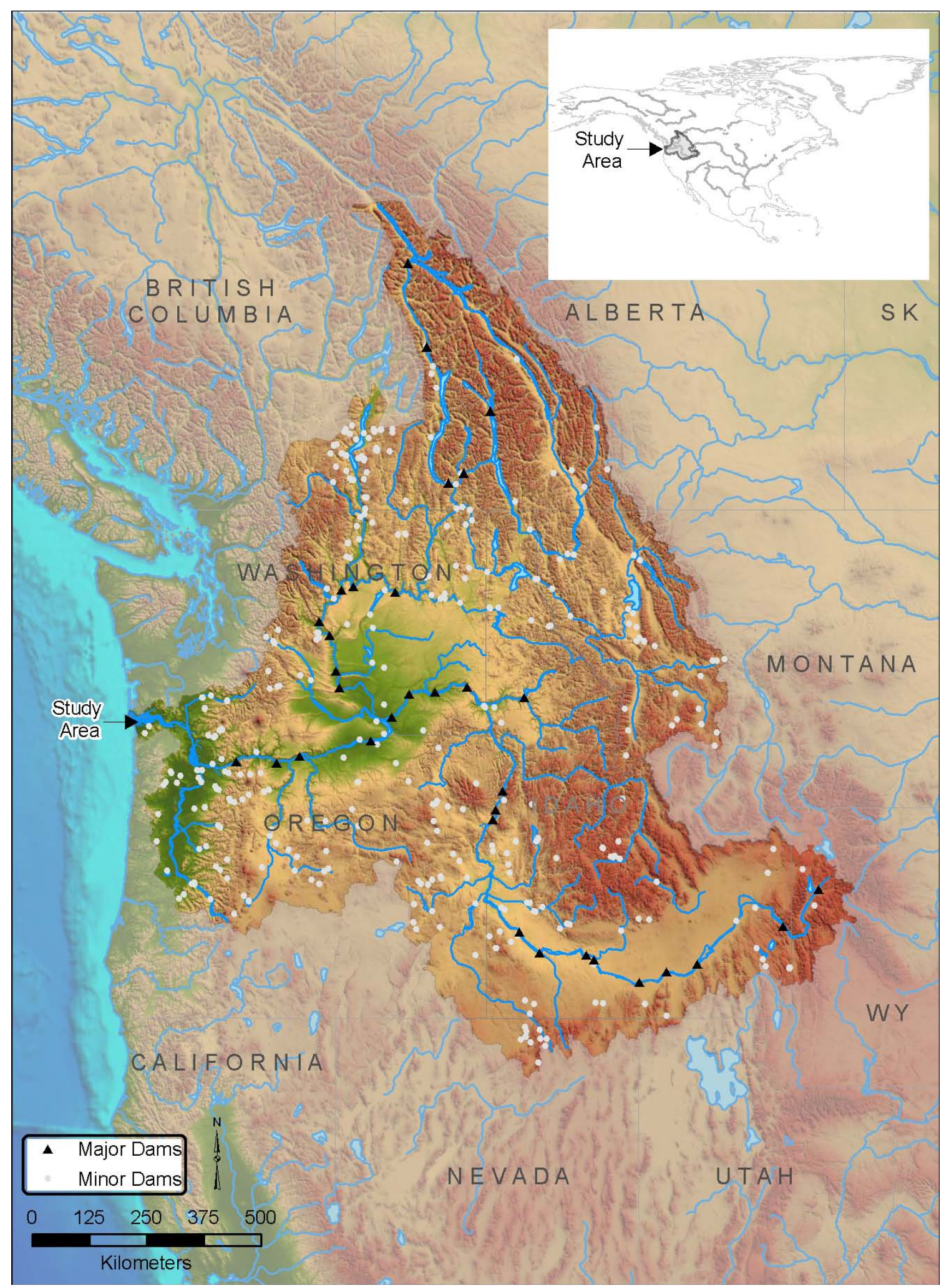

Figure A.1. The Columbia River Watershed Spans Several States and a Province and Includes 32 Major Dams and Approximately 100 Minor Dams 
In this paper, we present a method that couples high-resolution terrain data, in situ water-level data, and a GIS-based wetted area algorithm that captures spatial and temporal inundation patterns to 1) quantify habitat opportunities at existing and proposed restoration sites, 2) understand change over time at existing restoration sites, 3) reveal inundation impacts under seasonal/climate/hydro system altered flow regimes, 4) understand trade-offs between temporal water-surface elevation and available habitat opportunity, and 5) provide a common metric for local or landscape-scale site comparisons. This method was applied to seven sites throughout the LCRE, including tidal marsh, forested wetland, and restoration sites (see Figure A.2). A characterization of each of the sites is included in Table A.1.

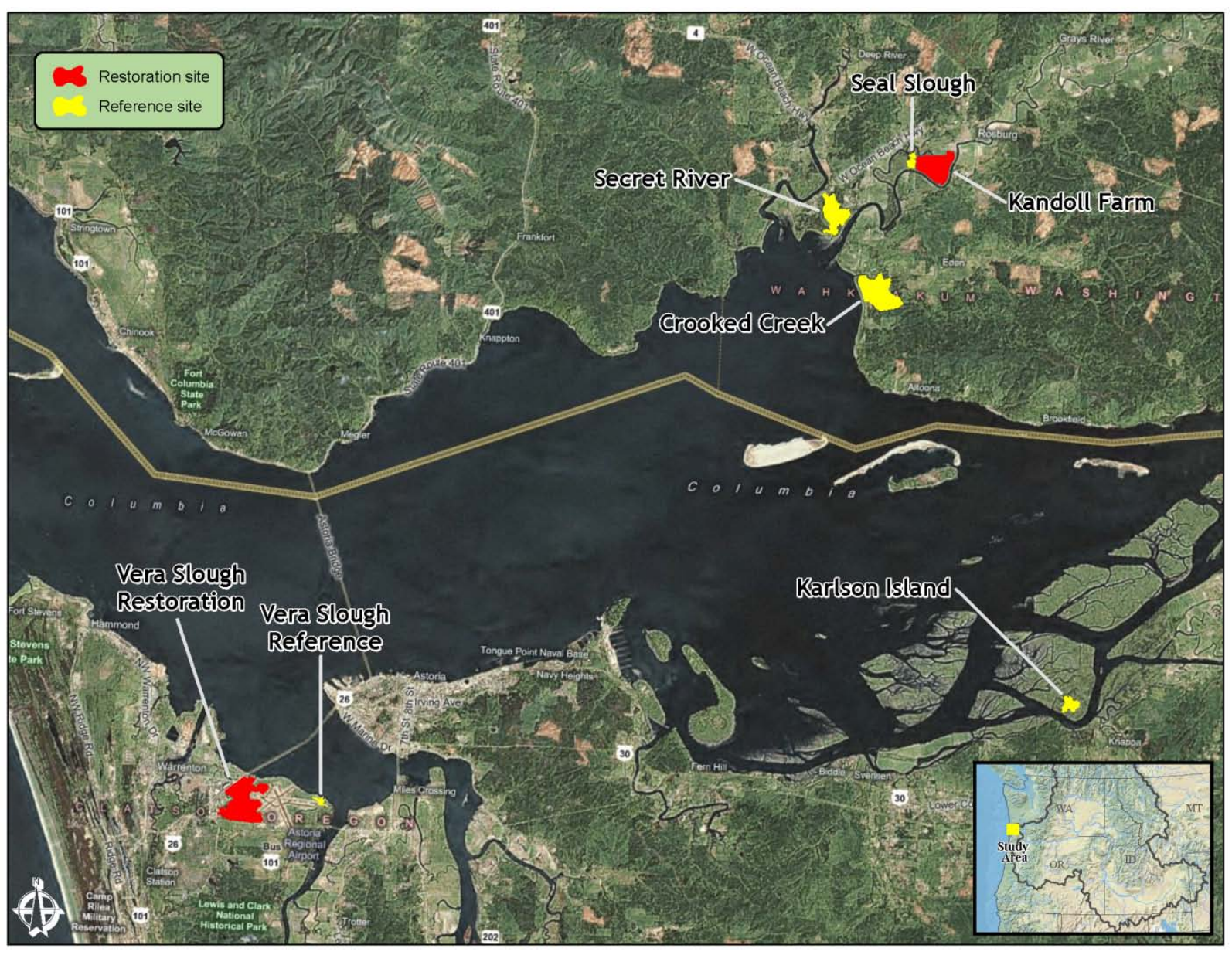

Figure A.2. The Seven Sites in the Lower Columbia River and Estuary Include Tidal Marsh, Forested Wetland, and Restoration Sites 
Table A.1. Water-Level Sensor Sites, Characterization, and Dates of Collection

\begin{tabular}{clll}
\hline \multicolumn{1}{c}{ Site Group } & \multicolumn{1}{c}{ Site } & \multicolumn{1}{c}{ Characterization } & Dates of Collection \\
\hline Grays River & Kandoll Farm $^{(\mathrm{a})}$ & Formerly diked pastureland (restoration) & $07 / 11 / 2005-03 / 10 / 2008$ \\
& Seal Slough $^{(\mathrm{a})}$ & Sitka spruce swamp (reference) & $06 / 10 / 2005-03 / 11 / 2008$ \\
& Secret River & Sitka spruce swamp (reference) & $07 / 30 / 2007-06 / 29 / 2008$ \\
& Crooked Creek $^{\text {Youngs Bay }}$ & Sitka spruce swamp (reference) & $08 / 01 / 2007-07 / 03 / 2008$ \\
& Vera Reference $^{(\text {a) }}$ & Emergent marsh (reference) & $12 / 01 / 2007-06 / 30 / 2008$ \\
& Vera Slough $^{(a)}$ & Wetland enhancement w/ tide-gate & $04 / 19 / 2007-08 / 20 / 2009$ \\
Cathlamet Bay & Karlson Island & replacement (restoration) & \\
\hline
\end{tabular}

(a) Sensors remain active; this table represents the most recent gathered and processed data.

\section{A.3 Study Area}

The LCRE is a drowned-river valley characterized by mixed semi-diurnal tides and has been classified as meso-tidal (Sherwood and Creager 1990). Historically, unregulated flows were estimated to range from a minimum of $2,237 \mathrm{~m}^{3} / \mathrm{s}(79,000 \mathrm{cfs})$ in the fall to maximum flood flows of over $28,317 \mathrm{~m}^{3} / \mathrm{s}$ (1 million cfs) during spring freshets (Sherwood et al. 1990). Since the 1930s, however, the timing of the Columbia River's discharge has been progressively regulated due to construction and operation of 32 major dams and approximately 100 minor dams on the river's main stem and tributaries that reduce spring freshet flows and increase fall/winter flows (see Figure A.1). Recently, it has been shown that due to air temperatures at an average increase of $1.5^{\circ} \mathrm{F}$ between 1920 and 2003 and a higher density of particulates (e.g., soot, dust) found in the snowpack (Qian et al. 2009; Mantua et al. 2010), the snow water equivalent as measured on April 1 has declined significantly from what has been observed historically in the Pacific Northwest (Mote et al. 2005), thereby realizing additional forcing factors for the downriver hydrograph. Alterations in the physical processes of the estuary that are attributable to human intervention include decreased freshwater discharge rates, tidal prism, and mixing; and increased flushing time and fine sediment deposition, resulting in a net accumulation of sediment (Sherwood et al. 1990).

The tidal range in the estuary is relatively large at $3.6 \mathrm{~m}$ and affects water levels throughout the entire lower reach to Bonneville Dam (river kilometer [rkm] 235) (Neal 1972; Sherwood and Creager 1990). While tidal influence extends to Bonneville Dam, the extent of saltwater intrusion, or the boundary of the estuarine area, is approximately $20 \mathrm{~km}$ to $40 \mathrm{~km}$ depending on seasonal flows (Chawla et al. 2008). Estuary flushing time has been calculated using several methods; calculations using a river flow of $15.5 \times 10^{7} \mathrm{~m}^{3} /$ tidal cycle $\left(549 \times 10^{7} \mathrm{ft}^{3} /\right.$ tidal cycle) and maximum salinity intrusion of $35 \mathrm{~km}$ (19 nautical miles), for example, predict total flushing time ranging from 4.97 tidal cycles using the fraction-offreshwater method to 9.0 tidal cycles using the modified tidal-prism method (Neal 1972). As an extension of the physical processes associated with the LCRE, the Columbia River plume is a dominant factor affecting the hydrography of Pacific Northwest coastal waters (Garcia-Berdeal et al. 2002; Hickey and Banas 2003).

For the purpose of a change analysis from 1870 to present, Thomas (1983) found that only five habitat types could be delineated from the available historical data. In order by elevation from highest to lowest, these are tidal swamps, tidal marshes, shallows and flats, medium-depth water, and deep water. Thomas mapped habitat loss and conversion of these habitat types in seven subareas: the river mouth, 
mixing zone, Youngs Bay, Baker Bay, Grays Bay, Cathlamet Bay, and the upper estuary (Thomas 1983). Significant to juvenile salmon habitat requirements is that below Puget Island (rkm 71) the area of tidal swamps has been reduced by $77 \%$, and $65 \%$ of the 1,870 tidal marshes have been lost while new marshes totaling about $22 \%$ of the original area have been formed (a net loss of $43 \%$ ) (Thomas 1983). The study also showed net losses of medium-depth and deep water habitats (35\% and 7\%, respectively), and a gain of shallows and flats caused mostly by shoaling in formerly deeper water areas (10\%).

The present study includes three of the tidal regions characterized by Thomas (1983): Youngs Bay (rkm 19), Grays River (rkm 34), and Cathlamet Bay (rkm 29). The Youngs Bay site includes a 0.04-km² reference emergent marsh and a $1.06-\mathrm{km}^{2}$ wetland that was enhanced by an experimental tide-gate replacement in 2005. The Grays River site includes three reference Sitka spruce (Picea sitchensis) swamps $\left(0.08 \mathrm{~km}^{2}-0.78 \mathrm{~km}^{2}\right)$ and a $0.66-\mathrm{km}^{2}$ formerly diked pastureland that underwent dike breach and culvert replacement restoration in 2005. The Cathlamet Bay site is a fourth Sitka spruce swamp $\left(0.15 \mathrm{~km}^{2}\right)$ that is located on Karlson Island.

\section{A.4 Methods and Results}

\section{A.4.1 Water Level Measurements}

To document changes in water-surface elevations for reference sites and before and after restoration and enhancement actions, $\mathrm{HOBO}^{\circledR}$ model U20 water-level logger absolute pressure sensors were installed in reference channels and channels where culvert installation, tide-gate replacement, and dike breaching were to occur. The water-level pressure data were recorded hourly and converted to water-surface elevations, reported as orthometric heights in the North American Vertical Datum of 1988 (NAVD88), by correcting for atmospheric pressure and incorporating surveyed instrument height and water-surface elevation. The development of the corrected water-surface elevations allows continuity with highresolution LiDAR terrain data set and bathymetric data. Due to environmental circumstances beyond our control and staggered installation of the pressure sensors, all data were not available through the same time periods (see Table A.1), and therefore to capture similarities and differences between sites, modeling was conducted on a common time period that includes the spring salmonid out-migration for the period February 1 through June 30, 2008, a time period of 75 days. While this study specifically uses in situ pressure sensor data, water-level measurements can also be derived by other means, such as a hydrodynamic model or developed "what-if?" scenarios. Figure A.3 shows hourly flows for each of the sites in the period between February 1 through June 30, 2008. 

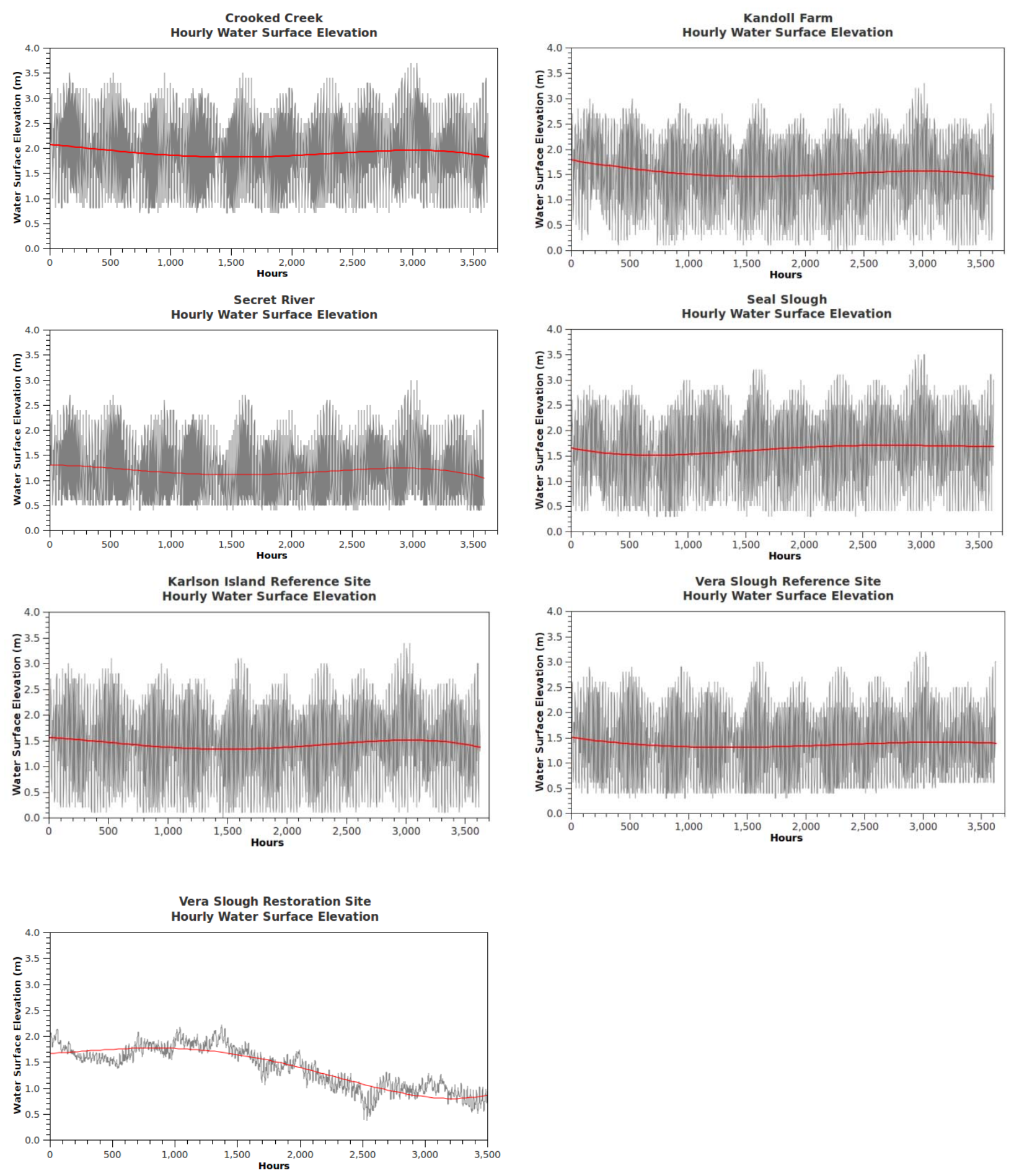

Figure A.3. Hourly Flows As Recorded by in-Situ Pressure-Sensors for Each of the Sites for the Period Between February 1 through June 30, 2008. A 4th order polynomial fit was applied to each of the data sets to visualize general trends at each site for the juvenile salmonids outmigration season. 


\section{A.4.2 Terrain Processing}

Using high-resolution elevation data, such as LiDAR data, of the ground surface and specialized terrain processing methods, it is possible to extract a fine level of detail of the terrain surface. The fine detail of the land surface, or microtopography, allows for a high-resolution horizontal and vertical determination of inundation areas. To gain the highest value from this type of processing, terrain collections should be completed under low water conditions (thus exposing a greater land surface area) or use a more non-standard LiDAR system such as the U.S. Army Corps of Engineers' Joint Airborne LiDAR Bathymetry Technical Center of Expertise Compact Hydrographic Airborne Rapid Total Survey system, which is capable collecting both terrestrial and bathymetric data.

Microtopographic terrain processing for all seven sites in the LCRE were generated using highresolution, last-return (i.e., ground/bare-earth surface) terrestrial LiDAR terrain data collected in January and February 2005 where leaf-off and dormant vegetation conditions were present. The LiDAR data were collected using a $40-\mathrm{kHz}$ airborne laser terrain mapping system at a flying height of 3500 feet, and for our study sites of interest, accuracies were reported at $\pm 15 \mathrm{~cm}-25 \mathrm{~cm}$ (PSLC 2005). The LiDAR point-cloud data are represented on a highly irregular pattern with an average spacing of $1.5 \mathrm{~m}$. To manage the large LiDAR data set, which covers the terrestrial floodplain areas of the LCRE from the river mouth upstream to Bonneville Dam (rkm 235) and consists of approximately 26 billion elevation postings, these data were imported to a spatially enabled open-source database (PostGIS/PostGreSQL), allowing the use of the Structured Query Language (SQL) queries to retrieve data defined by userprovided spatial extents. The LiDAR data for each site were initially queried and processed for a large extent around the site of interest, aided by the use of high-resolution imagery, high-order hydrologic unit code boundaries and any available hydrography data, to ensure sites were fully captured. Where possible, bathymetry data were also used and merged into the LiDAR data to make a continuous surface, thereby including areas under water at the time of the LiDAR collection and extending the area of coverage.

Where appropriate, the X,Y,Z triplets of the LiDAR and bathymetric data were used to process a 1-m continuous raster-based terrain surface using a state-of-the-art finite difference, locally adaptive, terrain algorithm (Hutchinson 1988, 1989, 1996, 2000; Hutchinson et al. 2009). The finite difference algorithm is highly effective for processing multi-scaled complex and subtle terrain while preserving hydrologic integrity using terrain roughness penalties and several terrain curvature constraints to ensure drainage areas are connected and ridges are preserved. It has been found that through a combination of the highresolution terrain data and finite difference processing, the microtopography of the estuarine landscape can be revealed (Diefenderfer et al. 2008). Other commonly used terrain-generation methods such as nearest-neighbor, kriging, and triangulated irregular networks have a tendency to diminish the structure of the microtopography and do not enforce rules of hydrologic flow. A microtopographic surface can be used to extract a fine level of detail in inundation patterns as presented here, but can also reveal high resolution and complex channel hydrography, terrain roughness for evaluating restoration progress, valley bottom flatness index for estimating depositional areas, stream power index for estimation of erosional areas, compound topographic index/wetness for estimating soil moisture/saturation, horizontal and vertical distance to stream channels, and more.

In some cases, it was necessary to enforce channels into the terrain surface, such as in areas where a dike breach has occurred since the LiDAR data collection (2005), tide gates occur within a diked structure, culverts are placed through built-up roadways, or where a roadway bridge exists over unimpeded channels. While high-resolution LiDAR data effectively capture dikes, built-up roadways, 
and bridges and because the data are 2.5-dimensional in their structure, there is no means to represent open-space underneath/through these engineered structures (e.g., bridges, culverts, tide gates). For example, a bridge over a stream channel is captured at the high elevation of the bridge deck with no additional elevations captured underneath the bridge; so this terrain space is represented as a rectangular block with no representation of the river channel below. The end result of the hydrologically influenced terrain analysis is the bridge over the river is interpreted as a physical barrier (such as a dam structure) such that ponding takes place and hydrologic connectivity is severed.

The notion of surface reconditioning was implemented in this study to mathematically warp and trench specific areas (dike/road/bridge stream crossings) through the terrain barrier to allow reconnection of surface flow. This specific area of research has resulted in many different algorithms being developed over the past 2 decades (Hutchinson 1988, 1989; Hellweger 1996; Maidment 1996; Mizgallewicz and Maidment 1996; Saunders 1999; Renssen and Knoop 2000; Turcotte et al. 2001; Doll and Lehner 2002; Soille et al. 2003; Hutchinson et al. 2009). The approach taken in this study is unique compared to past studies in that the drainage enforced surface reconditioning was only implemented in limited areas where there was a specific need. Outside of the barriers, the high-resolution LiDAR data provided great detail in the surface and were better for the terrain algorithms to resolve the flow directly from the source data rather than to implement terrain enforcement.

One limitation in the surface reconditioning is that in the immediate areas where adjustments are made, slope values and all other slope-based data derivatives will exhibit error. This is primarily due to the fact that a streamline is being used to cut through the barrier, which creates a steep-sided canyon through the barrier. The resulting terrain with a cut through the barrier is different than what the terrain would be like if the bridge were not there. However, the objective in this study was to look at the larger terrain surface and ensure hydrologic connectivity was in place, so the stated limitation, in this case is not of concern. An example of the resulting surface reconditioning is shown in Figure A.4.

\section{A.4.3 Terrain Analysis}

Raster-based flow accumulation and direction were extracted using the deterministic infinity ( $\mathrm{\infty} \infty$ ) method (Tarboton 1997) to generate flow direction, flow accumulation, and flow paths on the terrain surface. The flow direction uses every cell in the terrain set and sets a direction to flow to the next downstream cell. Through this directional process, an accumulation data set is generated keeping a cumulative total, in a spatial manner, of all the upstream cells that flow into it. The accumulation data define areas where overland flow begins to converge, leading to the generation of concentrated flow that leads to micro-channel flow and scaling to streams and rivers. The D $\infty$ method is an advanced method for extracting flow direction, flow accumulation, and flow paths on a continuous terrain surface. The traditional, and somewhat simplified approach for producing flow direction, flow accumulation, and flow paths is to use the deterministic-8 (D8) method (O'Callaghan and Mark 1984), which routes flow in one of eight directions separated by $45^{\circ}$ angles in the elevation data cell space. While the D8 method is able to achieve good results in areas with well-defined topography and coarser resolution terrain data, the highly subtle topography and complex channel network found in the LCRE requires a more sensitive and finer-detail approach. Because of the abundant presence of small micro-channel networks in the system, it is especially critical to use a method that is sensitive to minor drops in channel slope and orienting the channels properly to provide continuous flow through a drainage area. The Do method identifies an elevation cell center and divides the cell into eight planar triangular facets in which each facet is used to 
determine the slope of steepest descent in a 3 x 3 kernel window. This method avoids and/or minimizes flow dispersion, minimizes grid bias, and keeps a high precision of flow direction (Tarboton 1997).

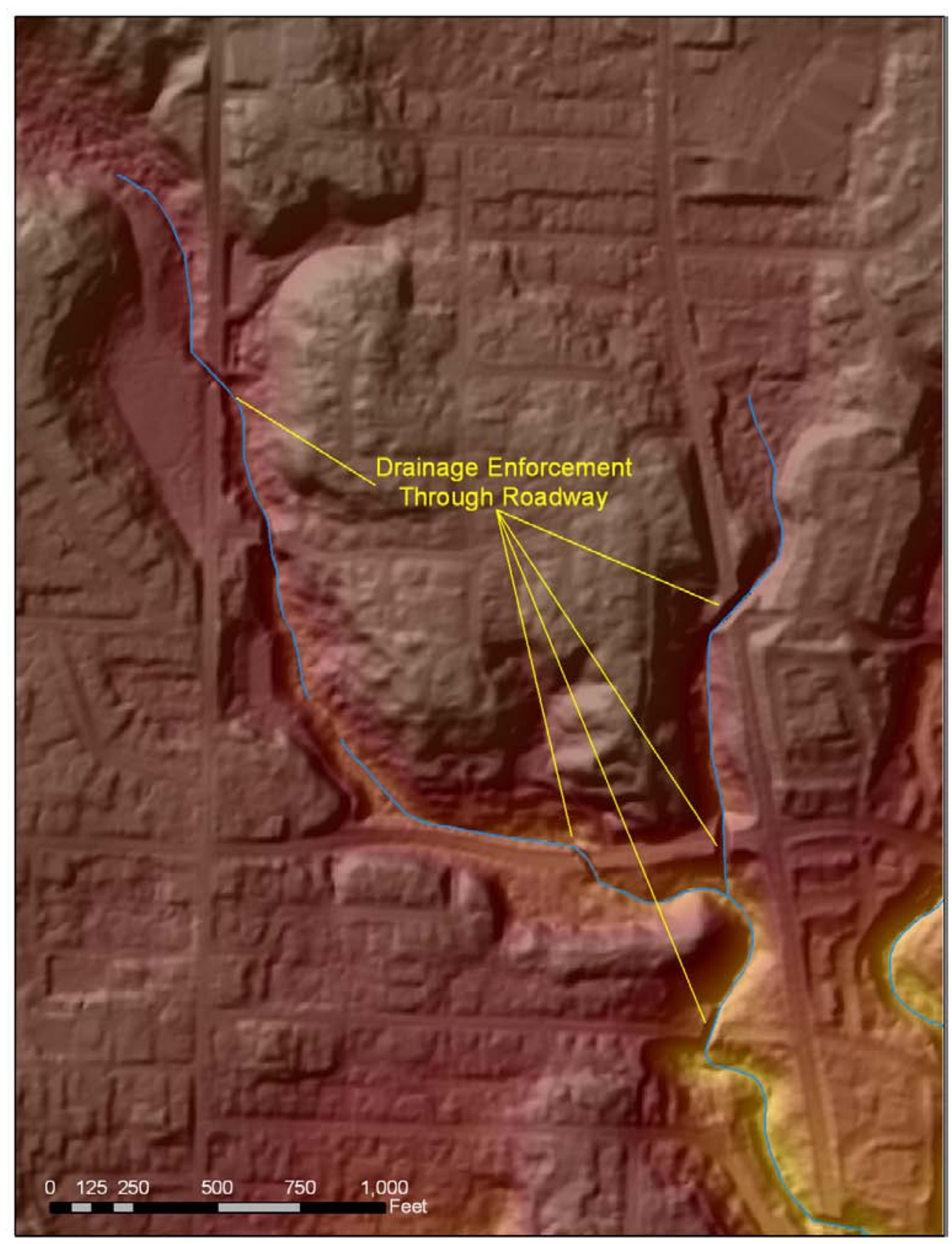

Figure A.4. Resulting Terrain Model After the Surface Conditioning Algorithm Was Run, Which Effectively Dissolved the Artificial Terrain Barriers Around Dike/Road/Bridge Stream Crossings

Using the flow accumulation data, the cell with the highest concentration value nearest to the location of the site outlet as it connects to the main stem river is used to extract the upslope contributing area or watershed boundary for the site of interest. In the case of one of the seven study sites, the Vera Slough reference site, there are a total of 18 sub-basins that drain directly to Youngs Bay; as a result, the model codes were updated to accommodate multiple basins that make up a single site. The defined watershed 
boundary is used to reduce the larger extent terrain data set to just that of the area that contributes flow to the site. Table A.2 provides calculated hydrologic contributing areas for each of the seven sites in this study.

\section{A.4.4 Inundation Modeling}

The method presented in this paper demonstrates a simple terrain-based inundation model that develops a spatiotemporal relationship between water-surface elevation data over time and detailed terrain data to extract areas and, if useful, to rapidly assess a site. The areas of inundation corresponding to water-surface elevations are determined using a GIS-based terrain extraction and a channel connectivity algorithm, that uses a kernel point at the basin outlet, extracts associated water-surface elevation and area, then progressively calculates area-elevations at 10 -cm increments. The water-surface elevation increment level is user-specified and the value of $10-\mathrm{cm}$ was used to represent the minimum water depth that could be used by out-migrating salmonids. The resulting spatial analysis provides an area-elevation lookup table after which the 1.0-hr time steps of the water-level sensor data for the period of record can be related. The relation is performed by generating frequencies of the water-level data binned into $10-\mathrm{cm}$ increments, after which the total occurrences for each water-level bin are assigned to the total inundation area at each level, thereby generating a metric of hectare-hours of inundation at each water level as well as for a site total for the time period.

Using the graph relationship between water-surface elevation and area, the point of inflection is automatically determined from the data series and indicates the bankfull elevation and hence the beginning of floodplain inundation. The model uses an algorithm that implements a moving window across the data series. The algorithm first calculates the mean slope within the window, then uses the mean slope values from each window and determines the first greatest change in slope, and finally, calculates slope between the individual points in the selected window and selects the point prior to the greatest change in slope as the bankfull elevation. The methods of Gippel and Stewardson (1998) including maximum curvature and slope were evaluated; however, the algorithm developed as part of this model appears to more closely represent what is determined manually from a graph. Using the inflection point value, or bankfull elevation, the model segments the hectare-hours of inundation into above and below the bankfull elevation giving indication as to the condition of the site. For example, restoration sites are likely to be inundated more frequently than the natural reference sites.

The area-time inundation index is calculated as the number of hectare-hours of inundation, including both in-channel and floodplain area, summed at 10 -cm increments and divided by the total possible hectare-hours for each site. The total possible hectare-hours are determined using the total area of the site and consider a full inundation for the time period of interest. This provides a theoretical maximum on which to base the area-time inundation index and importantly, provides a metric that can be used to compare individual sites. Numeric results of the modeling for the seven sites can be found in Table A.2, water-surface area-elevation relationships in Figure A.5, total hectare-hours of inundation curves in Figure A.6, and spatial plots of water-surface elevation over area in Figure A.7 - A.13. 
Table A.2. All Calculations Performed as a Part of the Time-Area Inundation Index Model Are Presented for All Seven Sites

\begin{tabular}{|c|c|c|c|c|c|c|c|}
\hline & CC & $\mathrm{KF}[\mathrm{R}]$ & KI & SS & SR & VS & $\mathrm{VS}[\mathrm{R}]$ \\
\hline Time Steps (hr) & 3625 & 3612 & 3624 & 3625 & 3593 & 3623 & 3623 \\
\hline Total Area (ha) & 77.62 & 65.60 & 15.03 & 7.85 & 50.03 & 4.62 & 106.03 \\
\hline Bankfull Elevation (m) & 2.7 & 1.6 & 2.6 & 2.5 & 2.5 & 1.9 & 1.6 \\
\hline $\begin{array}{l}\text { \% Time of Overbank } \\
\text { Inundation }\end{array}$ & 18.73 & 52.07 & 6.82 & 14.78 & 1.84 & 28.67 & 36.12 \\
\hline Total Hectare-Hours & 9629 & 32668 & 913 & 1230 & 1580 & 1075 & 2659 \\
\hline Hectare-Hours $\geq$ Bankfull & $\begin{array}{c}8064 \\
(83.75 \%)\end{array}$ & $\begin{array}{c}32149 \\
(98.41 \%)\end{array}$ & $\begin{array}{c}607 \\
(66.48 \%)\end{array}$ & $\begin{array}{c}745 \\
(60.53 \%)\end{array}$ & $\begin{array}{c}228 \\
(14.41 \%)\end{array}$ & $\begin{array}{c}965 \\
(89.72 \%)\end{array}$ & $\begin{array}{c}1712 \\
(64.37 \%)\end{array}$ \\
\hline Hectare Hours < Bankfull & $\begin{array}{c}1565 \\
(16.25 \%)\end{array}$ & $\begin{array}{c}519 \\
(1.59 \%)\end{array}$ & $\begin{array}{c}306 \\
(33.51 \%)\end{array}$ & $\begin{array}{c}486 \\
(39.46 \%)\end{array}$ & $\begin{array}{c}1352 \\
(85.59 \%)\end{array}$ & $\begin{array}{c}110 \\
(10.27 \%)\end{array}$ & $\begin{array}{c}947 \\
(35.63 \%)\end{array}$ \\
\hline $\begin{array}{l}\text { Max. Possible Hectare } \\
\text { Hour Inundation }\end{array}$ & 140680 & 118473 & 27232 & 14219 & 89873 & 8384 & 192132 \\
\hline Area-Time Index & 5.73 & 27.14 & 2.23 & 5.24 & 0.25 & 11.5 & 0.89 \\
\hline
\end{tabular}



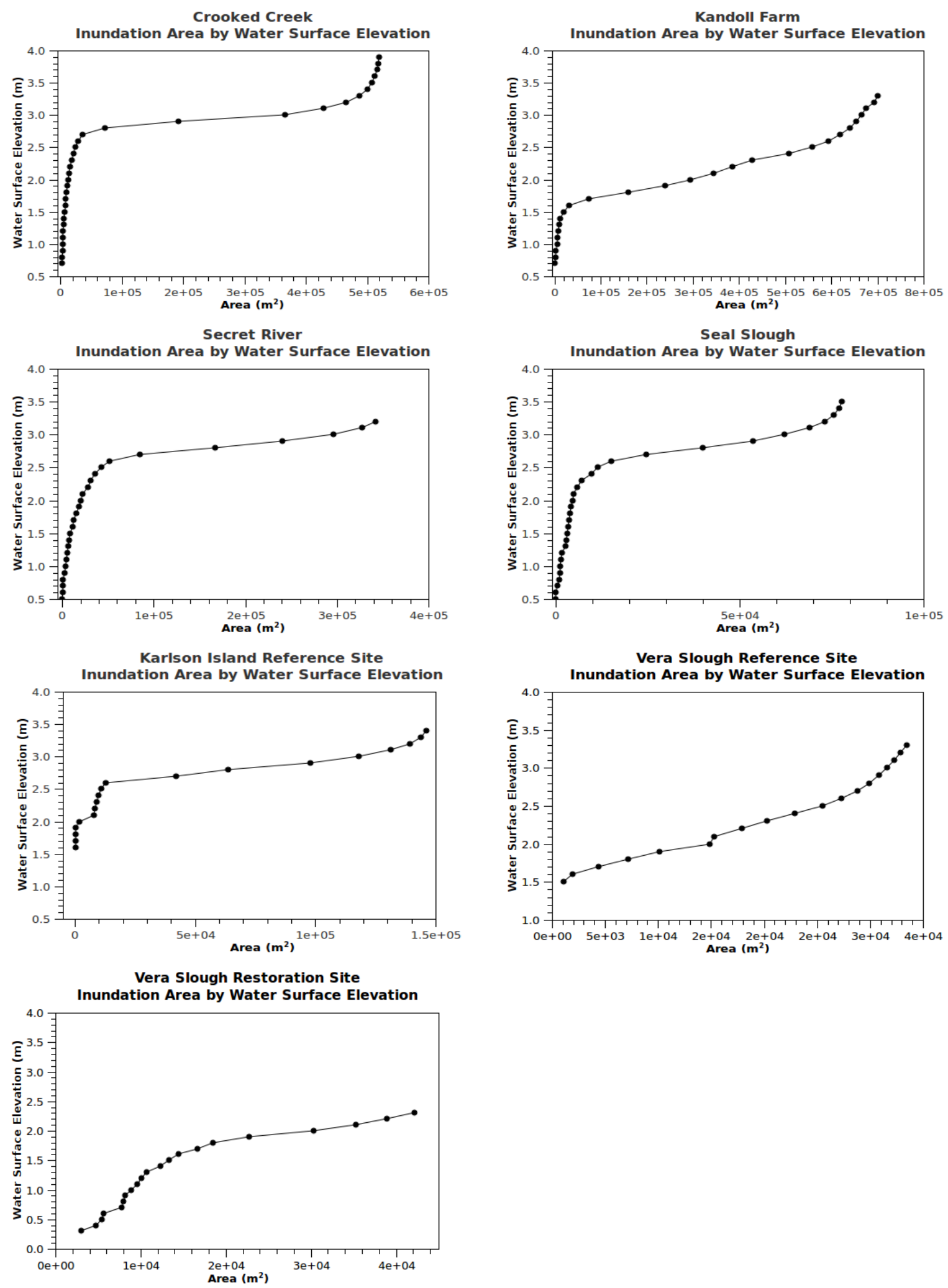

Figure A.5. Water-Surface Elevation-Area Relationships Established for Each Site. Note for many of the sites, a clear inflection point marking the overbank elevation. 

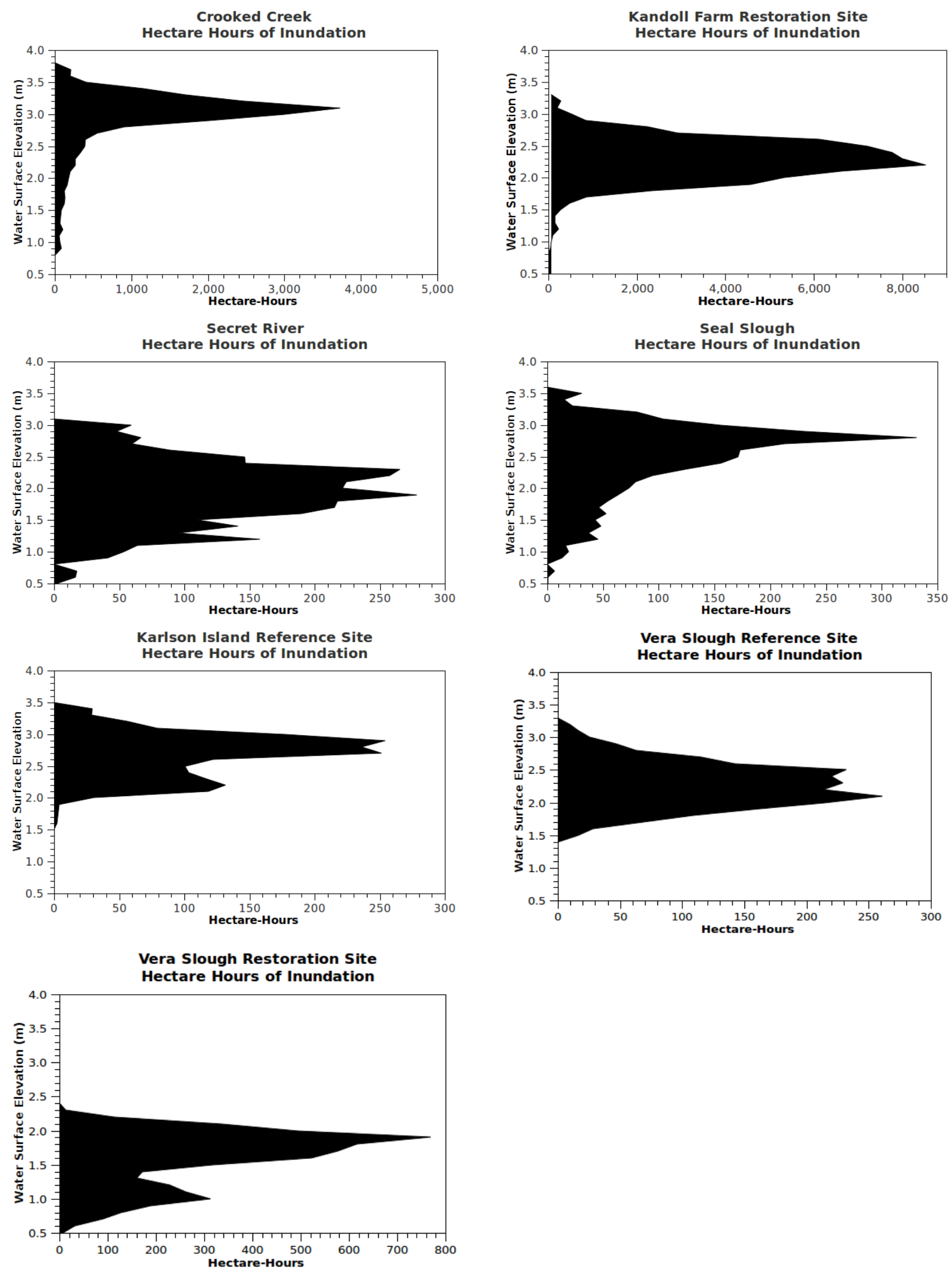

Figure A.6. Total Hectare-Hours of Inundation by Water-Surface Elevation for Each of the Seven Sites 

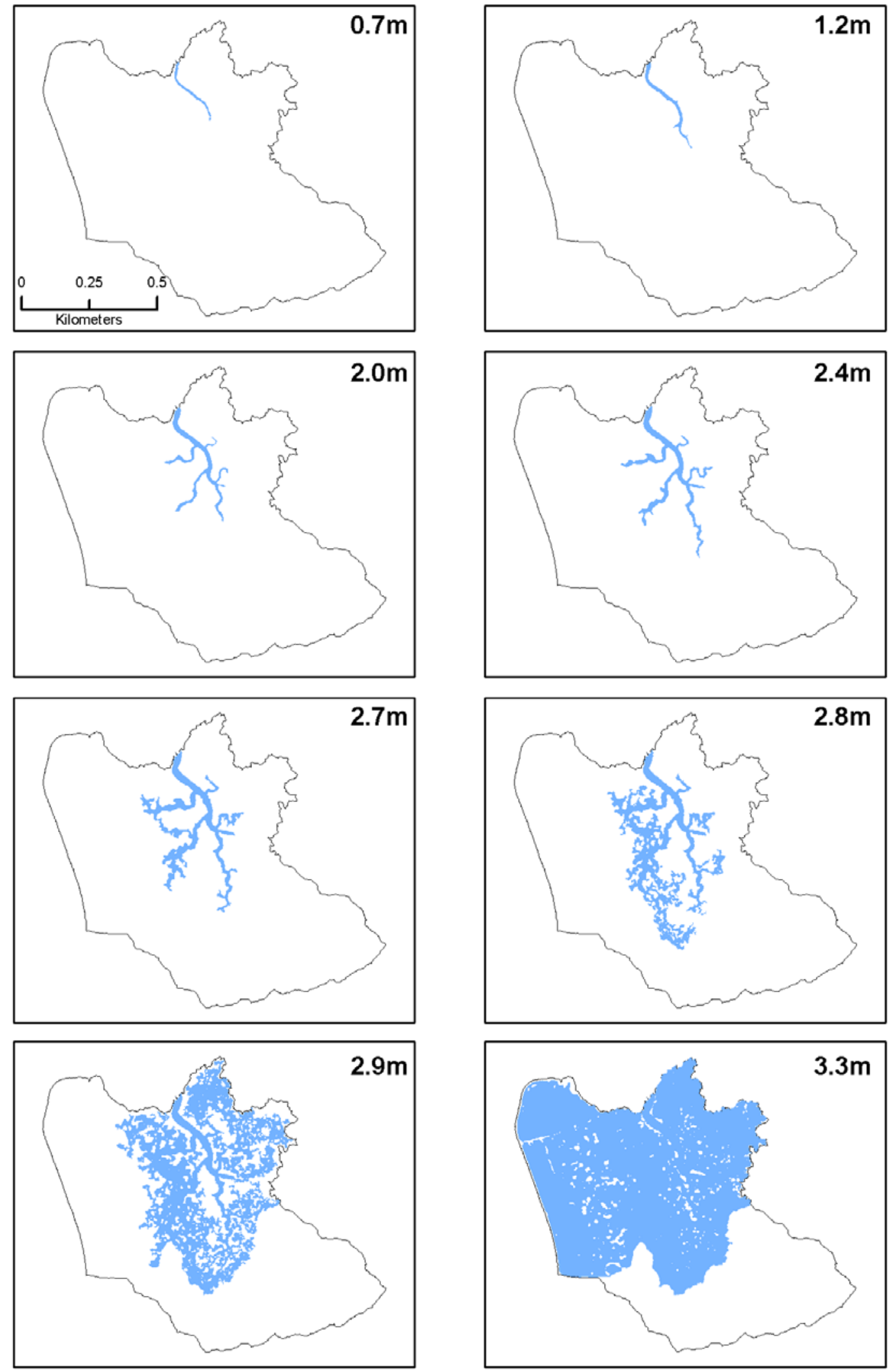

Figure A.7. Inundation Areas at Multiple Water-Surface Elevations for Crooked Creek 

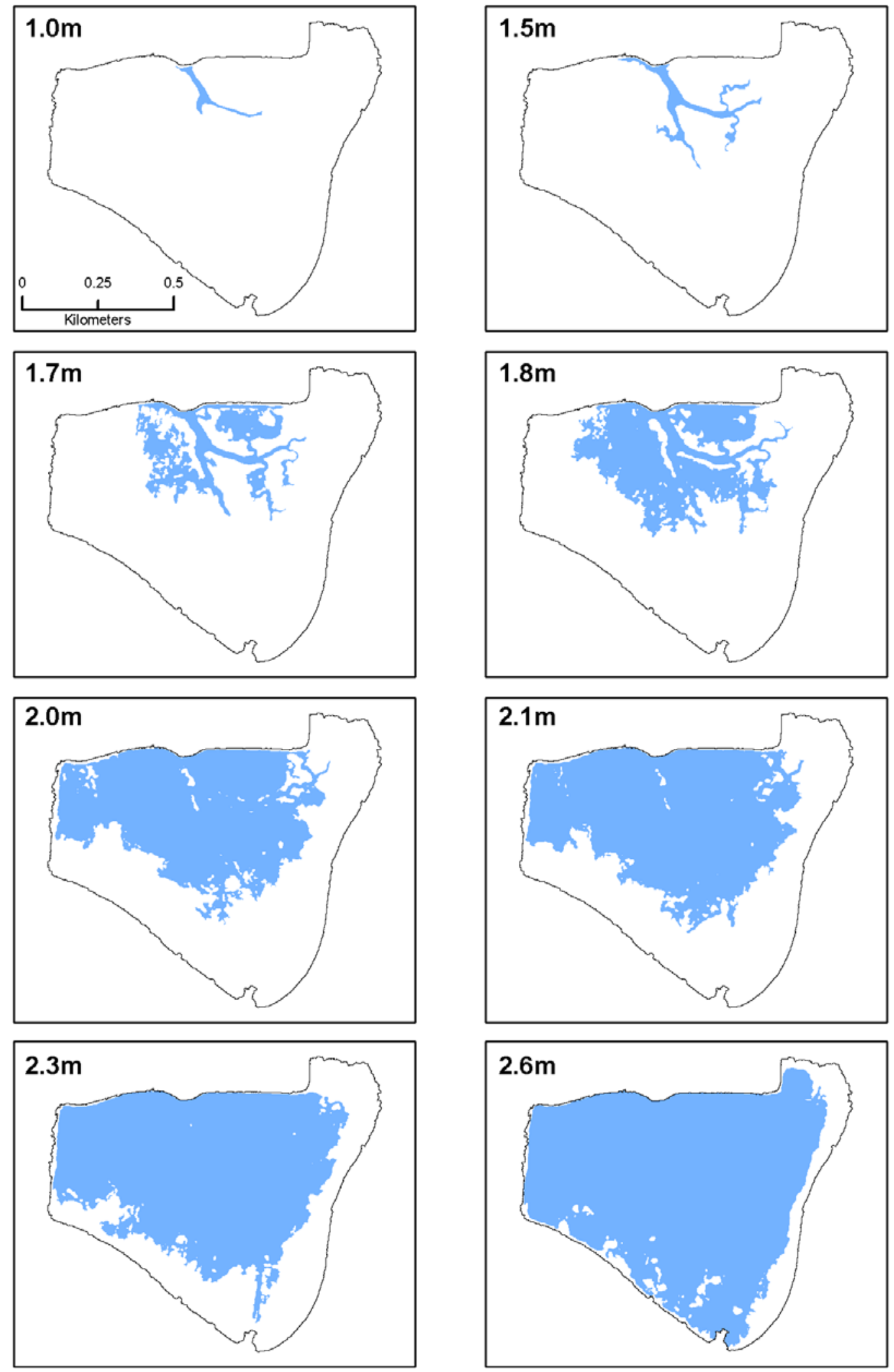

Figure A.8. Inundation Areas at Multiple Water-Surface Elevations for Kandoll Farm 

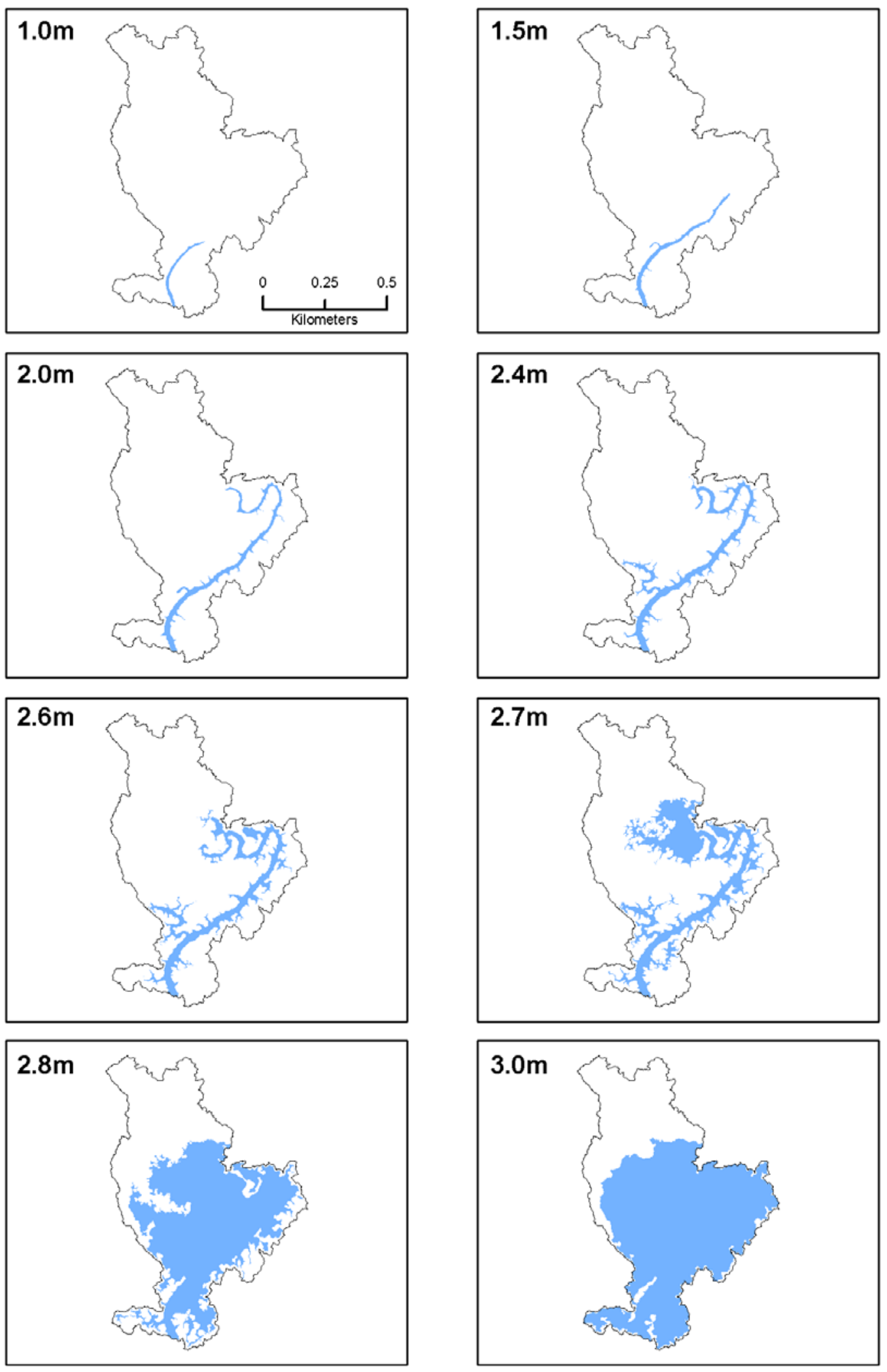

Figure A.9. Inundation Areas at Multiple Water-Surface Elevations for Secret River 

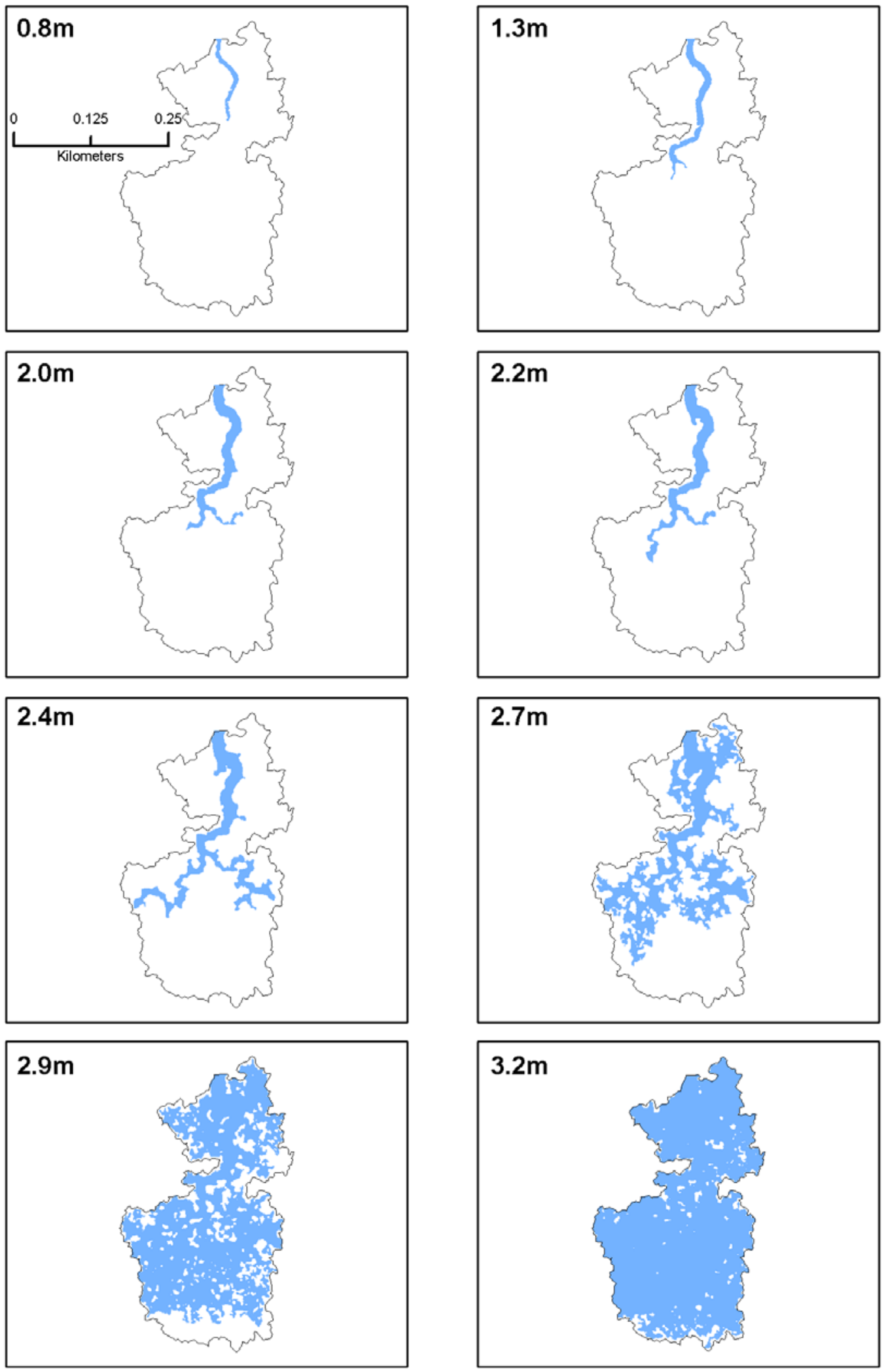

Figure A.10. Inundation Areas at Multiple Water-Surface Elevations for Seal Slough 

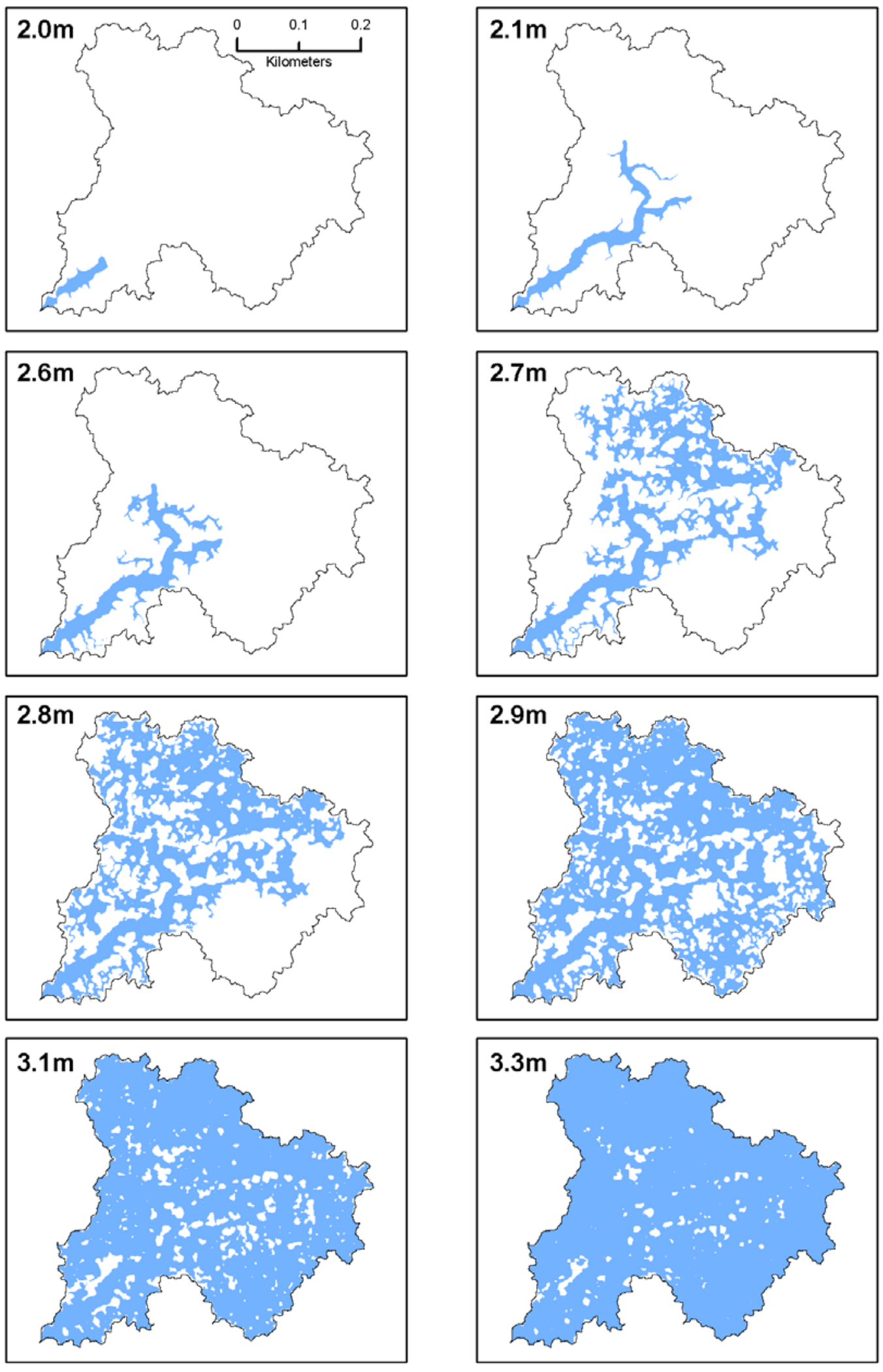

Figure A.11. Inundation Areas at Multiple Water-Surface Elevations for Karlson Island 

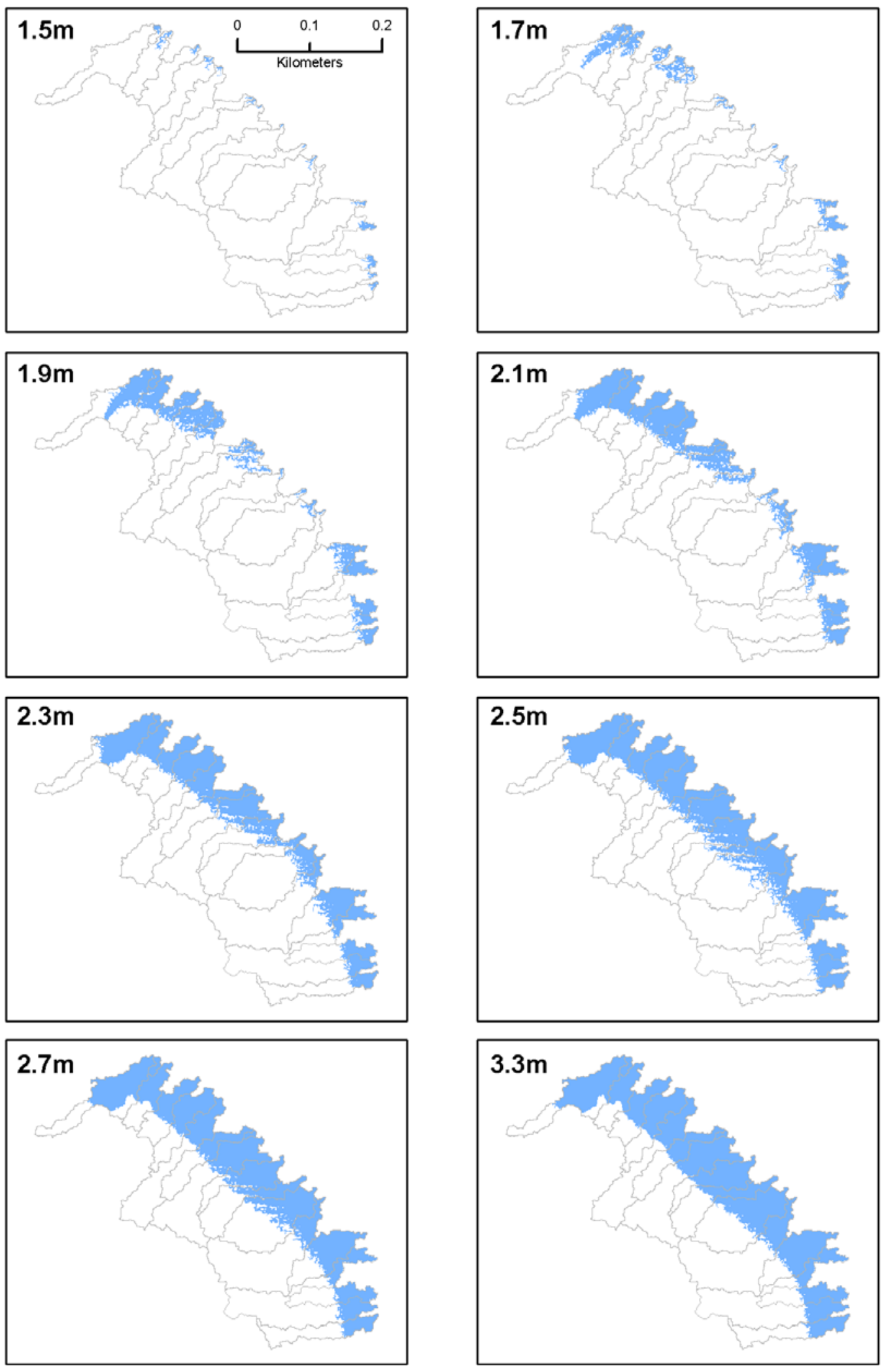

Figure A.12. Inundation Areas at Multiple Water-Surface Elevations for the Vera Slough Reference Site 

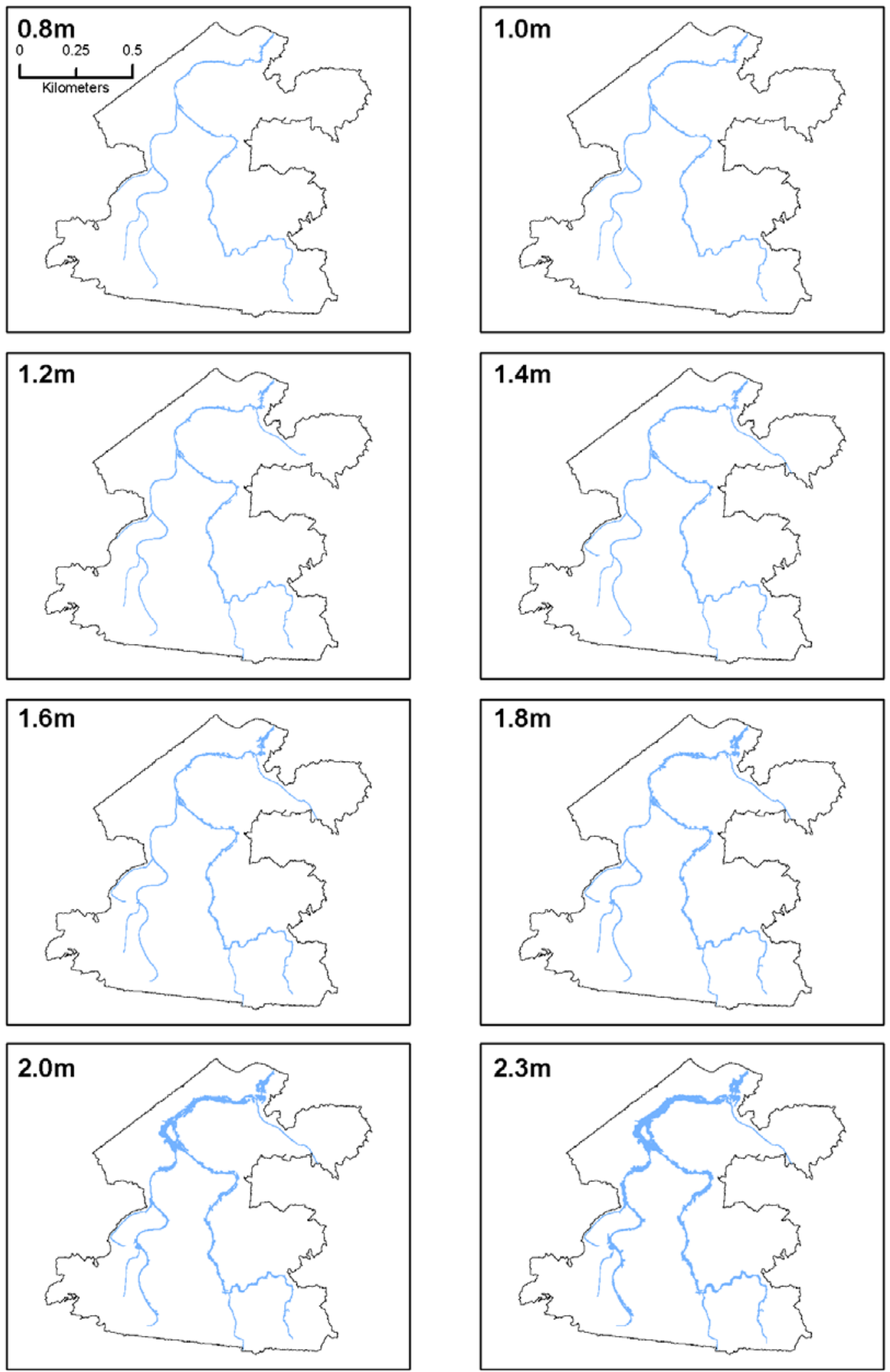

Figure A.13. Inundation Areas at Multiple Water-Surface Elevations for the Vera Slough Restoration Site 


\section{A.5 Discussion}

A variety of quantitative approaches have been produced in response to the need to selectively prioritize societal investments in ecological restoration, which are necessarily limited by economic factors. These approaches have been variously tailored to focal species (Thompson et al. 2006), and to ecosystems including riparian zones (Russell et al. 1997; Timm et al. 2004), wetlands (Kunert 2005; Lin et al. 2006), and coastal shorelines (Diefenderfer et al. 2009). The goal of a restoration program is to guide the prioritization process, and for the LCRE the primary goal of the ecosystem restoration program is to recover 13 "evolutionarily significant units" (Waples 1991) of salmonids (NMFS 2008). The use of estuarine and tidal freshwater habitats is typical of many juvenile salmonids migrating from large rivers on the West Coast of North America (Levy and Northcote 1982; Levings et al. 1991; Levings 1994), but like most large rivers of the world the Columbia River has been largely hydrologically severed from its floodplain by flow regulation and diking (Tockner and Stanford 2002; Kukulka and Jay 2003).

Therefore, the large-scale prioritization of floodplain sites for hydrological reconnection restoration actions that has been recommended (Opperman et al. 2009) centers on the analysis of the potential sitescale hydrologic regime relative to existing flow management of the main stem river and other flood controls that prevent lateral connectivity. The hydrologic regime and topography/bathymetry of a site will govern both habitat accessibility by juvenile salmonids (Simenstad and Cordell 2000) and the ability of the reconnected wetland ecosystem to subsidize the food web of the main stem river (Polis et al. 1997).

Using the methods described herein, functional wetted area can be modeled prior to consideration for restoration, as a screening tool to help understand the potential outcomes of a suite of possible projects, without investment in the costly development of site-scale two- or three-dimensional hydrodynamic models. Furthermore, if a one-dimensional landscape-scale hydrodynamic model is available, the time required to collect site-specific water-level data will be unnecessary, because synthetic water-elevation patterns for proposed restoration sites could be derived from the model and verified with data from nearby sites. Additional consideration for the developed methods can aid in the development of multi-objective optimized flows coming from upstream dams. Through the development of characteristic sites throughout the LCRE, various flow patterns released at Bonneville Dam can be tested for optimization of accessible habitat and flow for out-migrating salmonids. The ideal optimization patterns can be integrated into other optimization objectives at Bonneville Dam including power generation, navigation, flood control, accessible habitat, etc.

While we have developed and demonstrated this model on a limited set of restoration and reference sites in the lower part of the LCRE, there is a transition from tidal dominated fluctuations to hydro system dominated fluctuations over the longitudinal gradient of the river from the mouth to Bonneville Dam (Chawla et al. 2008), and the utility of the method remains to be demonstrated on upriver sites. Furthermore, from the salmon recovery perspective, there is a need to define representative flows at the Dam (e.g., low, medium, high) and stratify the effects on downriver shallow water habitats relative to important annual migration periods and the potential effects of climate change (Mote et al. 2005; Battin et al. 2007). 


\section{A.6 References}

Battin, J, MW Wiley, MH Ruckelshaus, RN Palmer, E Korb, KK Bartz, and H Imaki. 2007. “Projected Impacts of Climate Change on Salmon Habitat Restoration.” PNAS 104(16):6720-6725.

Bernhardt, ES, EB Sudduth, MA Palmer, JD Allan, JL Meyer, G Alexander, J Follstad-Shah, B Hasssett, R Jenkinson, R Lave, J Rumps, and L Pagano. 2007. "Restoring Rivers One Reach at a Time: Results from a Survey of U.S. River Restoration Practitioners." Restoration Ecology 15:482-93.

Bottom, D, CA Simenstad, J Burke, AM Baptista, DA Jay, KK Jones, E Casillas, and MH Schiewe. 2005. Salmon at River's End: The Role of the Estuary in the Decline and Recovery of Columbia River Salmon. U.S. Department of Commerce, National Oceanic and Atmospheric Administration (NOAA) Technical Memorandum NMFS-NWFSC-68, 246 p.

Bunn, S, and A Arthington. 2002. "Basic Principles and Ecological Consequences of Altered Flow Regimes for Aquatic Biodiversity.” Environmental Management 30:492-507.

Callaway, JC, G Sullivan, JS Desmond, GD Williams, and JB Zedler. 2001. “Assessment and Monitoring.” In: Handbook for Restoring Tidal Wetlands, ed. JB Zedler. CRC Press, Boca Raton, Florida.

Chawla, A, DA Jay, AM Baptista, M Wilkin, and C Seaton. 2008. "Seasonal Variability and EstuaryShelf Interactions in Circulation Dynamics of a River-Dominated Estuary.” Estuaries and Coasts 31:269-288.

De Steven, D, and MM Toner. 2004. "Vegetation of Upper Coastal Plain Depression Wetlands: Environmental Templates and Wetland Dynamics Within a Landscape Framework.” Wetlands 24:23-42.

Diefenderfer HL, AM Coleman, AB Borde, and IA Sinks. 2008. "Hydraulic Geometry and Microtopography of Tidal Freshwater Forested Wetlands and Implications for Restoration, Columbia River, U.S.A.” Ecohydrology and Hydrobiology 8(2-4):339-361. doi: 10.2478/v10104-009-0027-7

Diefenderfer, HL, KL Sobocinski, RM Thom, CW May, AB Borde, SL Southard, J Vavrinec, and NK Sather. 2009. "Multiscale Analysis of Restoration Priorities for Marine Shoreline Planning.” Environmental Management 44:712-731.

Doll, Pand B Lehner. 2002. “Validation of a New Global 30-Min Drainage Direction Map.” Journal of Hydrology 258(1-4):214-231.

Dynesius, M and C Nilsson. 1994. "Fragmentation and Flow Regulation of River Systems in the Northern Third of the World.” Science 266(5186):753-762.

Ehrenfeld, JG, H Bowman Cutway, R Hamilton IV, and E Stander. 2003. "Hydrologic Description of Forested Wetlands in Northeastern New Jersey, USA-An Urban/Suburban Region.” Wetlands 23:685-700. 
Florsheim, JL, JF Mount, and CR Constantine. 2006. “A Geomorphic Monitoring and Adaptive Assessment Framework to Assess the Effect of Lowland Floodplain River Restoration on ChannelFloodplain Sediment Continuity.” River Research and Applications 22:353-375.

Garcia-Berdeal, I, B Hickey, and M Krause. 2002. "Influence of wind stress and ambient flow on a high discharge river plume.” Journal of Geophysical Research 107:3130.

Gippell, CJ and MJ Stewardson. 1998. "Use of Wetted Perimeter in Defining Minimum Environmental Flows.” Regulated Rivers: Research \& Management 14:53-67.

Hellweger, R. 1996. “AGREE - DEM Surface Reconditioning System.” Center for Research in Water Resources, The University of Texas at Austin, Austin, Texas. Available at http://www.ce.utexas.edu/prof/maidment/gishydro/ferdi/research/agree/agree.html

Hickey, B and N Banas. 2003. “Oceanography of the U.S. Pacific Northwest Coastal Ocean and Estuaries with Application to Coastal Oceanography.” Estuaries 26:1010-1031.

Hutchinson, MF. 1988. "Calculation of hydrologically sound digital elevation models.” In: Third International Symposium on Spatial Data Handling. International Geographical Union, Columbus, Ohio.

Hutchinson, MF. 1989. “A New Method for Gridding Elevation and Streamline Data with Automatic Removal of Pits.” Journal of Hydrology 106:211-232.

Hutchinson, MF. 1996. "A Locally Adaptive Approach to the Interpolation of Digital Elevation Models.” Third International Conference/Workshop on Integrating GIS and Environmental Modeling. National Center for Geographic Information and Analysis, University of California, Santa Barbara, California. Available at: http://www1.gsi.go.jp/geowww/globalmapgsi/gtopo30/papers/local.html.

Hutchinson, MF. 2000. "Optimising the degree of data smoothing for locally adaptive finite element bivariate smoothing splines.” ANZIAM Journal 42(E):C774-C796.

Hutchinson, MF, JA Stein, JL Stein, and T Xu. 2009. “Locally adaptive gridding of noisy high resolution topographic data.” In: Proceedings of the 18th World IMACS/MODSIM Congress, Cairns, Australia 13-17, July 2009, Elsevier B.V., Amsterdam, The Netherlands.

Johnson, GJ, HL Diefenderfer, BD Ebberts, C Tortorici, T Yerxa, J Leary, and JR Skalski. 2008. Research, Monitoring, and Evaluation for the Federal Columbia River Estuary Program. PNNL-17300, report prepared by the Pacific Northwest National Laboratory, Sequim, Washington, for the Bonneville Power Administration, Portland Oregon (January 31, 2008).

Junk, WJ. 1999. “The Flood Pulse Concept of Large Rivers: Learning from the Tropics.” Archiv fur Hydrobiologie 115:261-280.

Kukulka, T and DA Jay. 2003. "Impacts of Columbia River Discharge on Salmonid Habitat II: Changes in Shallow-Water Habitat.” Journal of Geophysical Research 108(C9):3294. 
Kunert, K. 2005. A GIS Approach to Habitat Restoration Site Selection and Prioritization in the New York-New Jersey Harbor Estuary. Master's thesis, Duke University, Durham, North Carolina.

Levings, CD, K Conlin, and B Raymond. 1991. "Intertidal Habitats Used by Juvenile Chinook Salmon (Oncorhynchus Tshawytscha) Rearing in the North Arm of the Fraser River Estuary.” Mar. Pollution Bull. 22:20-26.

Levings, CD and D. Bouillon. 1994. Estuarine and Ocean Survival of Northeastern Pacific Salmon. U.S. Department of Commerce, National Oceanic and Atmospheric Administration (NOAA) Technical Memorandum NOAA-NMFS-NWFSC TM-29.

Levy, DA and TG Northcote. 1982. "Juvenile Salmon Residency in a Marsh Area of the Fraser River Estuary.” Can. J. Fish. Aquat. Sci. 39:270-276.

Lin, JP, SG Bourne, and BA Kleiss. 2006. Creating a Wetland Restoration Decision Support System Using GIS Tools. Report No. ERDC TN-EMRRP-EM-05, U.S. Army Corps of Engineers, Engineer Research and Development Center, Vicksburg, Mississippi.

Maidment, D. 1996. “GIS and Hydrological Modelling: An Assessment of Progress.” In: Third International Conference on GIS and Environmental Modelling, Santa Fe, New Mexico, 20-25 January, 1996, National Center for Geographic Information and Analysis, University of California, Santa Barbara, California.

Mantua, N, I Tohver, and A Hamlet. 2009. "Impacts of Climate Change on Key Aspects of Freshwater Salmon Habitat in Washington State.” Chapter 6 in The Washington Climate Change Impacts Assessment: Evaluating Washington's Future in a Changing Climate, Climate Impacts Group, University of Washington, Seattle, Washington.

Meyer, CK, MR Whiles, and SG Baer. 2008. "Plant Community Recovery Following Restoration in Temporally Variable Riparian Wetlands.” Restoration Ecology 18:52-64.

Mizgallewicz, PJ and D Maidment. 1996. Modelling Agricultural Transport in Midwest Rivers Using Geographic Information Systems. Online Report 96-6, Centre for Research Water Resources, University of Texas, Austin, Texas.

Mote, PW, AF Hamlet, MP Clark, and DP Lettenmaier. 2005. “Declining Mountain Snowpack in Western North America.” Bulletin of the American Meteorological Society 86(1):39-49.

National Marine Fisheries Service (NMFS). 2008. Biological Opinion - Consultation on Remand for Operation of the Federal Columbia River Power System, 11 Bureau of Reclamation Projects in the Columbia Basin and ESA Section 10(a)(1)(A) Permit for Juvenile Fish Transportation Program. NMFS (National Oceanic and Atmospheric Administration Fisheries) - Northwest Region, Seattle, Washington.

Naiman, RJ, and H Décamps. 1997. “The Ecology of Interfaces: Riparian Zones.” Annual Review of Ecology and Systematics 28:621-58. 
Neal, VT. 1972. "Physical Aspects of the Columbia River and Its Estuary.” In: The Columbia River Estuary and Adjacent Ocean Waters: Bioenvironmental Studies. Eds. AT Pruter and DL Alverson. University of Washington Press, Seattle, Washington.

O’Callaghan, JF and DM Mark. 1984. “The Extraction of Drainage Networks from Digital Elevation Data.” Comput. Vision Graphics Image Process 28:328-344.

Opperman, JJ, GE Galloway, J Fargione, JF Mount, BD Richter, and S Secchi. 2009. "Sustainable Floodplains Through Large-Scale Reconnection to Rivers.” Science 326:1487-1488.

PSLC. 2005. Lower Columbia River 2005 LiDAR, Final Report. Puget Sound LiDAR Consortium, Seattle, Washington

Poff, NL, JD Allan, MB Bain, JR Karr, KL Prestergaard, BD Richter, RE Sparks, and JC Stromberg. 1997. “The Natural Flow Regime: A Paradigm for River Conservation and Restoration.” BioScience 47:769-784.

Polis, GA, WB Anderson, and RD Holt. 1997. “Toward an Integration of Landscape and Food Web Ecology: The Dynamics of Spatially Subsidized Food Webs.” Annual Review of Ecology and Systematics 18:289-316.

Qian Y, WI Gustasfson, LR Leung, and SJ Ghan. 2009. “Effects of Soot-Induced Albedo Change on Snowpack and Hydrological Cycle in Western United States Based on Weather Research Forecasting Chemistry and Regional Climate Simulations.” Journal of Geophysical Research-Atmospheres 114, D03108, doi:10.1029/2008JD011039.

Renssen, H and JM Knoop. 2000. “A Global River Routing Network for Use in Hydrological Modeling.” Journal of Hydrology 230 (3-4):230-243.

Russell, GD, CP Hawkins, and MP O’Neill. 1997. "The Role of GIS in Selecting Sites for Riparian Restoration Based on Hydrology and Land Use.” Restoration Ecology 5:56-68.

Saunders, W. 1999. “Preparation of DEMs for Use in Environmental Modelling Analysis.” 1999 ESRI User Conference, ESRI Online, San Diego, California.

Sherwood, CR and JS Creager. 1990. "Sedimentary Geology of the Columbia River Estuary.” Progress in Oceanography 25:15-79.

Sherwood, CR, DA Jay, RB Harvey, P Hamilton, and CA Simenstad. 1990. "Historical Changes in the Columbia River Estuary.” Progress in Oceanography 25:299-352.

Siebentritt, MA, GG Ganf, and KF Walker. 2004. "Effects of an Enhanced Flood on Riparian Plants of the River Murray, South Australia.” River Research and Applications 20:765-774.

Silvestri, S, A Defina, and M Marani. 2004. “Tidal Regime, Salinity and Salt Marsh Plant Zonation.” Estuarine, Coastal and Shelf Science 62:119-130. 
Simenstad, CA and JR Cordell. 2000. "Ecological Assessment Criteria for Restoring Anadromous Salmonid Habitat in Pacific Northwest Estuaries.” Ecological Engineering 15:283-302.

Soille, P, JV Vogt, and R Colombo. 2003. “Carving and Adaptive Drainage Enforcement of Grid Digital Elevation Models.” Water Resources Research 39(12):1366-1379.

Tarboton, DG. 1997. “A New Method for the Determination of Flow Directions and Contributing Areas in Grid Digital Elevation Models.” Water Resources Research 33(2):309-319.

Thomas, DW. 1983. Changes in the Columbia River Estuary Habitat Types Over the Past Century. Columbia River Estuary Data Development Program 51. (Available from Columbia River Estuary Study Taskforce, Box 175, Astoria, Oregon 97103.)

Thompson, L, F vanManen, S Shlarbaum, and M DePoy. 2006. “A Spatial Modeling Approach to Identify Potential Butternut Restoration Sites in Mammoth Cave National Park.” Restoration Ecology 14:289-296.

Timm, RK, RC Wissmar, JW Small, TM Leschine, and G Lucchetti. 2004. “A Screening Procedure for Prioritizing Riparian Management.” Environmental Management 33:151-161.

Tockner K and JA Stanford. 2002. "Riverine Flood Plains: Present State and Future Trends.” Environmental Conservation 29:308-330.

Toth, LA. 1995. "Principles and Guidelines for Restoration of River/Floodplain Ecosystems Kissimmee River, Florida.” In Rehabilitating Damaged Ecosystems. Ed. J Cairns, Jr. Lewis Publishers, Boca Raton, pp. 49-73.

Turcotte, R, JP Fortin, AN Rousseau, S Massicotte, and JP Villeneuve. 2001. "Determination of the Drainage Structure of a Watershed Using a Digital Elevation Model and a Digital River and Lake Network.” Journal of Hydrology 240(3-4):225-242.

Waples, RS. 1991. "Pacific Salmon, Oncorhynchus Spp., and the Definition of "Species" Under the Endangered Species Act.” U.S. Natl. Mar. Fish. Serv., Mar. Fish. Rev. 53(3):11-22.

Welcomme, RL. 1979. Fisheries Ecology of Floodplain Rivers. Longman, London.

Welcomme, RL. 2008. “World Prospects for Floodplain Fisheries.” Ecohydrology and Hydrobiology 8:169-182.

White, PS and STA Pickett. 1985. "Natural Disturbance and Patch Dynamics: An Introduction.” Pages 3-13 in The Ecology of Natural Disturbance and Patch Dynamics. Eds. STA Pickett and PS White. Academic Press, San Diego. 



\section{Appendix B}

\section{Wetland Vegetation Community Distribution and Inundation Patterns in the Tidally Influenced Columbia River, USA}





\title{
Appendix B - Wetland Vegetation Community Distribution and Inundation Patterns in the Tidally Influenced Columbia River, USA
}

\author{
Prepared by Amy B. Borde, Heida L. Diefenderfer, Shon A. Zimmerman, and Ronald M. Thom
}

\section{B.1 Abstract}

Our research quantifies the hydrologic conditions necessary for development of brackish and tidal freshwater wetland plant communities and the distribution of plant communities relative to previously existing ecosystem classification systems for the lower Columbia River and estuary (LCRE). We have collected vegetation cover, elevation, and hydrology data from 40 reference condition wetland sites within the floodplain of the 235-km tidally influenced Columbia River. These previously limited data are required to understand the distribution of wetland community types in a regulated river system with complex tidal and flow-dominated hydrologic processes. Analyses include ordination of species richness relative to spatial variation of physical controlling factors, cluster analysis of community types, and the magnitude, timing, and duration of surface-water inundation within and between communities and/or sites. Preliminary results indicate species richness varies with controlling factors along a longitudinal gradient, community type varies on elevational gradients, and specific inundation patterns are strongly correlated with community types. Some invasive species have wide elevation ranges and inundation tolerances lending to their competitive ability. This information fundamentally informs restoration design, restoration project effectiveness monitoring, and invasive species management.

\section{B.2 Introduction}

The loss of biodiversity in fresh waters of the world far exceeds terrestrial losses (Dudgeon et al. 2006), and fragmentation and flow regulation have affected the total water discharge of many large rivers of the world (Dynesius and Nilsson 1994). Numerous restoration projects have been initiated to attempt to maintain and recover these valuable resources (Bernhardt et al. 2005). Nevertheless, identifying suitable reference conditions for river floodplain restoration remains a challenge for the young sciences of restoration ecology and the ecology of running waters (Ward et al. 2001; Nilsson et al. 2007). The fundamental ecological information about the relationships between structures, processes, and functions that is needed to support the prediction of potential restoration trajectories is often lacking at the time of restoration planning (Thom 1997, 2000). Furthermore, processes occurring at regional scales that can control outcomes are too infrequently accounted for in project- or site-scale designs (National Research Council 1992; Diefenderfer et al. 2005; Palmer 2009).

It is generally agreed that the natural processes and patterns of a river system must be understood to guide restoration. Now also accepted is the concept that because of trends in environmental factors, restoration to historical or pre-historical conditions can no longer serve as the overriding goal for ecological restoration as it did in early years of practice (Ward et al. 2001; Stanford et al. 1996; SER 2004; Jackson and Hobbs 2009.). The processes and patterns of rivers are extremely complicated, with interlocked flora, fauna, and flow regimes affected by disturbance processes related to flooding and desiccation and changes along gradients both longitudinal and lateral to the main stem of the river 
(Welcomme 1979; Naiman and Décamps 1997; Junk 1999; Bunn and Arthington 2002). Near the coasts, tides introduce still further complexity into the hydrologic controlling factors of the river floodplain ecosystem (Jay and Flinchem 1997).

The importance of hydrology in the establishment and maintenance of wetland communities is well established (Mitch and Gosslink 2000). The hydrologic regime, itself a product of land elevation and flows, can be predictive of the potential plant community especially in low-relief wetlands where ecotones can occur because of very small vertical differences (Baldwin et al. 2001). In tidally influenced systems, the location of vegetation communities is also linked to landscape connectivity (Zedler et al. 1999).

The relationships between hydrologic regime and vegetation have particular importance to restoration ecologists (Sullivan 2001). Montalto and Steenhuis (2004) state the importance of documenting the hydrologic conditions of a reference marsh to provide relevance of ecological studies to restoration design. The information can be used to inform aspects of restoration design such as marsh plain elevation, vegetation-planting plans, microtopography, and tidal channel morphology (Zedler et al. 1999; Diefenderfer et al. 2008). The flood regime also is critical to the establishment and management of invasive species such as Phalaris arundinacea (reed canarygrass) (Kercher and Zedler 2004; Jenkins et al. 2008).

Shallow-water habitats have been lost in the LCRE through the combined effects of diking the floodplain for agriculture and flood control, and upriver dams and water withdrawals (Kukulka and Jay 2003b). On the Columbia River, shallow-water habitats including emergent marshes and freshwater swamps are being restored throughout the lower $235 \mathrm{~km}$ below Bonneville Dam, to support the recovery of endangered stocks of salmonids (NOAA Fisheries 2008). Large ecological restoration programs such as this one must be informed by knowledge about the fundamental relationships between hydroperiod and potential plant community development. The hydrology of this region is highly complex, in that tidal energy dominates the hydrograph from the mouth of the river to river kilometer (rkm) 135, while upstream of that, river flow is the dominant energy, as modulated by some 30 major dams of the Federal Columbia River Power System (Kukulka and Jay 2003a).

The research presented here was designed to answer the following fundamental question: How does the inundation pattern in tidal wetlands in the floodplain of the Columbia River differ along the longitudinal gradient of the river and how does this affect the plant communities found in these ecosystems? To answer this question, we must evaluate several specific questions:

- What is the inundation pattern of tidal wetlands and how does it vary relative to the complex hydrologic patterns of the river?

- Do species composition and diversity vary along the longitudinal gradient of the river?

- Does the interface between ecotones in the wetlands occur at the same or different relative elevation throughout the study area?

- Does the slope of wetlands in this system differ longitudinally?

By answering these questions, we hope to provide valuable information regarding the factors controlling wetland species composition to facilitate informed invasive species management and improve site restoration and creation practices. 


\section{B.3 Methods}

All sampling occurred from 2007-2009 in the summer between the end of June and mid-August to capture the vegetation during peak biomass and during low daytime tides to facilitate in-channel work. In general, sampling was conducted as outlined in the Protocols for Monitoring Habitat Restoration Projects in the Lower Columbia River and Estuary (Protocols; Roegner et al. 2009). Specific methods are discussed below.

\section{B.3.1 Study Area}

\section{B.3.1.1 General Description}

The study area is located on the northwest coast of the United States (Figure B.1). The LCRE extends $235 \mathrm{~km}$ from the river mouth to Bonneville Dam, the first hydrologic dam on the river. The extent of saltwater intrusion is approximately 20 to $40 \mathrm{~km}$ depending on seasonal flows (Chawla et al. 2008), while tidal influence extends to Bonneville Dam. Most of the sites in the study area are tidal freshwater wetlands, with some brackish wetlands located in the lower part of the estuary. In an inventory of the Columbia River, Christy and Putera (1992) described the "freshwater tidelands" ecosystem as being "of low relief, typically flooded or sub-irrigated at high tide, and permeated by conspicuous, dendritic and meandering tidal streams and sloughs. Cut banks, when present, show mucky soils with high organic content.”

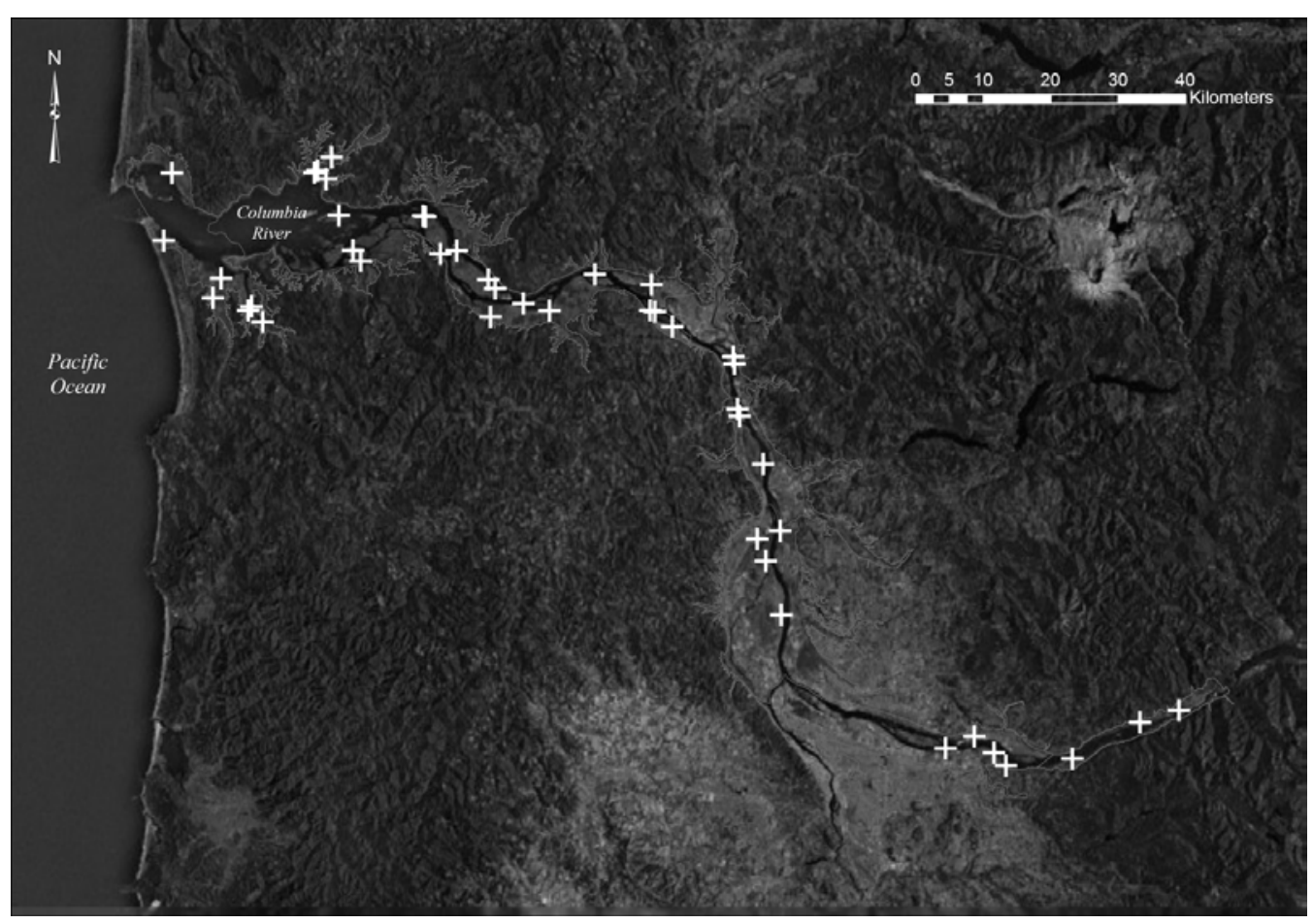

Figure B.1. LCRE Study Area

Kunze (1994) further characterized tidal freshwater wetlands in the LCRE as comprising four wetland types: the "coastal surge plain wetlands, surge plain wetlands, overflow plain wetlands, and Columbia River Gorge wetlands.” Typical surge plain wetlands are flooded during incoming tides and drain during 
low tides, and the water is fresh $(<0.5 \mathrm{ppt}$ salt). Coastal surge plain wetlands are tidal freshwater wetlands that occur along the Columbia River and its tributaries up to Cathlamet, Washington (rkm 64). The surge plain continues, with slightly different communities, from Cathlamet to Longview, Washington (rkm 105). Overflow plain wetlands occur from Longview to Skamania, Washington (rkm 225) and have limited tidal influence; water level is affected more by river flows. The floodplain in this region lacks prominent tidal channels, but contains old channels, backwater areas, ponds, and islands. Columbia River Gorge wetlands occur between Skamania and the Bonneville Dam and are dominated by high river flows. Substrates are typically coarse sand and gravel.

Substantial variation in water level occurs throughout the study area depending on river flows and tides. Our water-level data show that, during high river flows, water level in major portions of the study area can be on the order of $3.5 \mathrm{~m}$ higher than during low flow periods (Kukulka and Jay 2003a). The period of high water can last for weeks. Because wetland vegetation growth and distribution are tightly determined by prevailing water levels, understanding the magnitude and dynamics of water level in the LCRE is critical to explaining variation in shallow vegetation assemblages.

\section{B.3.1.2 Site Selection}

Sites were selected to be part of this study based on habitat type, location, and hydrogeomorphic setting. Three types of sites are included in this study as follows:

- Historical habitat - this type includes several specific habitat types such as brackish marshes, tidal freshwater marshes, tidal freshwater shrub/scrub, tidal freshwater forested swamps (dominated by Sitka spruce), and riparian woodlands (dominated by Oregon ash and Pacific willow). These sites provide the stable endpoint on the trajectory for restoration sites.

- Previously breached habitats - these sites are previously diked areas that were breached either by natural forces or by intentional restoration actions. The sites have begun their progression back to pre-diked state and therefore provide a point along the restoration trajectory.

- Created sites - these island sites are created from disposal of dredge material. The age of these sites can be estimated and the structure and function evaluated to determine potential restoration trajectories for these types of habitats.

\section{B.3.2 Metrics}

All sampling occurred in the summer between the end of June and mid-August to capture the vegetation during peak biomass and during low daytime tides to facilitate in-channel work. In general, sampling was conducted as outlined in the Protocols for Monitoring Habitat Restoration Projects in the Lower Columbia River and Estuary (Protocols; Roegner et al. 2009). Specific methods are discussed below.

\section{B.3.2.1 Vegetation Sampling}

Vegetation was sampled in all habitat types. Necessarily different methods were used at emergent marsh sites and at forested wetland sites. Emergent marsh vegetation species composition and percent cover was assessed according to the Protocols using a random sampling design within each major vegetation stratum. Transects were established at set intervals along an established "baseline” with sample plots spaced equally on each transect with a randomly selected starting point. At each sample 
plot, percent cover by species was estimated in a $1-\mathrm{m}^{2}$ quadrant using $5 \%$ increments. Sample sizes necessary to adequately represent the site relate to the diversity of the plant communities (Tiner 1999), which can vary greatly in freshwater marsh ecosystems. Therefore, final determination of sample size in the marshes was made onsite. In addition, descriptive information about the site was collected where possible to complement the vegetation monitoring. Vegetation mapping of broad plant communities was conducted at some sites, where feasible.

\section{B.3.2.2 Elevation}

At each site, a benchmark was used to reference all survey data. An established local benchmark was used if one could be located and a Trimble real-time kinematic-global positioning system (RTK) base receiver was set up over the benchmark and the coordinates were entered into the system. If an existing benchmark was not available, a temporary benchmark was established. In this case, a Trimble base receiver was set up at or near the site and GPS data were logged over a 4-to-6-hr period. The data were then sent to an automated Online Positioning User Service (OPUS) provided by the National Geodetic Survey. The OPUS data provide a Root Mean Square(d) (RMS) value for each set of static data collected by the base receiver. The RMS is the circular positional error around a point; it is an indicator of the random error associated with each surveyed point. Elevation data collected with the roving collection unit can then be corrected after the base receiver data have been processed. Data collected from the RTK were processed using Trimble Geomatics Office (TGO) software. Error estimates associated with the RTK data on average equate to approximately $4 \mathrm{~cm}$. In some cases, data were collected using the autolevel method. These data were entered into a spreadsheet and corrected using the RTK reference point elevations exported from TGO. All elevation surveys are referenced to the North American Vertical Datum of 1988 (NAVD88). Elevation data were collected for 1) a temporary benchmark if created, 2) reference points (if necessary for auto-level use), 3) vegetation sample locations, 4) longitudinal elevation surveys, 4) water-level sensors, and 5) channel cross sections.

\section{B.3.2.3 Channel Morphology}

Channel cross sections were measured to characterize the primary tidal channel at each site. If possible, five channel cross sections from the mouth of a main marsh channel to the upper extent were surveyed; intermediate cross-section surveys were conducted above the confluence of major secondary channels or equidistant along the channel if appropriate, as recommended by the Oregon Coastal Hydrogeomorphic Assessment Method (Adamus 2005).

Elevations were measured with an RTK-GPS at each point or feature of a channel cross section. Alternatively, the RTK GPS rover was used to determine the elevation of the end post(s) of the cross section and an auto-level and stadia rod were used to measure elevations relative to the end post. The lengths of the channels were delineated using a geographic information system (GIS; ESRI ArcGIS 9.3) by evaluating a combination of aerial imagery and light detection and ranging (LiDAR) data. The entire channel length was also delineated as was the extent of the surveyed area between the lower and upper cross section.

\section{B.3.2.4 Hydrology}

We used in situ water-level loggers $\left(\mathrm{HOBO}^{\circledR} \mathrm{U} 20\right.$ Water Level Logger, Onset Computer Corporation, Bourne, Massachusetts) to measure water level and temperature at most of the monitoring sites. The 
accuracy of these sensors is estimated to be approximately $2 \mathrm{~cm}$. The sensors were deployed during the summer months, logged data for approximately 1 year, and then were retrieved the following year. The exception was at Cooperage Slough, where the sensor was only deployed for 5 months during the spring and summer. At the time of deployment and retrieval, we measured the height of the sensor on the post and the water level above the sensor for elevation correction and calibration. The top of the post was surveyed as described in the elevation section above to convert the relative water levels to elevations relative to NAVD88. The data collected from these sensors are used to calculate annual hydrologic patterns and inundation times.

\section{B.3.2.5 Sediment Characterization}

Sediment cores were taken at each site in the channel and from the marsh/swamp plain. These samples were analyzed for grain size and total organic matter content by Columbia Analytical Services, Kelso, Washington. Sediment cores from sites monitored under the Estuary Partnership’s Ecosystem Monitoring program were sampled and analyzed by the U.S. Geological Survey and will be included in the final 2010 report.

\section{B.3.2.6 Accretion Rates}

Sedimentation stakes used in this study are simply polyvinyl chloride stakes separated by $1 \mathrm{~m}$ where the distance from the plane at the top of the stakes to the sediment surface is measured as accurately as possible every $10 \mathrm{~cm}$ along the 1-m distance. The stakes are deployed during the summer months and are measured 1 year later to evaluate the change in surface elevation over the year.

\section{B.3.3 Analyses}

\section{B.3.3.1 Elevation}

In marsh systems, elevation data for each vegetation plot were applied to the plant species sampled in the plot. The average, minimum, and maximum elevations were calculated for each species. In the swamp systems, average elevations for each species were calculated. Cross-section data and water-level data were corrected to real (not relative) elevations.

\section{B.3.3.2 Hydrology}

Inundation times were calculated for the marsh plain and channels. In the channels, the calculation included the time that the water level was greater than $15 \mathrm{~cm}$ in the channel and greater than the elevation of top of the bank at each cross section. These attributes were selected as those important for fish access to the channel and the surrounding wetland. Similarly, inundation of the wetland surface was calculated for the time the water level was greater than the average wetland elevation, greater than $15 \mathrm{~cm}$ above the average elevation, and greater than $1 \mathrm{~m}$ above the average wetland elevation. In the swamp systems, the average elevations for the herbaceous, shrub, and tree layers were evaluated separately. The inundation periods were calculated for the entire time the sensor was deployed and for the growing season. The growing season was based on the Natural Resource Conservation Service wetland determination table for Astoria, Oregon (NRCS 2002). This table provides the average length of the growing season based on 30 years of climate data. The most conservative estimate of season length was used and is based on the dates when the temperature is above $32^{\circ} \mathrm{F}$ for 15 out of the 30 years. The start of the growing season was determined to be April 7 and the end November 9. The frequency of inundation during the growing 
season was also limited to daylight hours (between 0900 and 1700). The evaluation of different water levels and different periods was conducted to begin to examine the inundation tolerances of the vegetation in these systems.

\section{B.4 Results}

\section{B.4.1 Plant Communities}

\section{B.4.1.1 Species Richness}

We calculated the percentage of plant species that are native and non-native at each site (Table B.1). Variability in the percent cover of non-native species is seen throughout the types of study sites (e.g., historic, breached, and created); however, a consistently higher percentage of non-native species was observed at the created sites (SI1 and SI2). We plotted the species richness based on wetland status and inundation frequency during the growing season for sites throughout the lower river and estuary (Figure B.2). In general, the species richness increased at sites found in the middle reaches of the lower river, while the composition of the type of wetland plants (based on their wetland status) remained consistent. Inundation variability at each site is demonstrated by the error bars, which represent the upper and lower elevation ranges measured in the study area. The sites in the lower reaches of the river are generally flatter with a lower elevation gradient; however, they are affected by higher tidal ranges. In contrast, the sites in the upper reaches are generally steeper with a greater elevation range and greater variability in water levels throughout the growing season due to the seasonal high river flows associated with the spring freshet. A potential explanation for the higher species richness in the middle reaches is that the tidal and fluvial extremes are somewhat moderated in these reaches, thereby allowing a greater number of species to develop throughout the growing season.

Table B.1. Total Number of Species and Number of Invasive Species Found at the Study Sites

\begin{tabular}{llcccc}
\hline Site Code & Site Name & $\begin{array}{c}\text { Number } \\
\text { of } \\
\text { Species }\end{array}$ & $\begin{array}{c}\text { Number of } \\
\text { Non-Native } \\
\text { Species }\end{array}$ & $\begin{array}{c}\text { \% Non-Native } \\
\text { Species }\end{array}$ & $\begin{array}{c}\text { \% Non-Native } \\
\text { Cover }\end{array}$ \\
\hline CSM & Cooperage Slough & 18 & 1 & 6 & 1 \\
SRM-H & Secret River high marsh & 26 & 4 & 15 & 13 \\
SRM-L & Secret River low marsh & 18 & 3 & 17 & 12 \\
WIM & Welch Island marsh & 28 & 4 & 14 & 20 \\
SIM & Sand Island marsh & 12 & 1 & 8 & 8 \\
FLM & Franz Lake marsh & 14 & 2 & 14 & 43 \\
PIM & Pierce Island marsh & 19 & 3 & 16 & 16 \\
KIB & Karlson Island natural breach & 28 & 4 & 14 & 32 \\
FCB & Ft. Clatsop natural breach & 19 & 3 & 16 & 17 \\
TBB & Trestle Bay breach & 14 & 2 & 14 & 1 \\
SI1 & Sandy Island 1 created marsh & 19 & 3 & 16 & 23 \\
SI2 & Sandy Island 2 created marsh & 19 & 5 & 26 & 70 \\
\hline
\end{tabular}

(a) Most of the non-native species identified at these sites were also invasive species. 


\section{Inundation}
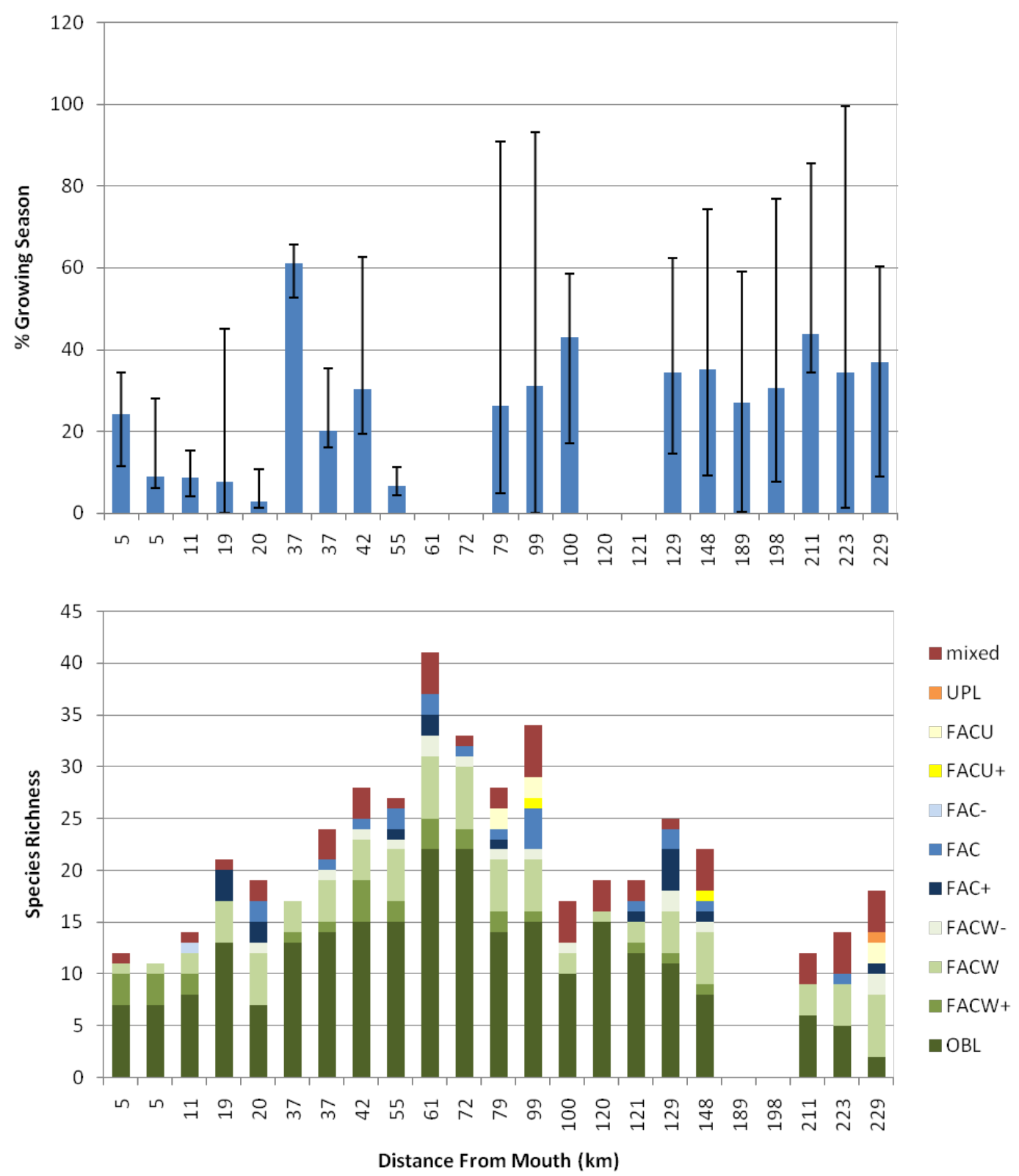

Figure B.2. Species Richness Based on Wetland Status and Inundation Frequency During the Growing Season from the Mouth to the Upper Reach of the Study Area 


\section{B.5 References}

Adamus, PR. 2005. Science Review and Data Analysis for Tidal Wetlands of the Oregon Coast. Volume 2 of a Hydrogeomorphic Guidebook. Report to Coos Watershed Association, U.S. Environmental Protection Agency, and Oregon Department of State Lands, Salem, Oregon.

Baldwin, AH, MS Egnotovich, and E Clarke. 2001. "Hydrologic Change and Vegetation of Tidal Freshwater Marshes: Field, Greenhouse, and Seed-bank Experiments.” Wetlands 21(4):519-531.

Bernhardt, ES, MA Palmer, JD Allan, G Alexander, K Barnas, S Brooks, J Carr, S Clayton, C Dahm, J Follstad-Shah, D Galat, S Gloss, P Goodwin, D Hart, B Hassett, R Jenkinson, S Katz, GM Kondolf, PS Lake, R Lave, JL Meyer, TK O'donnell, L Pagano, B Powell, and E Sudduth. 2005. "Ecology Synthesizing US river restoration efforts.” Science 308:636-637.

Bunn, S, and A Arthington. 2002. "Basic Principles and Ecological Consequences of Altered Flow Regimes for Aquatic Biodiversity.” Environmental Management 30:492-507.

Chawla, A, DA Jay, AM Baptista, M Wilkin, and C Seaton. 2008. "Seasonal variability and estuaryshelf interactions in circulation dynamics of a river-dominated estuary." Estuaries and Coasts 31(2):269-288.

Christy, JA and JA Putera. 1992. Lower Columbia River Natural Area Inventory. Report to The Nature Conservancy, Washington Field Office, Seattle, Washington.

Diefenderfer, HL and DR Montgomery. 2009. "Pool spacing, channel morphology, and the restoration of tidal forested wetlands of the Columbia River, U.S.A.” Restoration Ecology 17:158-168.

Diefenderfer HL, AM Coleman, AB Borde, and IA Sinks. 2008. "Hydraulic Geometry and Microtopography of Tidal Freshwater Forested Wetlands and Implications for Restoration, Columbia River, U.S.A.” Ecohydrology and Hydrobiology 8(2-4):339-361.

Diefenderfer, HL, RM Thom, and KD Hofseth. 2005. “A framework for risk analysis in ecological restoration projects in the U.S. Army Corps of Engineers.” Pages 57-105 in RJF Bruins and MT Heberling (eds.) Economics and Ecological Risk Assessment: Applications to Watershed Management. CRC Press, Boca Raton, Florida.

Dudgeon, D, AH Arthington, MO Gessner, ZI Kawabata, DJ Knowler, C Leveque, RJ Naiman, AH Prieur-Richard, D Soto, MLJ Stiassny, and CA Sullivan. 2006. "Freshwater Biodiversity: Importance, Threats, Status and Conservation Challenges.” Biological Reviews 81:163-82.

Dynesius, M and C Nilsson. 1994. "Fragmentation and flow regulation of river systems in the northern third of the world.” Science 266:753-762.

Jackson, ST and RJ Hobbs. 2009. “Ecological Restoration in the Light of Ecological History.” Science 325:567-569.

Jay, DA and EP Flinchem. 1997. "Interaction of fluctuating river flow with a barotropic tide: A test of wavelet tidal analysis methods.” J. Geophys. Res. 102:5705-5720. 
Jenkins, NJ, JA Yeakley, and EM Stewart. 2008. "First-Year Responses to Managed Flooding of Lower Columbia River Bottomland Vegetation Dominated by Phalaris arundinacea.” Wetlands 28(4):1018-1027.

Junk, WJ. 1999. “The Flood Pulse Concept of Large Rivers: Learning from the Tropics.” Archiv fur Hydrobiologie 115:261-80.

Kercher, SM and JB Zedler. 2004. "Flood tolerance in wetland angiosperms: a comparison of invasive and noninvasive species.” Aquatic Botany 80:89-102.

Kukulka, T and DA Jay. 2003a. Impacts of Columbia River discharge on salmonid habitat 1: A nonstationary fluvial model.” Journal of Geophysical Research 108:3293, doi:10.1029/2002JC001382.

Kukulka, T and DA Jay. 2003b. "Impacts of Columbia River discharge on salmonid habitat 2: changes in shallow-water habitat.” Journal of Geophysical Research 108:3294, doi:10.1029/2003JC001829.

Kunze, LM. 1994. Preliminary Classification of Native, Low Elevation, Freshwater Wetland Vegetation in Western Washington. Washington State Department of Natural Resources, Olympia, Washington.

Miller, RC and J Zedler. 2003. “Responses of native and invasive wetland plants to hydroperiod and water depth.” Plant Ecology 167(1):57-69.

Mitsch, WJ and JG Gosselink. 2000. Wetlands. 3rd ed., John Wiley \& Sons, Inc., New York.

Montalto, FA and TS Steenhuis. 2004. "The link between hydrology and restoration of tidal marshes in the New York/New Jersey estuary.” Wetlands 24(2):414-425.

Naiman, RJ and H Décamps. 1997. “The Ecology of Interfaces: Riparian Zones.” Annual Review of Ecology and Systematics 28:621-58.

National Oceanic and Atmospheric Administration (NOAA) Fisheries. 2008. Biological OpinionConsultation on Remand for Operation of the Federal Columbia River Power System, 11 Bureau of Reclamation Projects in the Columbia Basin and ESA Section 10(a)(1)(A) Permit for Juvenile Fish Transportation Program. National Marine Fisheries Service (NOAA Fisheries) - Northwest Region. Seattle, Washington.

National Research Council (NRC). 1992. Restoration of Aquatic Ecosystems. National Academies Press, Washington, D.C.

Natural Resource Conservation Service (NRCS). 2002. Wetland determination (WETS) table for Astoria, OR. Available at: ftp://ftp.wcc.nrcs.usda.gov/support/climate/wetlands/or/41007.txt

Nilsson, C, R Jansson, B Malmqvist, and RJ Naiman. 2007. "Restoring riverine landscapes: The challenge of identifying priorities, reference states, and techniques.” Ecology and Society 12:16. [online] URL: http://www.ecologyandsociety.org/vol12/iss1/art16/. 
Palmer, MA. 2009. "Reforming Watershed Restoration: Science in Need of Application and Applications in Need of Science.” Estuaries and Coasts 32:1-17.

Roegner, GC, HL Diefenderfer, AB Borde, RM Thom, EM Dawley, AH Whiting, SA Zimmerman, and GE Johnson. 2009. Protocols for Monitoring Habitat Restoration Projects in the Lower Columbia River and Estuary. NOAA Technical Memorandum NMFS-NWFSC-97, prepared by NOAA Fisheries and Pacific Northwest National Laboratory, Seattle, Washington, for the U.S. Army Corps of Engineers, Portland District.

Society for Ecological Restoration International (SER). 2004. The SER International Primer on Ecological Restoration. Society for Ecological Restoration International Science and Policy Working Group. Version 2: October, 2004. URL: http://www.ser.org/content/ecological_restoration_primer.asp\#5

Stanford, JA, JV Ward, WJ Liss, CA Frissell, RN Williams, JA Lichatowich, and CC Coutant. 1996. "A General Protocol for Restoration of Regulated Rivers.” Regulated Rivers: Research \& Management 12:391-413.

Sullivan, B. 2001. “Establishing vegetation in restored and created coastal wetlands.” In: JB Zedler (ed) Handbook for Restoring Tidal Wetlands. CRC Press, New York.

Thom, RM. 2000. “Adaptive Management of Coastal Ecosystem Restoration Projects.” Ecological Engineering 15:365-72.

Thom, RM. 1997. “System-Development Matrix for Adaptive Management of Coastal Ecosystem Restoration Projects.” Ecological Engineering 8:219-32.

Tiner, RW. 1999. Wetland Indicators: A Guide to Wetland Identification, Delineation, Classification, and Mapping. Lewis Publishers, Boca Raton, Florida.

Ward, JV, K Tockner, U Uehlinger, and F Malard. 2001. "Understanding Natural Patterns and Processes in River Corridors as the Basis for Effective River Restoration.” Regulated Rivers: Research and Management 17:311-323.

Welcomme, RL. 1979. Fisheries Ecology of Floodplain Rivers. Longman, London.

Zedler, JB., JC Callaway, JS Desmond, G Vivian-Smith, GD Williams, G Sullivan, AE Brewster, and BK Bradshaw. 1999. "Californian Salt-Marsh Vegetation: An Improved Model of Spatial Pattern." Ecosystems 2(1):19-35. 



\section{Appendix C}

\section{Ecological Trajectories and Salmon Habitat Functions of Historical Dike Breaches and Created Islands in the Columbia River Floodplain, USA}





\title{
Appendix C - Ecological Trajectories and Salmon Habitat Functions of Historical Dike Breaches and Created Islands in the Columbia River Floodplain, USA
}

\author{
Prepared by Heida L. Diefenderfer, Amy B. Borde, G. Curtis Roegner, \\ Earl M. Dawley, Micah T. Russell, and April S. Cameron
}

\section{C.1 Introduction}

The river floodplain is a type of wetland ecosystem that historically was highly productive and biologically diverse, but over $90 \%$ of floodplains in Europe and North America are functionally extinct (Tockner and Stanford 2002). The majority of the total water discharge in the northern third of the world is affected by dams and other water regulation, resulting in the loss of river ecosystem types and species (Dynesius and Nilsson 1994). Similarly, most species associated with temperate estuaries and coastal seas worldwide have been depleted by human activities, with the declines rapidly escalating over the past 150 to 300 years (Lotze et al. 2006). The biota of both river floodplain and estuarine wetland ecosystems are strongly affected by hydrological regimes, but the rates of evolution of adaptive responses to hydrologic alteration remain unknown (Bunn and Arthington 2002; Middleton 2002; Junk and Wantzen 2003; Lytle and Poff 2004). Preservation, ecological restoration, and environmental flow management are seen as important techniques for conserving floodplain ecosystems (Poff et al. 1997; Tockner and Stanford 2002; Tharme 2003; Arthington et al. 2006). Thus, in recent years, there have been calls to support decision-making for restoration and other alternatives by improving the understanding of ecological patterns and processes (Ward et al. 2001), implementing large-scale experiments and integrating the outcomes of case studies into broader scientific understanding (Poff et al. 2003), and in particular investigating how new environmental states are produced by the interactions of environmental changes (Naiman and Turner 2000).

As with other large, regulated rivers of the world, dikes were built throughout the floodplain and islands of the lower Columbia River and estuary (LCRE) starting in the 1890s, with approximately 99,000 acres diked by 1948 (Christy and Putera 1992). Many of the areas behind dikes had previously been tidal marshes and swamps (Thomas 1983), but these were predominantly converted to agricultural lands (Martin 1997). Prior to diking, the marshes and swamps had served as habitats for juvenile Pacific salmonids migrating from the Columbia River basin to the ocean (Rich 1920; Reimers and Loeffel 1967; Bottom et al. 2005). Residency and feeding in estuarine and tidal freshwater habitats is typical of many stocks of juvenile salmonids in large rivers of the West Coast of North America (Levy and Northcote 1982; Levings et al. 1991; Levings 1994).

Thirteen "evolutionarily significant units" (Waples 1991) of Columbia basin salmonids have been listed under the Endangered Species Act, and to benefit the recovery of populations of these fishes, the restoration of tidal freshwater and estuarine areas is presently underway (Kareiva et al. 2000; NMFS 2008). Primary methods of restoration and enhancement are hydrological reconnection (e.g., through the use of dike breaches, tide gates, and culverts) and riparian plantings (Roegner et al. 2009); habitat creation is also being planned (B. Ebberts, USACE, pers. comm. March 2010). Studies of relatively recent habitat restoration sites in the LCRE are documenting the effects of hydrological reconnection actions on habitat conditions and salmon relative to reference sites (Diefenderfer et al. 2008; Diefenderfer 
and Montgomery 2009; Roegner et al. 2010). However, there remains a need to project longer-term restoration trajectories of such sites, that is, to determine whether restored, enhanced, and created sites have the potential to achieve functional equivalency with reference sites representing the least disturbed conditions currently in existence (Simenstad and Thom 1996).

Following the Society for Ecological Restoration International (SER 2004), we define the term "restoration trajectory" as a developmental pathway of an ecosystem, including abiotic and biotic attributes, which in theory can be monitored by sequential measurements of a suite of parameters. The concept of trajectory is, however, bound with that of succession, which is extremely complex in dynamic river floodplain environments. In this sense, it is not advisable to discount the possibility of multiple stable states, thresholds, nondirectional or discontinuous development, i.e., multiple equilibrium and nonequilibrium theories of ecosystem change (Suding and Gross 2006). In fact, we have observed Phalaris arundinacea (reed canary grass), a species with mechanisms for competitive exclusion of others (Sidner et al. 2007), invade and monoculturally dominate the plant communities of early (1-4 year) restoring LCRE wetlands. Because science remains unable to successfully predict trajectories much of the time (Suding and Gross 2006), it is important to monitor attributes of restoration sites relative to the objectives of the project, evaluate outcomes relative to a system-development matrix, and adaptively manage at site and program scales (Thom 1997; Diefenderfer et al. 2005).

Three important elements of restoring riverine landscapes are prioritization, identification of reference conditions, and the selection of suitable restoration techniques (Nilsson et al. 2007). To predict and ultimately evaluate the effectiveness of the LCRE ecosystem restoration program, which involves projects by multiple agencies and non-governmental organizations, we proposed to augment short-term current project assessments in the LCRE with assessments at sites that have been historically created, restored, or accidentally breached (Diefenderfer et al. In Press). In this paper, we report the results of these assessments of historically altered sites and compare them to relatively undisturbed sites. In using the term "relatively undisturbed," we recognize that the combination of some 30 major dams together with water withdrawals, minor dams, and diking has lastingly changed the hydrograph (Kukulka and Jay 2003a, b), and therefore today's reference sites represent the effects of these hydrological controls on the ecosystem.

The purpose of this paper is to report our assessment of the present outcomes of ecological trajectories and current salmon habitat functions of three created sites, three accidentally breached sites, and one restored site in the LCRE, dating from the 1960s forward. Our purpose was to measure selected features of the environments at this time series of sites that are 1) important to their self-maintenance (e.g., plant community composition and soils), 2) important for salmonid access (e.g., channel morphology and hydrological regime), and 3) functionally significant to current restoration goals (e.g., fish assemblage), to adaptively inform the design of restoration projects and the restoration program in the LCRE.

\section{C.2 Methods}

Historically, some dikes in the LCRE have been breached because of flooding and storm damage. While many accidental breaches are repaired, a few have remained open to tidal flow and provide an opportunity to observe resulting changes in habitat conditions over time. Assuming that the time of breaching can be approximated, the estimated time since "restoration" can then be placed in a temporal context together with other restoration projects for comparison along an ecological trajectory. Historically created and restored sites also provide such an opportunity. 


\section{C.2.1 Study Site Selection}

The present location of diked areas in the LCRE was evaluated using geographic information systems (GISs) (Figure C.1). A list of potential study sites was developed in 2006 and 2007 by interviewing local experts and reviewing a U.S. Environmental Protection Agency report that evaluated the restoration potential of diked wetlands along the coast of Oregon and Washington (Simenstad and Feist 1996). The 16 sites identified through this process (Table C.1), were next remotely evaluated for exact location and hydrologic connectivity using aerial imagery, light detection and ranging (LiDAR), and a GIS. Finally, the current status of sites, including feasibility of access, was assessed by boat; on this reconnaissance survey, some sites could not be located because of faulty information in the initial reports, and many of the sites were found to be repaired, i.e., no longer breached and therefore unsuitable for the study. Therefore, the information in Table C.1 provides an update of Simenstad and Feist's data (1996) for the LCRE.

On the basis of the reconnaissance survey, seven sites were selected for this study: three created, three accidentally breached, and one restored by hydrological reconnection (Table C.2). In addition, data from our ongoing study of three recent restoration sites were included for the purpose of analyzing trends among sites with the widest possible range of ages (Table C.2); these represent tide-gate enhancement, culvert installation, dike breaching, and excavation methods. To increase the power of analyses of juvenile salmonid habitat usage, four other sites at which breaches had been repaired, or where access above the ordinary high water mark was potentially limited by private ownership, were sampled for fish but not habitat indicators.

Potential reference sites for each study site (Table C.2) were identified from an ongoing study of reference sites in the LCRE begun in 2006 (Borde et al. 2009). Reference sites were excluded if they were manmade sites. We required the same vegetation cover type (swamp or marsh). Due to a lack of reference sites, it was necessary in the case of Miller Sands to accept pairing mainland and island sites and for Goat Island to use a site from a different reach and located up a slough. In contrast, more than one reference site was identified for some of the study sites, although as a rule comparability was greater for some elements than others, e.g., hydrology, geomorphology, and vegetation. The relative elevations of paired study and restoration sites were evaluated by converting surveyed elevations to the Columbia River Datum to normalize for the longitudinal position of each site along the river gradient. 


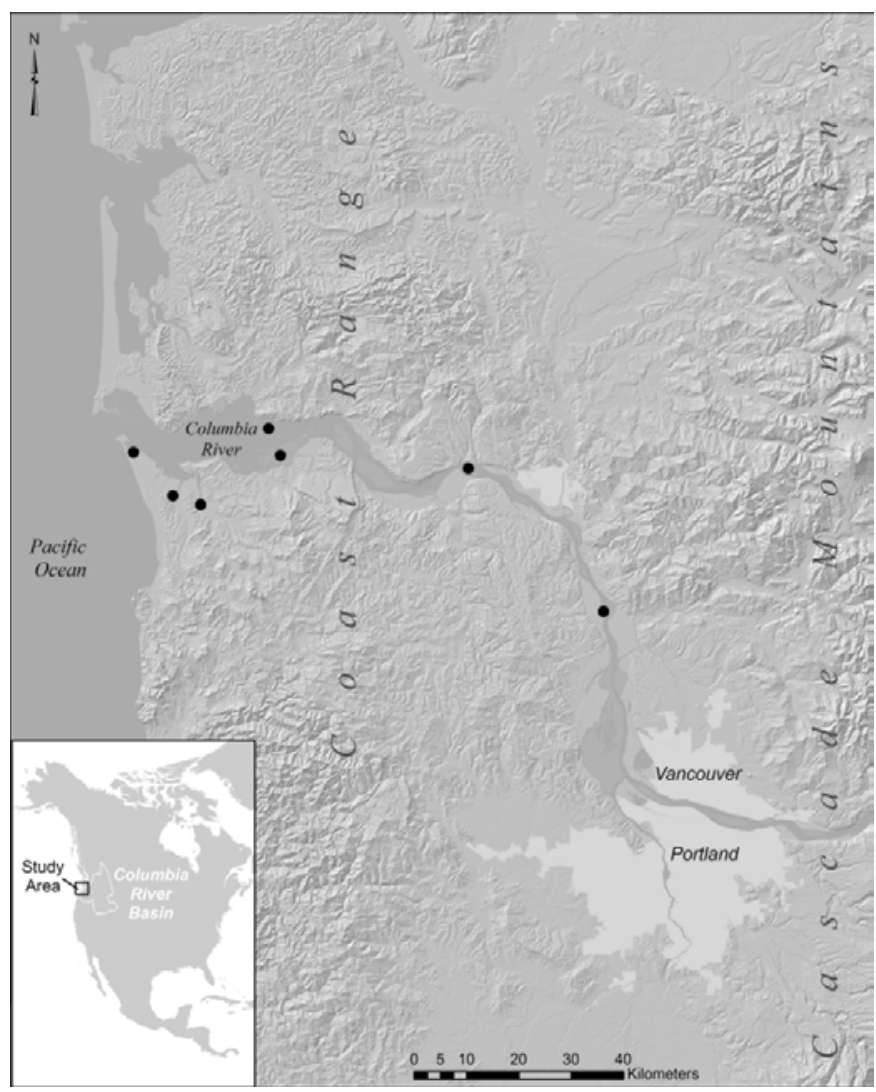

Figure C.1. Historical Breaches and Created Islands Studied Within the Lower Columbia River and Estuary

Table C.1. Potential Study Sites Evaluated in Reconnaissance

\begin{tabular}{|c|c|c|c|c|c|}
\hline Site Name & Region & Source & Type & Comments & Potential \\
\hline Blind Slough Dike & Cathlamet & 1 & Dike-breach & Breach repaired & No \\
\hline Devil's Elbow Dike & Grays & 1 & Dike-breach & No breach known in region & No \\
\hline Devil's Elbow Upriver Dike & Grays & 1 & Dike-breach & No breach known in region & No \\
\hline Ferris Creek Dike & Cathlamet & 1 & Dike-breach & No breach apparent & No \\
\hline Goat Island & Main stem & 2 & $\begin{array}{l}\text { Dredge material } \\
\text { creation }\end{array}$ & Created dredge disposal island & Yes \\
\hline Gull Island & Main stem & 2 & $\begin{array}{l}\text { Dredge material } \\
\text { creation }\end{array}$ & Created dredge disposal island & Yes \\
\hline Haven Island & Youngs & 2 & Dike-breach & $\begin{array}{l}\text { Owned by the Columbia Land Trust } \\
\text { (CLT) }\end{array}$ & Yes \\
\hline Karlson Island East & Cathlamet & 1 & Dike-breach & $\begin{array}{l}\text { Small breach apparent at east side of } \\
\text { diked area }\end{array}$ & No \\
\hline Karlson Island West & Cathlamet & 1,2 & Dike-breach & Large breach & Yes \\
\hline $\begin{array}{l}\text { Lewis and Clark River Bend } \\
\text { Dike }\end{array}$ & Youngs & 1,2 & Dike-breach & Near Ft. Clatsop & Yes \\
\hline Miller Sands & Main stem & 2,4 & $\begin{array}{l}\text { Dredge material } \\
\text { creation }\end{array}$ & Created dredge disposal island & Yes \\
\hline Svenson Island & Cathlamet & 2 & Dike-breach & $\begin{array}{l}\text { Breach only } 5 \text { years old and private } \\
\text { property concerns }\end{array}$ & No \\
\hline Tansey Point Dike & Main stem & 1 & Dike-breach & No breach apparent & No \\
\hline Tenasillahe Island Dike & Main stem & 1 & Dike-breach & Breach repaired & No \\
\hline
\end{tabular}


Table C.1. (contd)

\begin{tabular}{lccllc}
\hline \multicolumn{1}{c}{ Site Name } & \multicolumn{1}{c}{ Region } & Source & \multicolumn{1}{c}{ Type } & \multicolumn{1}{c}{ Comments } & Potential \\
\hline Trestle Bay & Main stem & 2,3 & Jetty-breach & $\begin{array}{l}\text { Restored to tidal flow in 1995 through } \\
\text { removal of 152 m of rock jetty }\end{array}$ & Yes \\
Walluski Loop Dike & Youngs & 1,2 & Dike-breach & $\begin{array}{l}\text { Existing breach } \\
\text { No }\end{array}$ & No \\
\hline
\end{tabular}

Sources: 1, Simenstad and Feist 1996; 2, local knowledge; 3, Hinton and Emmett 2000; 4, Clarain et al. 1978.

NA = not applicable.

Table C.2. History and Present Characteristics of the Study Sites Selected for Habitat and Fish Sampling

\begin{tabular}{|c|c|c|c|c|c|c|c|}
\hline $\begin{array}{l}\text { Site } \\
\text { Name }\end{array}$ & Region & $\begin{array}{l}\text { Historical } \\
\text { Condition }\end{array}$ & Date Diked & $\begin{array}{l}\text { Condition } \\
\text { at Time of } \\
\text { Action } \\
\end{array}$ & $\begin{array}{l}\text { Date of } \\
\text { Action }^{(a)}\end{array}$ & Type of Action & Potential Reference Site(s) \\
\hline & \multicolumn{7}{|c|}{ Historically Created } \\
\hline $\begin{array}{l}\text { Goat } \\
\text { Island }\end{array}$ & Main stem & & NA & Open Water & $\begin{array}{l}1900- \\
1940\end{array}$ & Creation & Cunningham Lake \\
\hline $\begin{array}{l}\text { Gull } \\
\text { Island }\end{array}$ & Main stem & & NA & Open Water & ND & Creation & Whites Is., Wallace Is. Clatskanie \\
\hline $\begin{array}{l}\text { Miller } \\
\text { Sands }\end{array}$ & Main stem & & NA & Open Water & $\begin{array}{l}1932- \\
2008\end{array}$ & Creation & $\begin{array}{l}\text { Secret River High Marsh; Welch } \\
\text { Island }^{(b)} \text {; Russian Island }\end{array}$ \\
\hline & \multicolumn{7}{|c|}{ Historically Breached (Accidental) } \\
\hline $\begin{array}{l}\text { Haven } \\
\text { Island }\end{array}$ & $\begin{array}{l}\text { Youngs } \\
\text { Bay }\end{array}$ & & $1940 \mathrm{~s}$ & $\begin{array}{c}\text { Diked } \\
\text { Farmland }\end{array}$ & 1960s?? & $\begin{array}{l}\text { Accidental } \\
\text { Dike Breach }\end{array}$ & Grant Island \\
\hline $\begin{array}{l}\text { Karlson } \\
\text { Island } \\
\text { West }\end{array}$ & $\begin{array}{l}\text { Cathlamet } \\
\text { Bay }\end{array}$ & & $\begin{array}{l}\text { Prior to } \\
1936^{(\mathrm{c})}\end{array}$ & $\begin{array}{c}\text { Diked } \\
\text { Farmland }\end{array}$ & $\begin{array}{l}\text { Between } \\
1953 \text { and } \\
1981\end{array}$ & $\begin{array}{l}\text { Accidental } \\
\text { Dike Breach }\end{array}$ & $\begin{array}{l}\text { Welch Island }^{(\mathrm{b})} \text {; Karlson Island } \\
\text { Swamp; Secret River High Marsh; } \\
\text { Russian Island }\end{array}$ \\
\hline \multirow[t]{2}{*}{$\begin{array}{l}\text { Ft. } \\
\text { Clatsop }\end{array}$} & $\begin{array}{l}\text { Youngs } \\
\text { Bay (Lewis } \\
\text { \& Clark } \\
\text { River) }\end{array}$ & & Early 1900s & $\begin{array}{c}\text { Diked } \\
\text { Wetland }\end{array}$ & 1961 & $\begin{array}{l}\text { Accidental } \\
\text { Dike Breach }\end{array}$ & Vera Reference \\
\hline & \multicolumn{7}{|c|}{ Restoration/Enhancement (Historical) } \\
\hline $\begin{array}{l}\text { Trestle } \\
\text { Bay }\end{array}$ & Main stem & Bay & $\begin{array}{l}\text { Jetty } \\
\text { Constructed } \\
\text { late } 1800 \mathrm{~s}\end{array}$ & $\begin{array}{c}\text { Restricted } \\
\text { Tidal Flow, } \\
\text { Fish Access }\end{array}$ & 1995 & $\begin{array}{l}\text { Planned Jetty } \\
\text { Breach (152 m) }\end{array}$ & Chinook, Vera Reference \\
\hline & \multicolumn{7}{|c|}{ Restoration/Enhancement (Recent) } \\
\hline $\begin{array}{l}\text { Crims } \\
\text { Island }\end{array}$ & Main stem & & NA & $\begin{array}{l}\text { Wet Pasture } \\
\text { (supra- } \\
\text { tidal) }\end{array}$ & 2005 & $\begin{array}{l}\text { Grading, } \\
\text { Channel } \\
\text { Excavation }\end{array}$ & Bradbury Slough \\
\hline $\begin{array}{l}\text { Kandoll } \\
\text { Farm }\end{array}$ & $\begin{array}{l}\text { Tributary } \\
\text { (Grays } \\
\text { Bay) }\end{array}$ & $\begin{array}{l}\text { Sitka } \\
\text { spruce } \\
\text { swamp }\end{array}$ & & $\begin{array}{c}\text { Diked } \\
\text { Farmland }\end{array}$ & 2005 & $\begin{array}{l}\text { Tide-Gate } \\
\text { Removal, } \\
\text { Culvert } \\
\text { Installation, } \\
\text { Dike Breaching }\end{array}$ & Seal Slough Swamp \\
\hline $\begin{array}{l}\text { Vera } \\
\text { Slough }\end{array}$ & $\begin{array}{l}\text { Youngs } \\
\text { Bay }\end{array}$ & & & $\begin{array}{l}\text { Diked } \\
\text { Wetland }\end{array}$ & 2005 & $\begin{array}{l}\text { Tide-Gate } \\
\text { Replacement }\end{array}$ & Vera Reference \\
\hline
\end{tabular}

(a) Action means restoration, creation, or accidental breaching.

(b) Welch Island is on the order of a meter higher than Miller Sands or Karlson Island, but it is the only reference site in the area that is an island so results are compared to more than one reference site.

(c) Christy and Putera (1992)

NA = not applicable. 


\section{C.2.2 Sampling the Sites}

Both the rationale behind the metrics adopted for rapid assessment of the sites and the specific sampling methods are detailed in the Protocols for Monitoring Habitat Restoration Projects in the Lower Columbia River and Estuary, which we developed during the course of this study (Roegner et al. 2009). The rationale is based on a conceptual model of estuarine processes and anticipated effects of hydrological reconnection actions on physical and biological structures, processes, and functions. Based on this model, our methods for the rapid assessment of the seven historical sites were intended to capture the hydrological regime, soils and sediments, channel morphology, water properties, plant community, fish assemblage, and fish diet. In general, habitat sampling was conducted in one short (2- to 3-day) effort at each site; fish sampling used beach seines and occurred 1 to 3 times per site, and three metrics were sampled for a 1-year period: sediment accretion rate, water level, and water temperature. Sampling methods are summarized briefly in Table C.3. Comparable data for the three recent restoration sites were drawn from our ongoing intensive monitoring of these sites (Diefenderfer et al. 2008; Diefenderfer et al. In Revision; Roegner et al. 2010).

Table C.3. Sampling Design and Methods

\begin{tabular}{|c|c|c|c|}
\hline Indicator & Metric & Method/Equipment & Frequency/Duration \\
\hline Hydrologic Regime & Water Pressure & HOBO $^{\circledR}$ Level Logger & Hourly/1 year \\
\hline Hydrologic Regime & Topography & Survey $^{(\mathrm{a})}$ & $1 X$ \\
\hline Hydrologic Regime & Sediment Accretion Rate & Sediment Stakes & 2X/1 year \\
\hline Soils and Sediments & Grain Size, TOC & Sediment Corp & $1 X$ \\
\hline Channel Morphology & 5, Cross Sections & Survey $^{(\mathrm{a})}$ & $1 \mathrm{X}$ \\
\hline Water Properties & Temperature & HOBO Level Logger & Hourly/1 year \\
\hline Plant Community & $\begin{array}{l}\text { Percent Cover/Diversity/Species } \\
\text { Richness }\end{array}$ & $\begin{array}{l}\text { Systematic Sampling with } \\
\text { Random Start: } 1 \mathrm{~m}^{2} \text { Plots }\end{array}$ & $1 \mathrm{X}$ \\
\hline Plant Community & Elevation Gradient & $\begin{array}{l}\text { Longitudinal Survey with RTK- } \\
\text { GPS }\end{array}$ & $1 \mathrm{X}$ \\
\hline $\begin{array}{l}\text { Plant Community/ } \\
\text { Landscape }\end{array}$ & General Morphology & Photo Point & $1 \mathrm{X}$ \\
\hline Fish Assemblage & $\begin{array}{l}\text { Presence/Diversity/Species } \\
\text { Richness }\end{array}$ & Beach Seine $^{(b)}$ & $1-3 X$ \\
\hline Salmonid Diet & Gut Contents & Taxonomic Analysis & $1-3 X$ \\
\hline
\end{tabular}

(a) Survey methods included both real-time kinematic, global positioning system (RTK-GPS) and auto-level. (b) At one site, Kandoll Farm, trap nets were used due to the unsuitability of physical conditions. TOC $=$ total organic carbon.

The only metrics not detailed by Roegner et al. (2009) and Roegner et al. (In Press) were soil/sediment sampling and fish diets. Sediment cores approximately $10 \mathrm{~cm}$ deep were taken at each site, one in the channel and one from the marsh/swamp plain. These samples were analyzed for grain size and total organic matter content. Salmonids were anesthetized with a 50-mg/L solution of tricaine methane sulfonate (MS-222) before measurement. Stomach contents of suitably sized and anesthetized juvenile coho and Chinook salmon were sampled by gastric lavage, a non-lethal sampling method that uses filtered water to evacuate fish stomachs (Seaburg 1957). Samples were fixed with $10 \%$ formalin, and in the lab the stomach contents were wet-weighed and then sorted and identified to the lowest possible taxonomic level (depending on the extent of digestion and taxonomic authority). For analysis, we grouped the data into major taxa categories to emphasize dominant prey groups by count and weight. Diet data metrics were recorded as percent numerical and gravimetric prey compositions, which were used to calculate an 
index of relative importance (IRI). IRI is determined as $\% \mathrm{O} x(\% \mathrm{~N}+\% \mathrm{~W})$, where $\% \mathrm{O}$ is the frequency of occurrence and \%N and \%W were the proportions by number and weight, respectively (Pinkas et al. 1971). The \%IRI for salmon was computed as IRI / $\sum$ IRI. This index indicates the relative level at which the prey categories were consumed by juvenile salmon.

We also closely examined all salmon for adipose-fin clips or other external marks indicating hatchery origin. However, because only a proportion of hatchery-derived fish are marked, it is likely that we underestimated the total number of hatchery-derived fish.

\section{C.3 Results}

Results for the study sites are detailed for 1) the physical controlling factors on the biota, 2) the plant communities, and 3) fish assemblages and salmonid diets. The relationships between site age and the response variables are documented. Created sites are compared with historical breaches. Finally, study sites are compared to reference sites for selected metrics.

\section{C.3.1.1 Hydrologic Regime and Water Properties}

For the sample year, water level was greater than or equal to marsh elevation at Karlson Island 30.3\% of the time (Table C.4). In addition, the average vegetation plot elevation was inundated by at least $15 \mathrm{~cm}$ of water $23.7 \%$ of the year and by over $1 \mathrm{~m}$ of water only $0.8 \%$ of the year. This is based on data from a sensor that was located in the channel and was below water level for $96 \%$ of the time that year.

Table C.4. Inundation Times at the Average Marsh Elevation at Karlson Island

\begin{tabular}{|c|c|c|c|c|c|}
\hline \multirow[b]{2}{*}{ Location } & \multirow[b]{2}{*}{$\begin{array}{c}\text { Average } \\
\text { Elevation } \\
\text { (m, NAVD88) }\end{array}$} & \multicolumn{2}{|c|}{ Deployment Period } & \multicolumn{2}{|c|}{ Growing Season } \\
\hline & & $\begin{array}{l}\text { Inundation } \\
\text { Time } \\
\text { (days) }\end{array}$ & $\%$ Time & $\begin{array}{l}\text { Inundation } \\
\text { Time (days) }\end{array}$ & $\begin{array}{c}\% \\
\text { Time }\end{array}$ \\
\hline Sensor & 0.550 & 323 & 95.4 & 60.8 & 96.0 \\
\hline Marsh Elevation & 1.849 & 124 & 36.7 & 19.2 & 30.3 \\
\hline Marsh Elevation $+15 \mathrm{~cm}$ & 1.999 & 104 & 30.5 & 15.0 & 23.7 \\
\hline Marsh Elevation +1 m & 2.849 & 9.02 & 2.66 & 0.48 & 0.80 \\
\hline
\end{tabular}

\section{C.3.1.2 Channel Morphology}

Of the historical breaches, Haven Island and Karlson Island have a cross-sectional width at the mouth of the main channel that is on the order of $40 \mathrm{~m}$, while at Trestle Bay the width is closer to $30 \mathrm{~m}$ and at Fort Clatsop it is $20 \mathrm{~m}$ (Table C.5; Figure C.2). At the four historically breached sites, the up-channel progression is relatively orderly, with generally decreasing top width and cross-sectional area at each cross section upstream of the last. The three created sites-Miller Sands, Goat Island, and Gull Islandappear to be quite different. Perhaps of the three, Gull Island, with approximate top width at mouth of $30 \mathrm{~m}$, has the most developed channel banks and orderly decrease in channel size upstream. At Miller Sands, there is very little depth to the channels or bank development, and Goat Island has uneven bank development. 

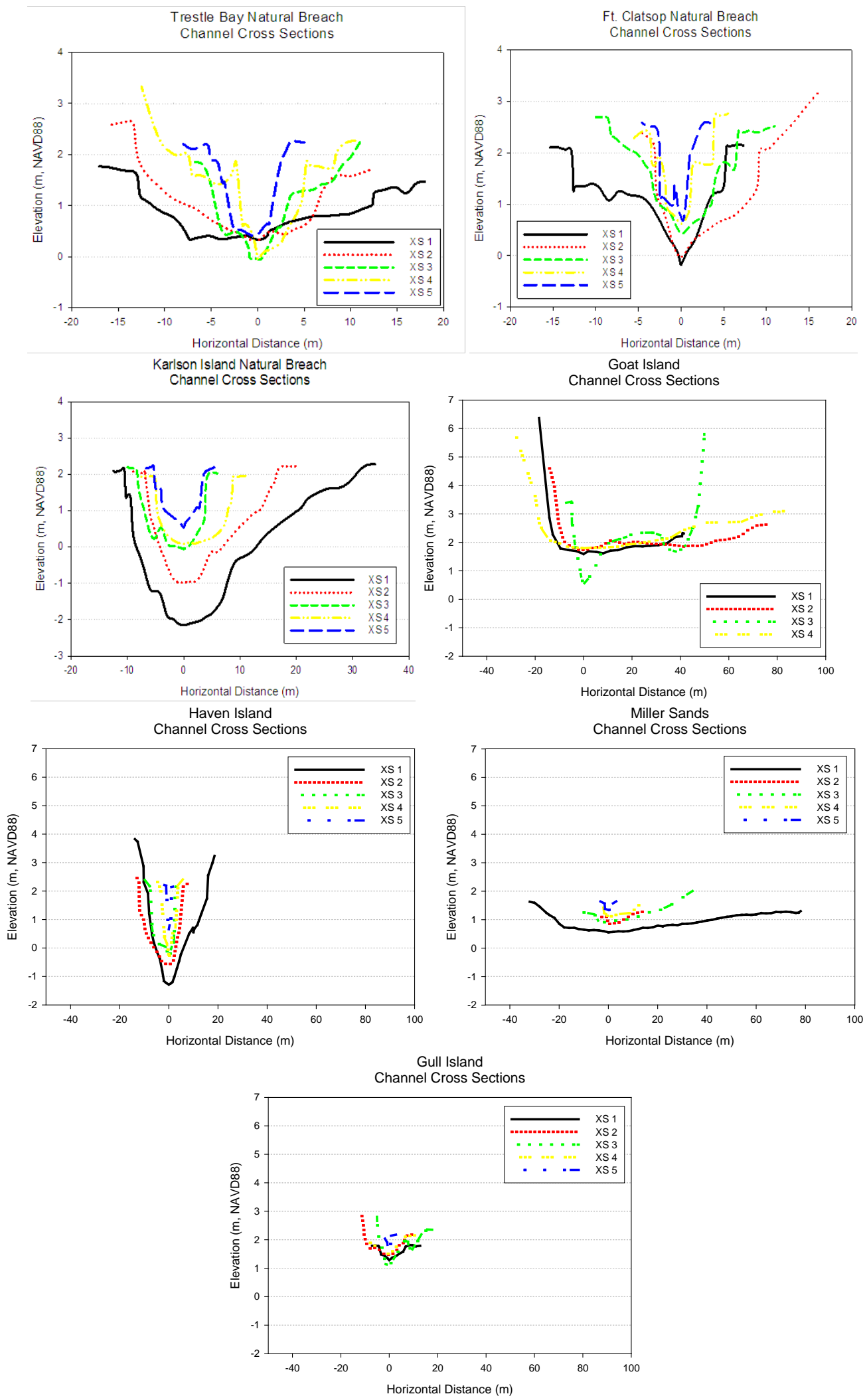

Figure C.2. Channel Cross Sections from the Channel Mouth (in black) to the Uppermost Cross Section (in blue; yellow for Goat Island, on which only four cross sections were surveyed) 
Table C.5. Characteristics and Inundation Frequencies of Channel Cross Sections

\begin{tabular}{|c|c|c|c|c|c|c|c|c|c|}
\hline \multirow[b]{2}{*}{$\begin{array}{c}\text { Site } \\
\text { Code }\end{array}$} & \multirow[b]{2}{*}{$\begin{array}{c}\text { Cross } \\
\text { Section }\end{array}$} & \multicolumn{6}{|c|}{ Physical Metrics } & \multicolumn{2}{|c|}{ Inundation } \\
\hline & & $\begin{array}{c}\text { Bank } \\
\text { Elev } \\
(\mathrm{m})\end{array}$ & $\begin{array}{l}\text { Thalweg } \\
\text { Elev (m) }\end{array}$ & $\begin{array}{c}\text { Channel } \\
\text { Depth } \\
\text { (m) }\end{array}$ & $\begin{array}{c}\text { Cross- } \\
\text { Section } \\
\text { Area } \\
\left(\mathrm{m}^{2}\right)\end{array}$ & $\begin{array}{c}\text { Channel } \\
\text { Width (m) }\end{array}$ & $\begin{array}{c}\text { Width:D } \\
\text { epth } \\
\text { Ratio }\end{array}$ & $\begin{array}{l}\text { \% Time } \\
\text { WL > } \\
15 \mathrm{~cm} \text { in } \\
\text { Channel }\end{array}$ & $\begin{array}{c}\text { \% Time } \\
\text { WL > } \\
\text { Top } \\
\text { Channel } \\
\text { Bank }\end{array}$ \\
\hline \multicolumn{10}{|c|}{ Previously Breached Marsh } \\
\hline \multirow{5}{*}{ TBB } & 1 (mouth) & 1.466 & 0.331 & 1.135 & 21.20 & 30.89 & 27.22 & ND & ND \\
\hline & 2 & 1.689 & 0.309 & 1.380 & 18.25 & 24.16 & 17.51 & ND & ND \\
\hline & 3 & 1.859 & -0.043 & 1.902 & 14.95 & 16.51 & 8.68 & ND & ND \\
\hline & 4 & 2.273 & -0.040 & 2.313 & 19.13 & 21.00 & 9.08 & ND & ND \\
\hline & 5 & 2.205 & 0.434 & 1.771 & 9.89 & 11.38 & 6.43 & ND & ND \\
\hline \multirow{5}{*}{ FCB } & 1 (mouth) & 2.106 & -0.174 & 2.280 & 21.36 & 19.92 & 8.74 & ND & ND \\
\hline & 2 & 2.026 & -0.029 & 2.055 & 16.86 & 12.28 & 5.98 & ND & ND \\
\hline & 3 & 2.371 & 0.436 & 1.935 & 14.98 & 14.94 & 7.72 & ND & ND \\
\hline & 4 & 2.347 & 0.622 & 1.725 & 7.12 & 7.45 & 4.32 & ND & ND \\
\hline & 5 & 2.015 & 0.760 & 1.255 & 3.31 & 3.67 & 2.93 & ND & ND \\
\hline \multirow{5}{*}{ KIB } & 1 (mouth) & 2.089 & -2.153 & 4.242 & 91.26 & 41.75 & 9.84 & 100 & 14 \\
\hline & 2 & 2.038 & -0.978 & 3.016 & 44.14 & 23.50 & 7.79 & 100 & 14 \\
\hline & 3 & 2.050 & -0.055 & 2.105 & 20.28 & 13.26 & 6.30 & 88 & 8 \\
\hline & 4 & 1.831 & 0.084 & 1.747 & 19.93 & 13.69 & 7.84 & 71 & 5 \\
\hline & 5 & 2.156 & 0.536 & 1.620 & 10.00 & 10.26 & 6.33 & 64 & 8 \\
\hline
\end{tabular}

$\mathrm{WL}$ = water level; ND = sensor not yet retrieved; TBB = Trestle Bay Breach; FCB = Ft. Clatsop Breach; KIB = Karlson Island Breach

\section{C.3.1.3 Plant Community and Landscape}

At the Trestle Bay historical restoration site and Fort Clatsop historical breach site, single species clearly dominated the plant communities: Carex lyngbyei and Carex obnupta, respectively (Figure C.3). Species richness at these sites was 14 and 19. Glyceria striata was a subdominant species at Trestle Bay. The Karlson Island historical breach had no species with $>15 \%$ relative cover and 4 species with $>10 \%$ relative cover, in descending order: Myosotis species, Lythrum salicaria, Carex obnupta, and Phalaris arundinacea. Miller Sands was also co-dominated by four species, in descending order: Myosotis species, Eleocharis acicularis, Lythrum salicaria, and Callitriche heterophylla. Goat Island, a created site, was co-dominated by Eleocharis palustris and Phalaris arundinacea and had a species richness of 24. Gull Island was dominated by three plant species between 15\% NAVD 88 and 25\% relative cover: Myosotis species, Carex obnupta, and Eleocharis palustris. Haven Island had a species richness of 20, and three species present at $>10 \%$ relative cover, in descending order: Schoenoplectus tabernaemontani (formerly Scirpus), Carex lyngbyei, and Phalaris arundinacea. The highest plant species richnesses observed were 28 at Karlson Island and 30 at Gull Island. 

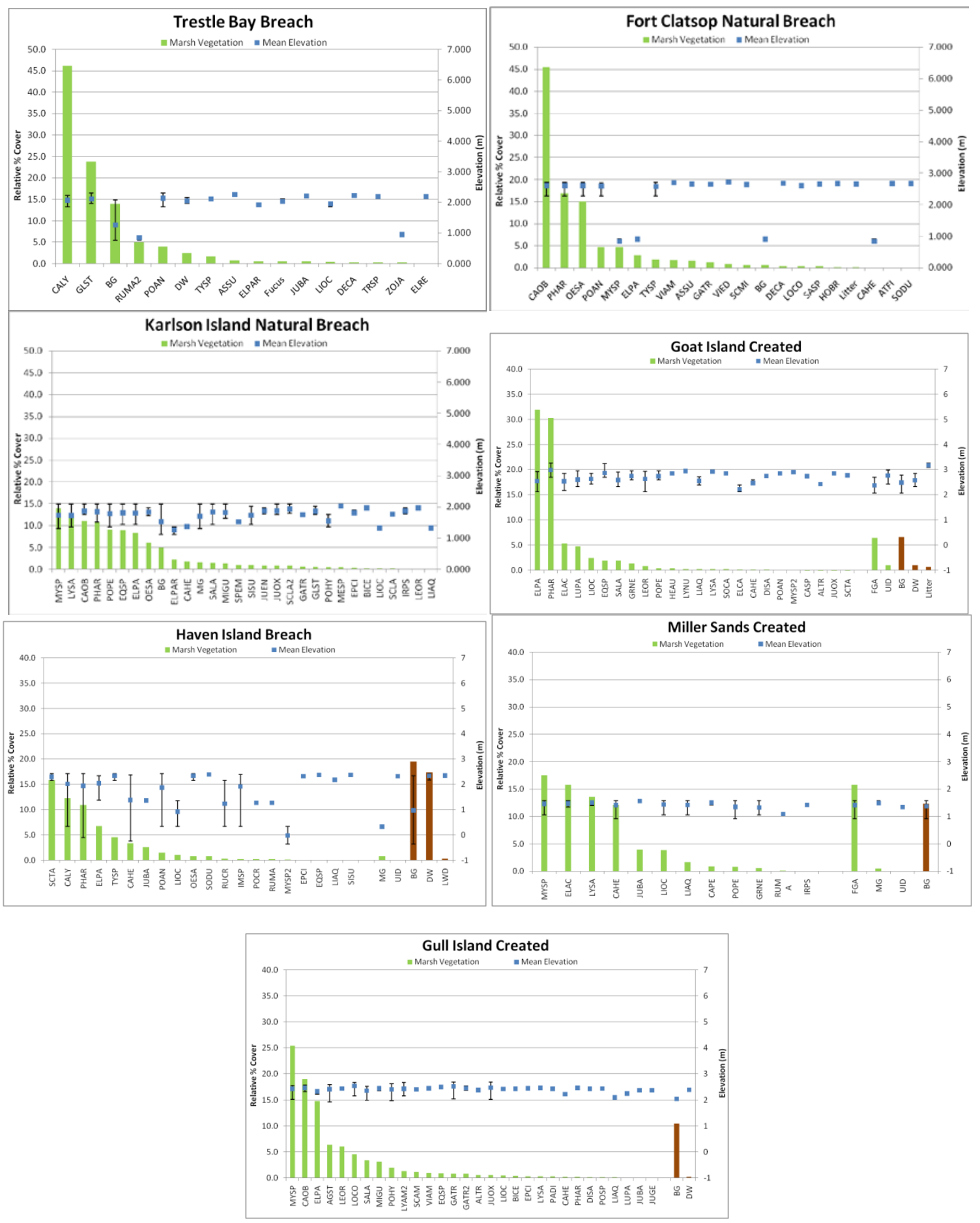

Figure C.3. Relative Percent Cover and Elevation for Plant Species in Historically Breached and Created Marshes. Four-letter codes on the $\mathrm{x}$-axis represent the first two letters of the genus and species. $\mathrm{BG}=$ bare ground, $\mathrm{DW}=$ debris wrack, FGA = filamentous green algae, $\mathrm{LWD}=$ large woody debris, MG = mixed pasture grasses, UID = unidentified species.

The introduced and invasive species Lythrum salicaria (purple loosestrife) has a $20 \%$ to $25 \%$ relative dominance at Trestle Bay, $10 \%$ to $15 \%$ relative dominance at Miller Sands, and was present $(<1 \%)$ at Karlson Island. The invasive species Phalaris arundinacea (reed canarygrass) was present at all sites, 
except Miller Sands and Trestle Bay. However, Miller Sands had a high level of plant diversity that was not captured by the proximal plot design, including upland areas with Picea species and Arctostaphylos uva-urse, likely because of the extensive plantings made at the time of creation (Clarain et al. 1978). As an example, locations at Miller Sands had the most extensive development of the introduced species Iris pseudacorus (yellow flag iris) that we have observed on more than 50 sites sampled in the LCRE, although it appeared on only one plot within the sampled area. We hypothesize that this is because, according to Clarain et al. (1978), it was planted at the site. Three sites were dominated by Myosotis species, which were classified to genus only due to the frequent lack of plant parts needed to classify to species. The Columbia River estuary is within the range of 10 Myosotis species, 7 of which were introduced (plants.usda.gov; accessed 18 February 2010).

None of the sites exceeded 3 m NAVD88 in elevation (Figure C.3). Most plant species elevations were between $1 \mathrm{~m}$ NAVD88 and $3 \mathrm{~m}$ NAVD88. The created sites showed the narrowest elevation ranges, $<1 \mathrm{~m}$ each, although Karlson Island also had an elevation range for plant species of about $1 \mathrm{~m}$. While our estuary-wide studies have shown that Phalaris arundinacea occupies a wide elevation band, and we have hypothesized that this contributes to its competitive advantage (see Appendix B), that was not shown in these created and historically breached sites. Only at Haven Island did it occupy $>2 \mathrm{~m}$ vertical, and five other plant species at that site also occupied wide vertical bands. Fort Clatsop and Goat Island were the highest of the sites, near 3 m NAVD88, with Gull Island just below that elevation. Trestle Bay was at approximately $2 \mathrm{~m}$ NAVD88. Karlson Island and Miller Sands were between $1 \mathrm{~m}$ NAVD88 and $2 \mathrm{~m}$ NAVD88. Haven Island had the broadest elevation range, from below $0 \mathrm{~m}$ NAVD88 to above $2 \mathrm{~m}$ NAVD88.

\section{C.3.1.4 Fish Assemblage, Salmonid Diet, and Water Properties}

Fish catch per unit effort (CPUE), diversity, and species richness at restoration and reference sites were all relatively low compared with similar samples acquired from Columbia River main stem sites (

Table C.6). However, values were similar between samples taken inside and outside of breached areas. We captured a total of 17 species of fish. The highest overall species richness was seven, found inside the Goat Island breach site. Mean overall species richness was only 3.4 compared with a mean value of 13 for a similar time period at main stem sites (Roegner et al. 2008). As is typical for Columbia River shallow-water fish assemblages, threespine stickleback composed the bulk of the catch (90.3\%). Chinook salmon were the second most abundant species (4.2\%), followed by staghorn sculpin (1.2\%). All other species each constituted less than $1 \%$ of the total catch (

Table C.6). As a consequence, values of the Shannon-Weiner diversity index (H') were generally < 1.0 (overall mean H’ was 0.46 , which is similar to Columbia River main stem values), indicating a relatively depauperate fish fauna.

Chinook salmon were the only abundant salmonid sampled. This is partially because we concentrated sampling in May through August when subyearling Chinook are migrating. Chum salmon peak migration is in April, and coho migrate to the ocean as yearlings, a life-history pattern that may not commonly use the types of wetlands we sampled. Overall, Chinook salmon abundance peaked in June (Figure C.4a) and decreased with increasing temperature (Figure C.4b), but salmon were present at temperatures up to $21^{\circ} \mathrm{C}$. 
Table C.6. Fish Diversity at Historically Breached and Created Sites

\begin{tabular}{|c|c|c|c|c|c|c|c|c|c|c|c|c|c|c|c|c|c|c|c|}
\hline \multirow[b]{2}{*}{ Location } & \multirow[b]{2}{*}{ Site } & \multirow[b]{2}{*}{ Date } & \multirow[b]{2}{*}{ Rep } & \multicolumn{13}{|c|}{ Species $>0.10 \%$ of total } & \multirow[b]{2}{*}{$\mathrm{N}$} & \multirow[b]{2}{*}{$\mathrm{S}$} & \multirow[b]{2}{*}{$\mathrm{H}^{\prime}$} \\
\hline & & & & Chin & Coho & Chum & Stick & Stag & Starry & Shiner & Pea & Shad & Kill & Sucker & Cottid & $<1.0 \%$ & & & \\
\hline \multirow{3}{*}{ Goat } & \multirow{2}{*}{ Inside } & 6/16/2009 & 1 & 7 & & & 175 & & 9 & & 8 & & 3 & 6 & & 1 & 209 & 7 & 0.71 \\
\hline & & $6 / 16 / 2009$ & 2 & 8 & & & 95 & & 5 & & 4 & & 10 & & & & 122 & 5 & 0.82 \\
\hline & Outside & 6/16/2009 & & 12 & & & 90 & 1 & 5 & & 2 & & & & & 1 & 111 & 6 & 0.71 \\
\hline \multirow{9}{*}{ Karlson } & \multirow{6}{*}{ Inside } & \multirow{2}{*}{$5 / 28 / 2008$} & 1 & 29 & & 1 & 530 & & & & & & & & & & 560 & 3 & 0.22 \\
\hline & & & 2 & 54 & & 1 & 1668 & & 1 & & 5 & & & & & & 1729 & 5 & 0.17 \\
\hline & & \multirow{2}{*}{ 6/30/2008 } & 1 & 6 & & & 29 & & & & & & & & & & 35 & 2 & 0.46 \\
\hline & & & 2 & 14 & & & 201 & & & & 2 & & & & & & 217 & 3 & 0.29 \\
\hline & & \multirow{2}{*}{$9 / 2 / 2008$} & 1 & 2 & & & 55 & & & & & & & & & & 57 & 2 & 0.15 \\
\hline & & & 2 & 1 & & & 230 & & & 1 & 2 & & & & 1 & & 235 & 5 & 0.13 \\
\hline & & 5/28/2008 & & 47 & 1 & & 1313 & 4 & 19 & & & & & & & 1 & 1385 & 6 & 0.25 \\
\hline & Outside & 6/30/2008 & & 10 & & & 61 & & 1 & & & & & & & & 72 & 3 & 0.47 \\
\hline & & $9 / 2 / 2008$ & & & & & 175 & & & & & 1 & & & & & 176 & 2 & 0.04 \\
\hline \multirow{6}{*}{ Svensen } & \multirow{3}{*}{ Inside } & 5/28/2008 & & 178 & & & 112 & 1 & & & & 5 & & & & & 296 & 4 & 0.76 \\
\hline & & 6/30/2008 & & 7 & & & 79 & & 2 & & 5 & & & & & & 93 & 4 & 0.57 \\
\hline & & $9 / 2 / 2008$ & & 13 & & & 80 & & & & & & & & & & 93 & 2 & 0.40 \\
\hline & \multirow{3}{*}{ Outside } & 5/28/2008 & & 49 & & & 100 & 5 & 4 & & & & 4 & & & & 162 & 5 & 0.95 \\
\hline & & 6/30/2008 & & 33 & & & 128 & & 1 & & 1 & & 1 & & & & 164 & 5 & 0.61 \\
\hline & & $9 / 2 / 2008$ & & 3 & & & 328 & & & & 2 & 6 & & & & & 339 & 4 & 0.18 \\
\hline \multirow{5}{*}{ Miller Sands } & \multirow{2}{*}{ Outside } & 4/29/2009 & & 1 & & & 280 & & 3 & & & & & & & & 284 & 3 & 0.08 \\
\hline & & 5/28/2009 & & 19 & & & 1 & 1 & 1 & & & & & & & & 22 & 4 & 0.55 \\
\hline & \multirow{3}{*}{ Inside } & 4/29/2009 & & 4 & & & 300 & 10 & & & & & & & & & 314 & 3 & 0.21 \\
\hline & & 5/28/2009 & & 70 & & & 162 & 40 & 13 & & & 2 & & & & 4 & 291 & 6 & 1.17 \\
\hline & & 8/17/2009 & & 2 & & & & & 3 & & 1 & & & & & & 6 & 3 & 1.01 \\
\hline
\end{tabular}


Table C.6. (contd)

\begin{tabular}{|c|c|c|c|c|c|c|c|c|c|c|c|c|c|c|c|c|c|c|c|}
\hline \multirow[b]{2}{*}{ Location } & \multirow[b]{2}{*}{ Site } & \multirow[b]{2}{*}{ Date } & \multirow[b]{2}{*}{ Rep } & \multicolumn{13}{|c|}{ Species $>0.10 \%$ of total } & \multirow[b]{2}{*}{$\mathrm{N}$} & \multirow[b]{2}{*}{$\mathrm{S}$} & \multirow[b]{2}{*}{$\mathrm{H}^{\prime}$} \\
\hline & & & & Chin & Coho & Chum & Stick & Stag & Starry & Shiner & Pea & Shad & Kill & Sucker & Cottid & $<1.0 \%$ & & & \\
\hline \multirow{6}{*}{ Wallooskee } & \multirow{3}{*}{ Inside } & $5 / 28 / 2009$ & & & & & 30 & 1 & & & 6 & & & & & & 37 & 3 & 0.56 \\
\hline & & 6/24/2009 & & 3 & & & 77 & 1 & & & 3 & & 2 & & & & 86 & 5 & 0.47 \\
\hline & & 8/17/2009 & & & & & 1 & & & 1 & & & & & & & 2 & 2 & 0.69 \\
\hline & \multirow{3}{*}{ Outside } & $5 / 28 / 2009$ & & 10 & & & 284 & 2 & 1 & & 3 & 18 & & & & & 318 & 6 & 0.47 \\
\hline & & 6/24/2009 & & 2 & & & 25 & & & & & & & & & & 27 & 2 & 0.26 \\
\hline & & 8/17/2009 & & & & & 14 & & & & & & & & & & 14 & 1 & 0.00 \\
\hline Grant & Inside & 6/24/2009 & & 1 & & & 9 & & & & & & & & & & 10 & 2 & 0.33 \\
\hline \multirow{3}{*}{ Haven Island } & \multirow{2}{*}{ Inside } & 6/24/2009 & & & & & 111 & & & & 1 & 1 & & & & & 113 & 3 & 0.10 \\
\hline & & 8/17/2009 & & & & & 645 & & & 4 & & & & & 2 & & 651 & 3 & 0.06 \\
\hline & Outside & 8/17/2009 & & 1 & & & 105 & & 1 & 31 & & & & & 5 & & 143 & 5 & 0.74 \\
\hline \multirow{9}{*}{ Vera Slough } & \multirow{3}{*}{ Inside } & \multirow{3}{*}{$6 / 5 / 2009$} & 1 & & & & 413 & 34 & & & & & & & & & 447 & 2 & 0.27 \\
\hline & & & 2 & & & & 352 & 6 & & & & & & & & & 358 & 2 & 0.09 \\
\hline & & & 3 & 2 & & & 136 & 2 & & & & & & & & & 140 & 3 & 0.15 \\
\hline & \multirow{3}{*}{ Outside } & \multirow{3}{*}{$6 / 5 / 2009$} & 1 & & & & 150 & & & & & 1 & & & & & 151 & 2 & 0.04 \\
\hline & & & 2 & 1 & & & 41 & & & & & & & & & & 42 & 2 & 0.11 \\
\hline & & & 3 & & & & 82 & 1 & & & & & & & & & 83 & 2 & 0.07 \\
\hline & \multirow{3}{*}{ Outside } & \multirow{3}{*}{$6 / 5 / 2009$} & 1 & & & & 32 & 1 & & & & & & & & 4 & 37 & 3 & 0.46 \\
\hline & & & 2 & & & & 17 & & & & & & & & & & 17 & 1 & 0.00 \\
\hline & & & 3 & & & & 16 & 2 & & & & & & & & & 18 & 2 & 0.35 \\
\hline Sum & & & & 589 & 1 & 2 & 8732 & 112 & 69 & 37 & 45 & 34 & 20 & 6 & 8 & 11 & 9666 & 17 & 0.46 \\
\hline$\%$ Total & & & & 6.09 & 0.01 & 0.02 & 90.34 & 1.16 & 0.71 & 0.38 & 0.47 & 0.35 & 0.21 & 0.06 & 0.08 & 0.11 & 100.00 & & \\
\hline
\end{tabular}



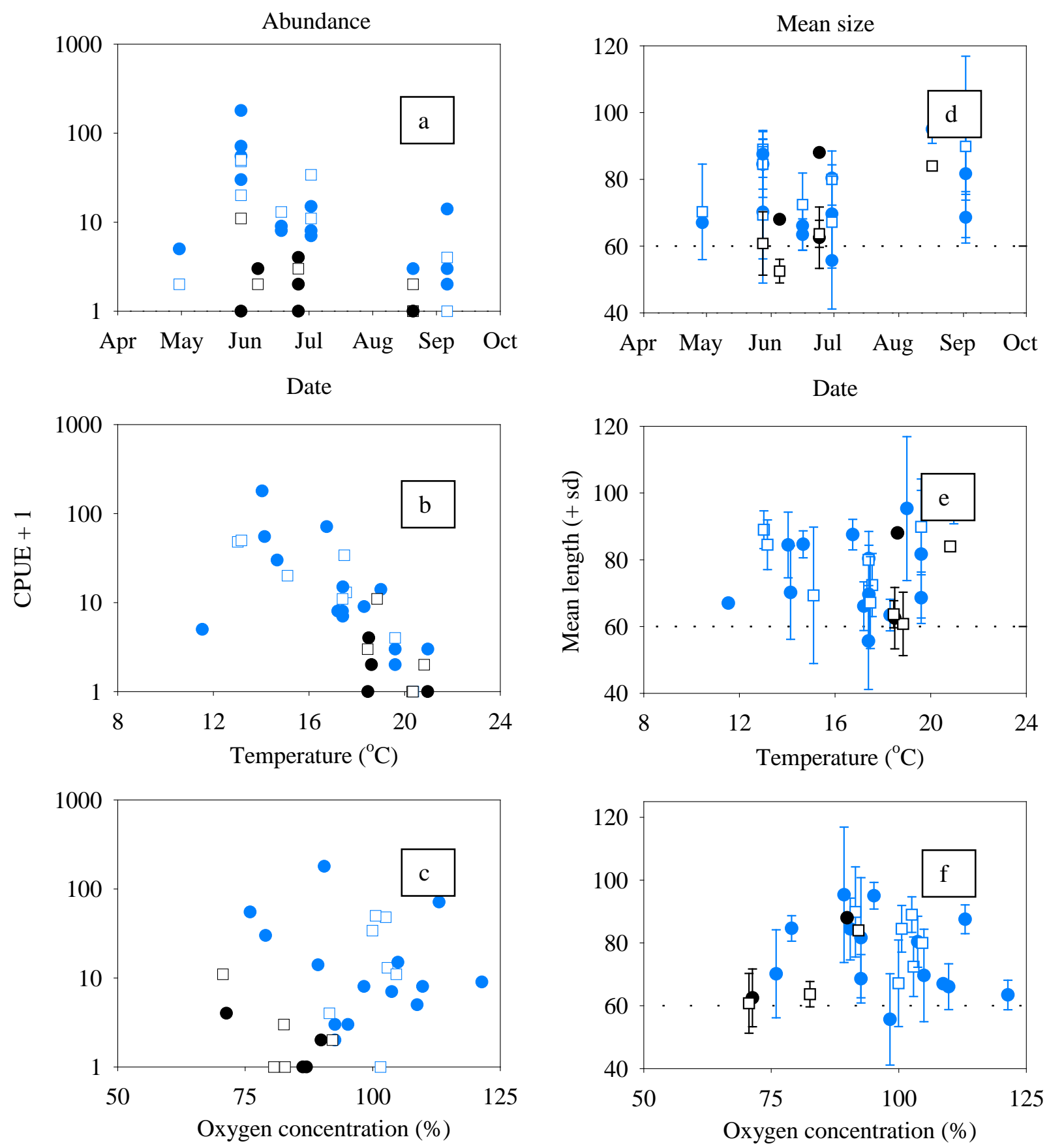

Figure C.4. Chinook Salmon CPUE Relative to Sample Site (left column) and Mean Size (right column) as Functions of Date (A and D), Temperature (B and E), and Dissolved Oxygen Concentration (C and $\mathrm{F}$ )

Optimal temperatures for salmon growth are in the 16 to $19^{\circ} \mathrm{C}$ range, while temperatures peaked between 20 and $22^{\circ} \mathrm{C}$ (Figure C.5a). Dissolved oxygen values ranged from $70 \%$ to supersaturated (Figure C.5c), and there was no obvious abundance pattern in relation to dissolved oxygen (Figure C.4c). Values in this range are not limiting to salmonids. Chinook abundances were much lower in the Youngs Bay tributaries than in the wetlands in the main stem (Figure C.4a). This is probably a consequence of 
the greatly reduced salmon production in the Youngs Bay basin. However, the Youngs Bay wetlands were also estuarine, and salinity values increased over the summer, reaching a maximum of 4.8 practical salinity units during our August sample (Figure C.5b). Salinity may have induced smoltification and enhanced migration to the sea.

We were especially interested in comparing salmon use of restoring wetlands. Chinook salmon were found in every restoring wetland we sampled (Table C.7). Size-frequency histograms were similar between inside and outside restoring wetland sites (Figure C.6). Overall frequency of occurrence was $66.7 \%$ of samples taken inside restoring wetlands versus $69.7 \%$ outside the wetlands. There was a significant relation on the log CPUE between inside and outside samples $\left(r^{2}{ }_{\text {adj }}=0.52, p=0.002, n=14\right.$; Figure C.7a). Temperatures between inside and outside site pairs were highly correlated $\left(\mathrm{r}^{2}{ }_{\text {adj }}=0.96\right.$, $\mathrm{p}<0.001, \mathrm{n}=12$; Figure C.7b), and dissolved oxygen levels were weakly but significantly related $\left(\mathrm{r}^{2}\right.$ adj $=$ 0.39, p-0.022, n=11; Figure C.7c). These wetlands are under tidal influence, and circulation likely maintains similar water quality between inside and outside sites.

Chinook salmon size ranged from 37 to $115 \mathrm{~mm}$. Based on size-at-date, all the fish were subyearling migrants. There were no strong trends of mean size by date (Figure C.4d), temperature (Figure C.4e), or oxygen concentration (Figure C.4f). The mean percent of measured fish that were fry was similar between inside and outside sites (18.0 versus $22.8 \%$, respectively). These unclipped small fish are likely progeny of wild spawners. Equal mean proportions of salmon were adipose-fin-clipped inside and outside of the wetland sites (58.9\%), indicating hatchery origin. We thus conclude that both wild and hatchery-reared Chinook salmon are using the range of restoring wetlands we sampled. Finally, diets were similar between sites, with insects and corophium amphipods dominating the IRI. However, a comparatively large proportion of ingested material was too digested for relative identification (Figure C.8). 

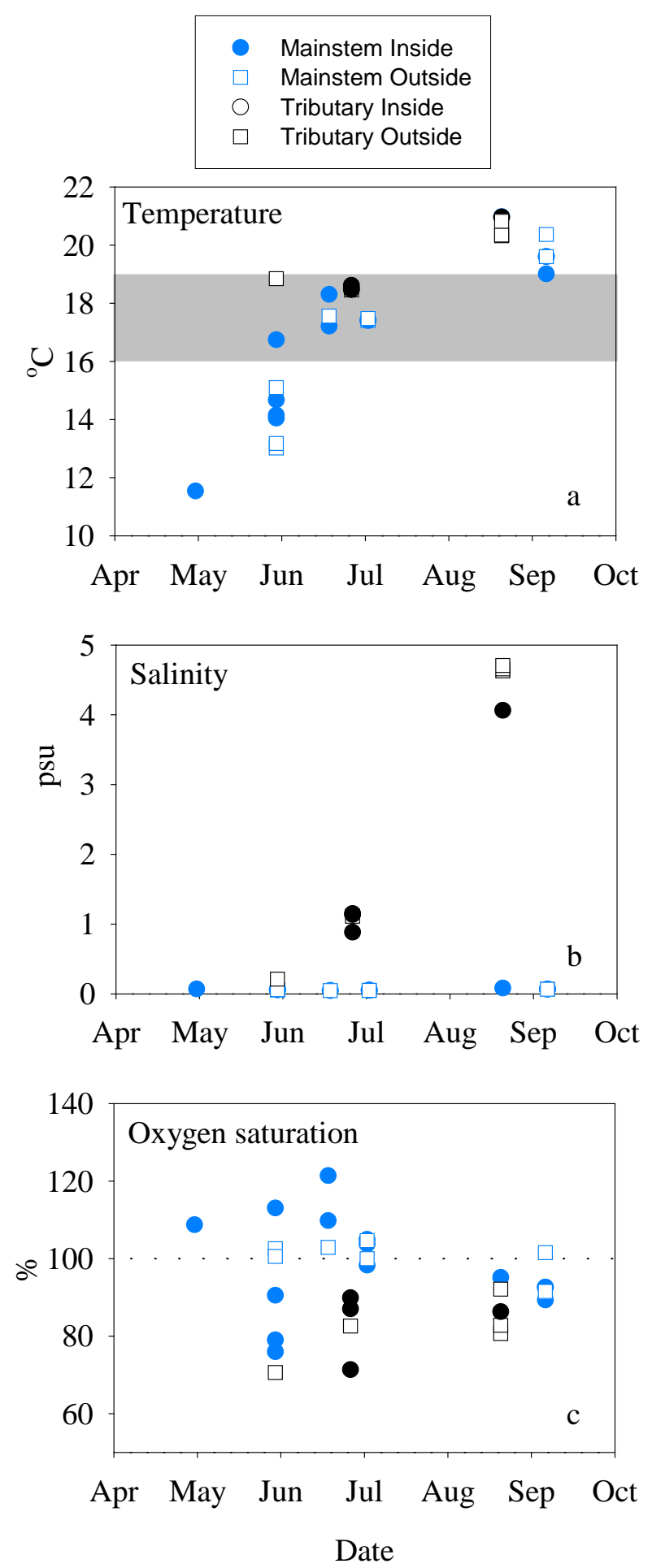

Figure C.5. Water-Quality Parameters Measured Inside and Outside Restoring Wetland Sites.

A) temperature, with the $16^{\circ} \mathrm{C}$ to $19^{\circ} \mathrm{C}$ critical temperature levels highlighted, B) salinity, and $\mathrm{C}$ ) dissolved oxygen concentration. 

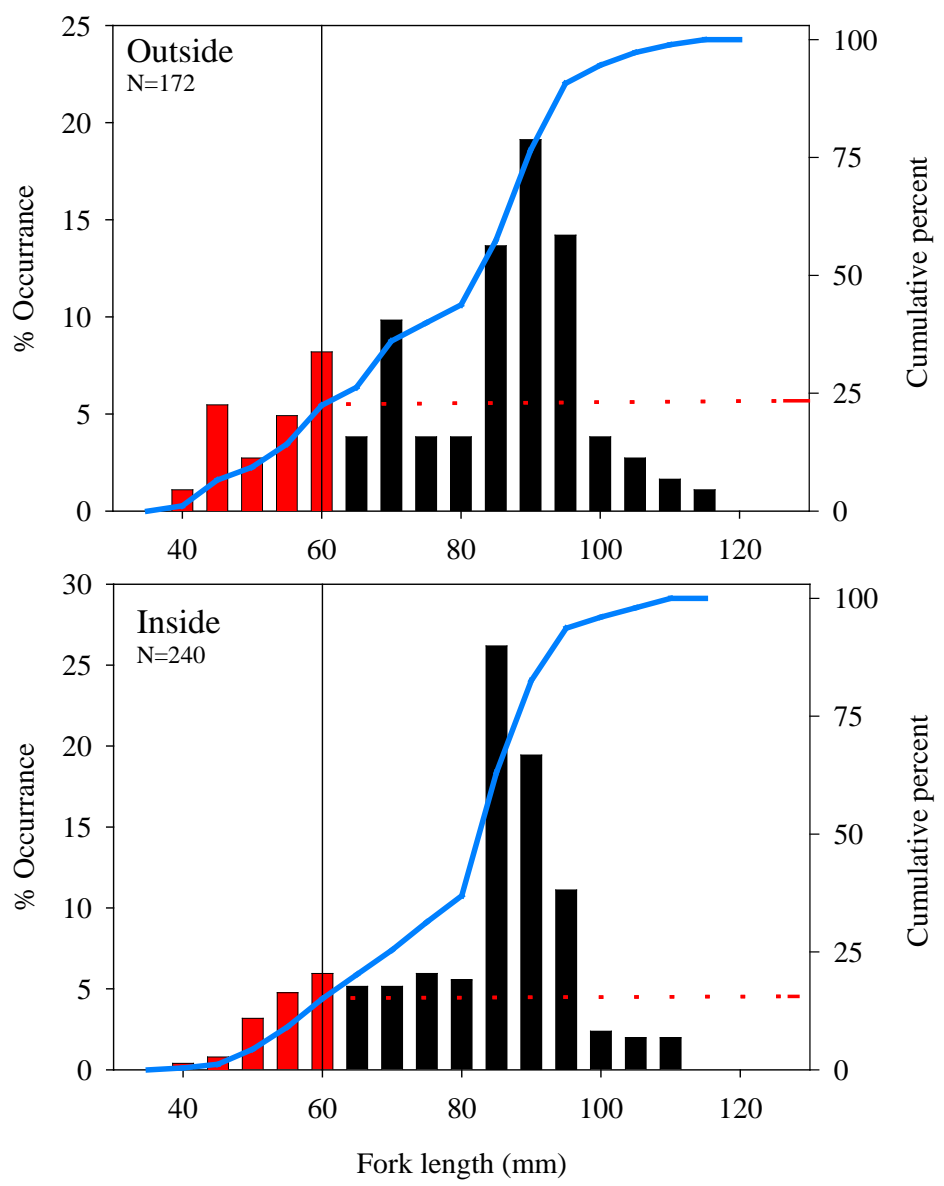

Figure C.6. Chinook Salmon Size-Frequency Distributions from Outside and Inside Wetland Sites. Fry sized salmon are shaded red. 

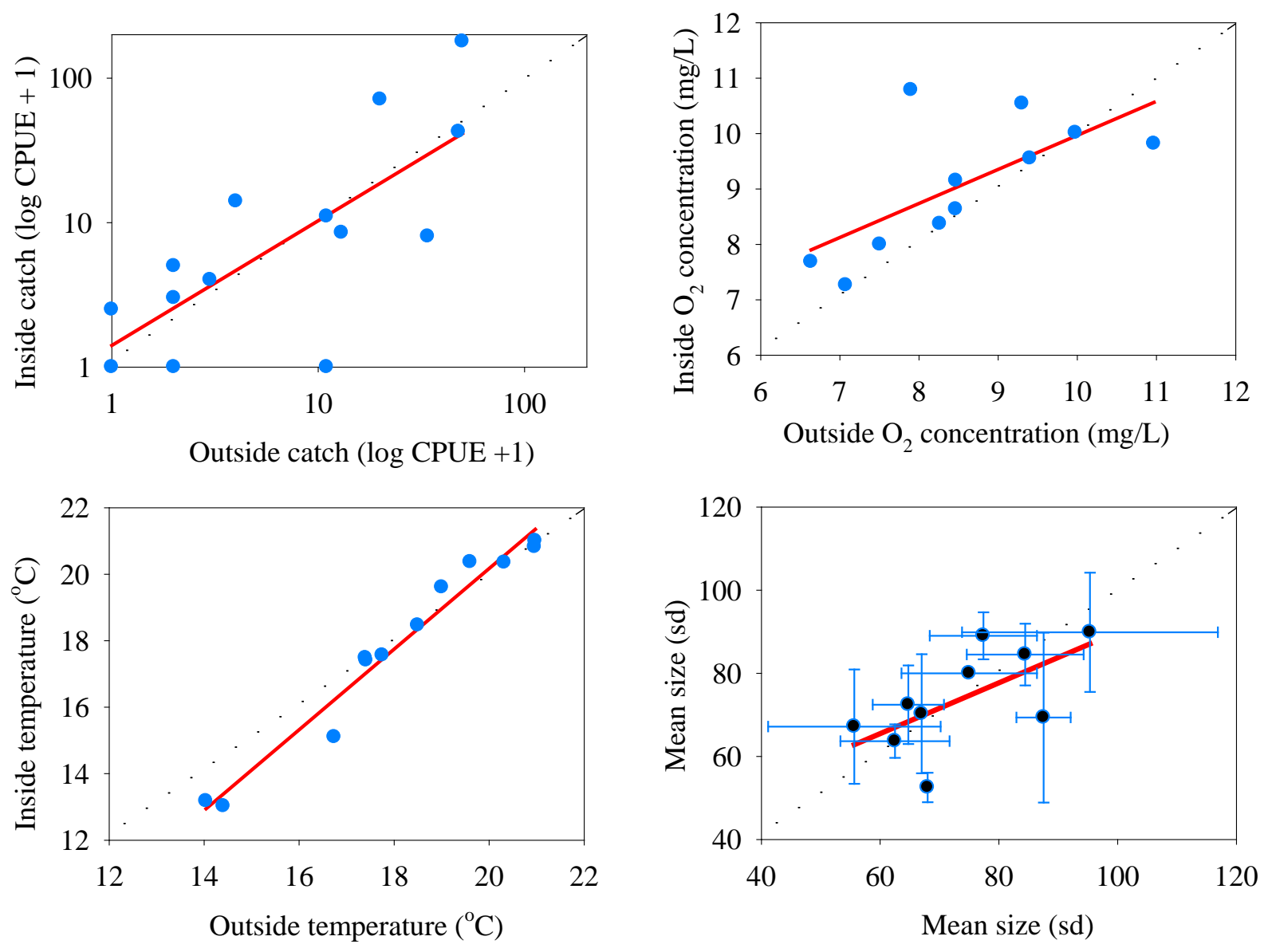

Figure C.7. Comparisons Inside and Outside of Breaches. A) CPUE; B) temperature; C) oxygen; D) mean size. 


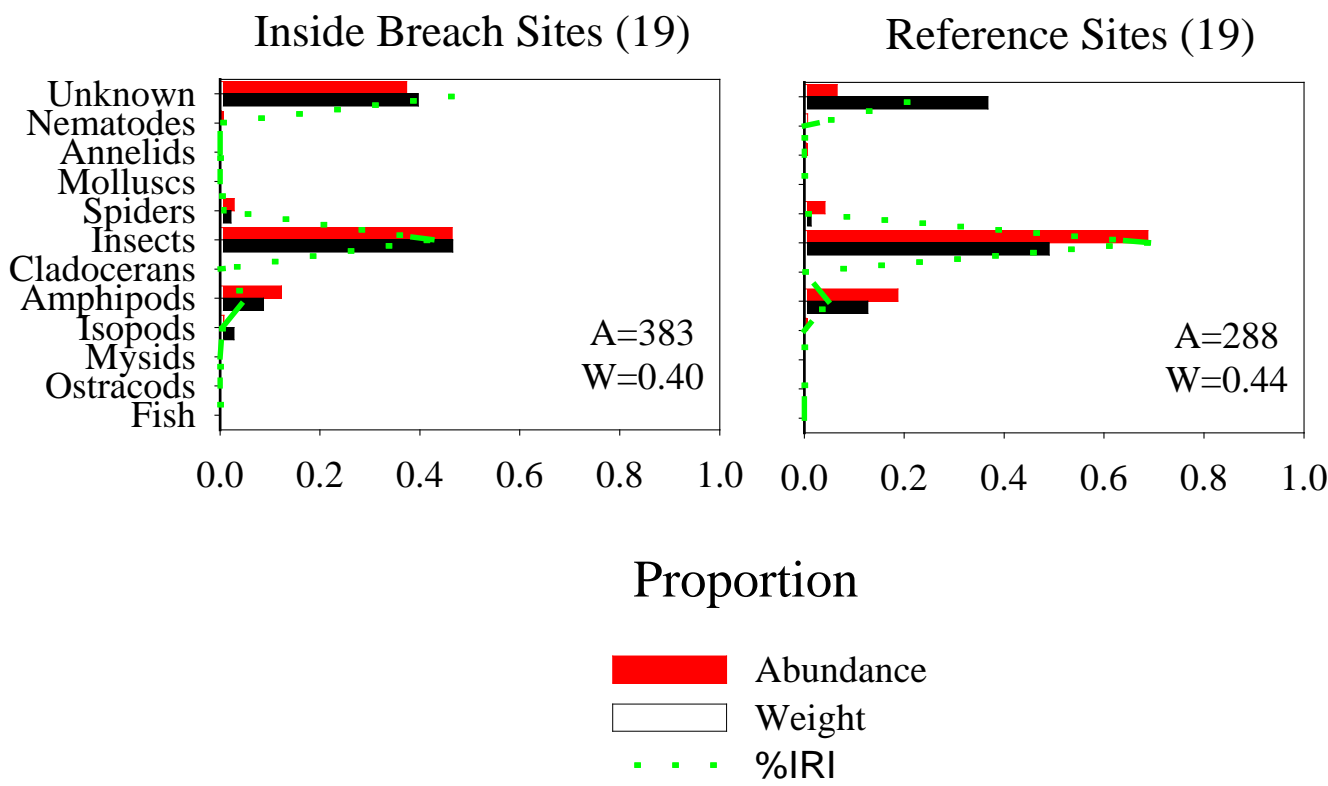

Figure C.8. Diets of Chinook Salmon Inside and Outside of the Wetland Sites

\section{C.4 Summary of Key Findings}

We do not purport to have analyzed functional equivalency, because we used relatively rapid field assessment methods to evaluate abiotic and biotic features of the study sites and compare them with a suite of reference sites. Nevertheless, any description of a restoration trajectory of necessity will be incomplete with respect to the number of metrics sampled or sampling frequency (SER 2004). Key findings thus far are as follows:

- None of the sites exceeded 3 m NAVD88 in elevation, most plant species elevations were between $1 \mathrm{~m}$ NAVD88 and $3 \mathrm{~m}$ NAVD88, and in general the created sites showed the narrowest elevation ranges $(<1 \mathrm{~m}$ each).

- Myosotis species had the highest relative dominance at two created and one historically breached site; Carex lyngbyei and Carex obnupta, respectively, had the highest relative dominance at two other historically breached sites; the third created site was co-dominated by Eleocharis palustris and Phalaris arundinacea; the final historically breached site was dominated by Schoenoplectus tabernaemontani.

- Invasive plant species were present at all sites, and included Iris pseudacorus, Lythrum salicaria, Myosotis species, and Phalaris arundinacea.

- Channel morphology was unusual at two of the three created sites sampled, with limited depths and/or bank development. 
- Fish CPUE, diversity, and species richness at restoration and reference sites were all relatively low compared with similar samples acquired from Columbia River main stem sites, but values were similar between samples taken inside and outside of breached or created areas.

- Chinook salmon were the only abundant salmonid sampled, partially because of the life histories of these and other salmonid species. Chinook were present at all historically breached and created sites sampled, and Chinook salmon abundance peaked in June and decreased with increasing temperature. Chinook salmon size ranged from 37 to $115 \mathrm{~mm}$ and overall frequency of occurrence was $66.7 \%$ of samples taken inside restoring wetlands versus $69.7 \%$ outside the wetlands.

- Diets were similar between sites, with insects and corophium amphipods dominating the IRI.

- As discussed below, even the large existing suite of reference sites is not big enough to provide a suite of suitable sites for each project as envisioned by Diefenderfer et al. (In Press), and in some cases not even one site.

There were both spatial and temporal limitations on the selected set of sites. In the planning stages of this study, we had conceived of an evenly spaced time series of like breaches in like environments, but our reconnaissance survey showed that such a series did not exist. Furthermore, we had hoped to apply the control chart method to compare each single breached site with a suite of reference sites (Diefenderfer et al. In Press), but we found that even with a set of 44 reference sites throughout the estuary it was difficult to find even one reference site for each restoration site that was reasonably similar in terms of vertical elevation, hydrologic regime, distance from the main stem river, plant community, and channel network. Thus, our study is necessarily descriptive rather than a rigorous trends analysis. Temporal analyses also are somewhat confounded by the fact that it was not always possible to determine the year of historical activities, even using aerial photo interpretation (Table C.2).

Of the 235-km tidal portion of the LCRE, all of the sites identified fell below rkm 146. Thus, while both tidal freshwater and brackish areas are included in this study, river-flow-dominated portions of the LCRE are less well represented than areas where the hydrograph is dominated by the tides. The land cover at all seven historical sites is predominantly emergent marsh, so the swamps of the LCRE are also not well represented in this study. This is because it would not be expected that areas breached within the past 50 years could have developed substantial forest cover, because the subsidence of land surface elevation behind dikes in this region means that after dike breaching, flooding occurs too frequently for swamps, which occupy the higher locations on the elevation gradient in the LCRE (Fox et al. 1984).

\section{C.5 References}

Arthington, AH, SE Bunn, NL Poff, and RJ Naiman. 2006. "The Challenge of Providing Environmental Flow Rules to Sustain River Ecosystems.” Ecological Applications 16:1311-18.

Borde, AB, HL Diefenderfer, SA Zimmerman, NK Sather, and RM Thom. 2009. Lower Columbia River and Estuary Restoration Reference Site Study 2008 Report. PNWD-4133, prepared by the Battelle Marine Sciences Laboratory, Sequim, Washington, for the Lower Columbia River Estuary Partnership, Portland, Oregon. 
Bottom, DL, CA Simenstad, J Burke, AM Baptista, DA Jay, KK Jones, E Casillas, and MH Schiewe. 2005. Salmon at River's End: The Role of the Estuary in the Decline and Recovery of Columbia River Salmon. National Oceanic and Atmospheric Administration (NOAA) Technical Memorandum. NMFS-NWFSC-68, NOAA National Marine Fisheries Service, Seattle, Washington.

Bunn, S and A Arthington. 2002. "Basic Principles and Ecological Consequences of Altered Flow Regimes for Aquatic Biodiversity.” Environmental Management 30:492-507.

Christy, JA and JA Putera. 1992. Lower Columbia River Natural Area Inventory. The Nature Conservancy, Seattle, Washington.

Clarain, EJ, Jr., RA Cole, RJ Diaz, AW Ford, RT Huffman, LJ Hunt, and BR Wells. 1978. Habitat Development Field Investigations at Miller Sands Marsh and Upland Habitat Development Site, Columbia River, Oregon: Summary report. Technical Report D-77-38, U.S. Army Corps of Engineers Waterways Experiment Station, Environmental Laboratory, Vicksburg, Mississippi.

Diefenderfer, HL, AM Coleman, AB Borde, and IA Sinks. 2008. "Hydraulic Geometry and Microtopography of Tidal Freshwater Forested Wetlands and Implications for Restoration, Columbia River, U.S.A.” Ecohydrology and Hydrobiology 8(2-4):339-361. doi: 10.2478/v10104-009-0027-7

Diefenderfer, HL and DR Montgomery. 2009. "Pool spacing, channel morphology, and the restoration of tidal forested wetlands of the Columbia River, U.S.A.” Restoration Ecology 17:158-168.

Diefenderfer, HL, RM Thom, and KD Hofseth. 2005. "A framework for risk analysis for ecological restoration projects in the U.S. Army Corps of Engineers.” Pages 57-105 in RJF Bruins and MT Heberling (eds.) Economics and Ecological Risk Assessment: Applications to Watershed Management. CRC Press, Boca Raton, Florida.

Diefenderfer, HL, RM Thom, GE Johnson, JR Skalski, KA Vogt, BD Ebberts, GC Roegner, and EM Dawley. In Press. "A levels-of-evidence approach for assessing cumulative ecosystem response to estuary and river restoration programs.” Ecological Restoration 28.

Dynesius, M and C Nilsson. 1994. "Fragmentation and flow regulation of river systems in the northern third of the world.” Science 266:753-762.

Endangered Species Act. 16 USC 1531 et seq.

Fox, DS, S Bell, W Nehlsen, and J Damron. 1984. The Columbia River Estuary: Atlas of Physical and Biological Characteristics. Columbia River Estuary Data Development Program, Astoria, Oregon.

Hinton, S and R Emmett. 2000. Biological Surveys of the Trestle Bay Enhancement Project 1994, 19961997. National Oceanic and Atmospheric Administration Technical Memorandum NMFSNWFSC-39, final report by the National Marine Fisheries Service, Seattle, Washington.

Junk, WJ and KM Wantzen. 2003. The Flood Pulse Concept: New Aspects, Approaches and Applications - an Update. Technical, Max-Planck-Institute for Limnology, Plön, Germany. 
Kareiva, P, M Marvier, and M McClure. 2000. "Recovery and management options for spring/summer Chinook salmon in the Columbia River basin.” Science 290:977-979.

Kukulka, T and DA Jay. 2003a. "Impacts of Columbia River discharge on salmonid habitat: 1. a nonstationary fluvial model.” Journal of Geophysical Research 108:3293, doi:10.1029/2002JC001382.

Kukulka, T and DA Jay. 2003b. "Impacts of Columbia River discharge on salmonid habitat: 2. changes in shallow-water habitat.” Journal of Geophysical Research 108:3294, doi:10.1029/2003JC001829.

Levings, CD. 1994. "Feeding behavior of juvenile salmon and significance of habitat during estuary and early sea phase.” Nordic J. Freshw. Res. 69: 7-16.

Levings, CD, K Conlin, B Raymond. 1991. "Intertidal habitats used by juvenile Chinook salmon (Oncorhynchus tshawytscha) rearing in the North Arm of the Fraser River estuary.” Mar. Pollution Bull. 22: 20-26.

Levy, DA and TG Northcote. 1982. "Juvenile salmon residency in a marsh area of the Fraser River estuary.” Can. J. Fish. Aquat. Sci. 39: 270-276.

Lotze, HK, HS Lenihan, BJ Bourque, RH Bradbury, RG Cooke, MC Kay, SM Kidwell, MX Kirby, CH Peterson, and JBC Jackson. 2006. "Depletion, Degradation, and Recovery Potential of Estuaries and Coastal Seas.” Science 312:1806-09.

Lytle, DA and NL Poff. 2004. “Adaptation to Natural Flow Regimes.” Trends in Ecology \& Evolution 19:94-100.

Martin, I. 1997. Beach of Heaven: A History of Wahkiakum County. Washington State University Press, Pullman, Washington.

Middleton, BA. 2002. “The Flood Pulse Concept in Wetland Restoration.” In Flood Pulsing in Wetlands: Restoring the Natural Hydrological Balance. John Wiley \& Sons, New York, New York.

Naiman, RJ and MG Turner. 2000. “A Future Perspective on North America's Freshwater Ecosystems.” Ecological Applications 10:958-70.

Nilsson, C, R Jansson, B Malmqvist, and RJ Naiman. 2007. "Restoring riverine landscapes: the challenge of identifying priorities, reference states, and techniques.” Ecology and Society 12(1):16.

National Marine Fisheries Service (NMFS). 2008. Biological Opinion - Consultation on Remand for Operation of the Federal Columbia River Power System, 11 Bureau of Reclamation Projects in the Columbia Basin and ESA Section 10(a)(1)(A) Permit for Juvenile Fish Transportation Program. NMFS (National Oceanic and Atmospheric Administration Fisheries) - Northwest Region, Seattle, Washington. May 5, 2008.

Pinkas, L, MS Oliphant, and ILK Iverson. 1971. "Food habits of the albacore, bluefin, tuna and bonito in California waters.” California Fish and Game 152:1-105. 
Poff, NL, JD Allan, MB Bain, JR Karr, KL Prestegaard, BD Richter, RE Sparks, and JC Stromberg. 1997. "The natural flow regime: a paradigm for river conservation and restoration." BioScience 47:769-784.

Poff, NL, JD Allan, MA Palmer, DD Hart, BD Richter, AH Arthington, KH Rogers, JL Meyer, and JA Stanford. 2003. "River flows and water wars: emerging science for environmental decision making.” Frontiers in Ecology and the Environment 1:298-306.

Reimers, PE and RE Loeffel. 1967. "The length of residence of residence of juvenile fall Chinook salmon in selected Columbia River tributaries.” Res. Briefs, Fish Comm. Oreg. 13(1):5-19.

Rich, WH. 1920. "Early history and seaward migration of Chinook salmon in the Columbia and Sacramento Rivers.” U.S. Bur. Fish. Bull. 37:2-73.

Roegner, GC, EW Dawley, M Russell, A Whiting, DJ Teel. In Press. “Juvenile salmonid use of reconnected tidal freshwater wetlands in Grays River, lower Columbia Basin.” Transactions of the American Fisheries Society.

Roegner, GC, HL Diefenderfer, AB Borde, RM Thom, EM Dawley, AH Whiting, SA Zimmerman, and GE Johnson. 2009. Protocols for Monitoring Habitat Restoration Projects in the Lower Columbia River and Estuary. U.S. Department of Commerce, NOAA Technical Memo, NMFS-NWFSC-97, 63 pp. Seattle, Washington.

Seaburg, KG. 1957. “A stomach sampler for live fish.” Progressive Fish-Culturist 19:137-139.

Sidner, JK, MA Vinton, and LM Vigue. 2007. "The role of litter in the success of the invasive plant, reed canary (Phalaris arundinacea).” In Proceedings of the Joint Meeting of The Ecological Society of America and the Society for Ecological Restoration International, 4-10 August, San Jose, California.

Simenstad, CA and BE Feist. 1996. Restoration Potential of Diked Estuarine Wetlands: Inferring Fate and the Recovery Rate of Historically-Breached Sites. U.S. Environmental Protection Agency Office of Ecosystems \& Communities, EPA 910/R-96-005, July 1996, Seattle, Washington.

Simenstad, CA and RM Thom. 1996. "Functional equivalency trajectories of the restored Gog-Le-Hi-Te estuarine wetland.” Ecological Applications 6:38-56.

Society for Ecological Restoration International (SER) Science and Policy Working Group. 2004. The SER International Primer of Ecological Restoration. SER, Tucson, Arizona (www.ser.org).

Suding, KN and KL Gross. 2006. “The dynamic nature of ecological systems: Multiple states and restoration trajectories.” Pp. 190-209 in DA Falk, MA Palmer, and JB Zedler (eds.), Foundations of Restoration Ecology. Island Press, Washington, D.C.

Tharme, RE. 2003. “A Global Perspective on Environmental Flow Assessment: Emerging Trends in the Development and Application of Environmental Flow Methodologies for Rivers.” River Research and Applications 19:397-441. 
Thom, RM. 1997. "System-development matrix for adaptive management of coastal ecosystem restoration projects.” Ecological Engineering 8:219-232.

Thomas, DW. 1983. Changes in Columbia River Estuary Habitat Types over the Past Century. Columbia River Estuary Data Development Program, Columbia River Estuary Study Taskforce, Astoria, Oregon.

Tockner K and JA Stanford. 2002. "Riverine flood plains: present state and future trends.” Environmental Conservation 29:308-330.

Waples, RS. 1991. "Pacific salmon, Oncorhynchus spp., and the definition of 'species' under the Endangered Species Act.” U.S. Natl. Mar. Fish. Serv., Mar. Fish. Rev. 53(3):11-22.

Ward, JV, K Tockner, U Uehlinger, and F Malard. 2001. “Understanding Natural Patterns and Processes in River Corridors as the Basis for Effective River Restoration.” Regulated Rivers: Research and Management 17, pp. 311-323. 


\section{Distribution}

No. of

Hard Copies

\section{OFFSITE}

1 Blaine D. Ebberts

USACE Portland District

CENWP-PM-E

333 SW First Avenue

Portland, OR 97208-2946

20 Cynthia Studebaker USACE Portland District CENWP-PM-E

333 SW First Avenue

Portland, OR 97208-2946
No. of

Hard Copies

\section{ONSITE}

4 Marine Sciences Laboratory 1529 West Sequim Bay Road Sequim, WA 98382

Amy Borde Sequim Heida Diefenderfer Sequim Ron Thom Sequim Dana Woodruff Sequim

6 Battelle Portland Operations 620 SW 5th Avenue, Suite 810

Portland, OR 97204

Gary Johnson

BPO 


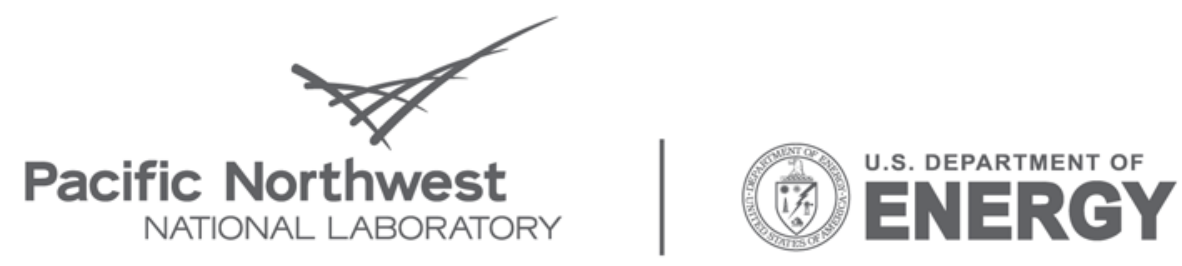

Proudly Operated by Battelle Since 1965

902 Battelle Boulevard

P.O. Box 999

Richland, WA 99352

1-888-375-PNNL (7665)

www.pnl.gov 